$$
\begin{aligned}
& \text { جامعة الأزهر } \\
& \text { كلية الدراسات الإسبلامية } \\
& \text { والعربية -بنبين - } \\
& \text { بالشرقبة }
\end{aligned}
$$

\title{
الدلالة اللغوية
}

\author{
بين \\ رقي القرآن
}

وشبهات المستشرقين
وجمالهم بإعجاز اللفظ القُرآني
(ألفاظ العلاقات الجنسية المحرمة نموذجًا)

드르르를

$$
\text { | (اعلاد }
$$

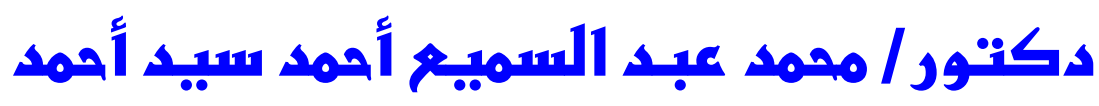

المدرس في قسم أصول اللغة جامعة الأزهر

$$
\text { (كلية الدراسات الإسلامية و العربية - بنين - بالثرقية) }
$$




\section{المقدمة}

الحمد لله رب العالمين أنزل على عبده الكتاب ، و جعله هُدى" وذكرى لأولي

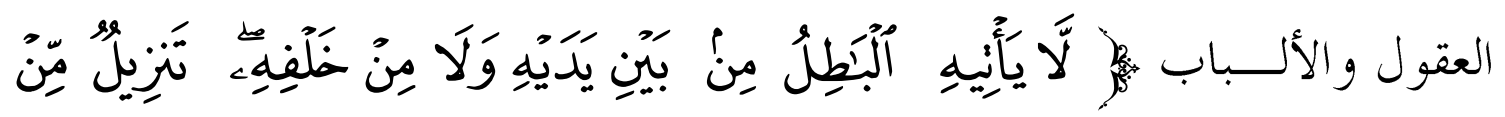

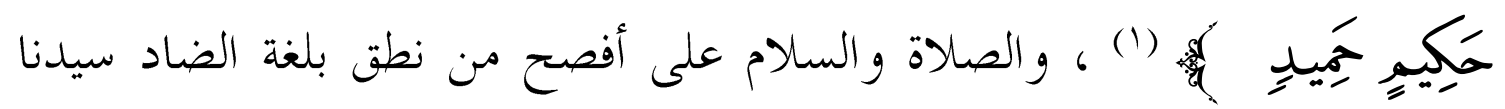

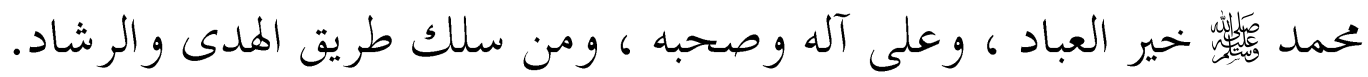

\section{وبعد}

فاللغة بالنسبة لكل أمَّة هي أداةُ تو اصُلٍ ، وطريقة تفكيرٍ ورمزٌ عزةٍ ، أما

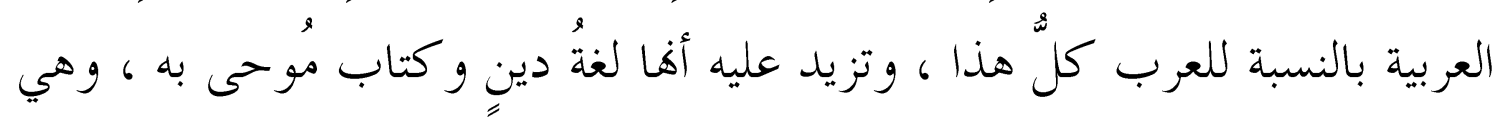

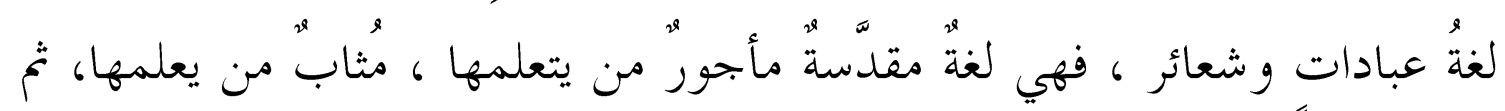
هي لغة محفوظة بحفظ الله للكتاب الذي نزل هما.

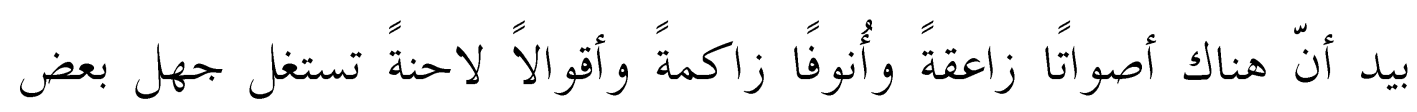
المسلمين بمعاني الألفاظ المستخدمة في القرآن واستخداماها في اللغة العربية ، بل و ابتعادهم عن اللغة العربية بشكل كبير ، وابتعادهم - أيضًا - عن فهم الدلالية القرآنية وما لها من أسرار لا يدر كها إلا من هداه الله للإسلام وشعَّ في قلبه نور الإيمان ، فراحوا يبثون شبهًا زائفةً حول ألفاظ القر آن ومعانيه .

فإلى كل غيورٍ على لغته ودينه ، وإلى كل من له دور في تعليم اللغة العربية ، عليه أن يقف أمام تلك الدعوات الإلحــــادية والتنصيرية ، التي يبثها أعداء الإسلام 
عبر مو اقع التواصل الاجتماعي من أمثال زكريا بطرس (')، وعبدالله الفادي (r)، وغيرهم ، إلى أن جاء يوسف القعيد(r) - عضو بحلس النواب - و تطاول على النص القرآني قائلاً : " لو طبقنا قانون خدش الحياء سنحاكم بعض آيات القرآن ، مثل ما جاء في سورة يوسف .."(ع) .

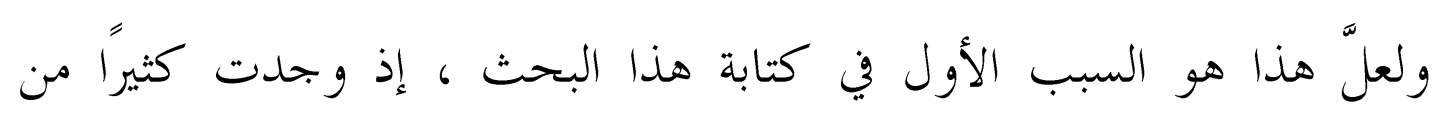
المثقفين - فضلاً عن ناقصي الثقافة - ينجرف وراء هذه الدعوات الإلحادية و التنصيرية ، وقد كان ذلك سببًا في محاولة إلحاد صديقٍ لي ( يعمل طبيبًا ) ، فمن أول يوٍٍ دخل وتفاعل مع تلك المواقع الإلحادية قام يشكك في القرآن وي لغته

(1) هو قمص قبطي أرثوذكسي ولد سنة ع19 (ام، ورسم في شبين الكوم ، ثم نقل إلى طنطا ، ثم

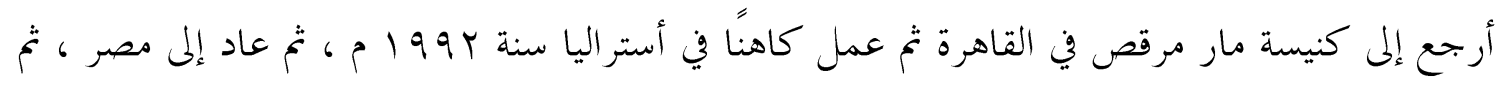

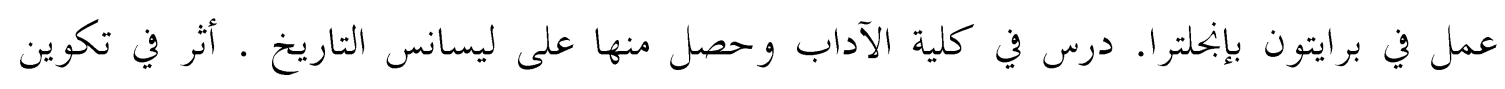

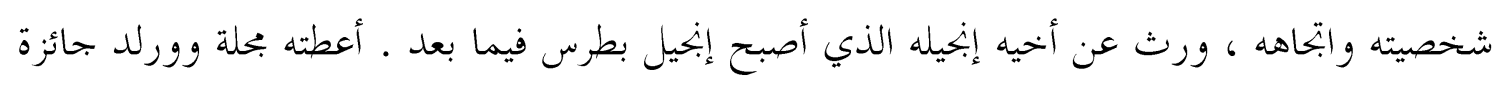

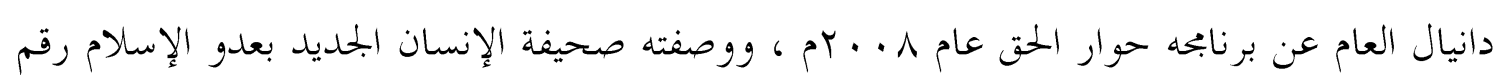

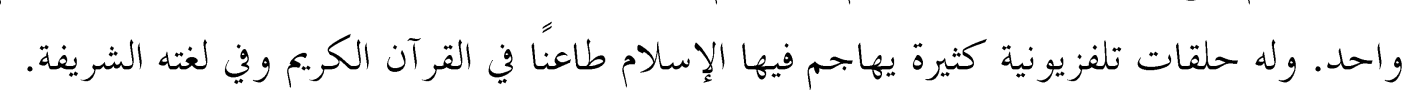

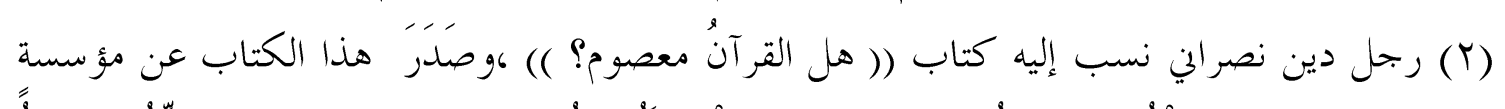

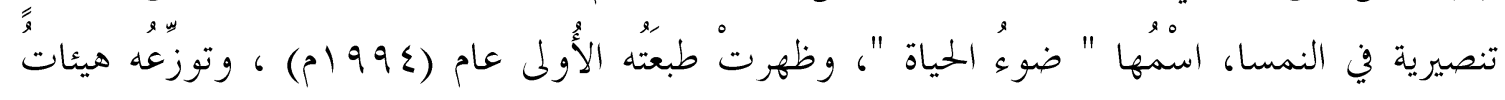

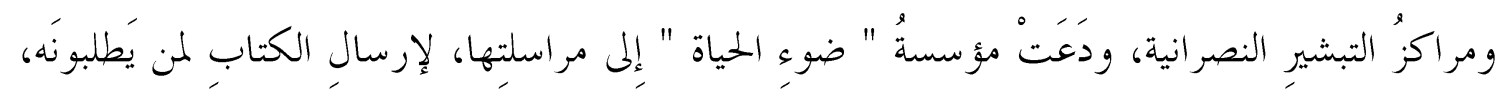

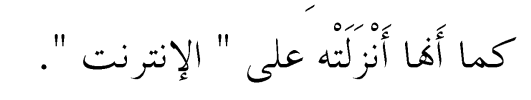

(r) كاتب وأديب وقصاص مصري معاصر ولد بمحافظة البحيرة ، اهتم بالتعبير عن المحيط القروي

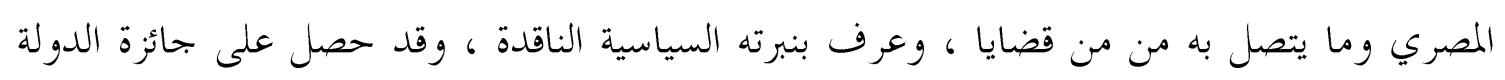
التقديرية في الآداب عام م م. بام.

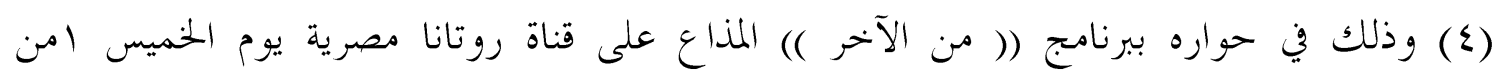
ديسمبر 7 • ب م. 
الشريفة ، وأخذ معى فترةً طويلةً لإقناعه ، وذبِّ تلك الشُّهُ عن فكره ، إلى أن

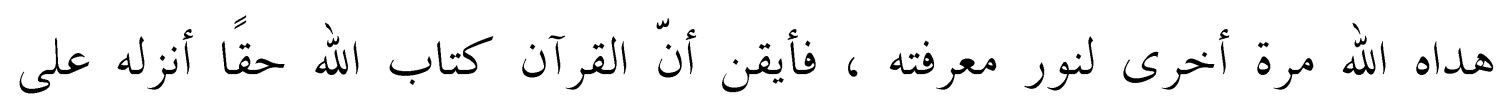
رسوله صدقًا.

ومن ثّ" أدركت أنّ البعد عن لغة القرآن وفهم دلالتها ، يجعل الإنسان المسلم

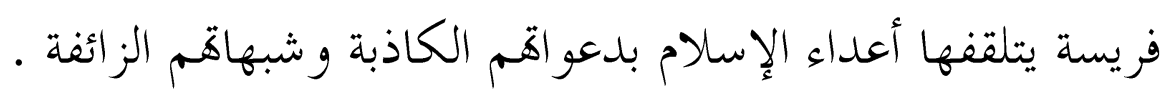

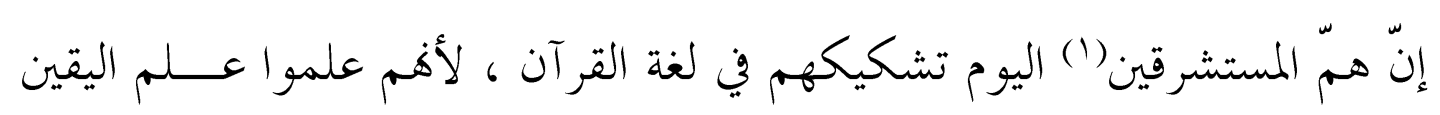

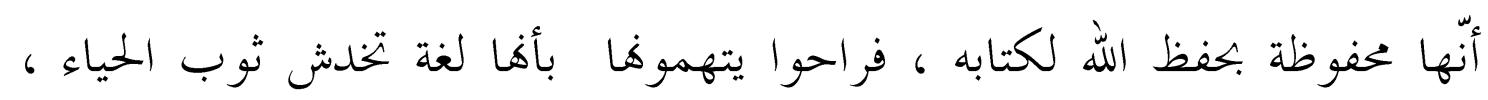

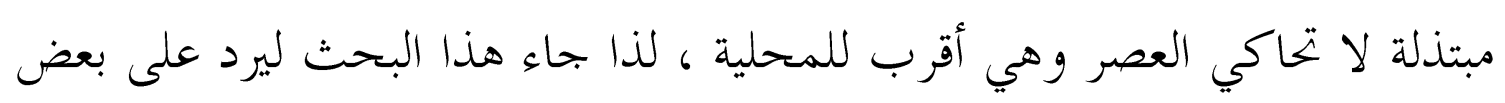

(1) الاستشراق : اتبحاه فكريّ ، يعني بدراسة حضارة الأمم الشرقية بصفة عامة وحضارة الإســلام

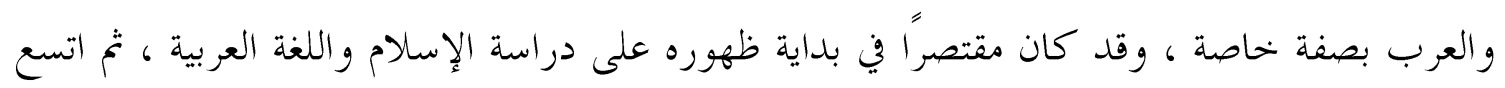

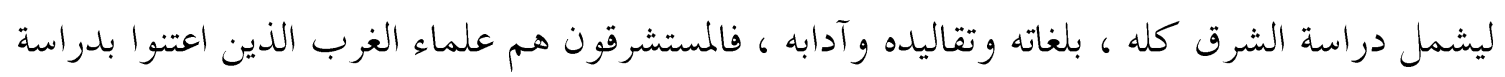

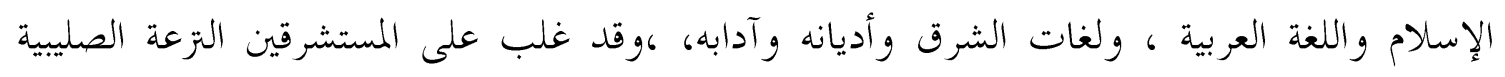

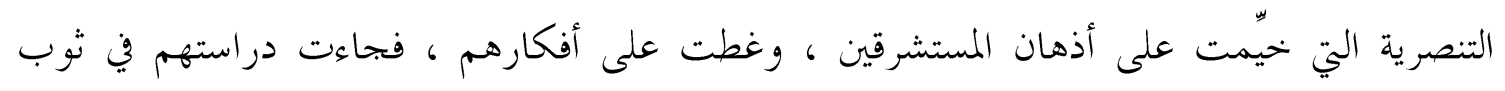

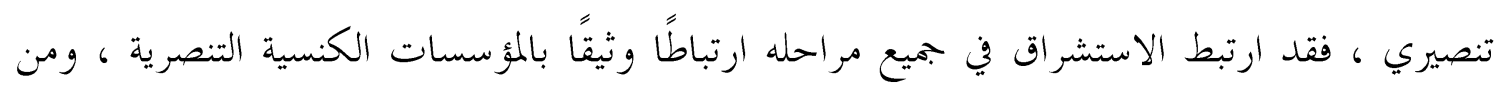

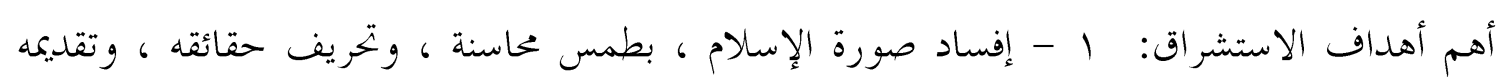

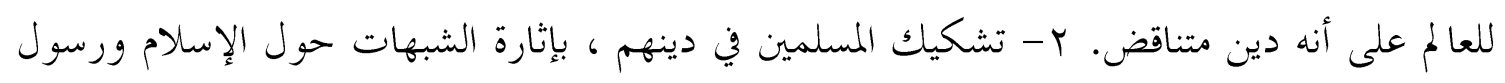

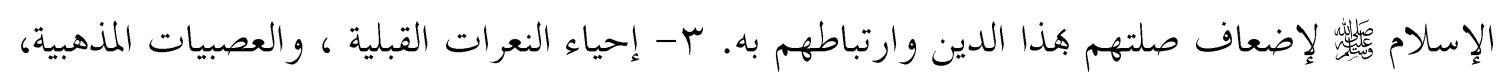

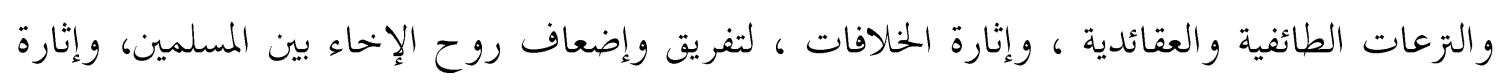

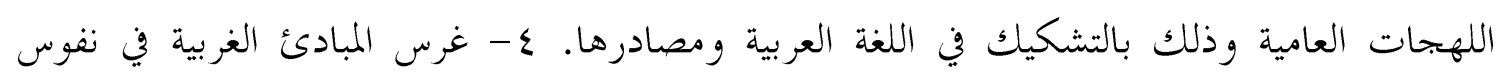

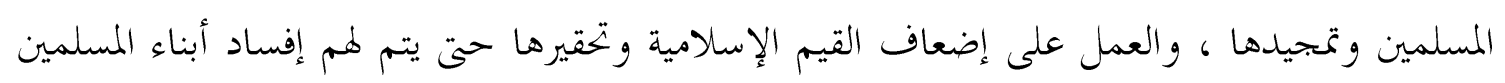

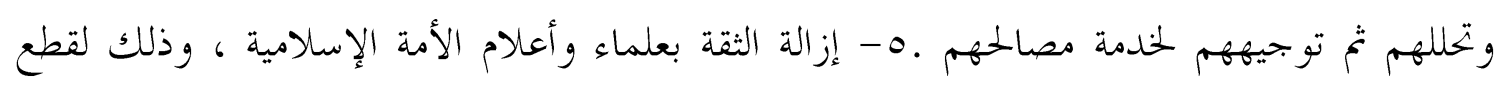
الصلة بين المسلمين وماضيهم ، وفي المقابل تمجيد الشخصيات الغربية وتعظيمها ليسهل التأثر والانقياد.

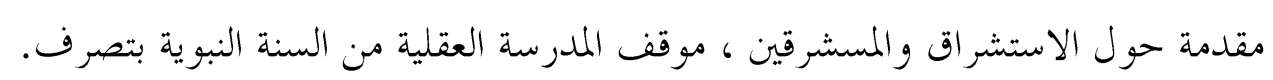


هذه الشبهات بإبراز ما في لغة القرآن من إعجاز وأسرار في اختيار المفردة القرآنية

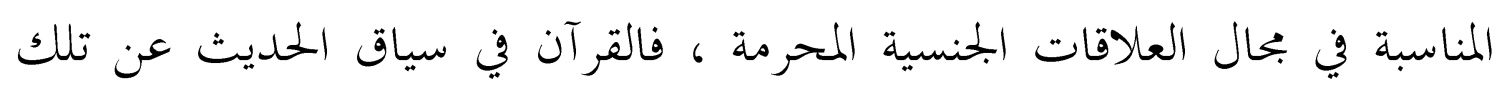

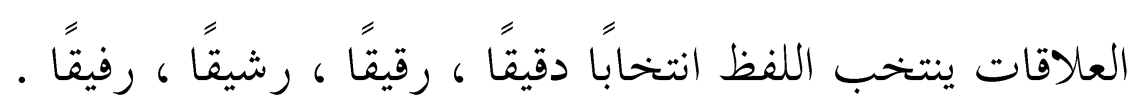

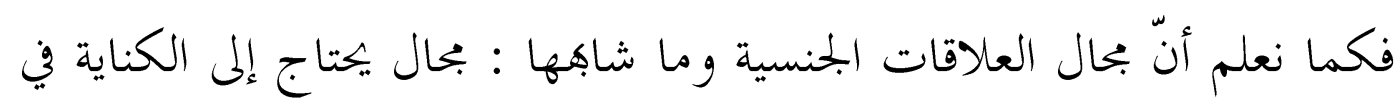

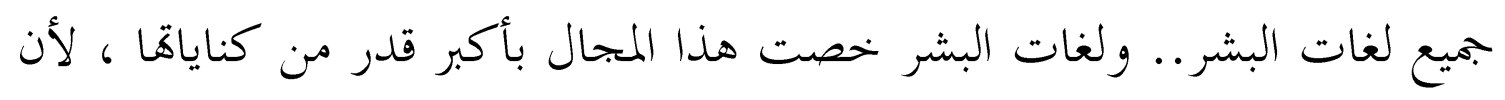

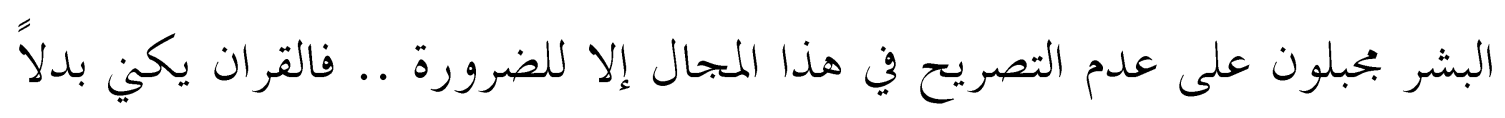

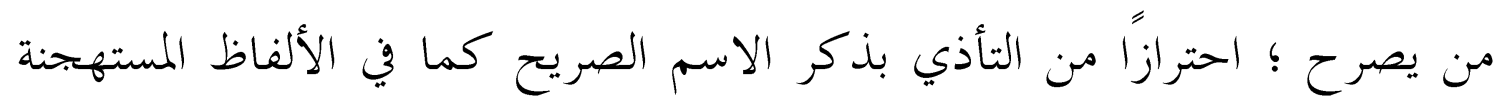

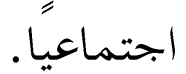

لذا نطلب من هؤلاء الذين يدَّعون أنّ في القرآن ألفاظًا خادشة للحياء ، وأنه يأمر بالعلاقات الجنسية غير المشروعة ، أن يذكروا لنا آية واحدة في القرآن الكريم

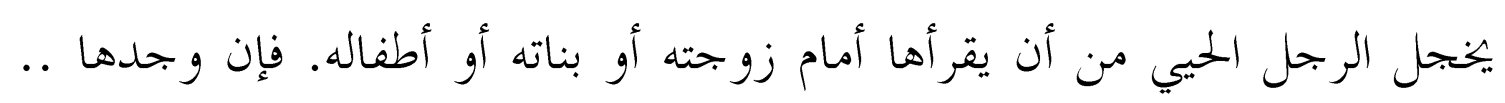

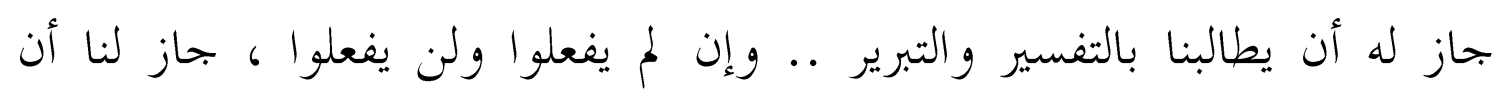

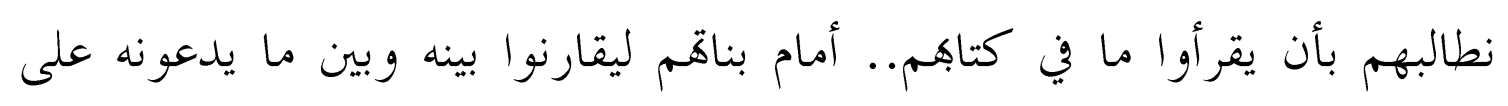

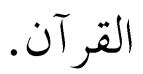

كما أنّ فكرة البحث في هذا الموضوع يدعمها واقع المسلمين اليوم ، و كأفم

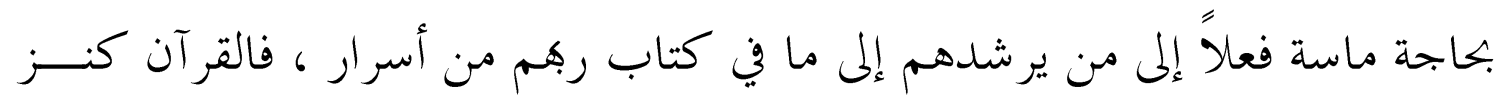

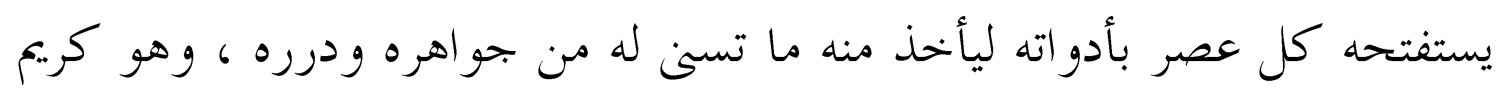


كلما استثير أعطى ، كما يقول سيدنا عبد الله بن مسعود رضى الله عنه : (ر من

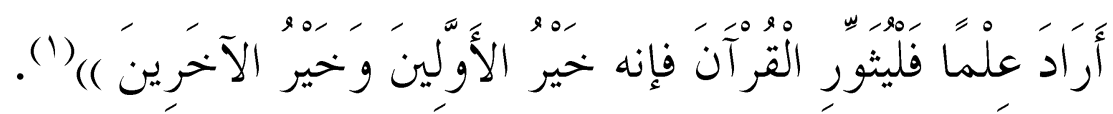

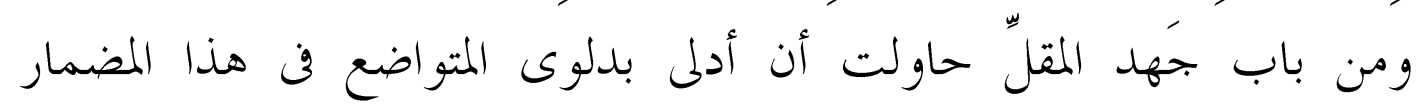
فأمضيت عدة ليالي بتتبع مواقع التنصير والإلحاد على الشبكة العنكبوتية - الانترنت - لأقف على تلك الشبهات التي يبثها المستشرقون حول لغة القرآن الكريم ، فتناولت شبه هؤلاء حول الألفاظ الدالة على العلاقات الجنسية المحرمة ، بالدراسة التأصيلية لبيان سر إعجازها . هذا وقد اعتمد البحث في هذه الدراسة الدلالية على المنهج الوصفى الذي يقوم على تقليم صورة جليلة أمام القارئ لجانب الإعجاز اللغوى في صوره المتعددة وأسراره العلمية الباهرة ، و كنت حريصًا على نقل القارئ إلى استنباط الأسرار الدلالية للمغردة القرآنية ، ومن هنا كان للمنهج الاستنتاجي مكان كبير بين ثنايا البحث .

كما اهتم البحث بناحية الاشتقاق اللغوي للألفاظ فذكرت أصولها الاشتقاقية ،

و الفروق الدلالية بينها ، و التناسب الدلالي في اختيار مفردة بعينها - دون غيرها في سياقها ـ و اعتمدت في هذا المنهج على أصول المصادر للأئمة اللغويين ، كما تضمنت هذه المصادر الرئيسية الأصول الأولى لكتب علوم القرآن الكريم وتفسيره، فرجعت إلى ما ذكره حذّاق المفسرين كالطبري و الزمخشري والقرطبي وغيرهم ممن

(1) أخر جه الإمام الطبراني في المعجم الكبير 9/ هـ ا 1 ، تحقيق: حمدي بن عبد المجيد ، الناشر مكتبة

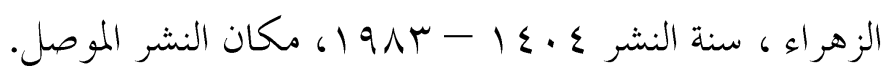


أسدوا خدمـات جليلة للقرآن الكريم وأرسوا دعائمه على أسس من الجلاء والوعي والوضوح.

وقد اقتت منهجية البحث أن تكون هذه الدراسة مقسمة إلى مقدمة وتمهيد وثمانية مباحث بياها كالآتي :

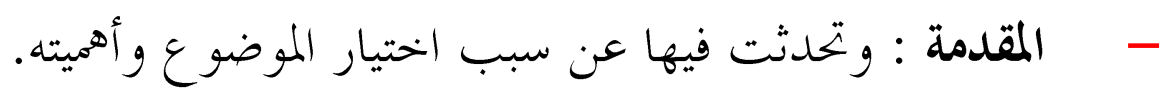

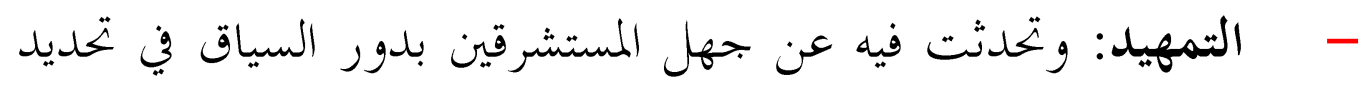
المعنى المراد من اللفظ. المبحث الأول : في دلالة لفظة : (( فاحشة )) .

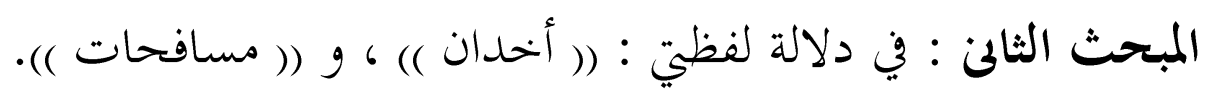

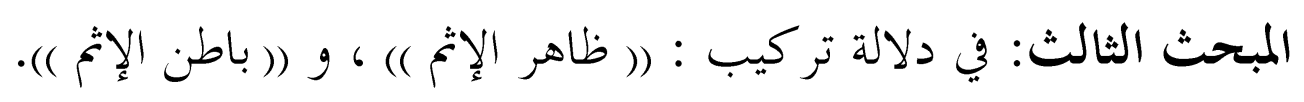
المبحث الر ابع : في دلالة لفظة : (( الهمّ )). المبحث الحخامس : في دلالة لفظة : (( السوء )) . المبحث السادس : في دلالة لفظة : (( زنا )). المبحث السابع : في دلالة لفظة : (( البغاء)). المبحث الثامن : في دلالة لفظة : (( البهتان )).

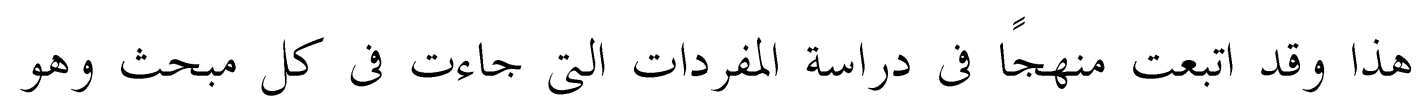
كالآتى : أولاً : اقتضى موضوع البحث اتباع المنهج الاستقرائي والاستباطي ، حيث

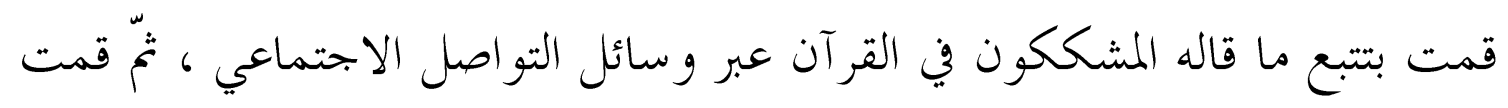

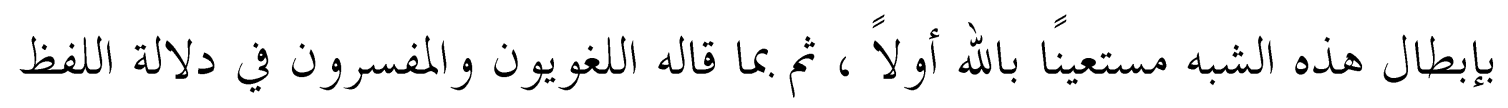
القرآن ، ثمّ قمت باستباط سرّ التعبير باللفظة المر ادة دون غيرها من أخواها. 
ثانيًا : التزمت بعزو الآيات لسورها ، و الأحاديث التي وردت في ثنايا البحث

$$
\text { بذكر كتب الحديث التي وردت فيها . }
$$

ثالثًا : قمت بترتيب المباحث حسب ورود ألفاظها في آيات القرآن الكريم ، ثم رتبت الآيات حسب ورودها في السور وترتيب السور على ترتيبها في المصحف

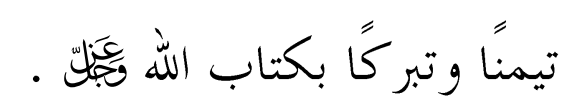

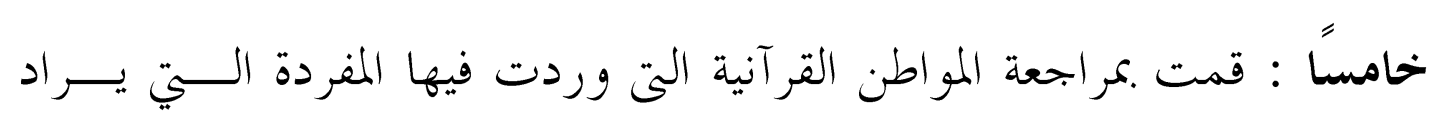
دراستها واستعمالاتحا ومعانيها ودلالتها . وقد اعتمد البحث على مصادر و مراجع كثيرة و منوعة فن اللغة و التفسير

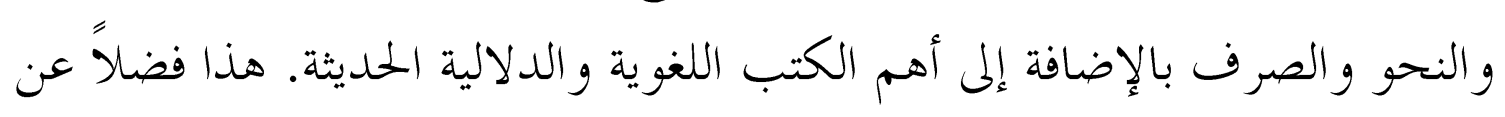
الكتب والأبحاث العلمية المختلفة . و كم كان هاجسى وقد اختر ت هذه الدراسة و خطو ت فيها تلك الخطى

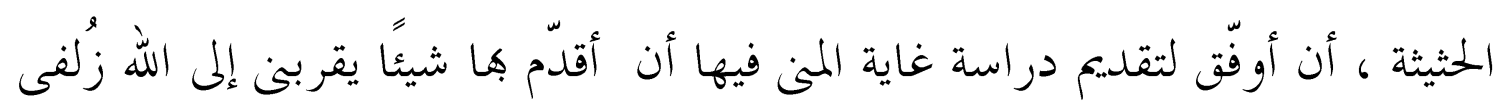

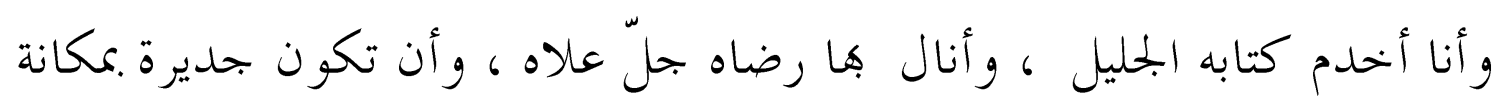

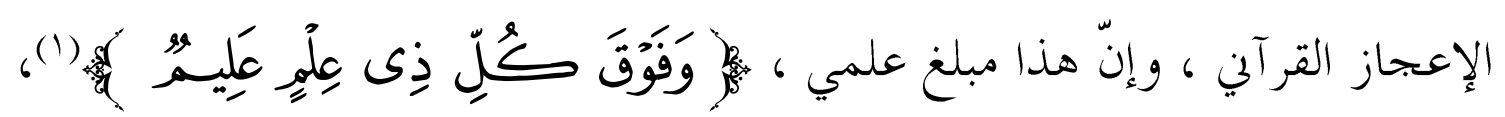

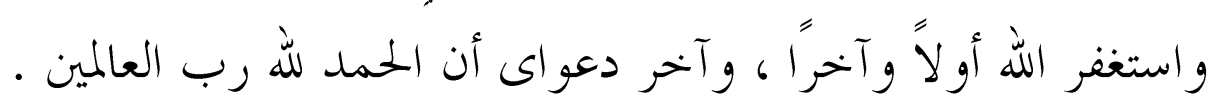

\section{المؤلف}




\section{ب.9011}

اعترض أعداء الإسلام على عدة كلمات وردت في القرآن الكريم ، في سياق

الحديث عن العلاقات الجنسية المحرمة كلفظة (الفحشاء - الزنا - البغاء -

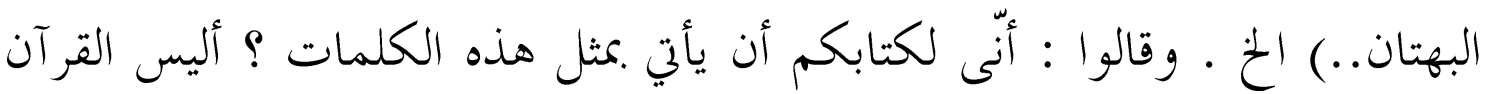

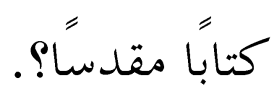

والحق أنّ هؤلاء جهلو ا بل بتحاهلو أنّ السياق يعد عاملاً حاسمًا في تحديد دلالة

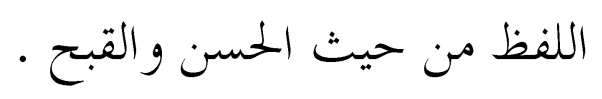

ويعنى بالسياق، النظم اللفظي للكلمة وموقعها من ذلك النظم ، الذى يشمل

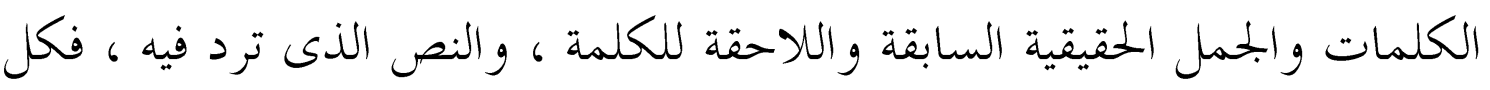

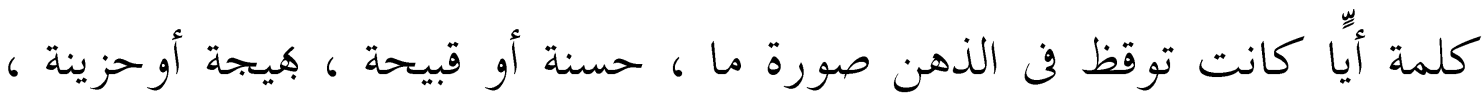

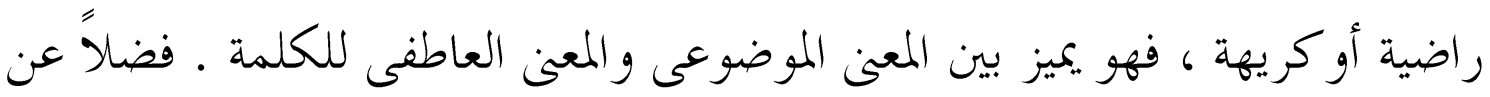

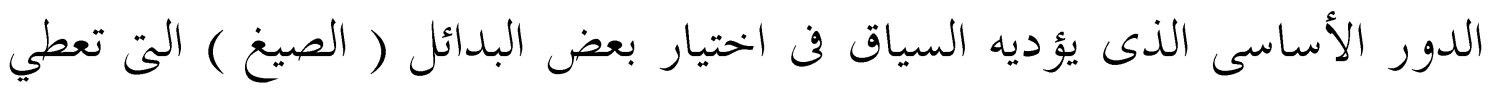
ملامح دلالية في السياق الواردة فيها.

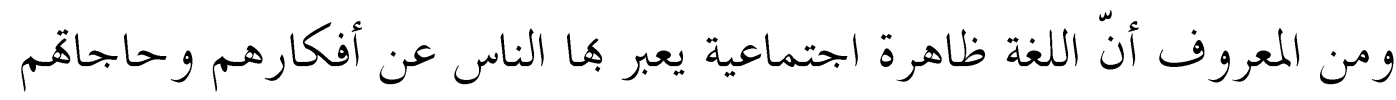

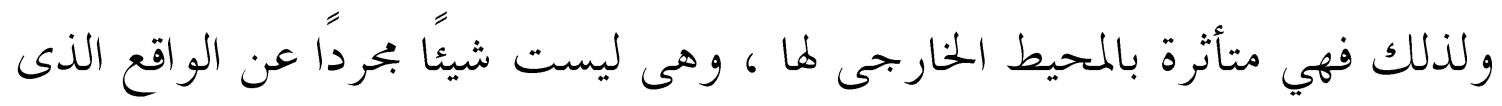

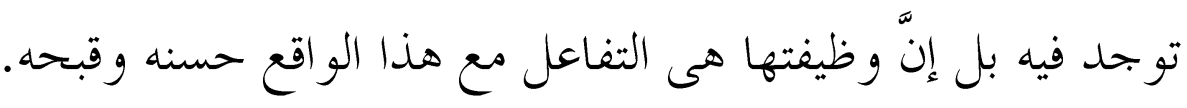


إذن فالكلمة لا قيمة لها في حالة إفرادها ، و إنّما يكون حُُنُها ورداءتها في

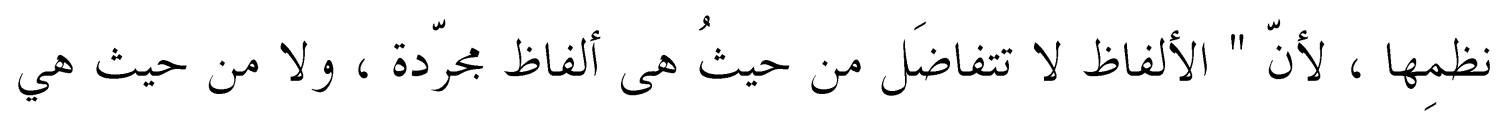

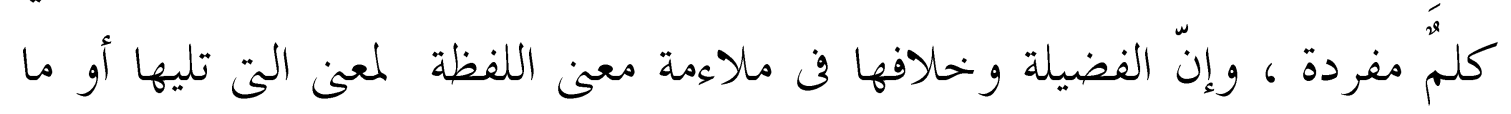

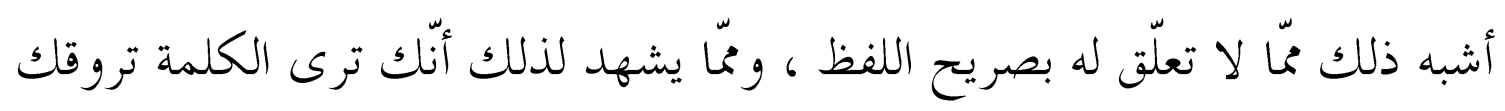

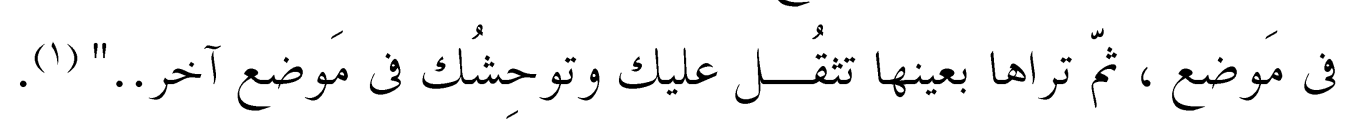
ومن ثم يتناول البحث الألفاظ الدالة على العلاقة الجنسية الغير مشروعة

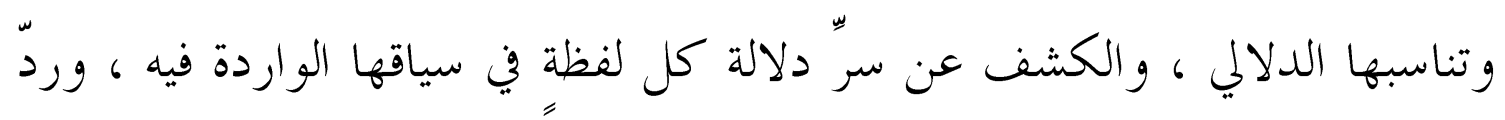
شبه المشككين حولها ، و الوقوف على أهم الفروق الدلالية بين تلك الألفاظ . 


\section{المبـث الأول : في دلالة لفظة : ( الفاحشة ) :}

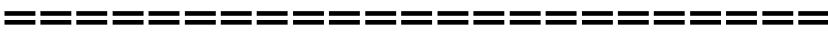

كلمة (( الفاحشة )) من الكلمات تدل على العلاقات الجنسية المحرمة (الزنا) .

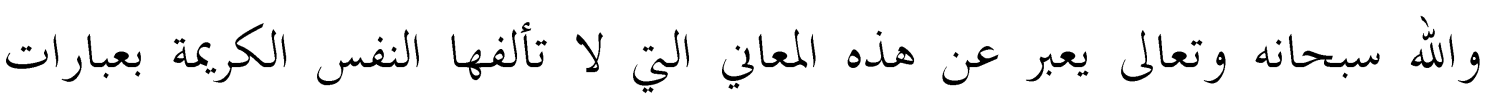

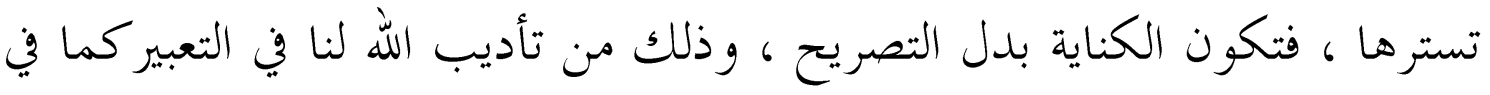

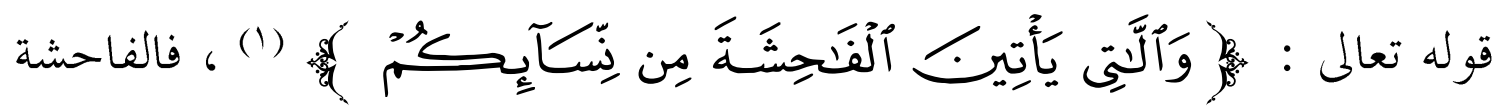

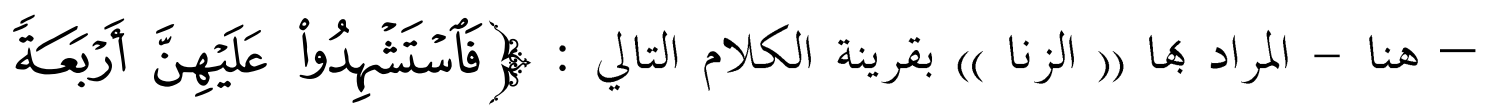
(1) كما وردت الكلمة نفسها لتدل على - عملية الشذوذ الجنسي- فعل قوم سيدنا

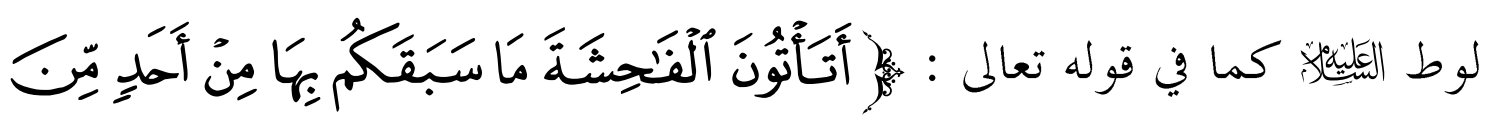

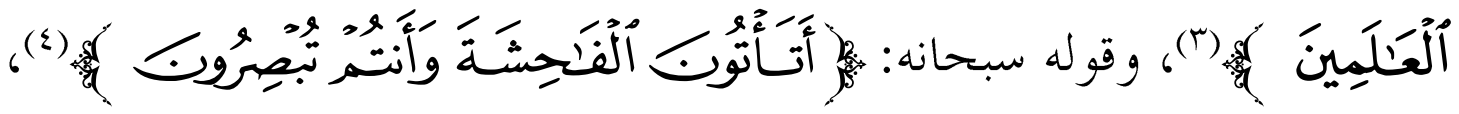

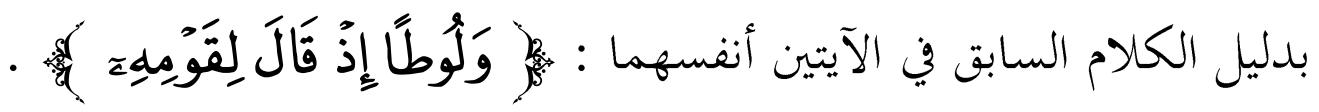

$$
\begin{aligned}
& \text { (1) من الآية } 0 \text { (1/النساء. } \\
& \text { (ז) من الآية نفسها. }
\end{aligned}
$$

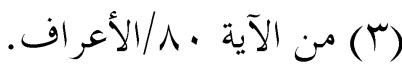

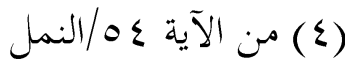


هذا وقد اعترض المشككون على هذه الكلمة وقالوا : إنّ هذا تناقض في معاني

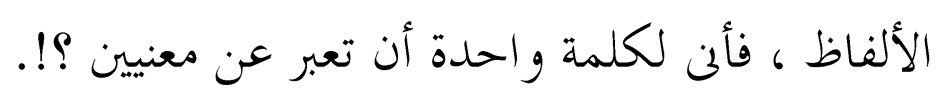

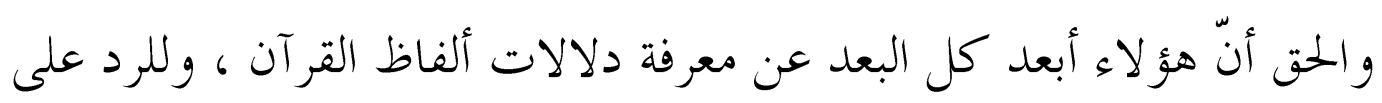
هذه الشبه كان لا بد من التأصيل الدلالي لهذه الكلمة.

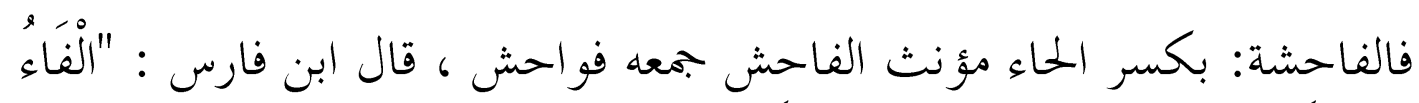

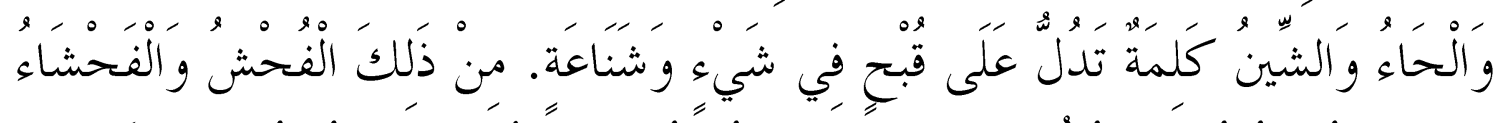

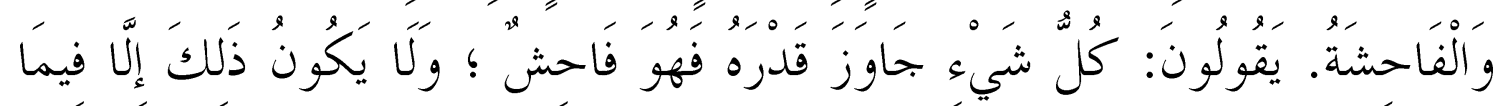

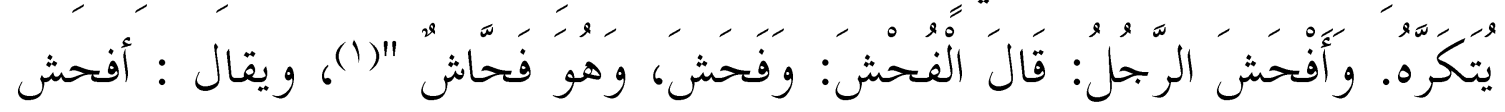
فلان في كلامه ..وتفاحش الأمر : تزايد في القبح (؟). و بالنظر إلى ما سبق ، فإنّ دلالة المعنى اللغوي الأصلي للفظ الفاحشة : تدل

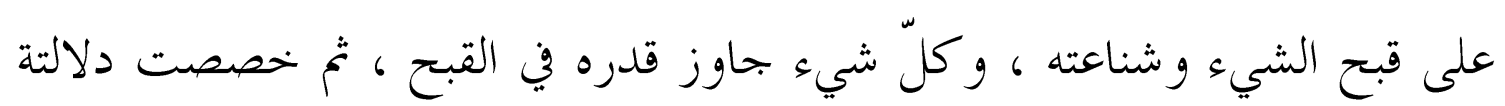

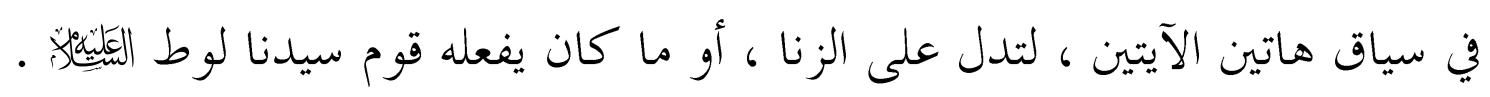
و بناءً على ذلك فإنّ كلمة (( الفاحشة )) تركز على ملح القبح الشديد في عملية الزنا و اللو اط وبحاوزة الحد فيهما. وبتتبع مادة ( ف ح ش ) في القرآن الكريم ، تبين أها وردت بثلاث صيغ

$$
\text { (فاحشة - فحشاء - فو احش ) (ن) }
$$

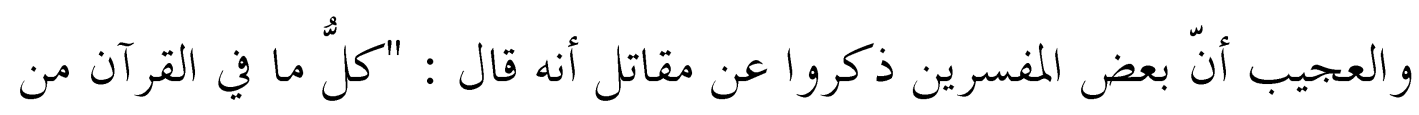

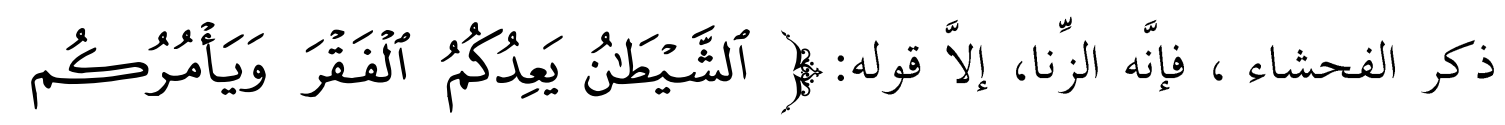

$$
\begin{aligned}
& \text {. ¿V^/乏) مقاييس اللغة (ف ح ش) (1) }
\end{aligned}
$$

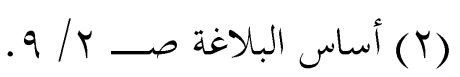




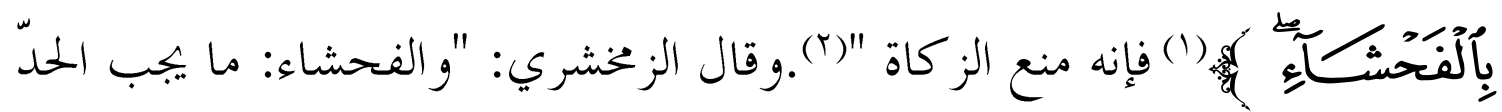

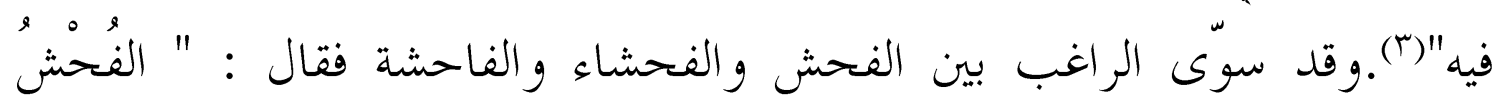

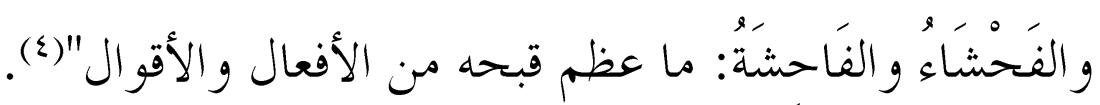

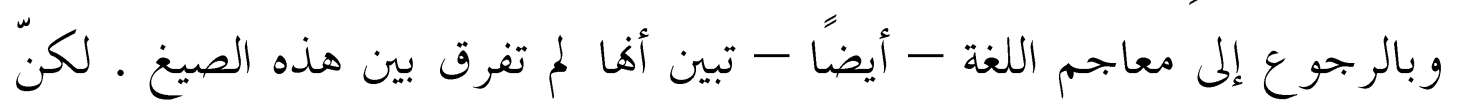

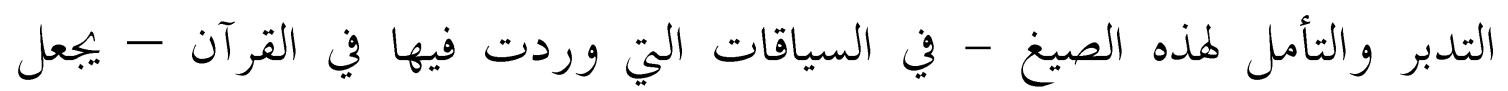
الباحث يقف على الفروق الدلالية بينها ، وبيان سرّ إعجازها.

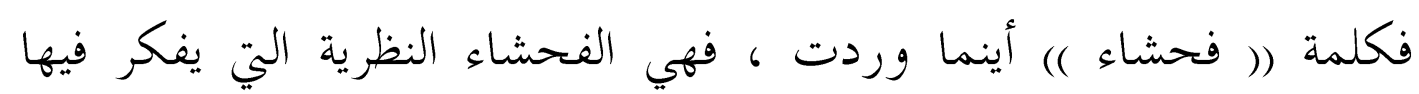

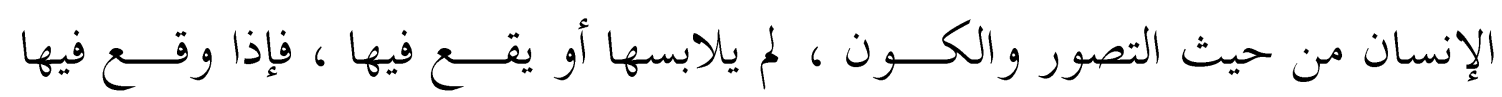

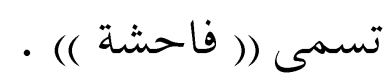

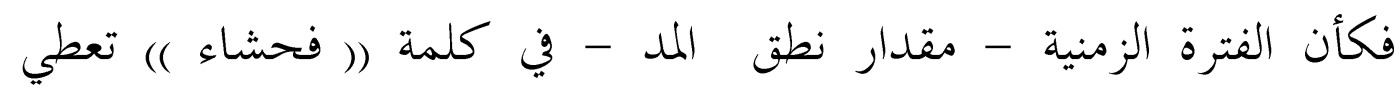
للإنسان فرصة للتفكير في عدم فعل الفاحشة والوقوع فيها ، كما في قوله تعالى :

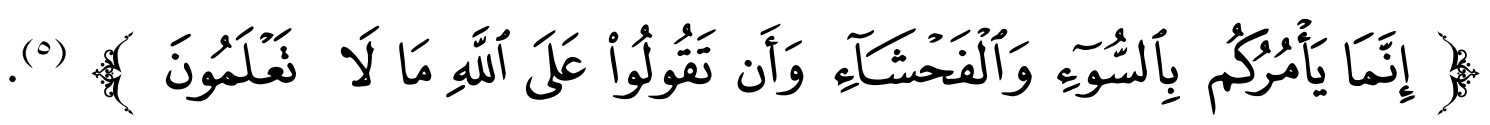

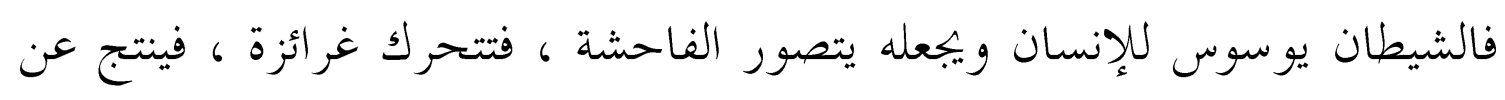

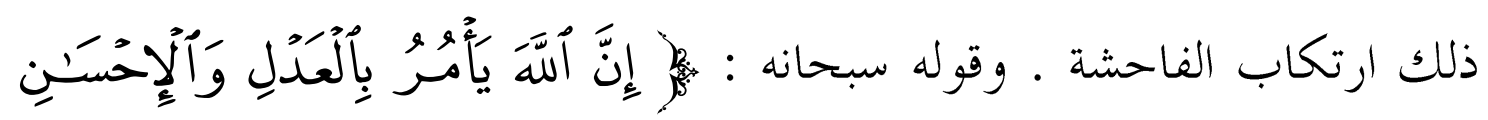

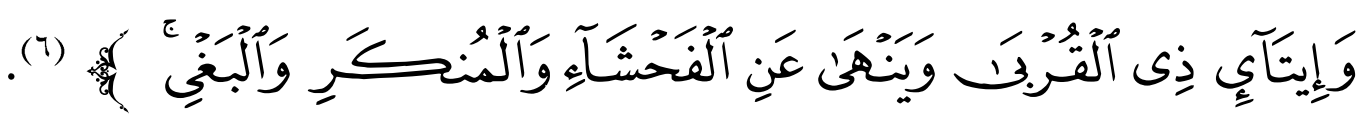

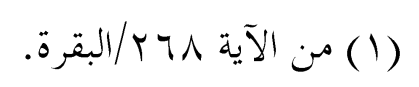

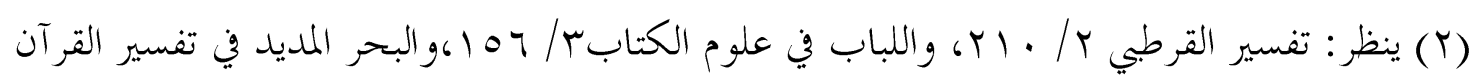

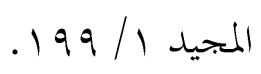

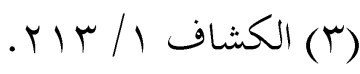

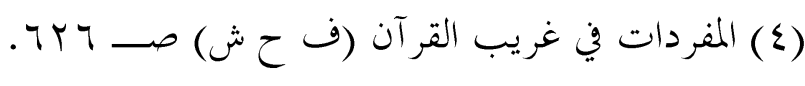

$$
\begin{aligned}
& \text { (0) الآية } 179 \text { /البقرة. }
\end{aligned}
$$

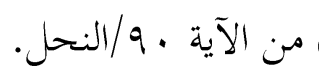


فالله سبحانه وتعالى ينهى عن التفكير والتدبير في أمر ارتكاب الفاحشة ،

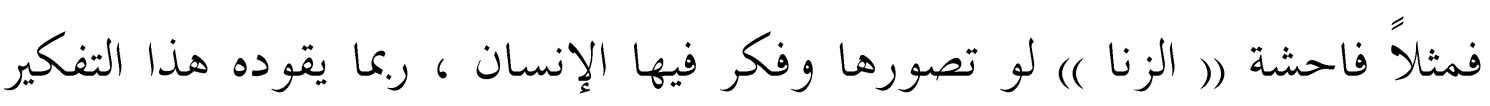

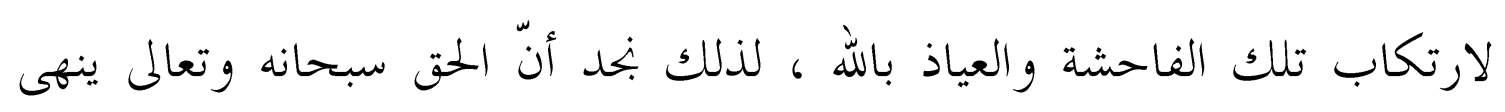

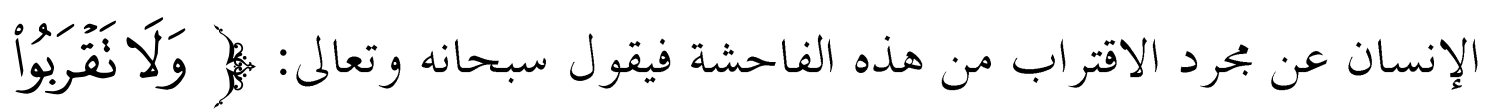

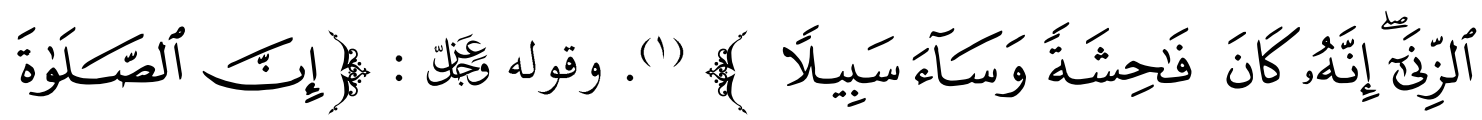

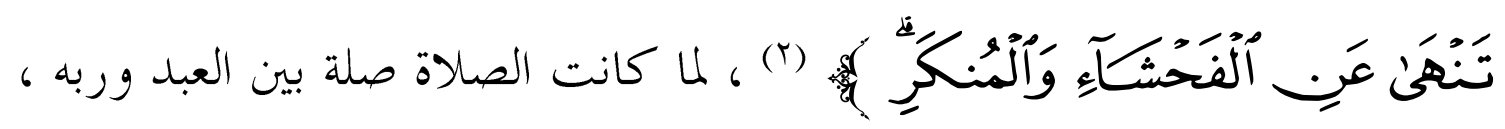
فهي بذلك تنهى عن (( الفحشاء )) أي : تنهى عن مجرد التصور و التفكر في

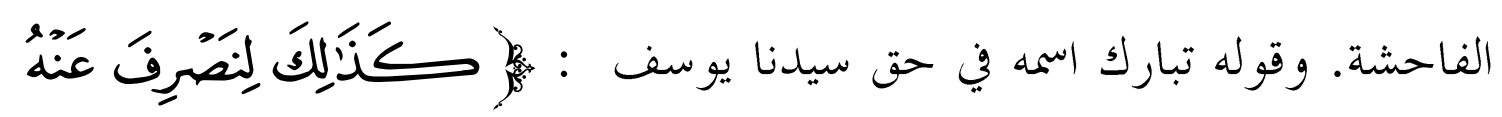

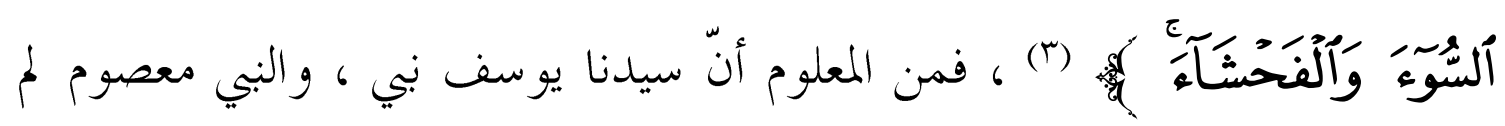
يذهب إلى السوء والفحشاء ، لكن السوء و الفحشاء قد جاءا إليه ، لذلك صرف

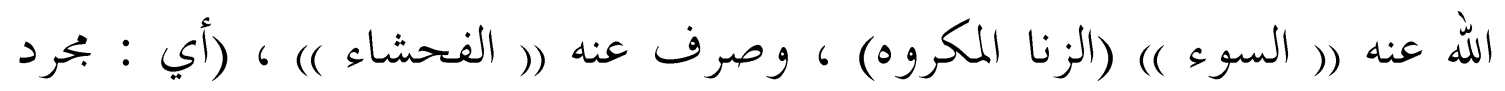
التصور و التفكر في الفاحشة )، فإذا كان الله قد صرف عنه تصور الفاحشة فمن باب أولى أن يصرف وف عنه الفاحشة نفسها.

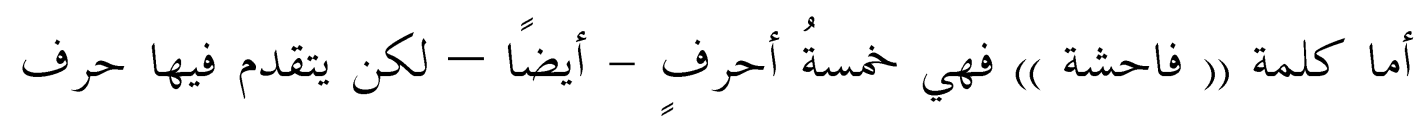

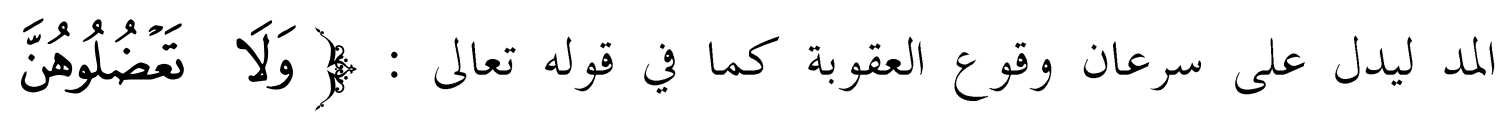

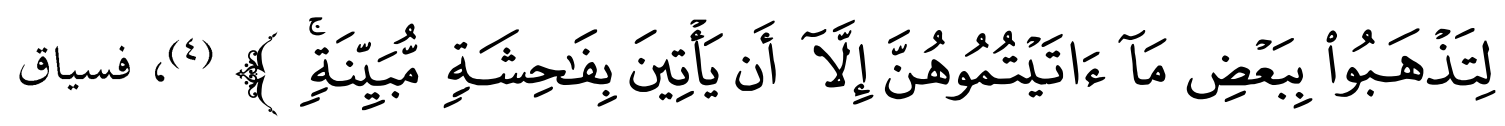

$$
\begin{aligned}
& \text { (1) الآية بr/الإسراء. }
\end{aligned}
$$

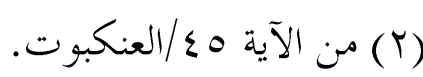

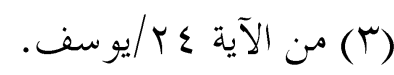

$$
\begin{aligned}
& \text { (ع) من الآية } 9 \text { ///النساء. }
\end{aligned}
$$


الآية يدل على أنّ العضول(1)، لا يكون إلا بعد الإتيان بالفاحشة وهي كما قال

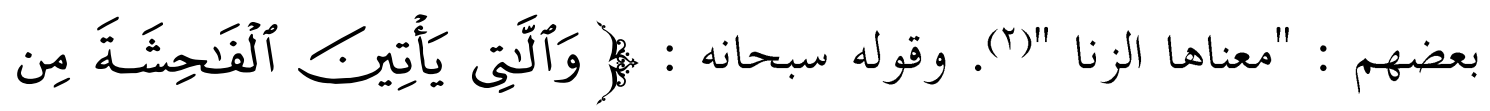

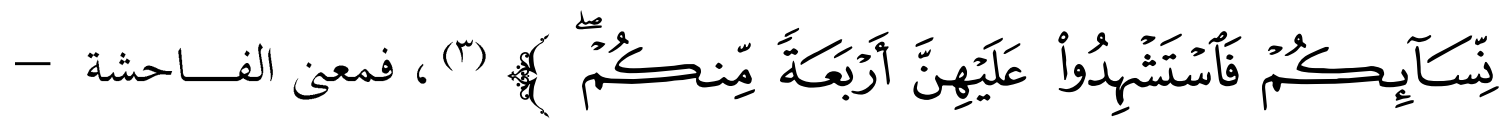

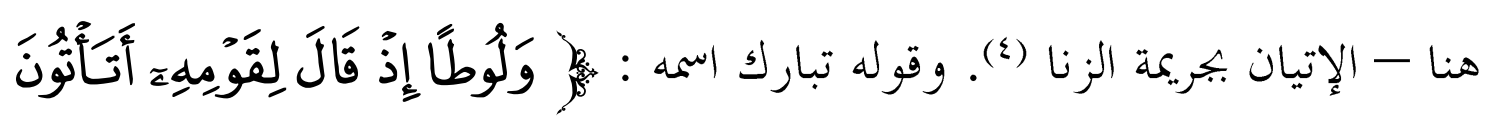

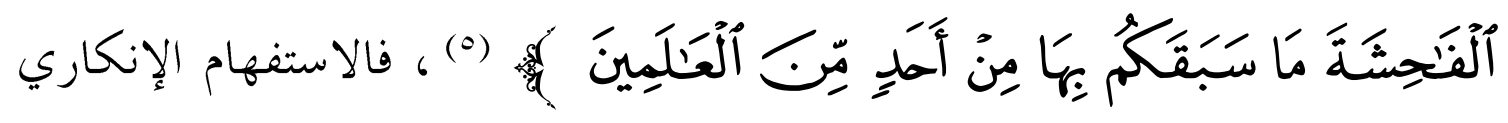

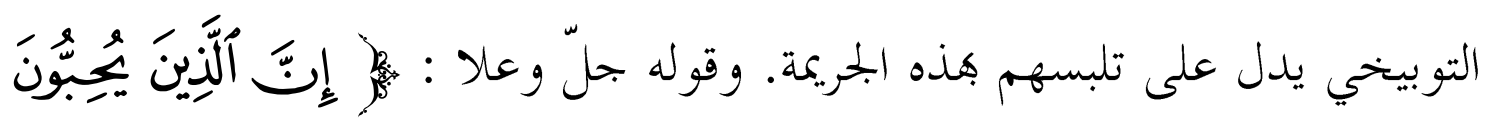

(1) أصل العضل : المنع ، يقال : 》عضلت المرأة بولدهاهي ، ذلك أصل الاشتقاق بالضبط. فالمرأة ساعة

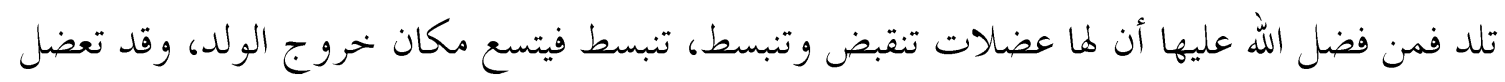

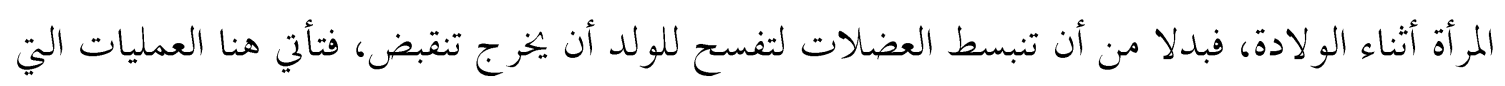

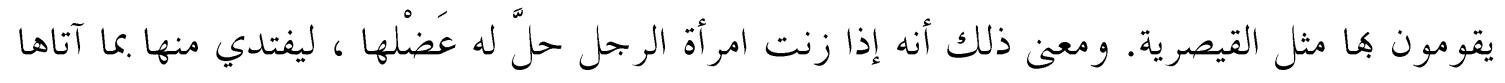

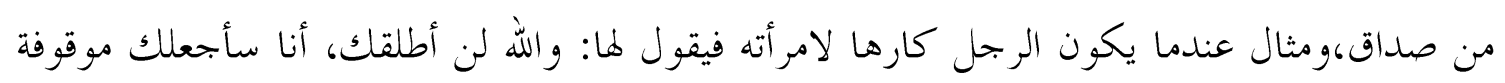

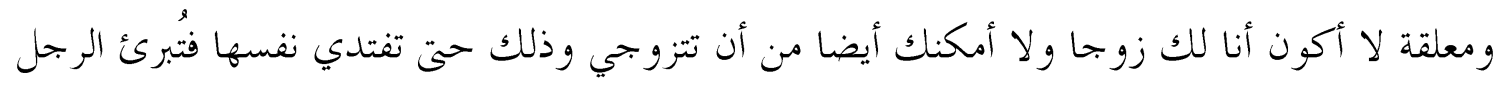

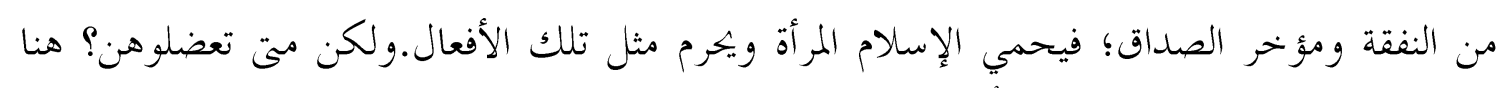

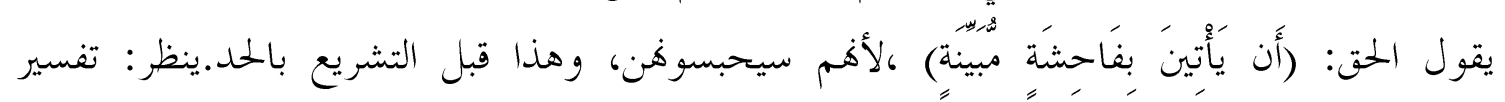

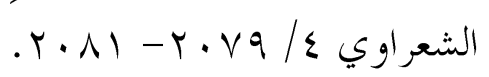

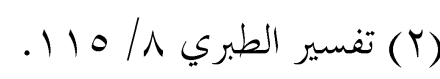

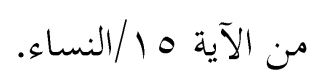

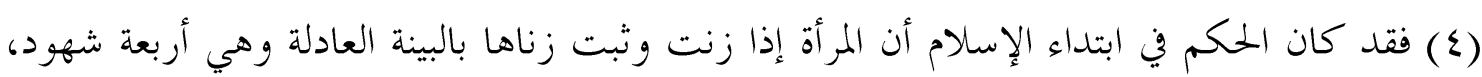

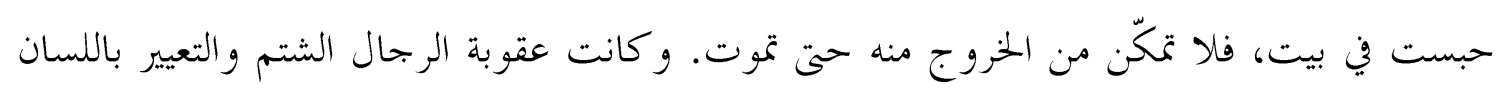

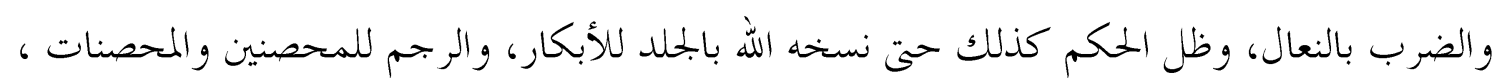

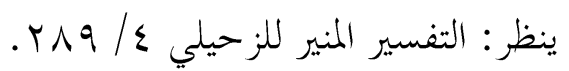

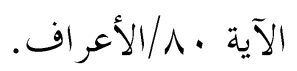




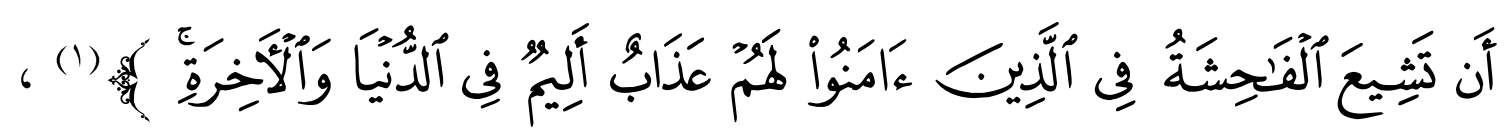
ففي شيوع الفاحشة دلالة على حديث هؤلاء المنافقين بالإفك و الفرية والافتراء في حق السيدة عائشة رضي الله عنها.

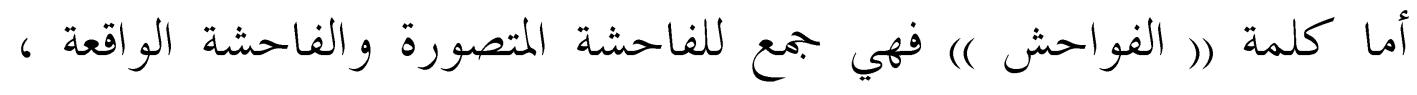

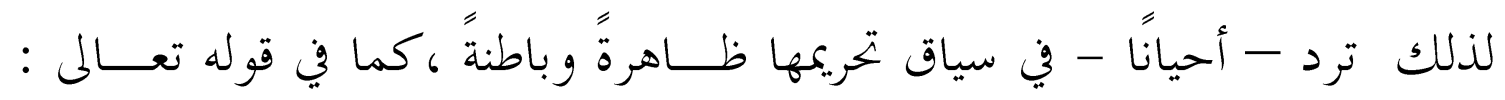

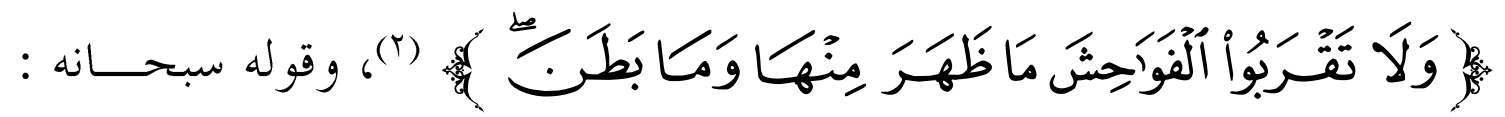

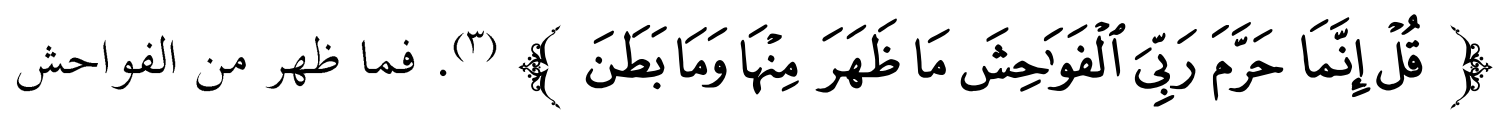

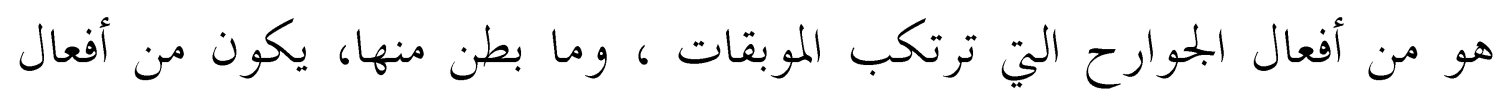

$$
\begin{aligned}
& \text { السر ائر مثل الحقد ، و الغل ، و الحسد (؛) . } \\
& \text { يستنتج مما ما سبق : }
\end{aligned}
$$

أنّ هناك فرقًا بين الفحشاء و الفاحشة ، وأنّ تر كيب (( فحش ) ) في أصل معناه

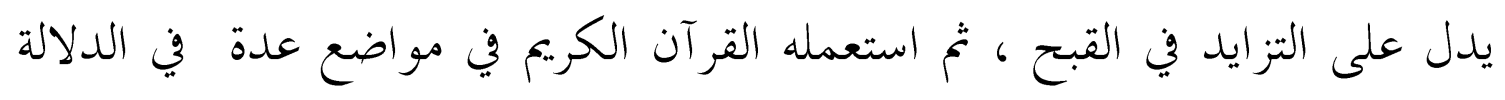
على :

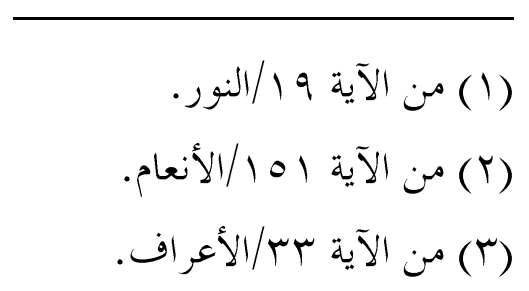

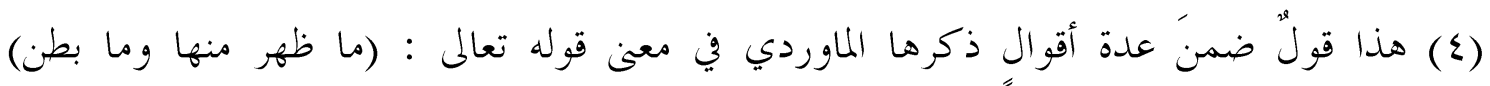

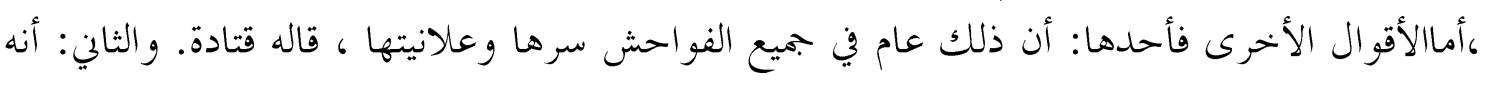

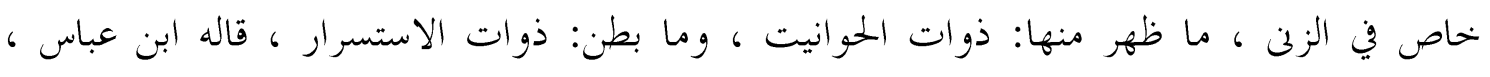

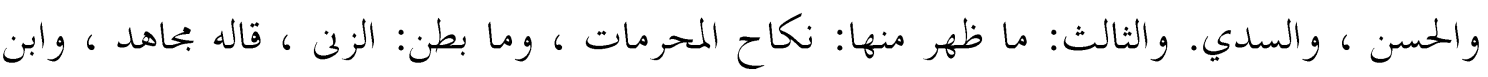

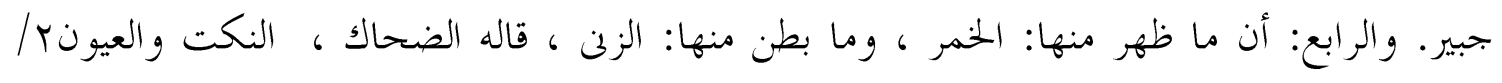




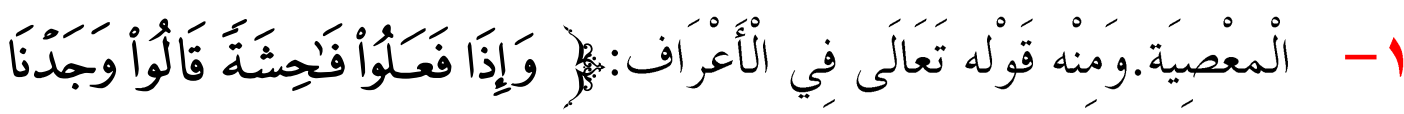

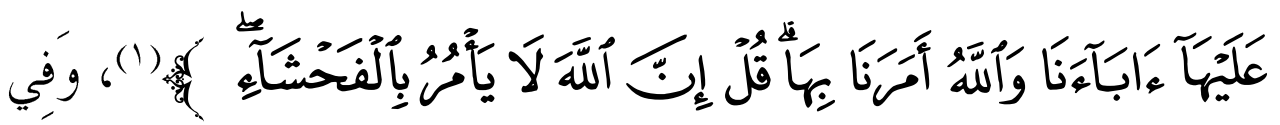

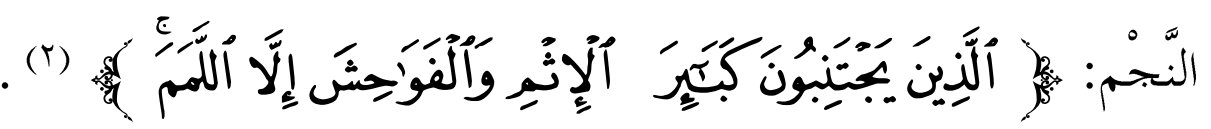

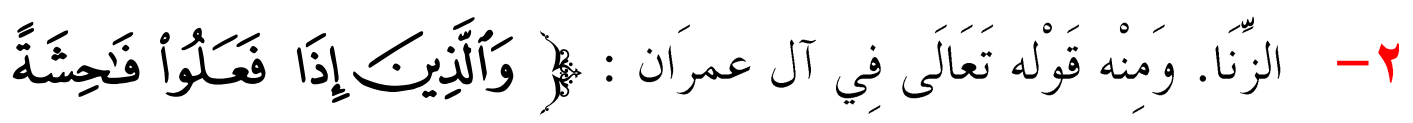

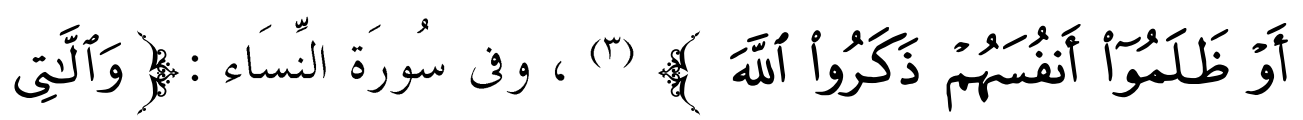

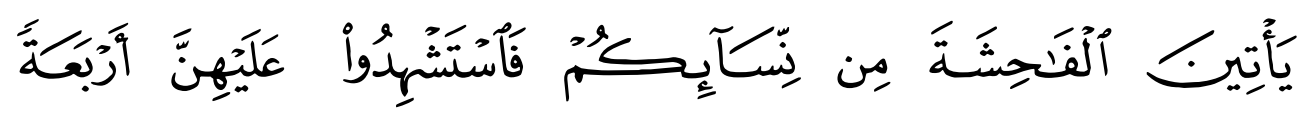

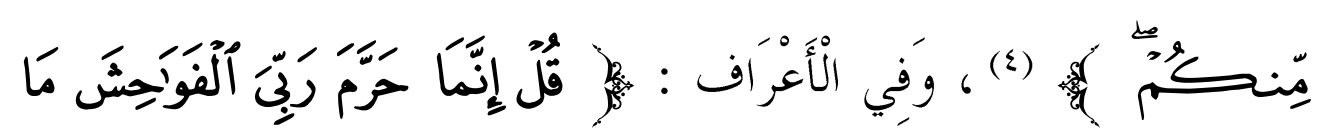

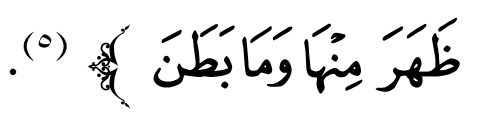

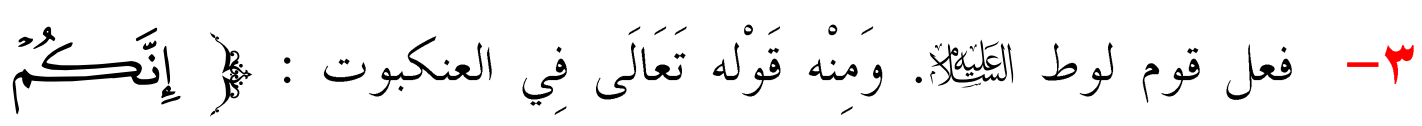

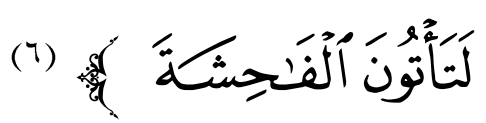

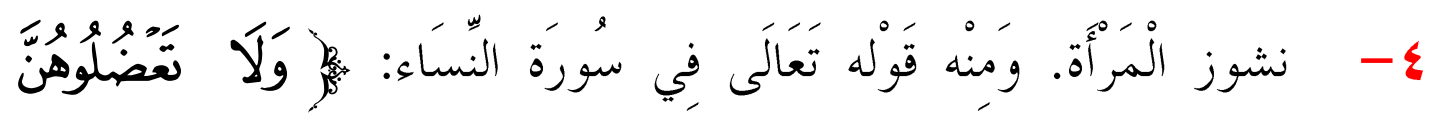

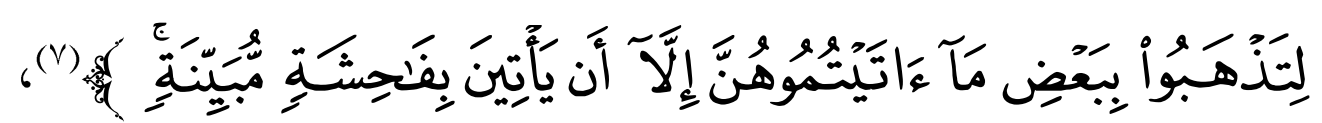

$$
\begin{aligned}
& \text { (1) من الآية م/ /الأعراف. }
\end{aligned}
$$

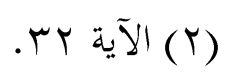

$$
\begin{aligned}
& \text { (Y) من الآية هبr) } \\
& \text { ( ) من الآية } 10 . \\
& \text { (0) من الآية سب. } \\
& \text { (7) من الآية مᄉ الاية } \\
& \text { 1 } 19 \text { من الآية }
\end{aligned}
$$




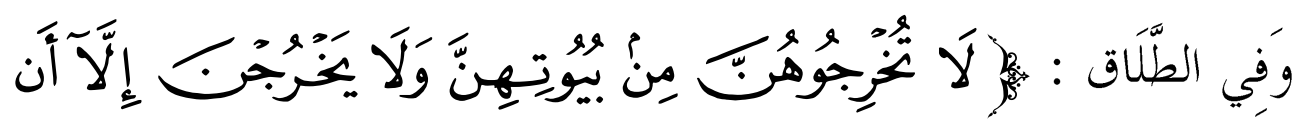

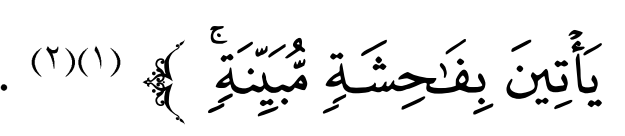

إذن فالسياق - وغيره من قرائن فهم المعنى - هو الذي يجدد معنى اللفظ ،

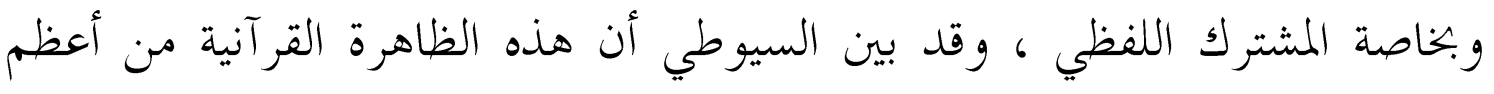

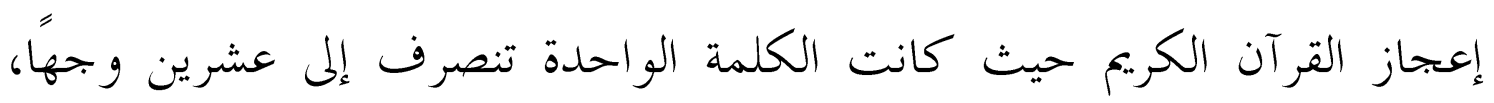

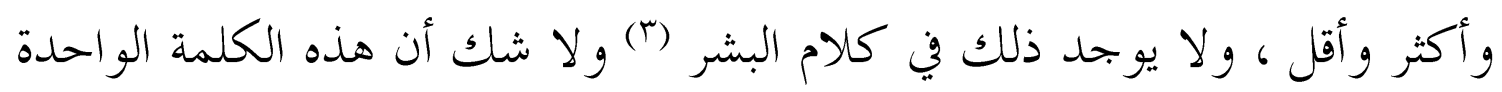

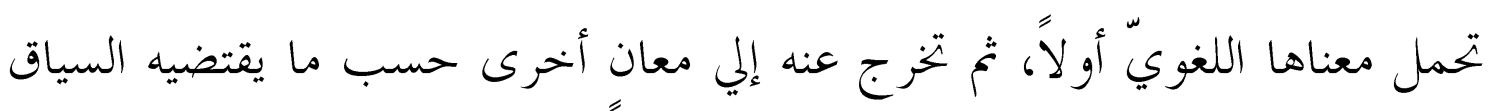

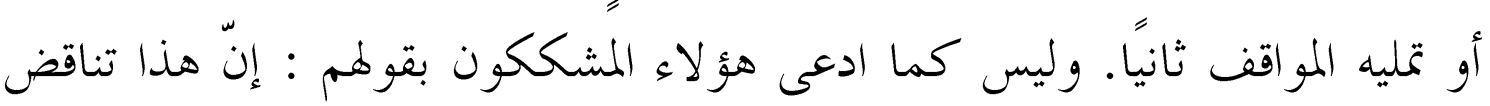
في معاني الألفاظ فأنى لكلمة واحدة أن تعبر عن معنيين ؟! ولئ.

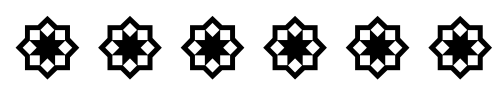

$$
\begin{aligned}
& \text { (1) - (1) من الآية //الطلاق. }
\end{aligned}
$$

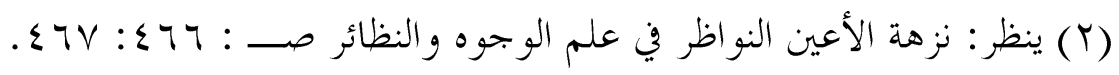

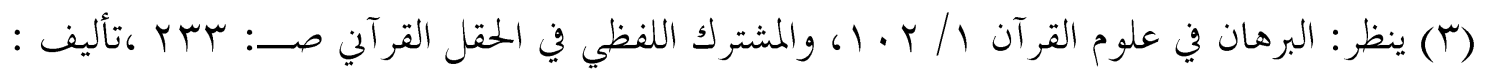

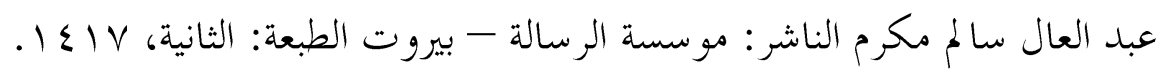




\section{المبـهث الثانيه : دلالة لفظة ( أخدان ) :}

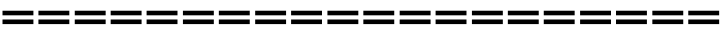

وردت لفظة (( أخدان )) مرتين في القرآن الكريم للدلالة على العلاقة الجنسية

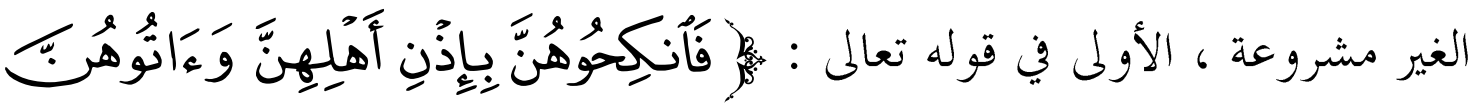

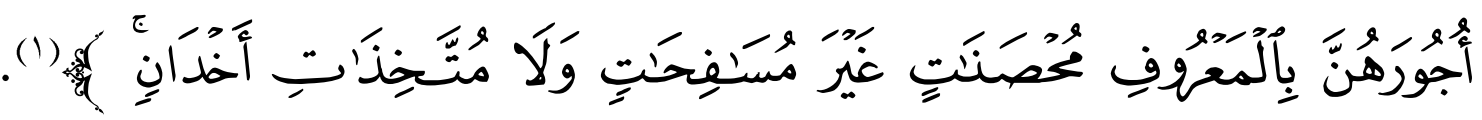

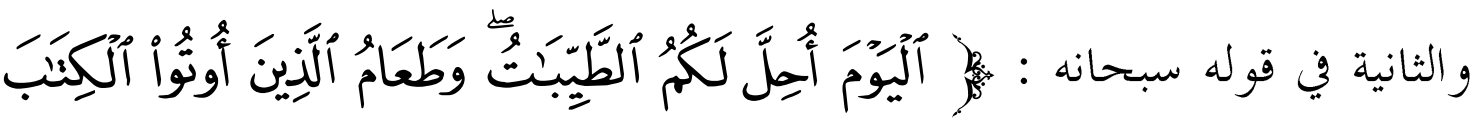

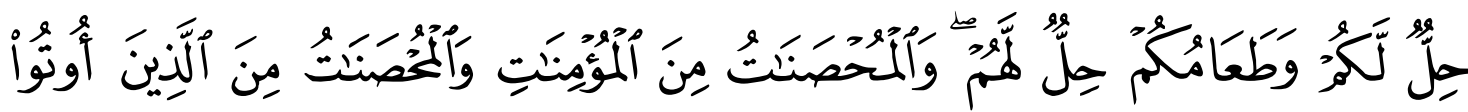

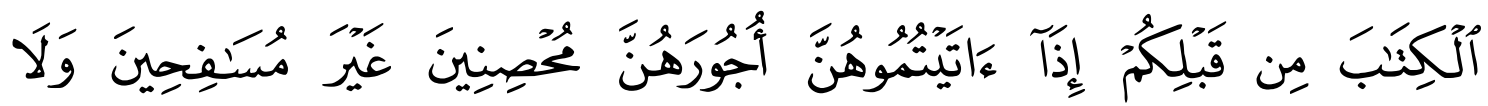
(1)

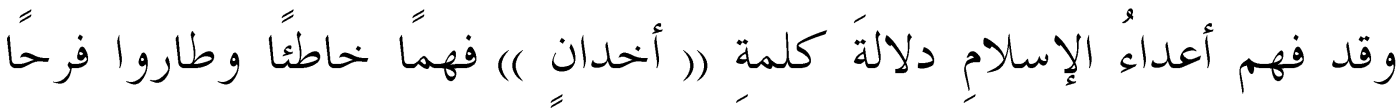
يتهمون الإسلام بالانغلاق الفكري والتأخر الاجتماعي في العادات والعلاقات ،

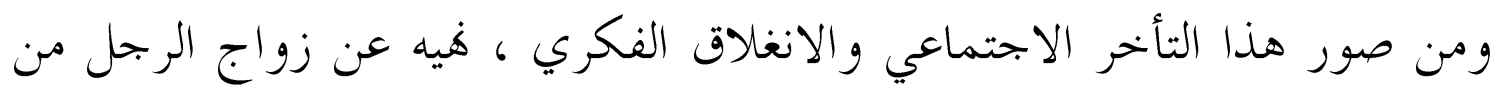

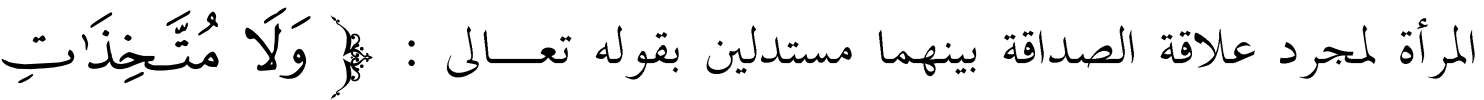

$$
\text { (1) من الآية هب/النساء }
$$




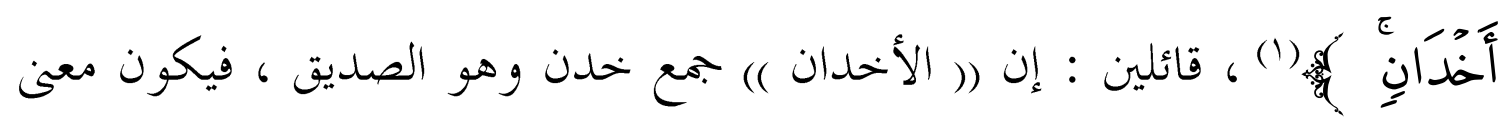

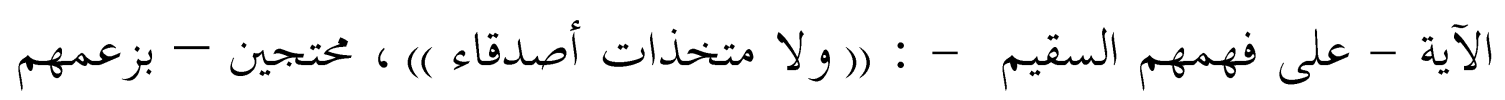

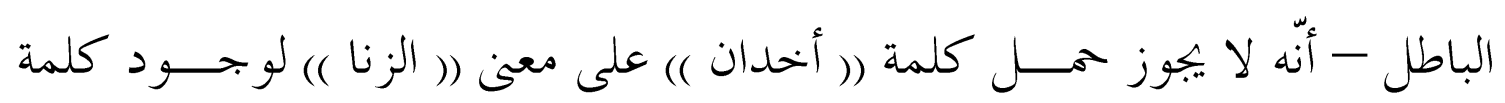

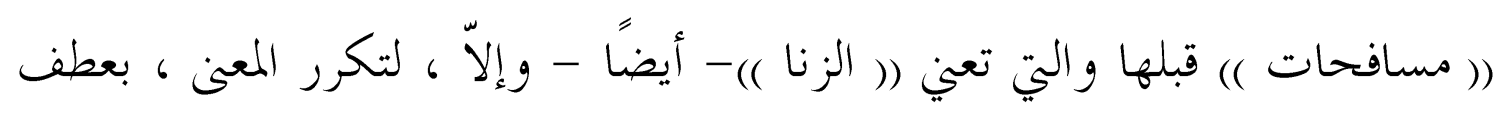
الشيء على نفسه. والحق أنّ هؤلاء لم يفهموا الدلالة المرادة من اللفظة القرآنية داخل سياقها ،

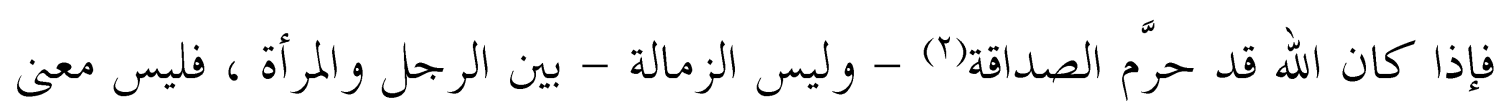

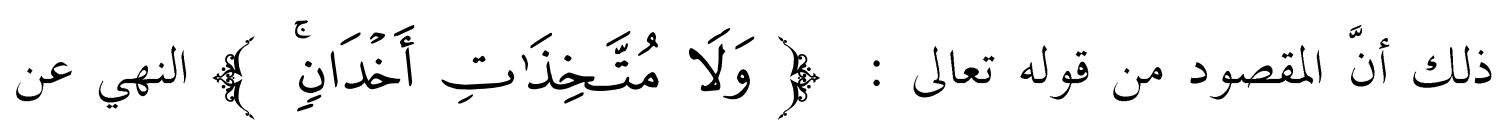

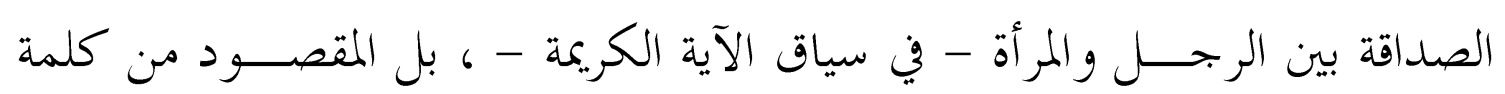

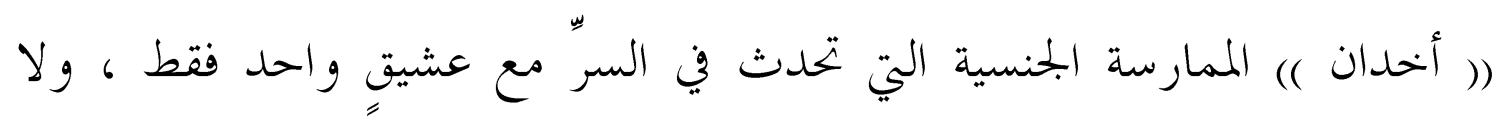
يتعارض ذلك مع تقدم كلمة (( مسافحات )) والتي تعني : الممارسة الجنسية مع أكثر من شخص ، فلكل تعبير دلالته وإعجازه.

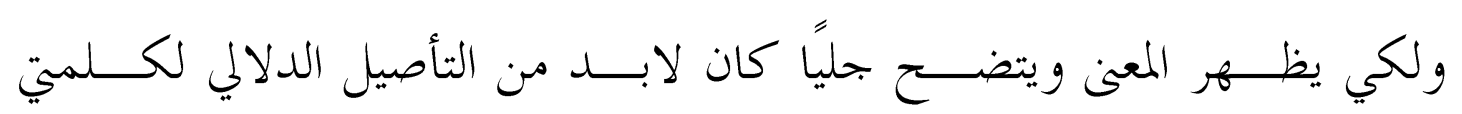
(( مسفحات ، وأخدانٍ ) ) وربط دلالتهما بسياق ورودهما.

$$
\text { أولا: لفظة : ( أخدان ) : أران }
$$

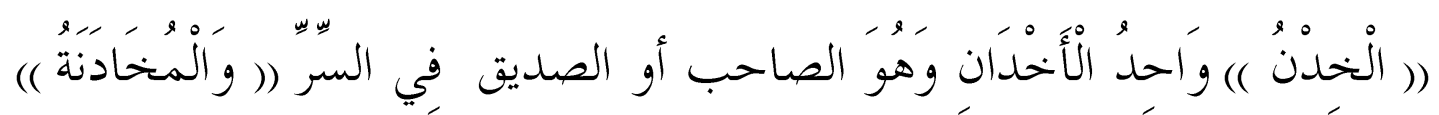

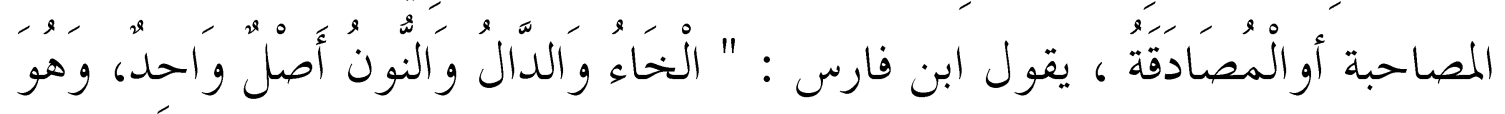

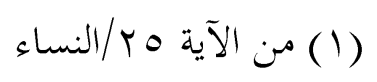

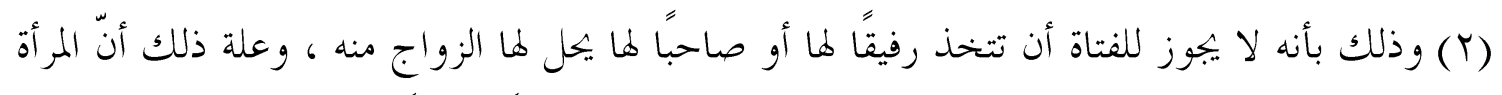

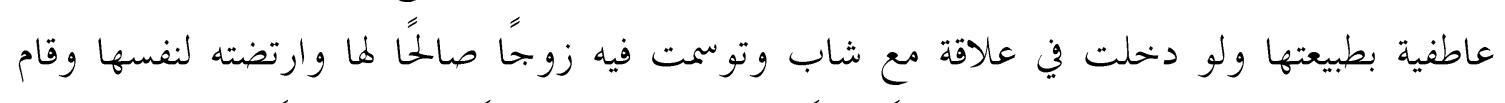

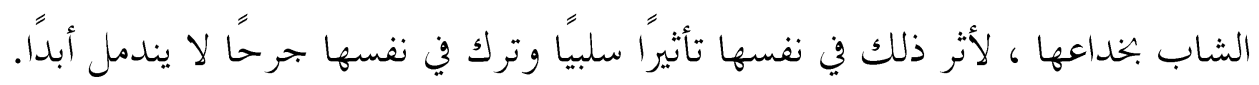




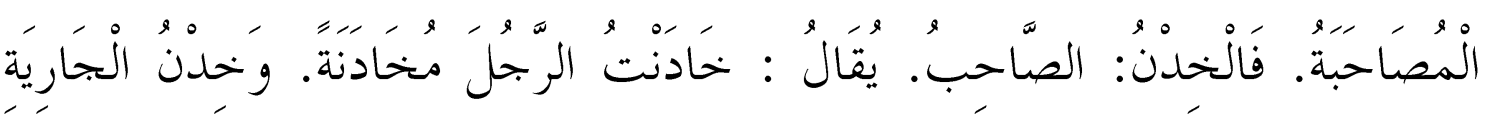

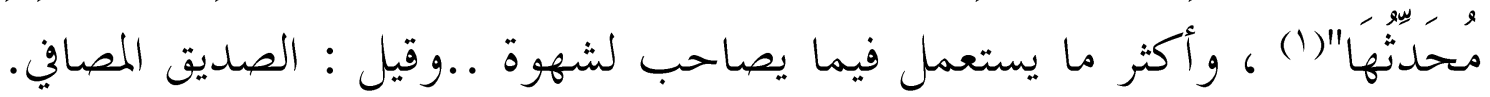

$$
\text { وقيل الصديق في السر(r). }
$$

ثم انتقل اللفظ انتقالاً دلاليًا من دلالته على الصداقة والمصاحبة وأصبح يدل على صحبة الزانيات للزناة و الزنا معهم سرًا. وبذلك يتميز لفظ (( الخدن )) عن لفظ (( الصاحب أو صديق )) .بمامح دلالية هي - 1 - المصاحبة بشهوة. Y - المصاحبة الصافية ، و تتمثل في صفاء المرأة تجاه من يصاحبها وعلة ذلك،

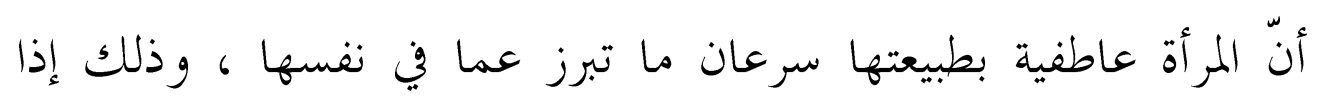

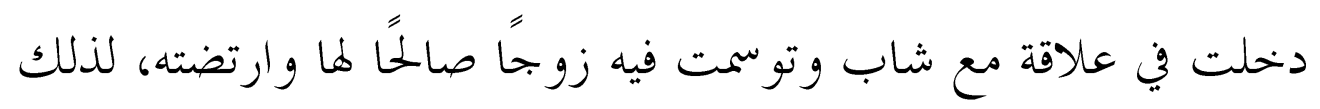
حرم الإسلام كل علاقة بين الجنسين خارج نطاق الزواج · وليس في الإسالام ما يعرف بالحب بين الجنسين خارج نطاق الشرع ، وكم أحدثت تلك الصدقات من مفاسد عظيمة ! فضلاً عن ارتكاب معصية

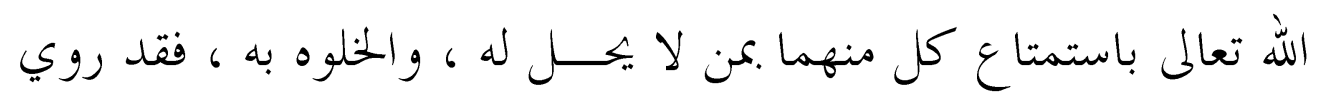
عن البني

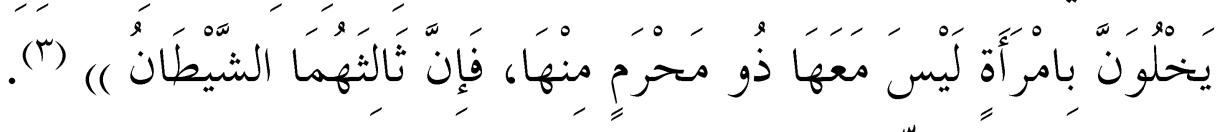

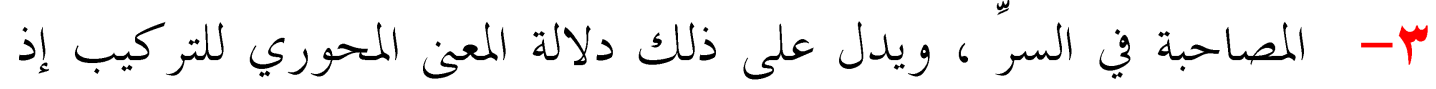
يدل " على المداخلة و المباطنة ـ ففي المخادنة من السرية و التخفي ما ليس

$$
\begin{aligned}
& \text { (1) مقاييس اللغة (خ د ن) r/ rד } 1 .
\end{aligned}
$$

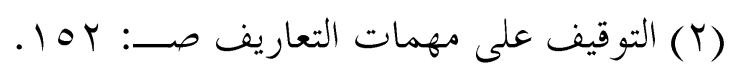

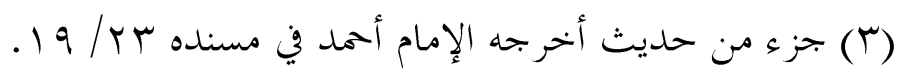


في المصادقة .. فكأنَّ الخِذْن يدْخل في باطن من يخادنه ـ فهذا يعطي شدة

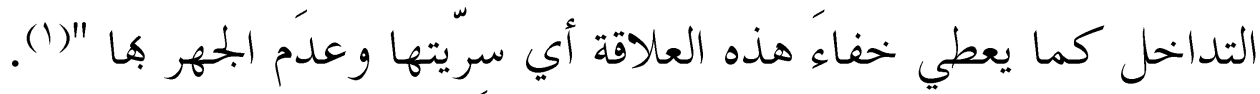

\section{ثانياً: لفظة : ( مسافحات ) :}

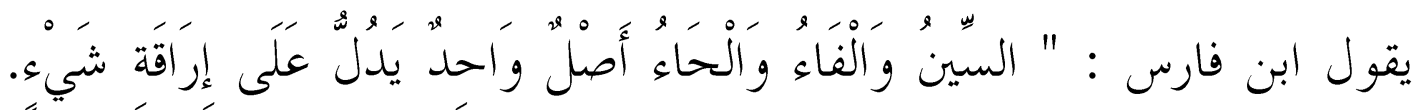

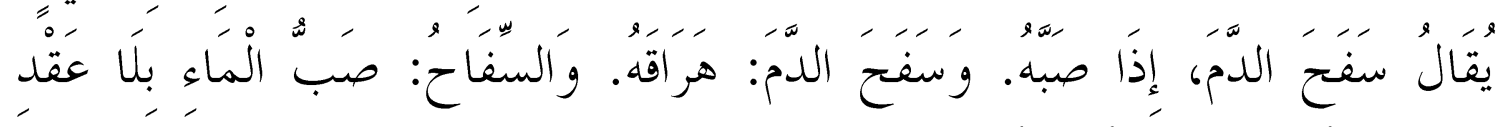

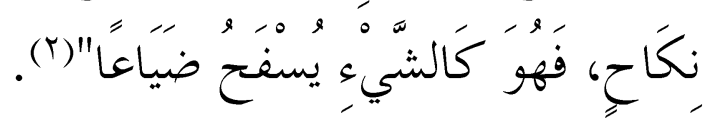

ثم انتقل اللفظ من معناه الأصلي (الدلالة على الإراقة) وأصبح يدل على على

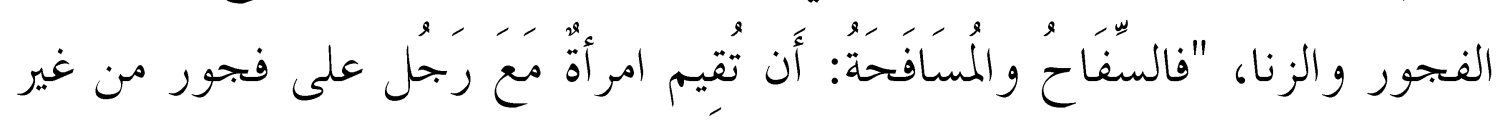

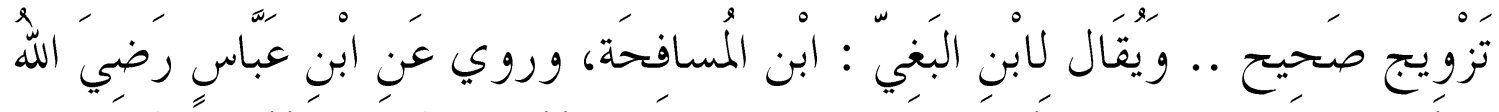

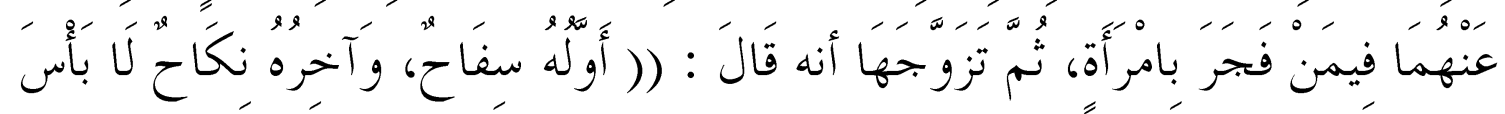

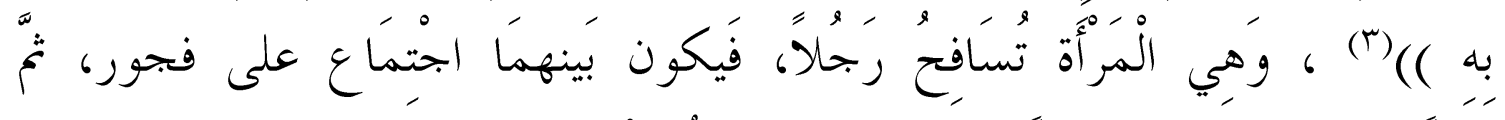

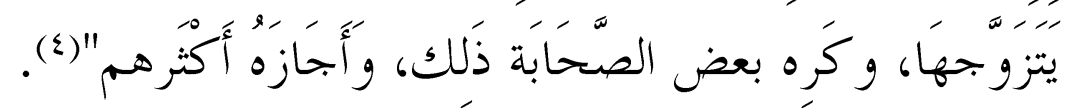
وسمي الزِِّن سفَاحًا:

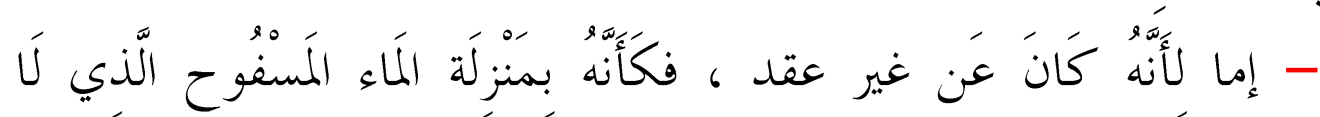

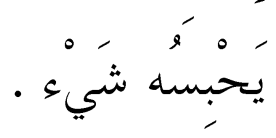

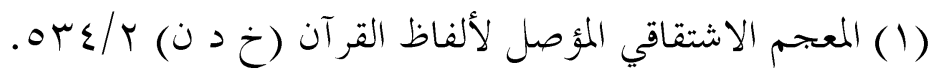

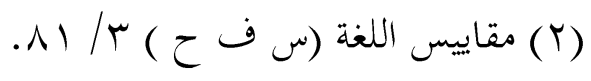

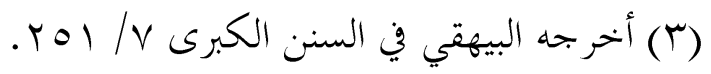

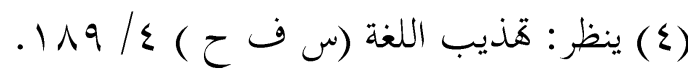




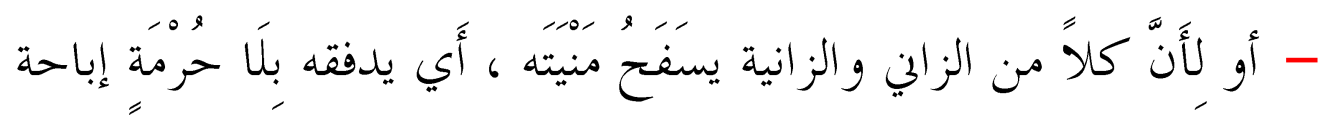

دفقها) (1)

ومن ثُّ يسمى الزاني مسافحًا، لأنه ليس يتعلق به حكم ثابت مستمر، وهو

نسب أو عدة أو مهر.

إذن هناك فرق بين المرأة المسافحة والمرأة المخحادنة .

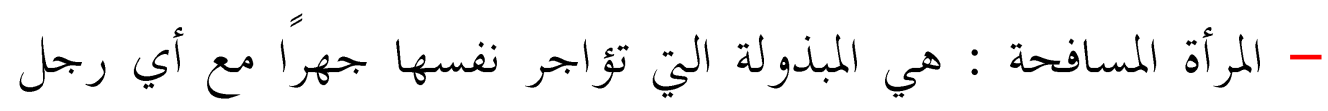
أرادها من غير عقد يربط هذه العلاقة . لمان.

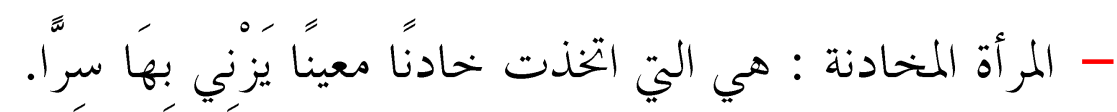

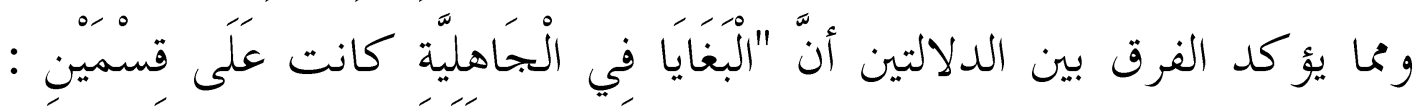

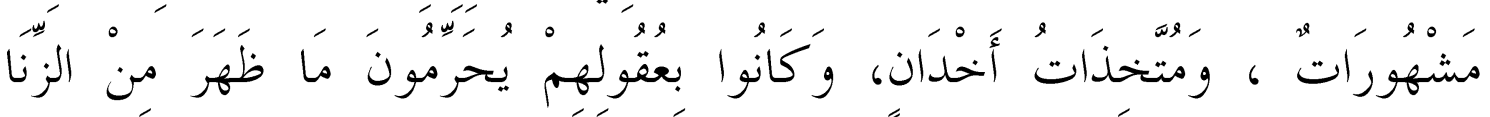

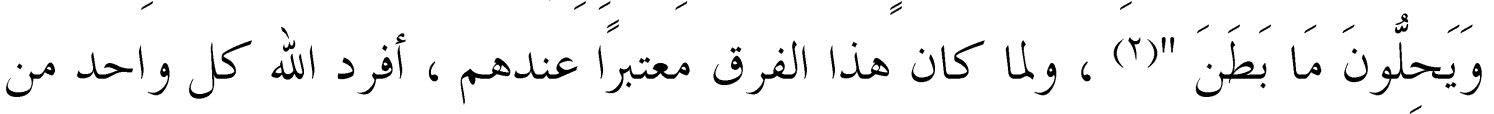

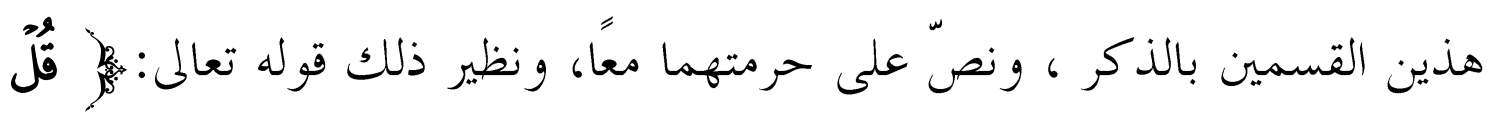

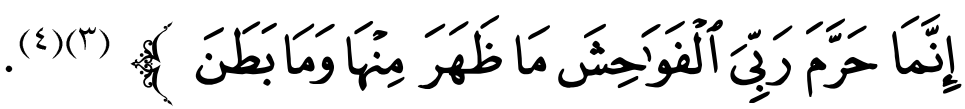

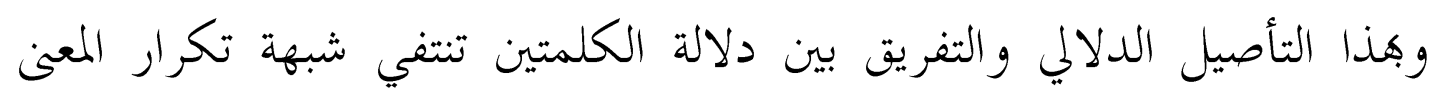

بعطفه على نفسه وإثبات الفرق الدلالي بين اللفظتين . 
و.بمعرفة دلالة كلمة (( أخدان) )) والرجوع إلى السياق الذي وردت فيه ، يتبين

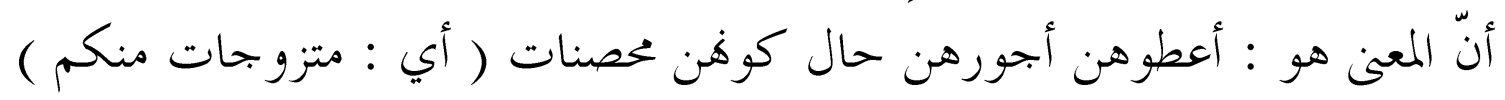

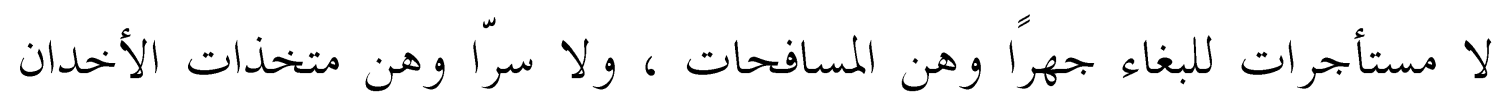

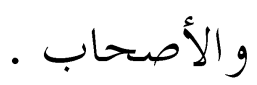

إذن فليس معنى قوله تعالى: (( ولا متخذات أخدان )) النهي عن الصداقة كما فهمه أعداءُ الإسلامِ وراحوا يتهمونه بالانغلاق الفكري و التأخر الاجتماعي . ولو كلَف هؤلاء أنفسهم بقراءة الآية من أولها ، لعلموا علم اليقين أنّ الإسلام أراد أن يرتقي بالمر أة حفاظًا على شرفها وتلكريمًا لشأهنا .

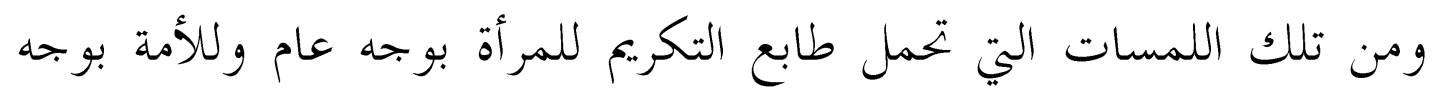
خاص ، ما دلّ عليه سياق الآية الكريمة من دلالات أذكر منها : 1- الإباحة لمن قصرت يده عن التزوج من الحرائر، وخشى على نفسه الوقوع فن المعصية، وغشيان المنكر - أن يتزوج من الإماء، حيث مهرهن

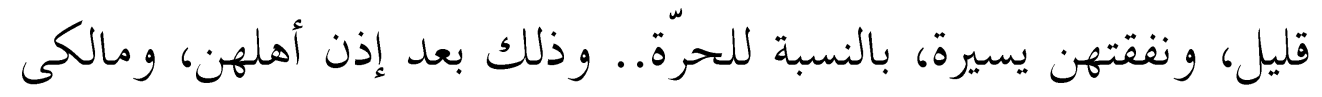

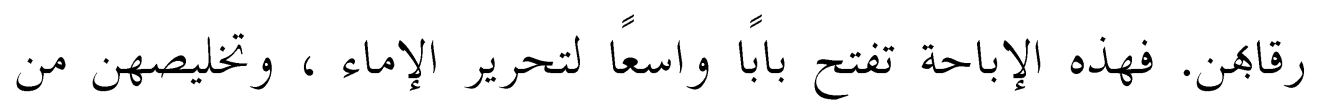
الرق.. فو اجب الرجل الذي تزوج بالأمة ، أن يهصنها وأن يبعدها عن التبذل والامتهان ، اللذين يغلبان على حياة الإماء.. فالزوجة الأمة، ليست هى الآن أمة في الحياة الزوجية ، وإنما هى زوجة ، لها عند الرجل

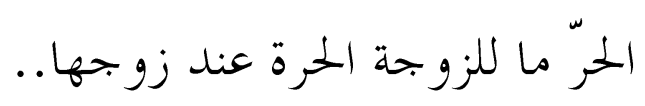

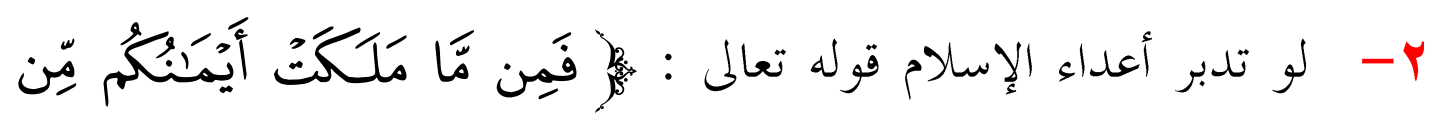

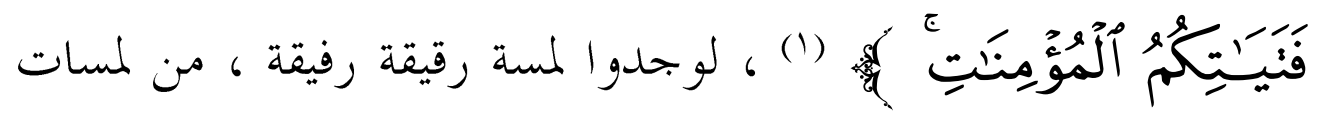


الدلالة اللغوية بين رقي القرآن وشبهات المستشرقين وجهلهم بإعجاز اللفظ القرآني.

السماء ، لتعطف القلوب على هؤلاء الفتيات ، ولتفتح عليهن باب

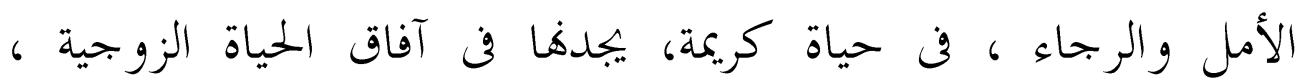
ويخر جن هـا عن دائرة العبودية ، و الامتهان!.

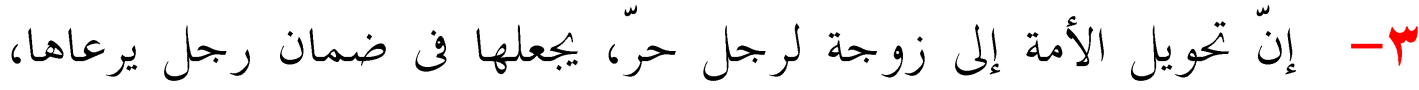

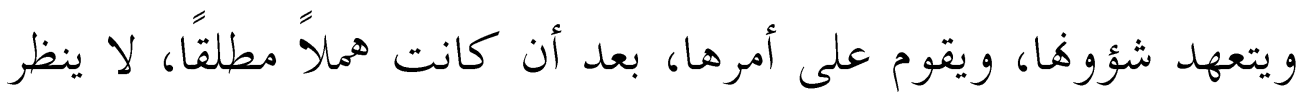

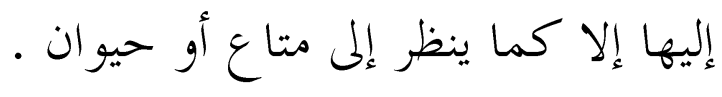

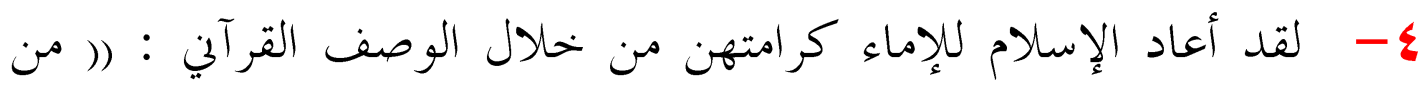

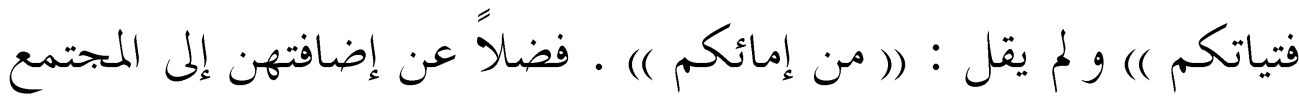

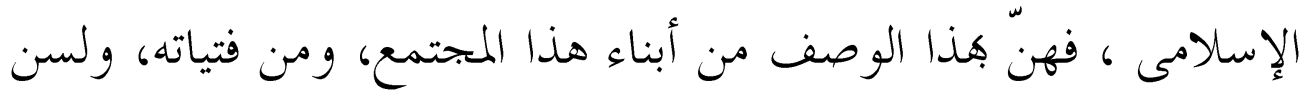

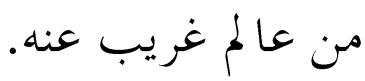

0- وصفهن بالمؤمنات ، فئم مقابل وصف الحسرائر المحصنات هذا

الوصـف

..

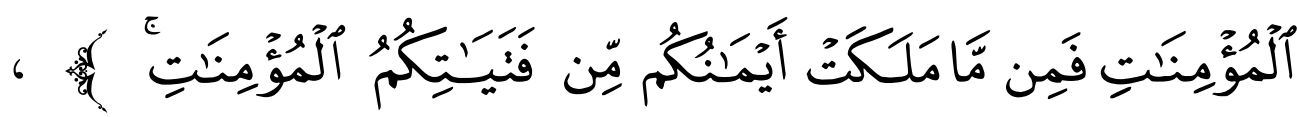

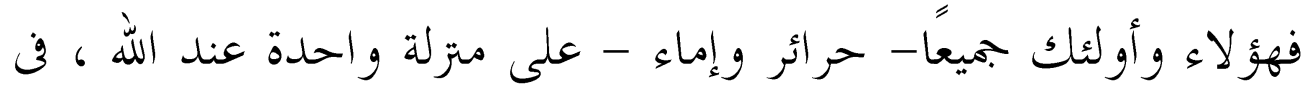
التعرف إليه ، والإيمان به... وفى هذا المقام يكون التفاضل بين إنسان

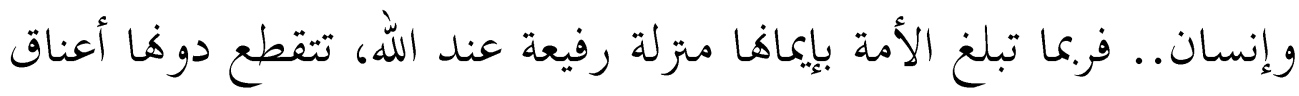

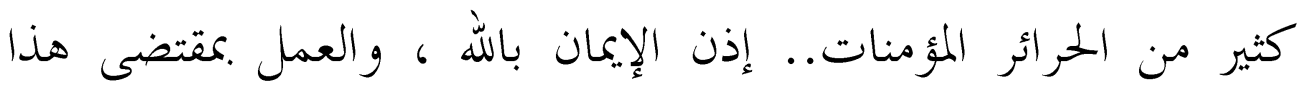

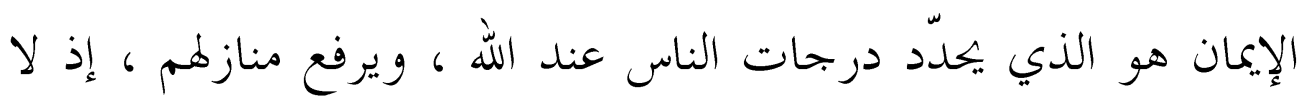

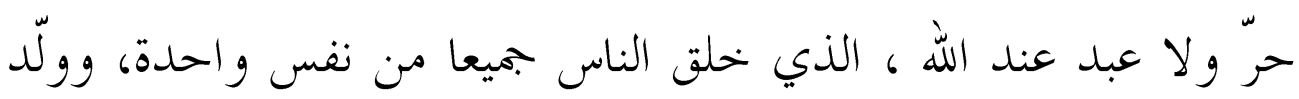

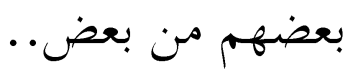


7- مساواة الأمة بالحرّة في أها تستحق المهر عند الزواج وهو قوله تعــالى :

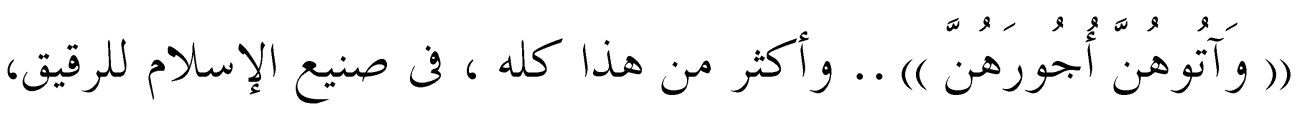
و وفى العمل على فلك رقبته.

-V إنما هو حق هلا. لذلك يخرج من قاعدة أن كسبها كله له ـ فهذا ليس

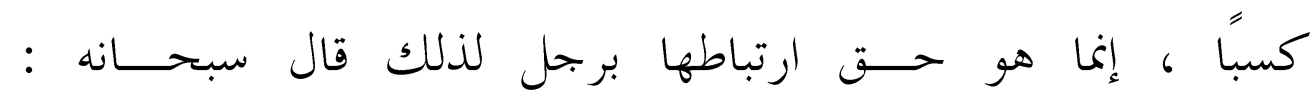

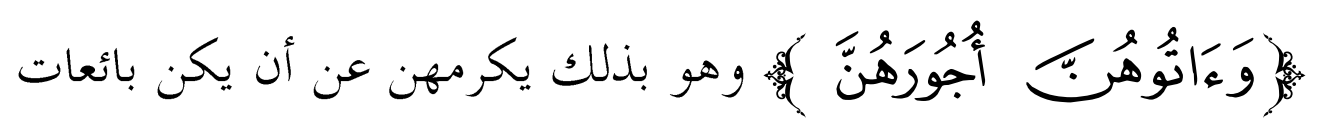

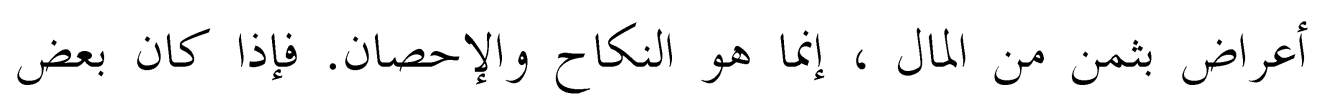

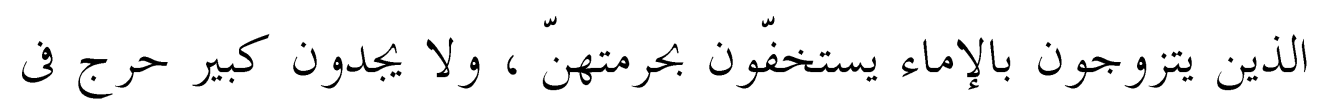
أن يظللن على حياقن قبل الزواج من التبذل والامتهان- فإن فيما لفتهم

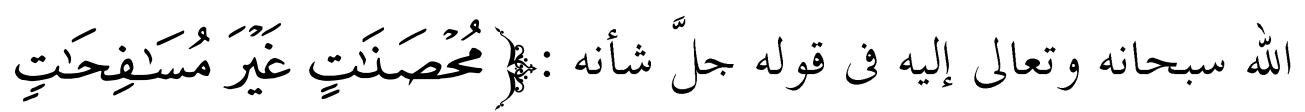

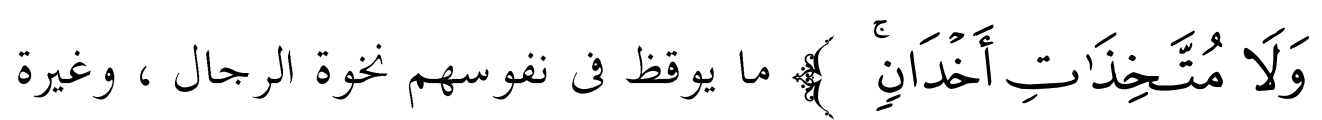
الأحرار، وبسط أيديهم على أولئك الزوجات ، الأمر الذي لا يستقيم إلا إذا تحررت الزوجات من الرّق وخلصت وبست لأيديهم (1).

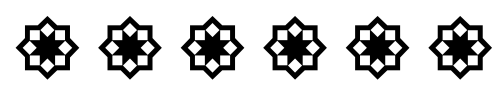


المبحثَ الثالث : في دلالة تركيب: ( ظاهر الإثم وباطنه ) :

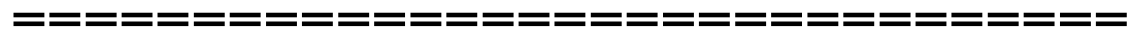

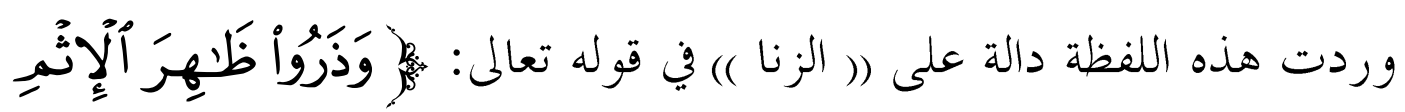

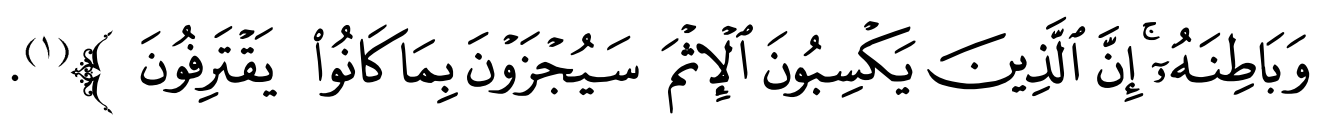

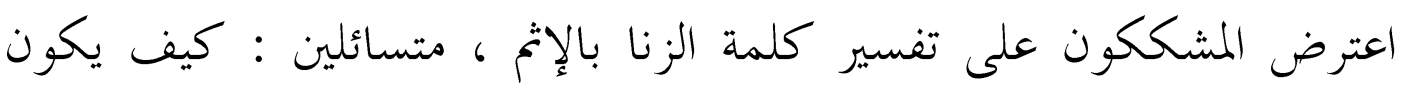

للزنا ظاهر وباطن ؟.

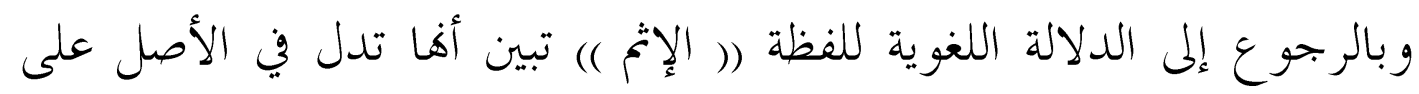

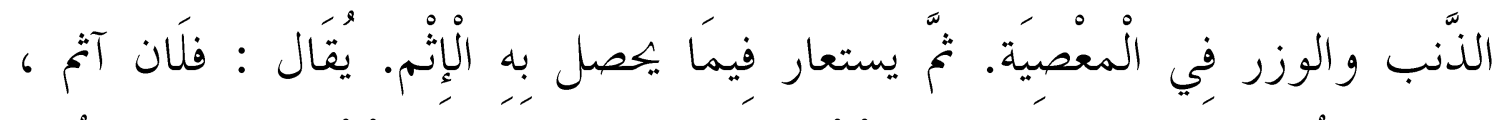

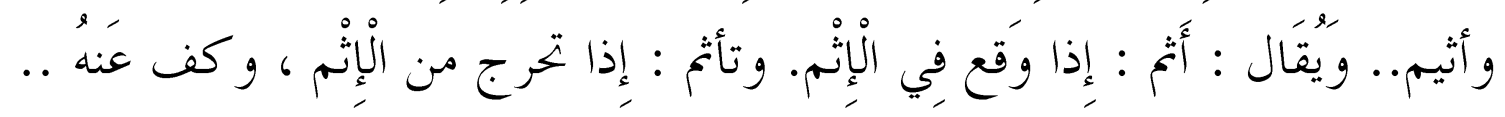

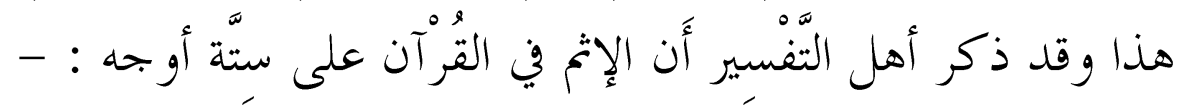

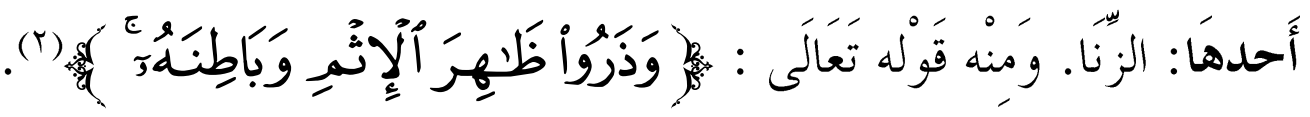




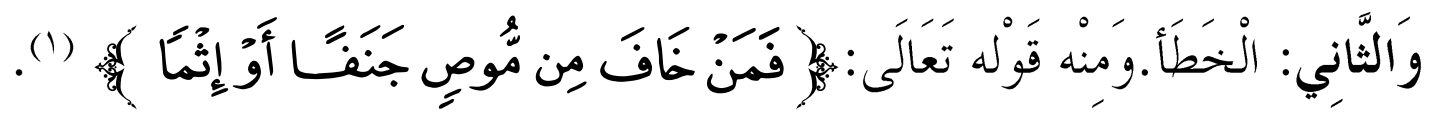

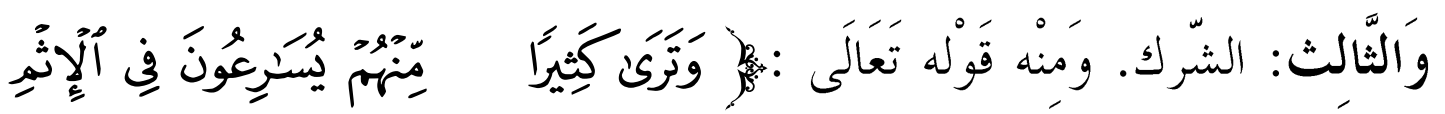

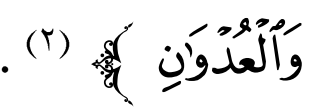

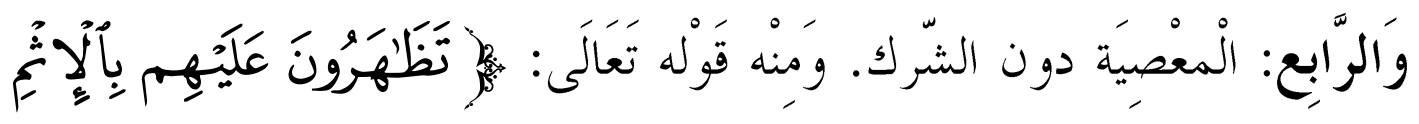

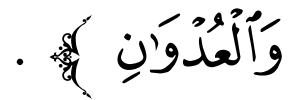

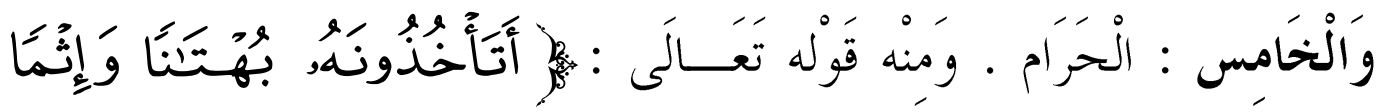

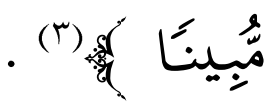

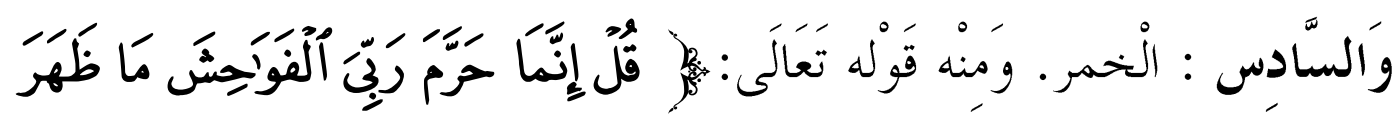

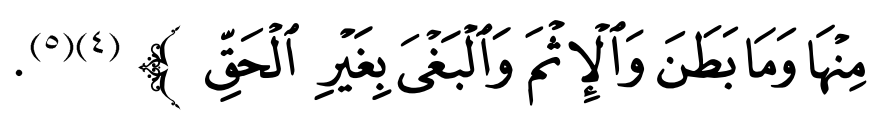

وبالرجوع إلى ماقاله المفسرون تبين أن ظاهر الإثم - في سياق الآية الكريمة -

هو الإعلان بالزنا وباطن الإثم الإسرار به ، ويدل على ذلك السياق الخارجي ،

وهو أن العرب كانوا يستبيحون الزنا، و كان الشريف منهم يتشرف فيسر به ، وغير الشريف لا يبالى فيظهره(ج) ، وقال السدي : أما الظاهر فالزواني في الحوانيت

$$
\begin{aligned}
& \text { (1) من الآية rم /البقرة. } \\
& \text { (r) من الآية r / المائدة. }
\end{aligned}
$$

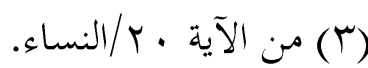

$$
\begin{aligned}
& \text { من الآية سب/الإعراف. }
\end{aligned}
$$

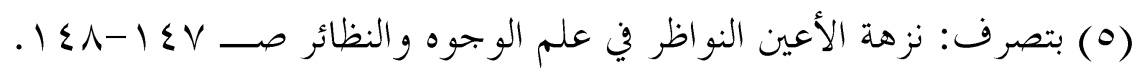

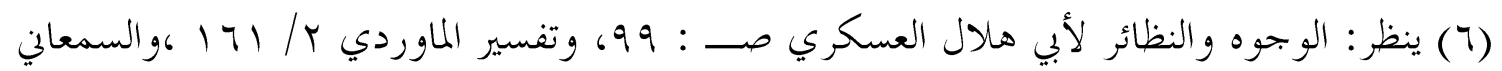


وهن" أصحاب الرايات. وأما الباطن فالمرأة يتخذها الرجل صديقة فيأتيها سرًا،

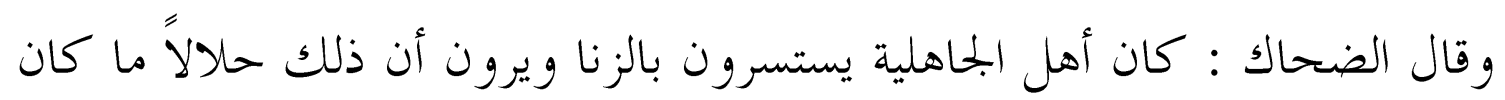
سرًا فحرم الله السر منه و العلانية(1). إذن (( ظاهر الإثم )) يتميز بملمح الإعلان والجهر بعملية الزنا. و (( باطن الإثم )) يتميز .ملمح الإسرار والحففاء بهذه العملية .

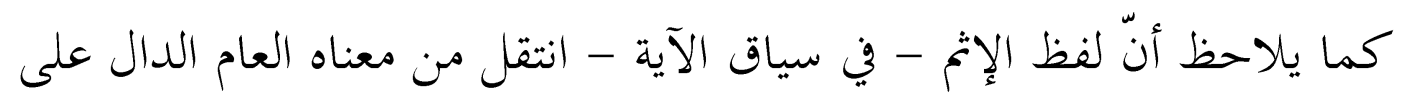
الأفعال المبطئة عن الثواب إلى معنى خاص وهو (( الزنا )).

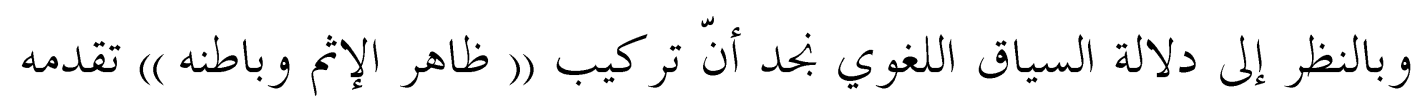

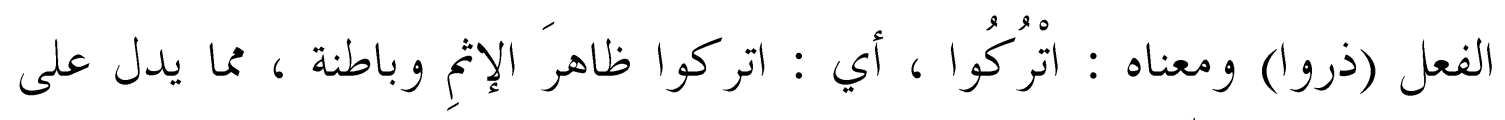
حرمة الزنا في السرِ و العلن.

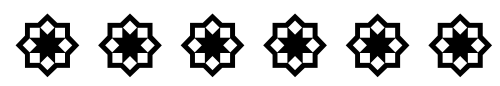




\section{الهبــنْ الرابـه : لفظة : ( الممّم ) : \\ $====1==1==1==1$}

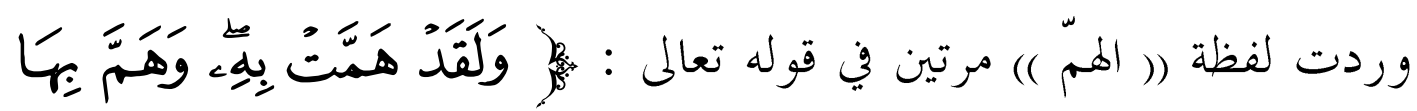

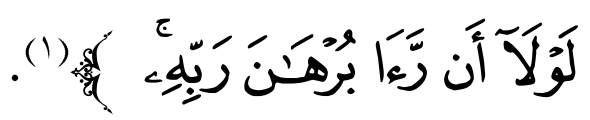

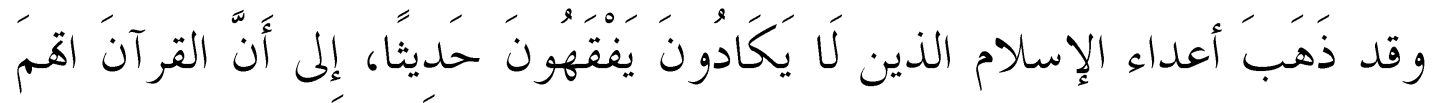

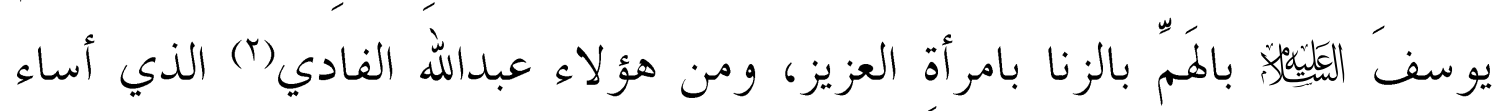

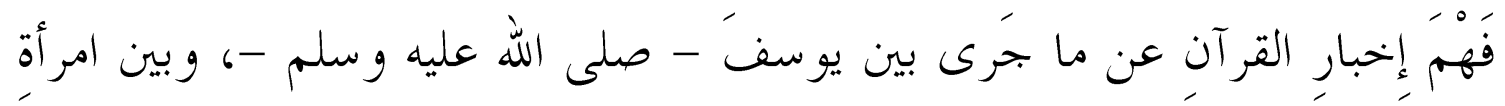
العزيز مستشهدًا على ذلك بما قاله بعض المفسرين من أنّ المراد " قَصَدَتْ مخالَطتَه

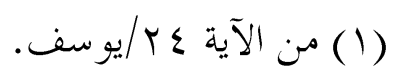

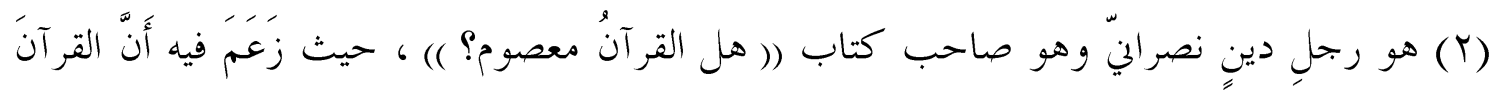

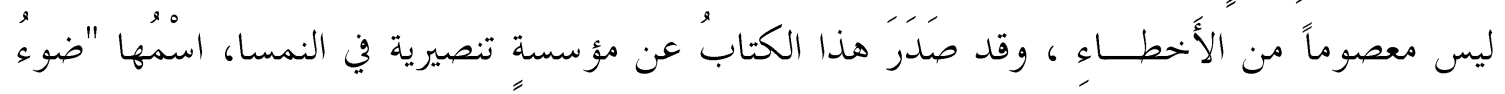

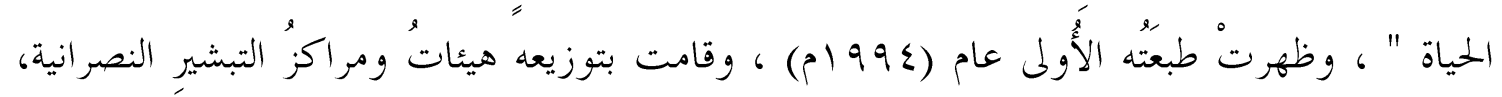

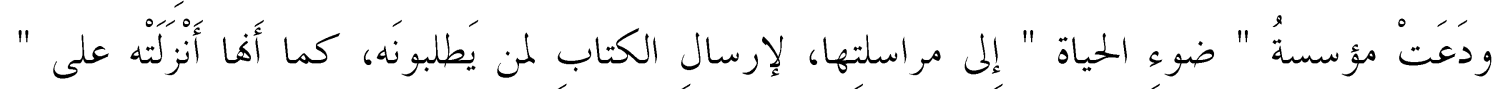

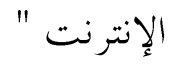




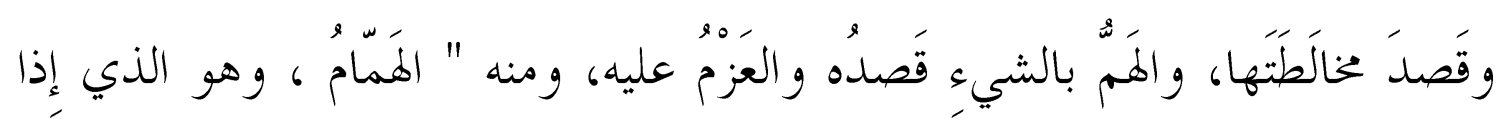

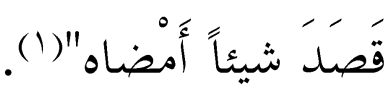

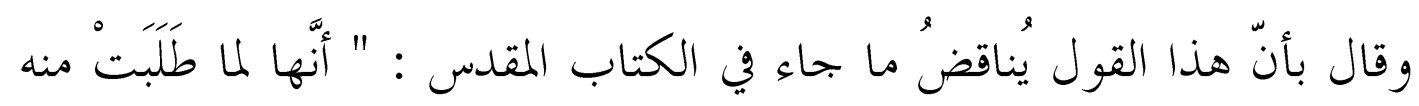

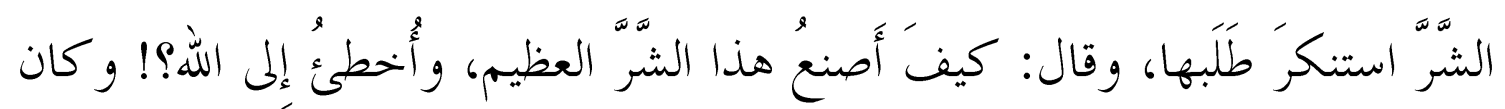

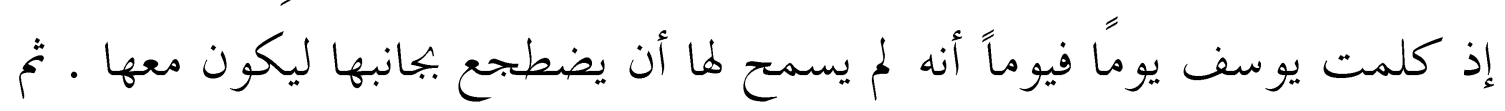

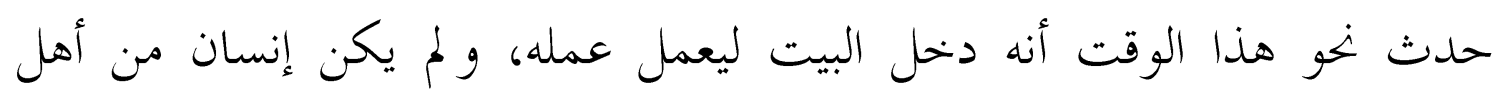

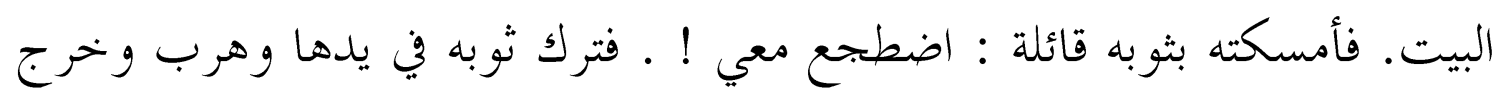

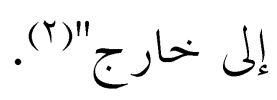
والحق أنّ حديث الكتاب المقدس عن تبرئة سيدنا يوسف - عليه السلام- فما

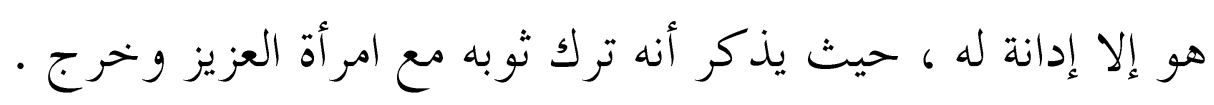

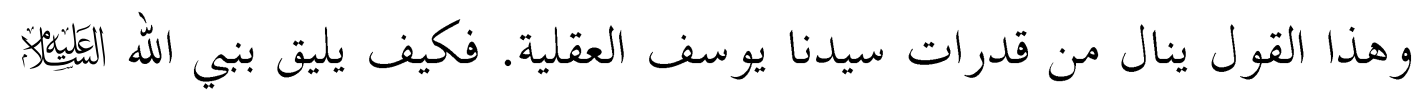

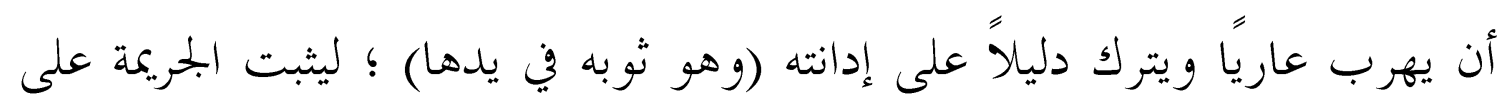

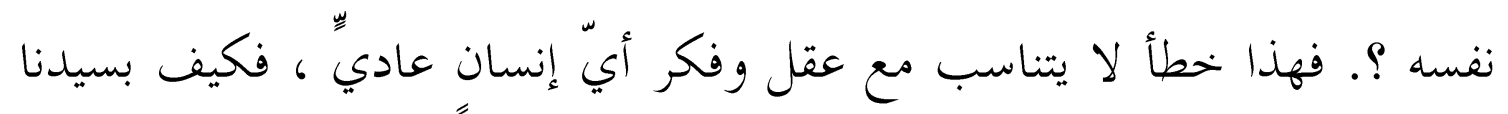
يوسف الئلئلة) وقد عصمه الله في عقله وفكره؟ .

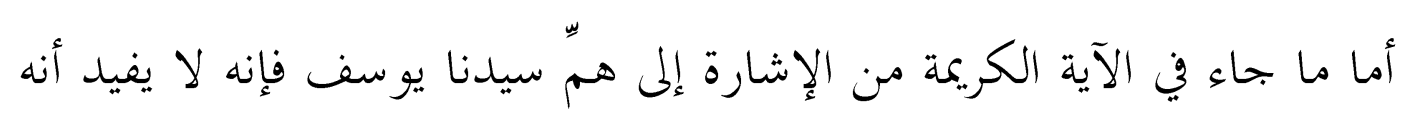

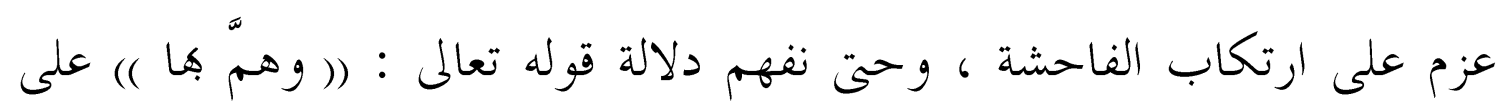

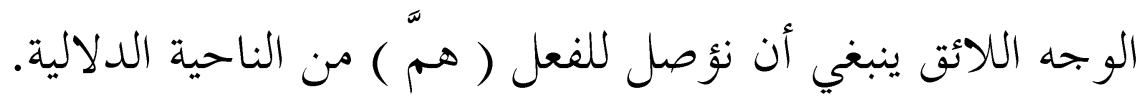

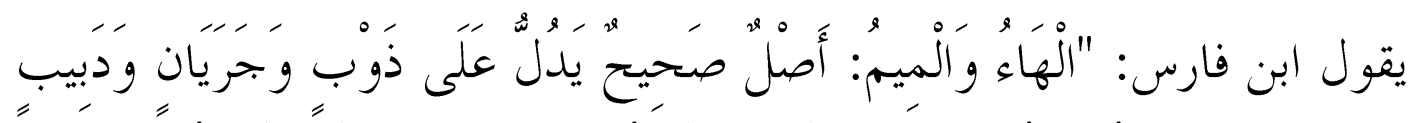

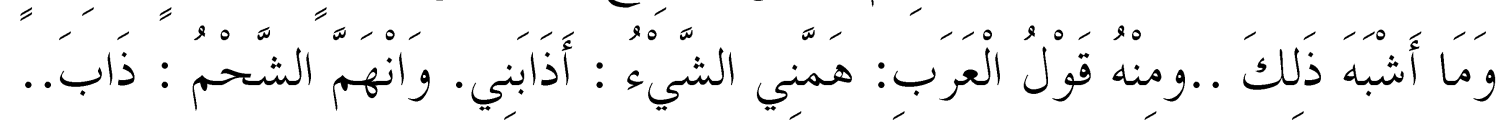
(1) ينظر : تفسير البيضاوي / / ـ 17 ، ، و السراج المنير في الإعانة على معرفة بعض معاني كلام ربنا

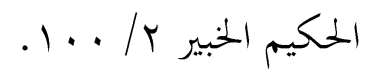

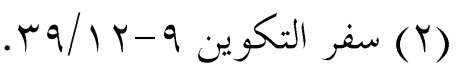




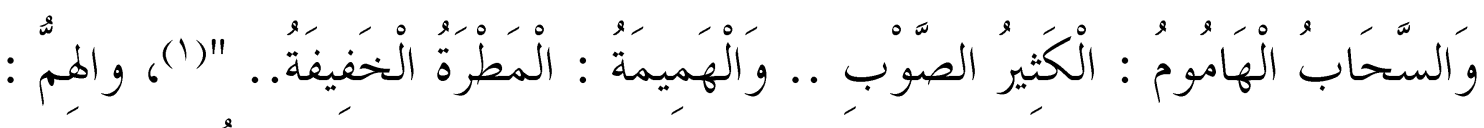

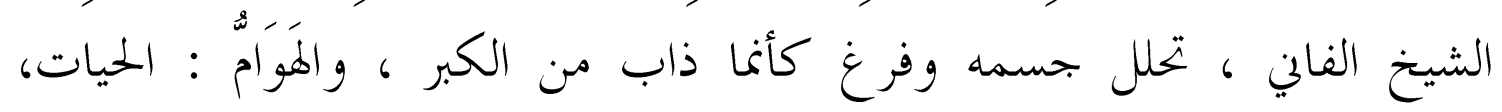

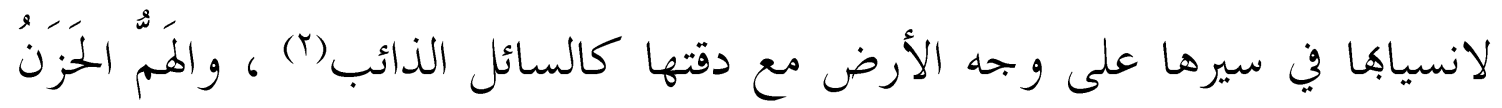

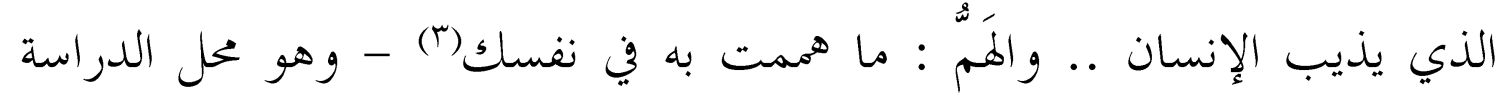

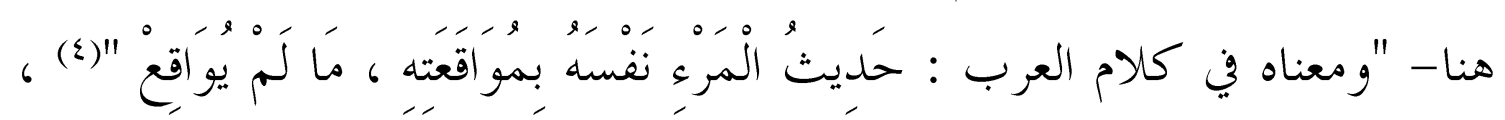
ولعله سمي بذلك ؛ لسرعة ذوبان تلك الخواطر وتحر كها من العقل .

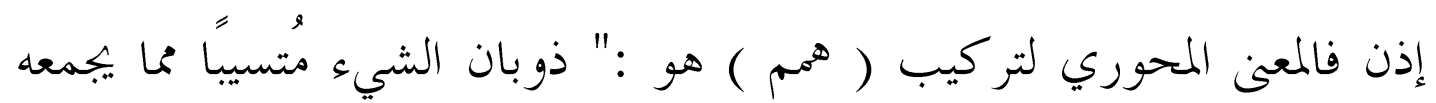
لحرارة أو شدة(0) ، قلت : وهذا هو الأصل الدلالي لتركيب (همم) ، ثم يتفرع منه

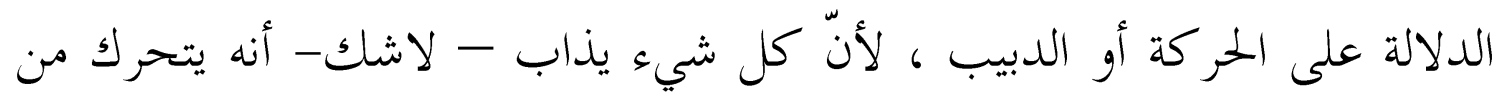

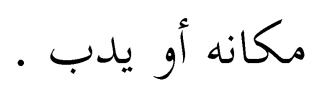

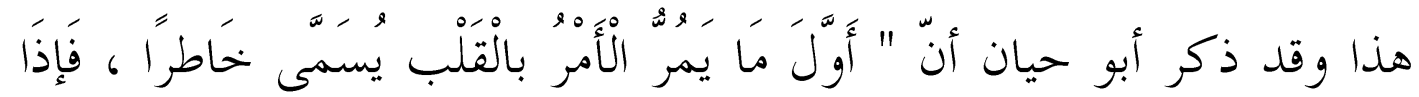

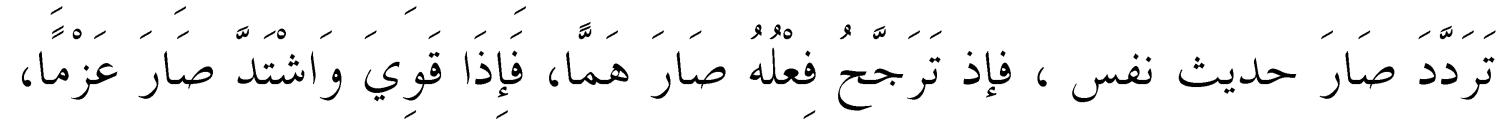

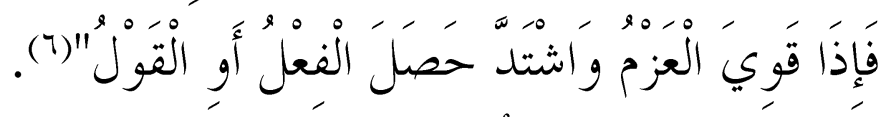

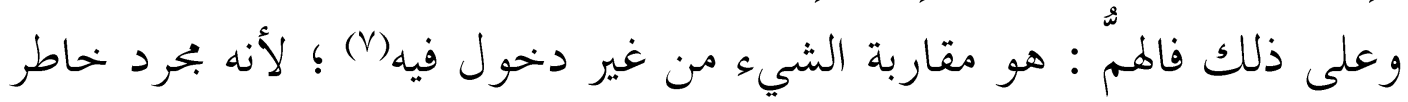
يعترض القلب ثم يذوب ويتحرك ، أو بحرد خطور الشىء في البال ، وإن لم يقع

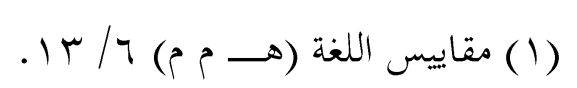

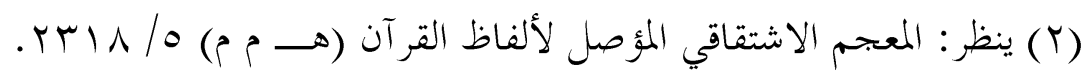

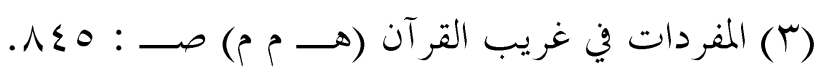

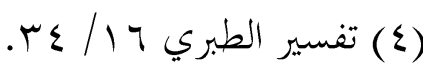

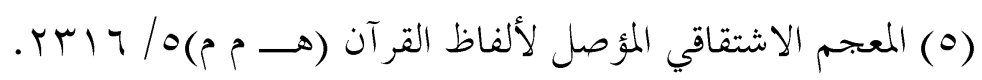

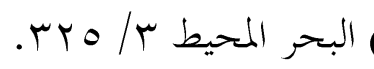

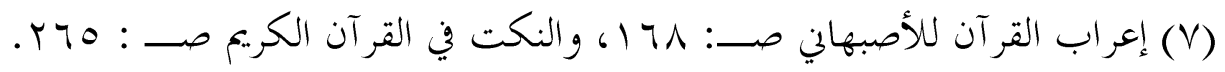




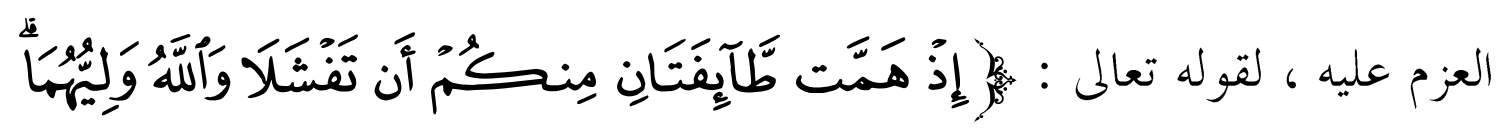

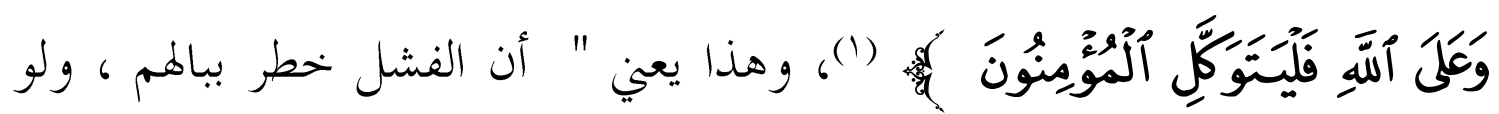

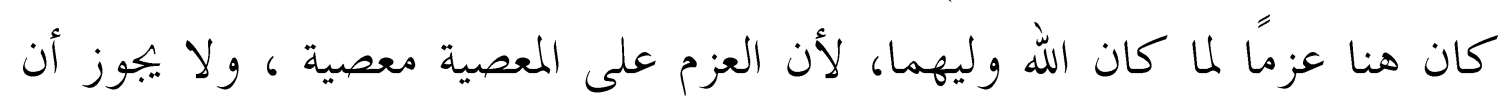

$$
\text { يكون الله ولي من عزم على الفرار "(r). }
$$

وهذا بخلاف"العزم الذي هو تصميم القلب على الشئ، والنفاذ فيه بقصد ثابت.

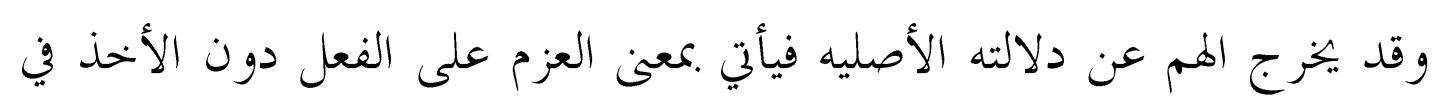

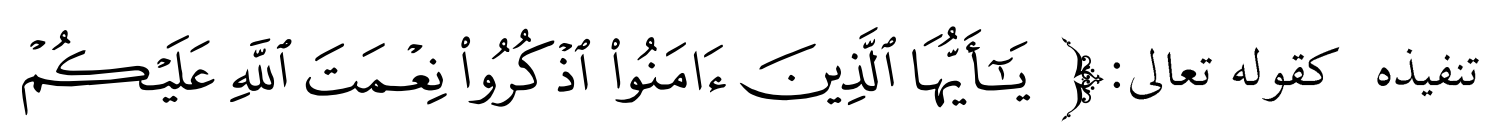

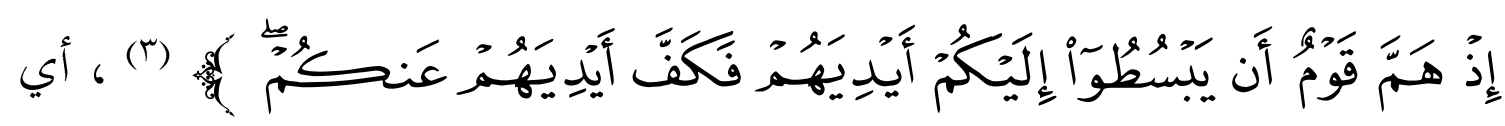

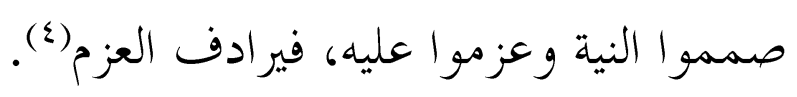

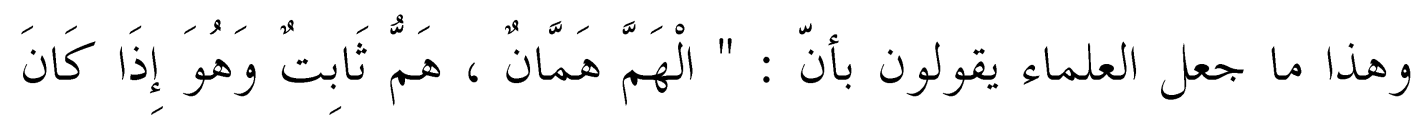

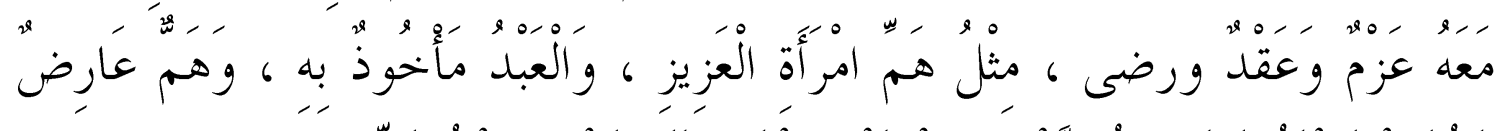

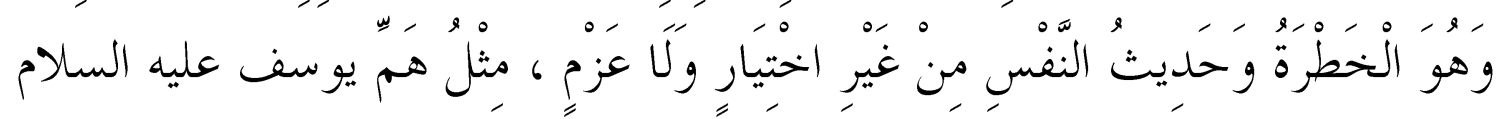

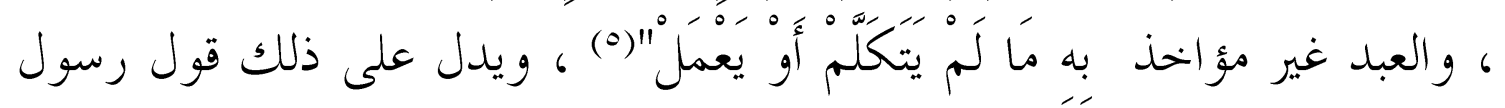

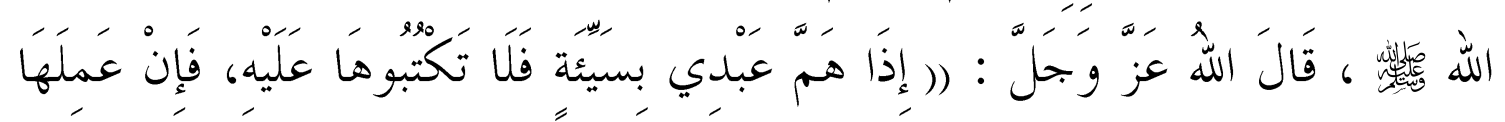

(1) الآية r / (1/Tل عمران.

$$
\begin{aligned}
& \text { (r) الفروق اللغوية صـ : (roV-roT. } \\
& \text { (r) من الآية ال//(المائدة. }
\end{aligned}
$$

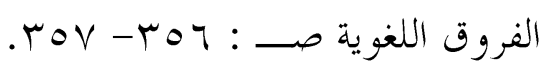

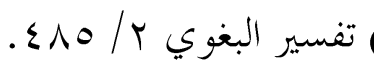




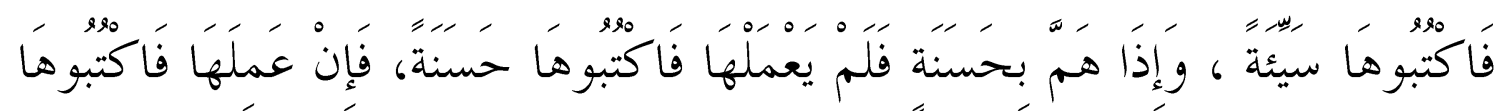

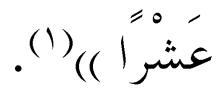
وقد روُوي عن ابن المبارك أنه قال : قلت لسفيان: أيؤخذ العهد بالهمّة؟ قال: إذا

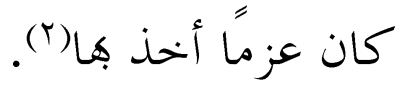
و لم يفهم أعداء الإسلام هذا الفرق الدلالي وجهلوا وتحاهلوا دور السياق في

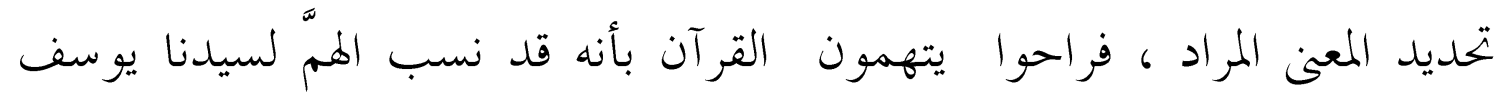

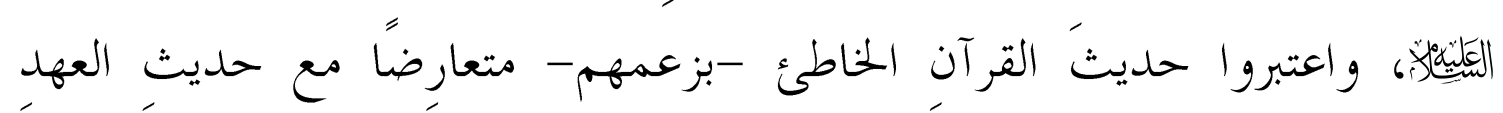
القلسيم الصائبِ في نظرقهم. فالذي يجعلنا نفرق بين الهمَّّن في سياق هذه الآية الكريمة هي معطيات السياق

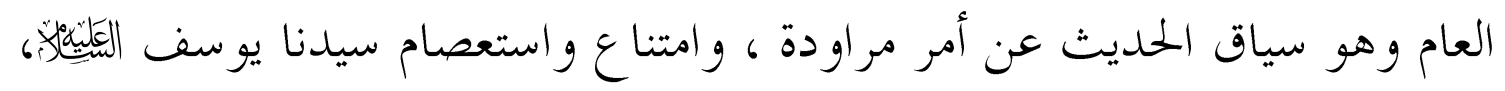
و اقتضى ذلك الأمر مفاعلة بين اثنين يتصارعان في شيء. فالهم منها معناه: العقد و العزم و الرضى ، و وقد دلّ على ذلك معطيات السياق وهي :

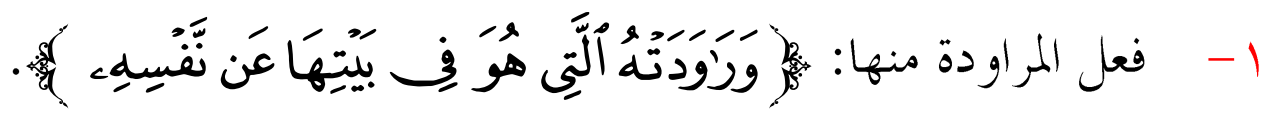

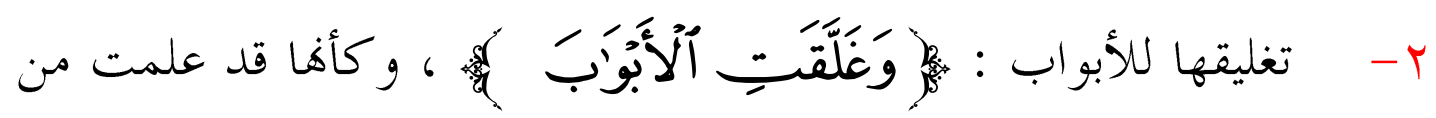
طول صحبتها له أنَّه لن يستجيب لهذه وعله الجريمة الفظيعة فعمدت إلى ولى

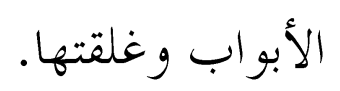

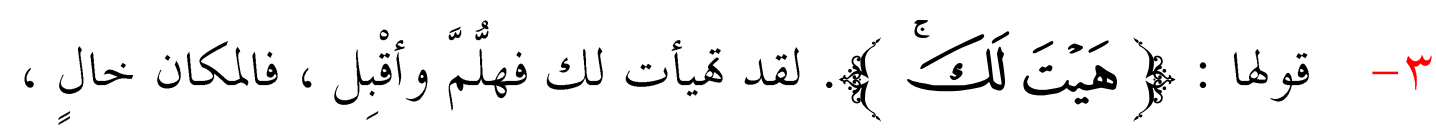
وليس هناك من ينغص خلوتنا.

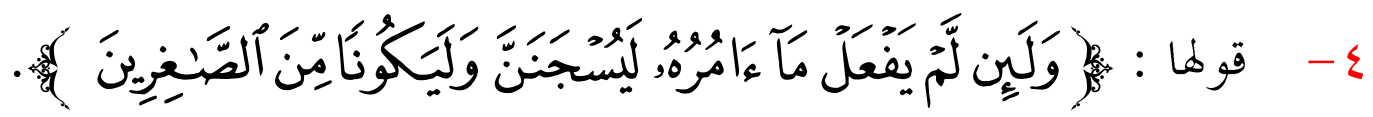

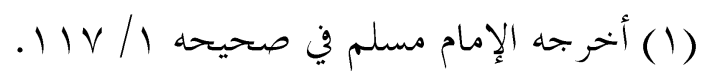

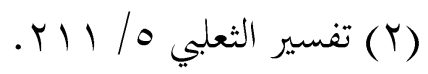


في حين أنَّ الهمّ من سيدنا يوسف عليه السلام كان مجرد همٍٍ عارضٍٍ وهو

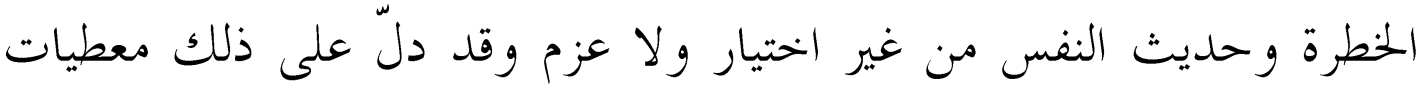

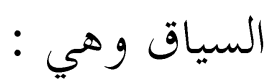

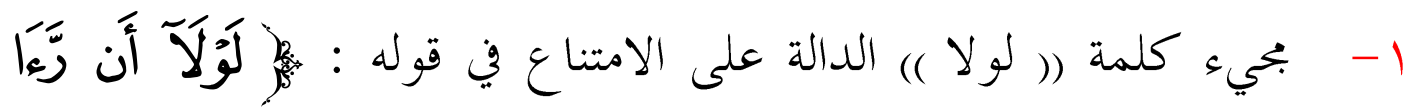

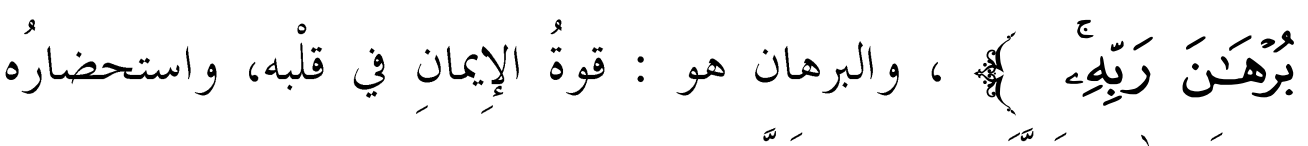

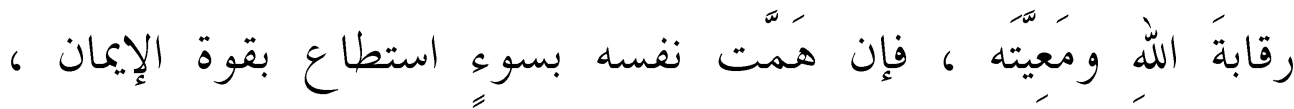

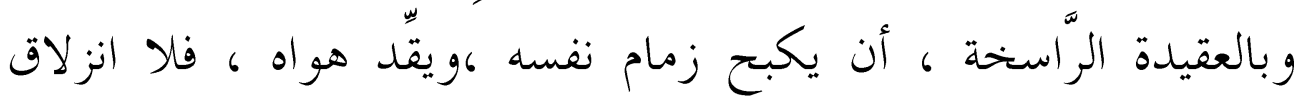

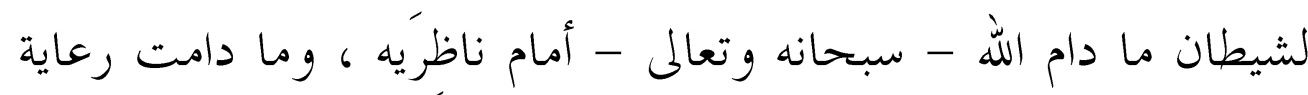

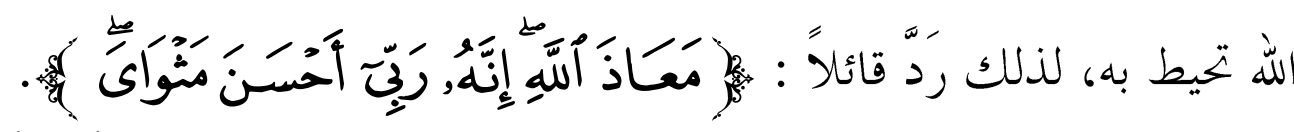

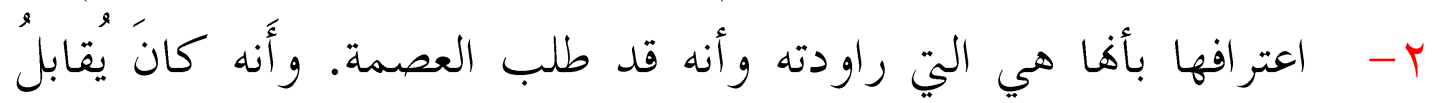

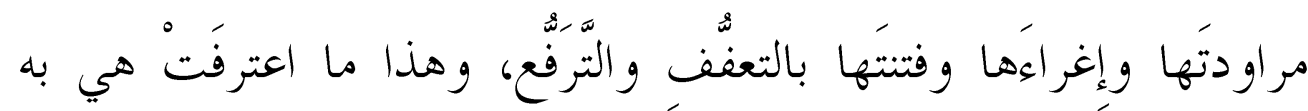

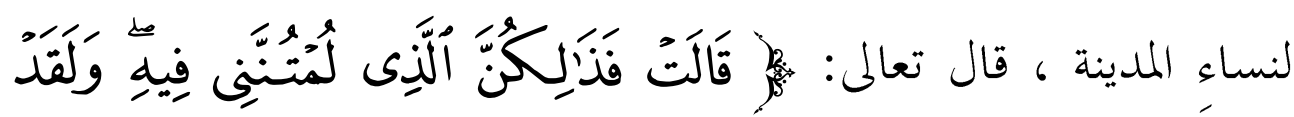

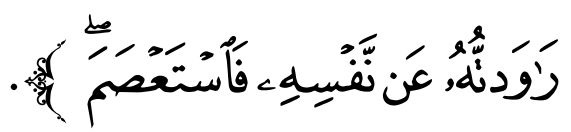

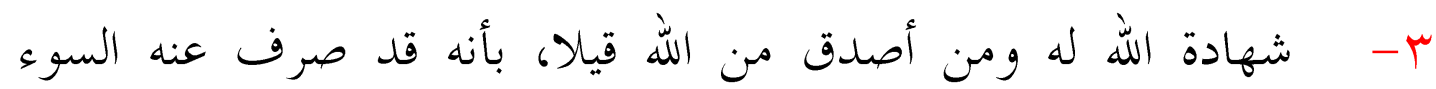

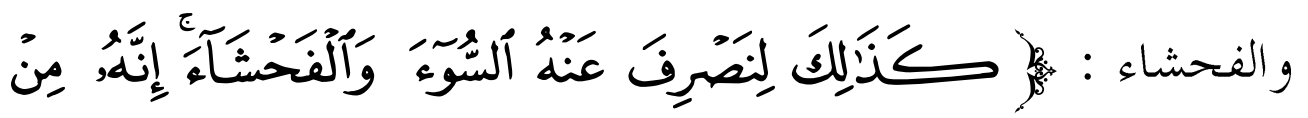

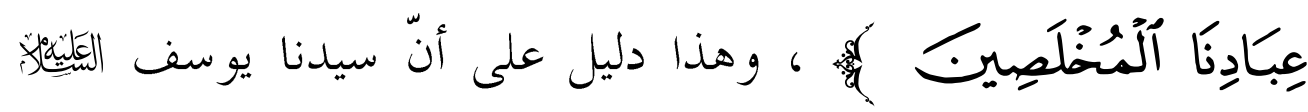
معصوم لم يذهب إلى السوء والفحشاء ، فقد كان كالجبل الثابت في

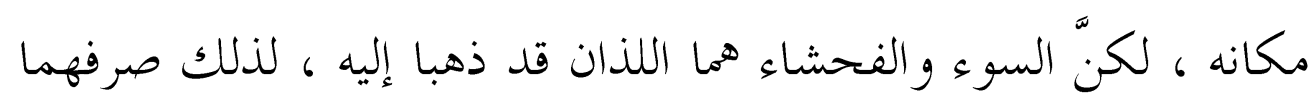

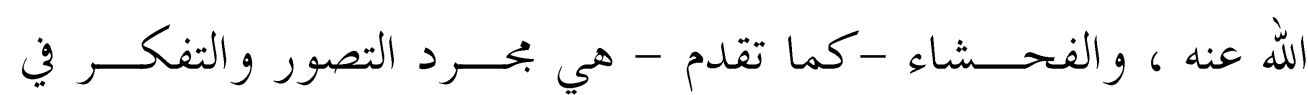


(( الفاحشة )( ) فإذا كان الله قد صرف عنه تصور الفاحشة فمن باب أولى أن يصرف عنه الفاحشة نفسها.

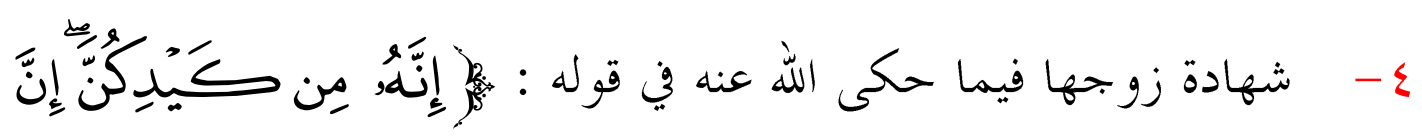

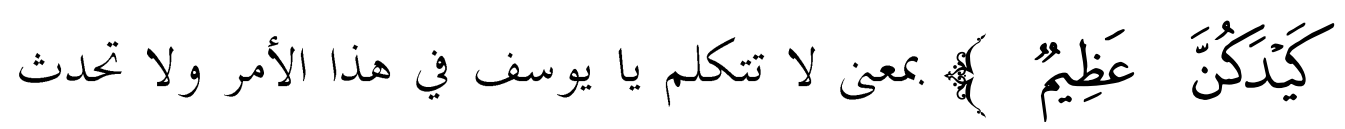

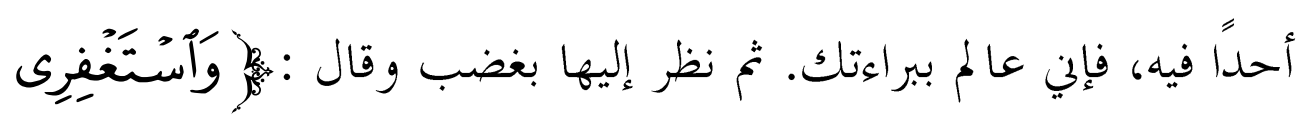

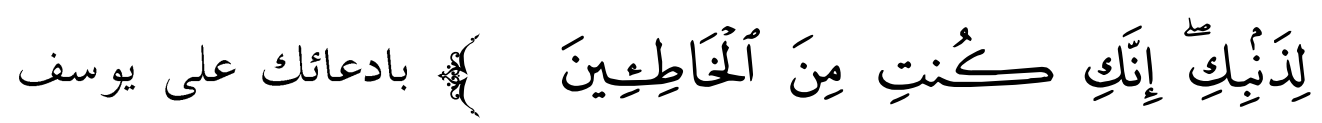
و إسنادك الفعل إليه.

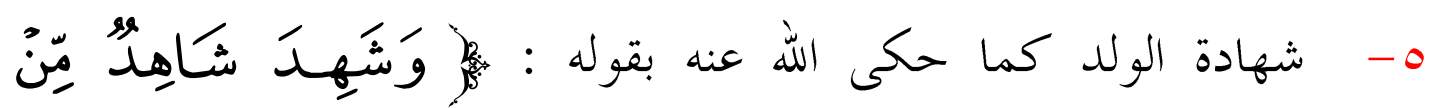

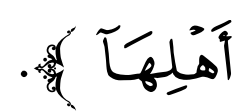

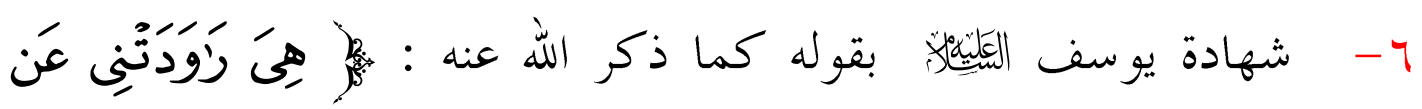

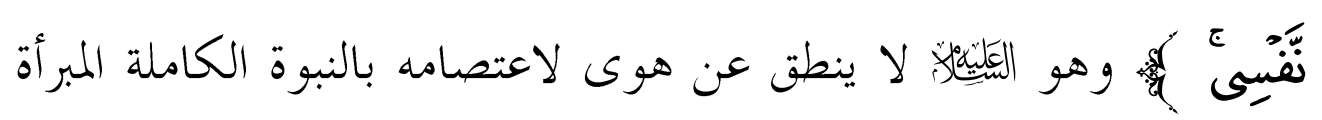
من كل عيب. - V

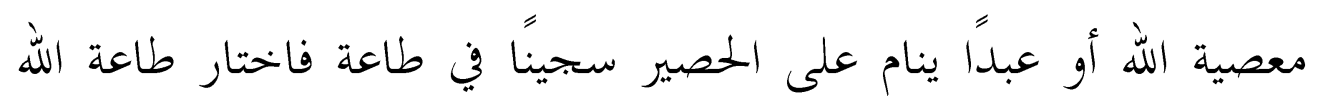

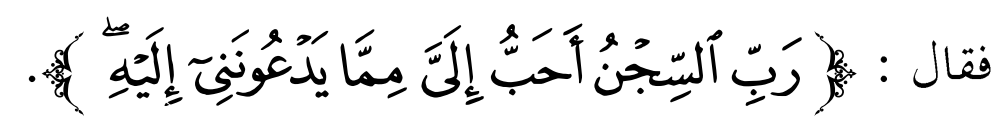

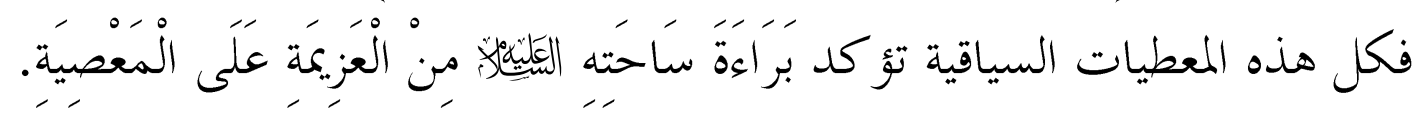
إذن الهم في حق سيدنا يوسف هو بحرد خاطر أو حديث نفس بدليل أنه طلب

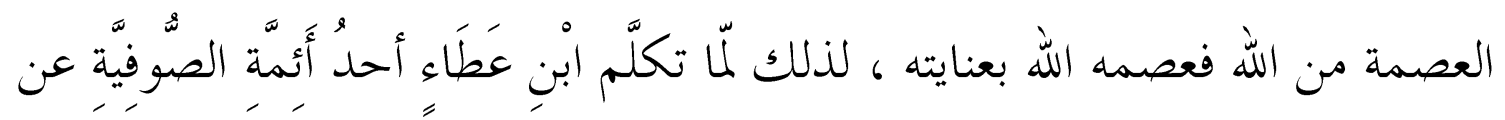




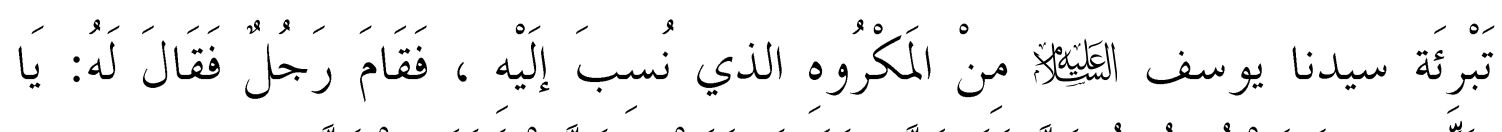

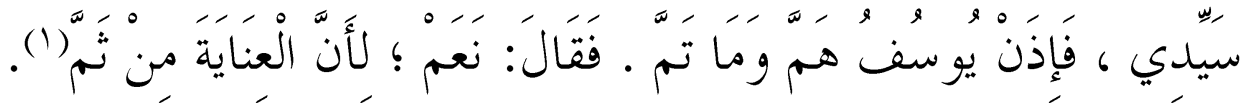

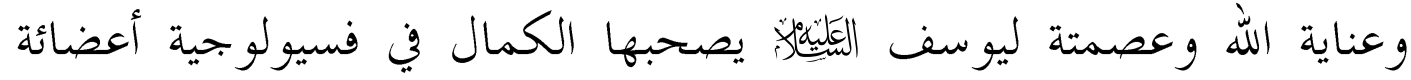

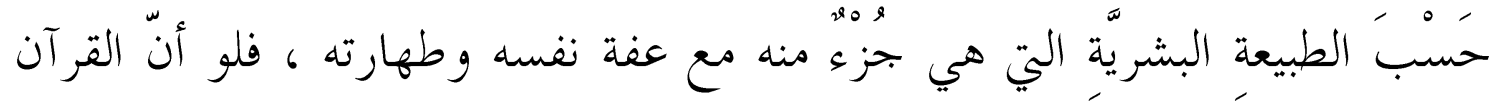

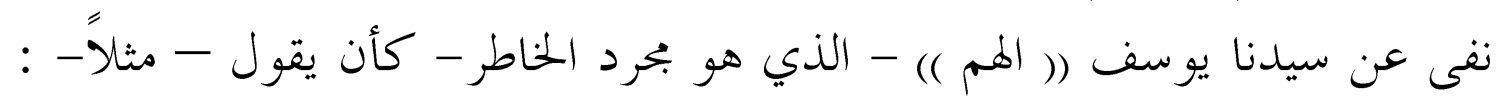

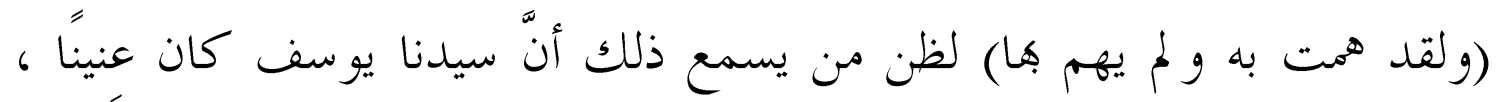

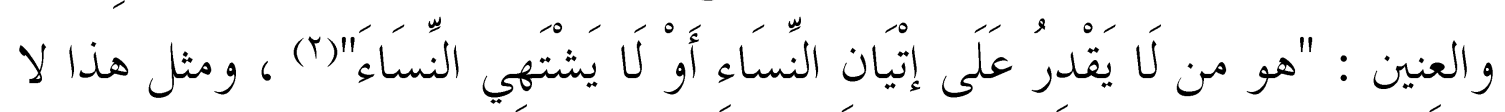

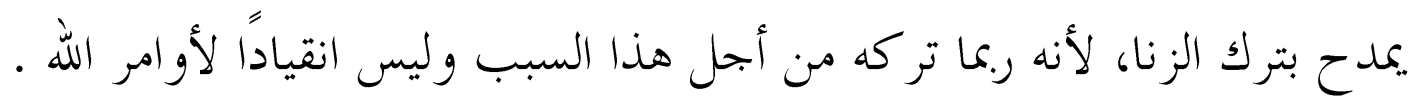

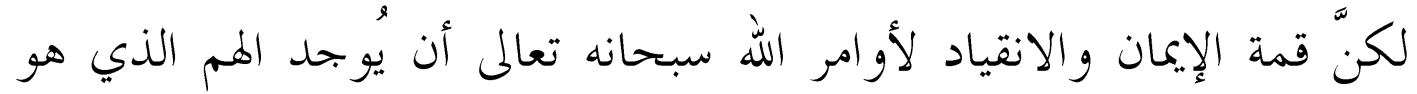

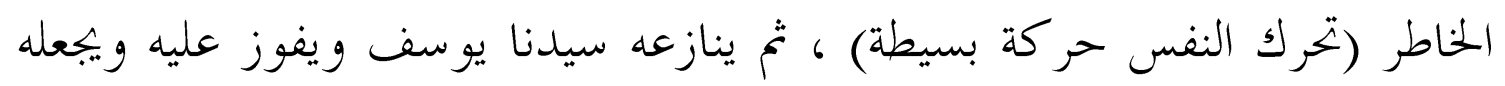
يذوب ولا يبقى منه شيء ، وهذا المعنى يتفق مع المعنى الدلالي الذي تدور عليه

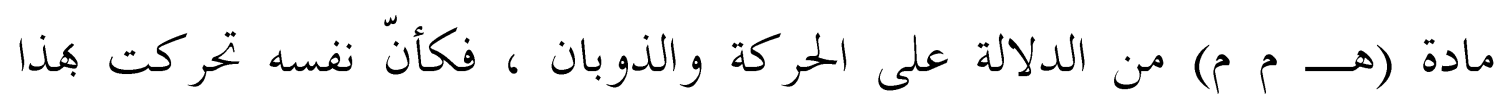

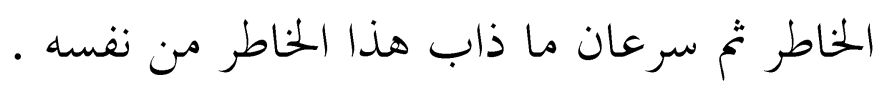

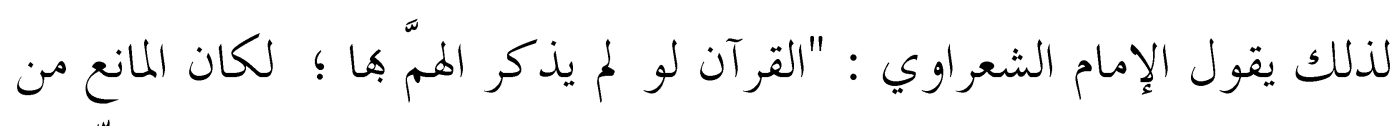

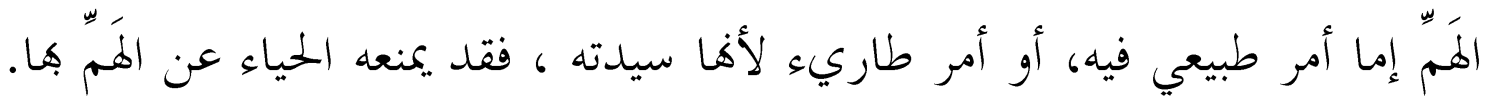

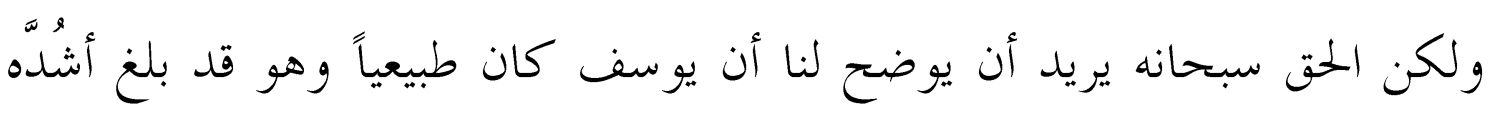

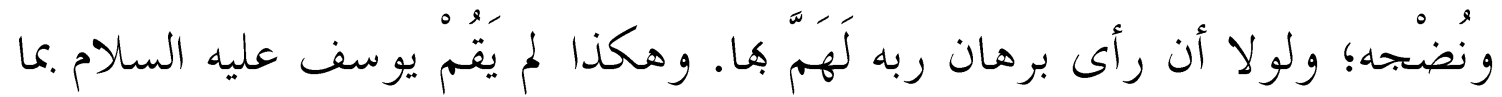

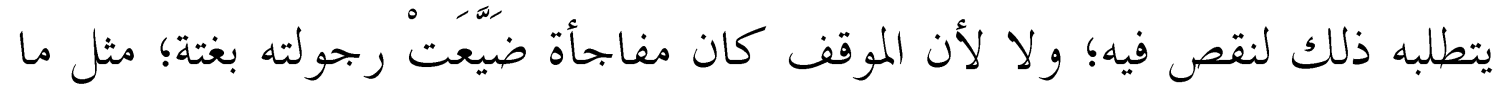

$$
\begin{aligned}
& \text { (1) ينظر: أحكام القرآن لابن العربي r/ V Vـ. }
\end{aligned}
$$

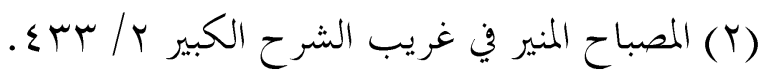


يحدث لبعض الشباب في ليلة الزفاف ، حين لا يستطيع أن يَقربَ عروسه؛ وتمر أيام

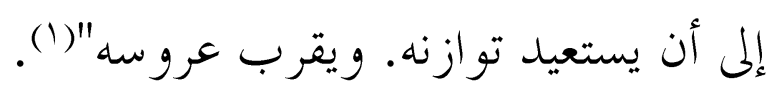

ومما يؤيد هذا المعنى قوله حينما رأى إحاءات وإثارات أعين النسوة - اللاتي

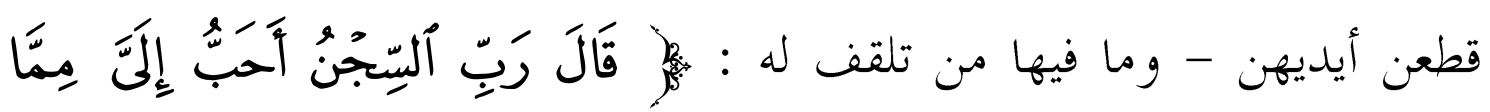

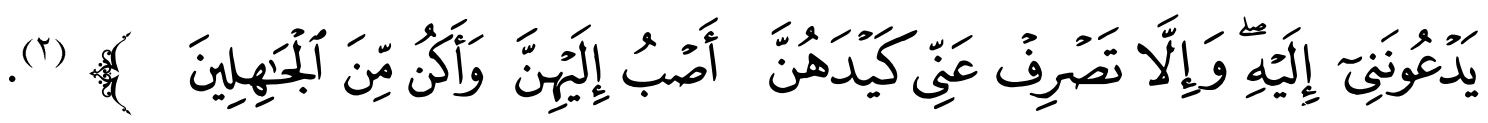

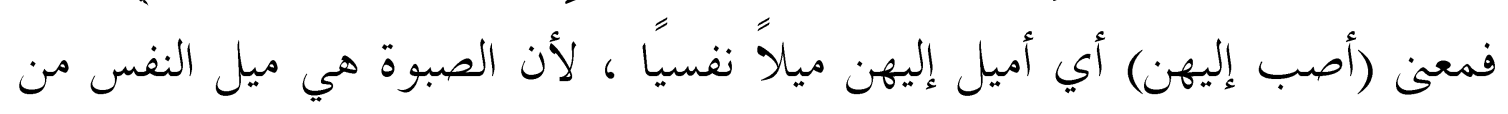

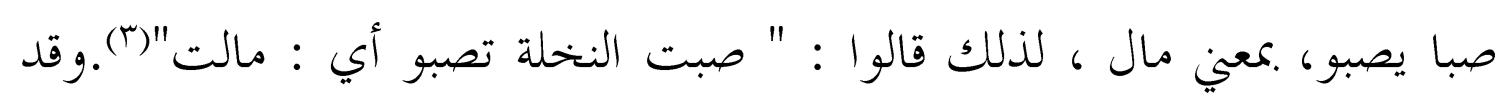

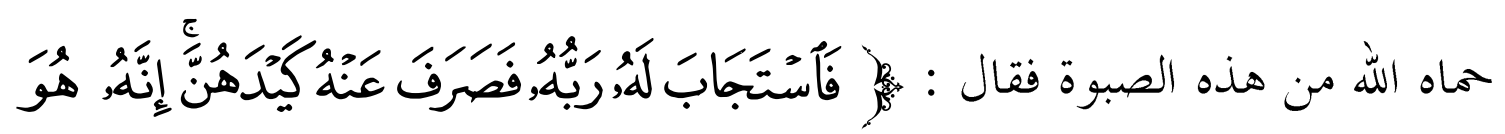

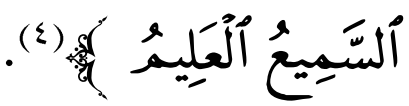

فيتبين مما سبق أنّ القرآن الكريم قد بلغ قمة الإعجــاز الدلالي في اختيار لفظة

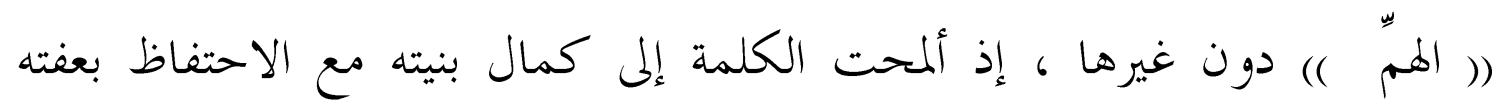

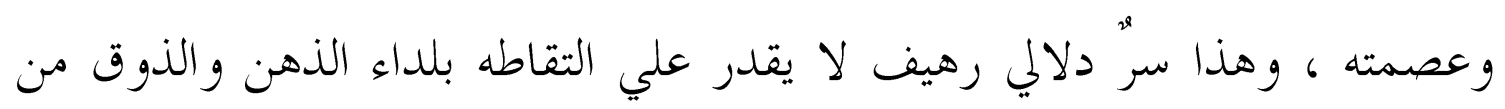
هؤلاء المشككين. هذا وقد اختار أبو حيان -رحمه الله- أنّ يوسف لمُ يقع منه هم البته ، وأوّل

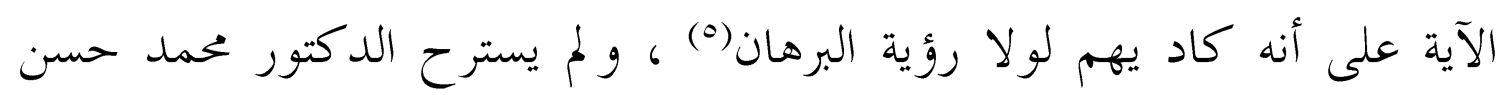

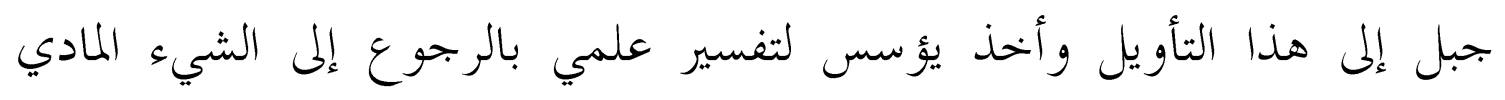

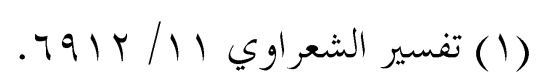

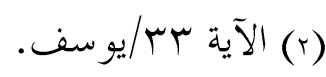

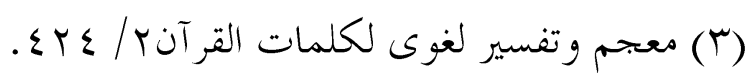

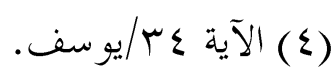
(0) البحر المحيط في التفسير ToV/T. 
المحسوس مطبَّقا ذلك على الأصــل الدلالي للكلمة وهو (( الذوبان )) ، فذكـــ

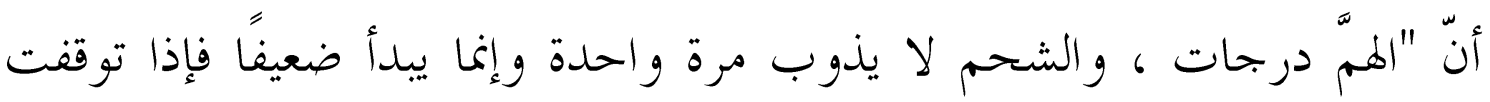
الإذابة جمد . . وقد قالوا (( الهَميمة : المطر الضعيف الهين .. )) فهو عليه السلام هم

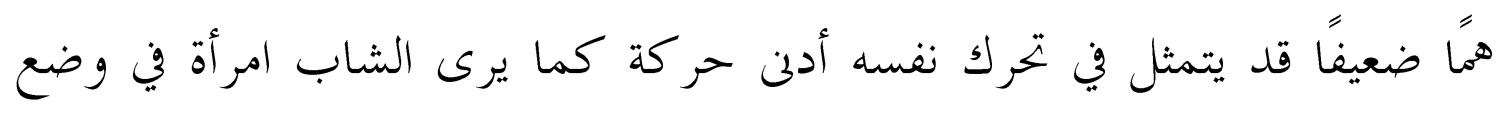
بالغ الإثارة فجأة ، ثم قد يتنبه للرشد بعد استيعاب الموقف ـ أما هي فكان همها

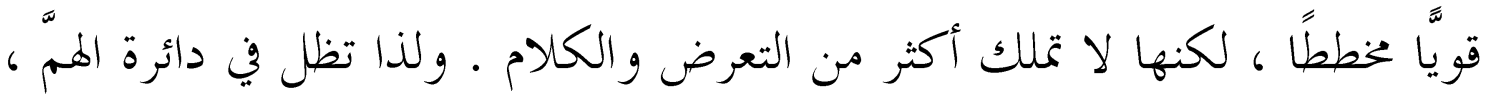

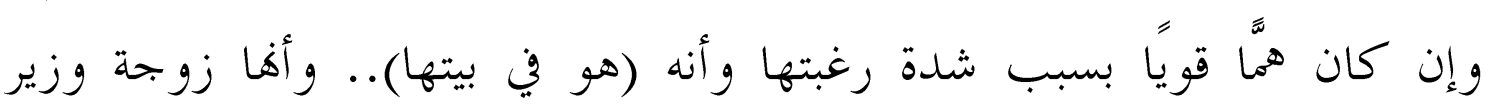

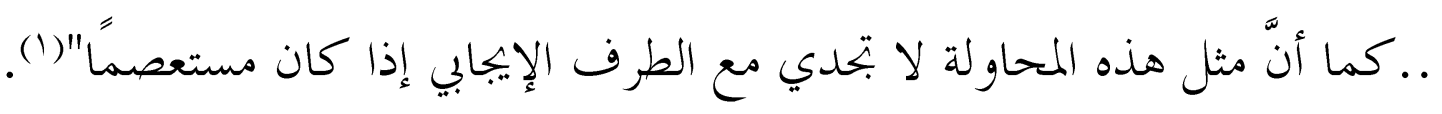

\section{يستنتج مما سبق ما يأيتي:}

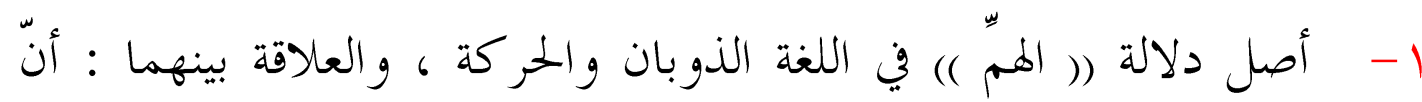

$$
\text { الشيء إذا ذاب تحرك من مكانه. }
$$

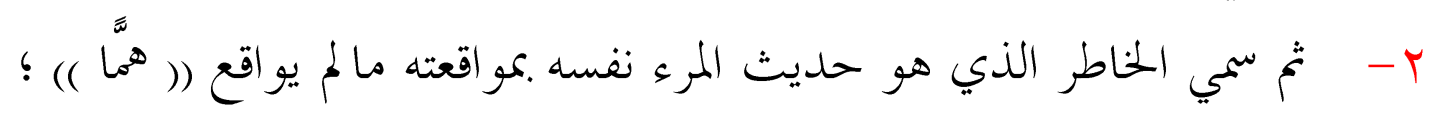

$$
\text { لسرعة ذوبانه وتحر كه. }
$$

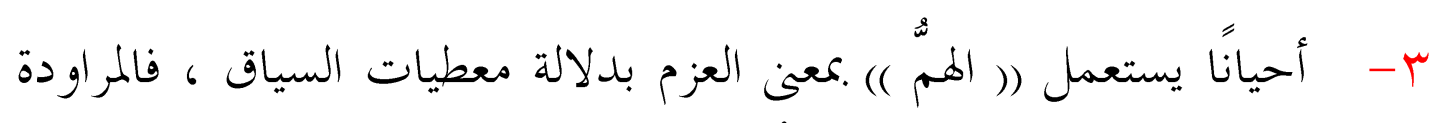

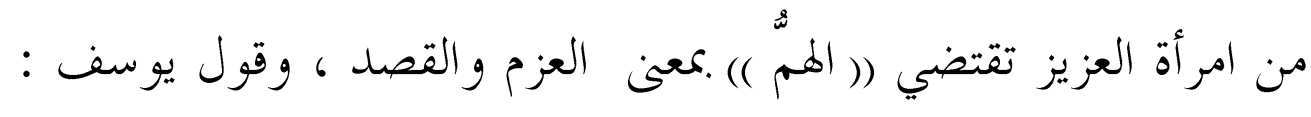

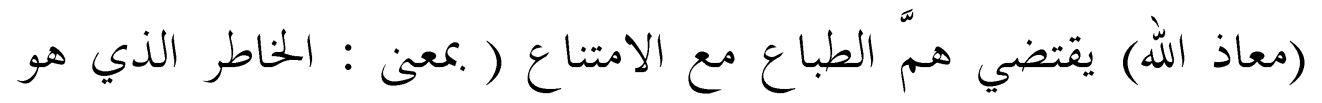

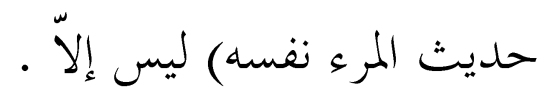

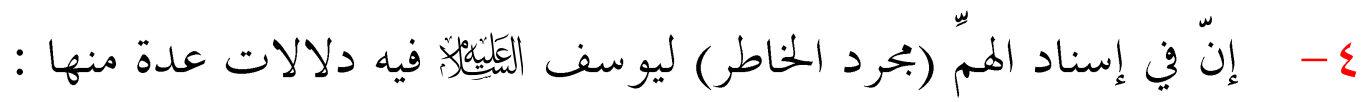
- - كمال طابعه البشري من ناحية فسيولوجية الأعضاء. 
- عدم اهتزاز شخصه النبوي أمام تلك المرأة مع امتلاكها مقومات

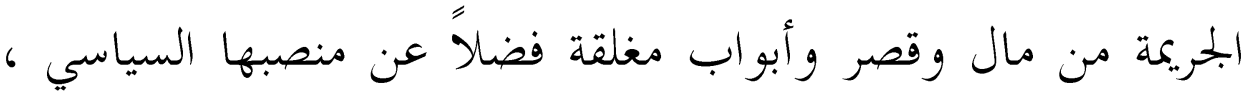
وعلى الرغم من ذلك لم تضعف قواه أمامها و لم يهتز من الناحية

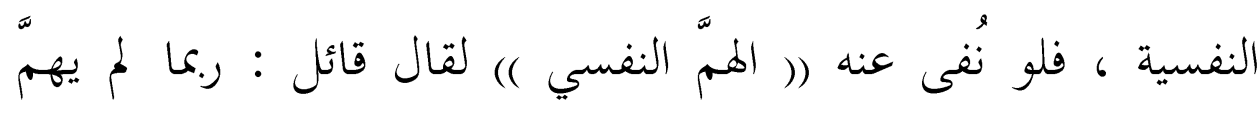
لضعف في بدنه أو نفسه. - إنَّ في إسناد الهمّ النفسي له و امتناعه عن فعل تلك الفاحشة مع قدرته

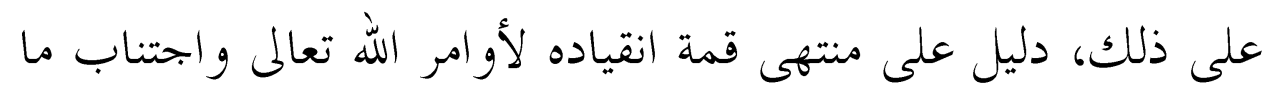

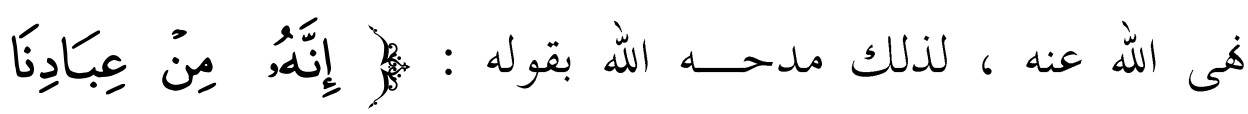

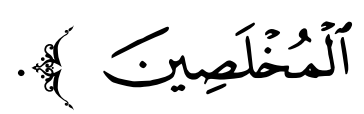
0- - إنّ هذين الفعلين : (همّت ، همّ ) " يختزنان هددف الأدب كلّ تفاصيل

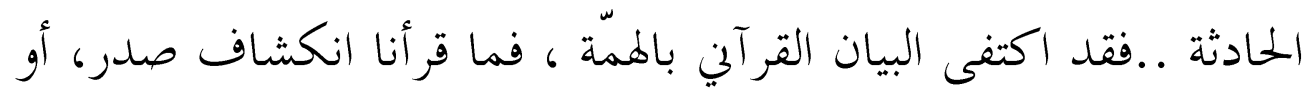
نزع ثياب ..كما هي الحال في كثير من الأدب الروائي، مما يثير الغرائز

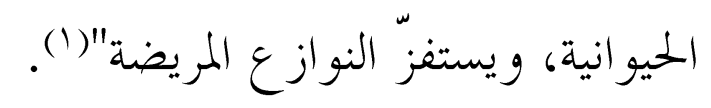

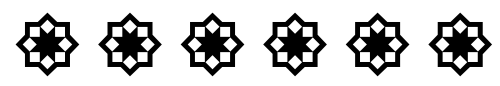

\section{المبـنْ الفامستر : في دلالة لفظة : (السوء) :}

\section{$=\mathrm{E}=\mathrm{=}=\mathrm{=}=\mathrm{=}=\mathrm{=}=\mathrm{=}=\mathrm{=}=\mathrm{=}=$}

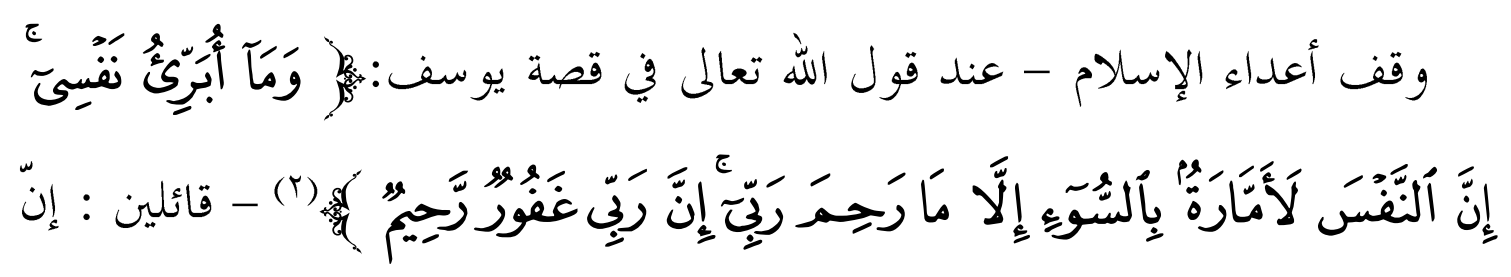

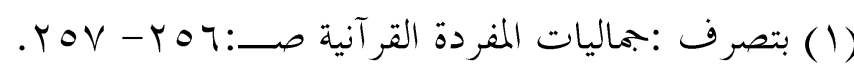

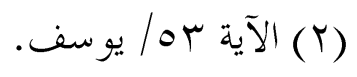


القرآن يتهم نفس يوسف بأهنا شهوانية أمّارة بالسوء وهو الزنا ، فكيف لا يبرى

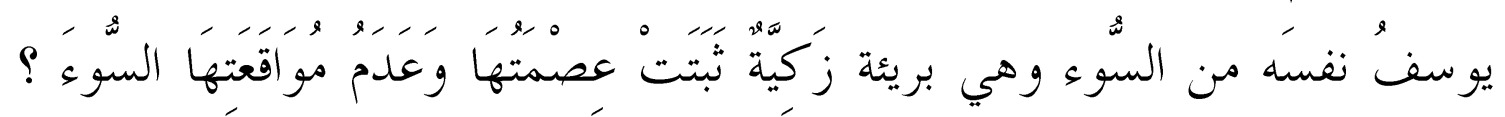

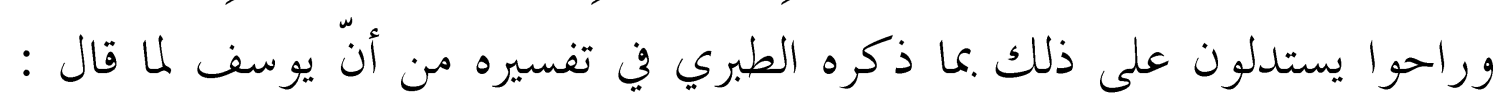

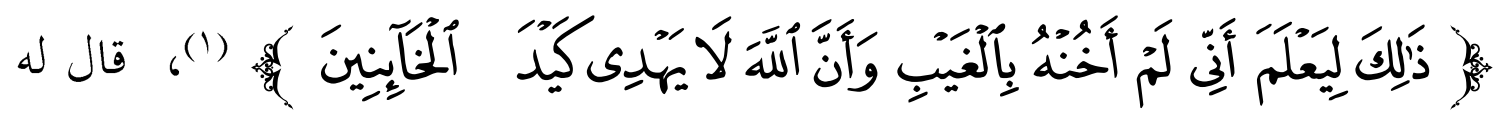

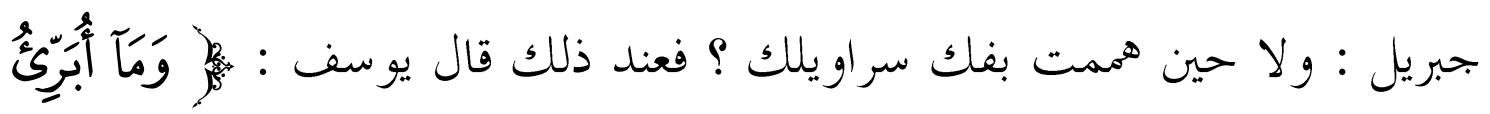

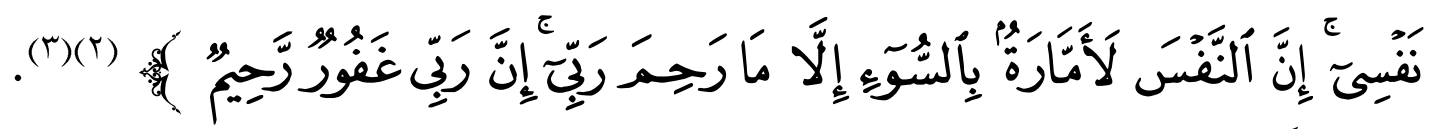
وللرَّد على هذه الشبهة كان لابد من معرفة الأصل الدلالي لكلمة (السوء) ومعرفة دلالتها في السياقات التي وردت فيها في جوِّ هذه القصة .

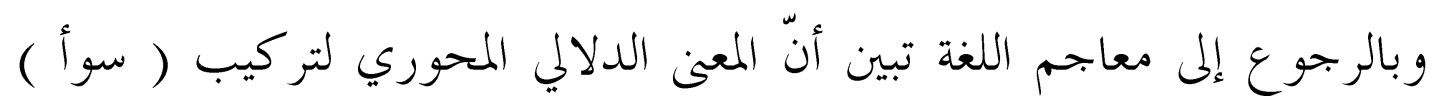

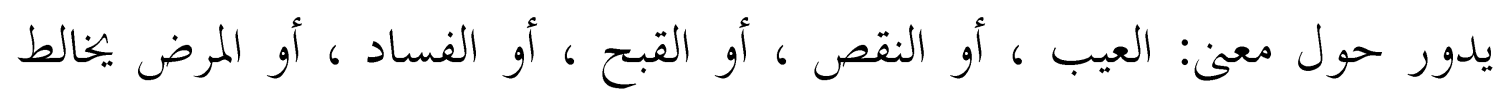

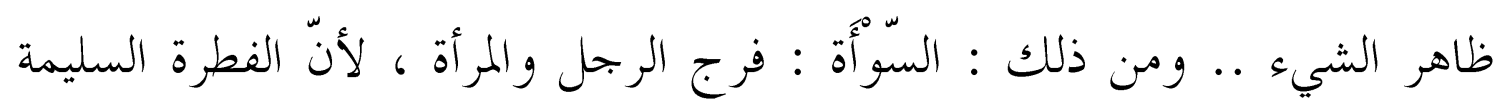

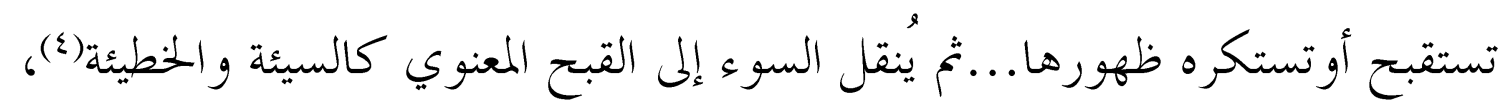

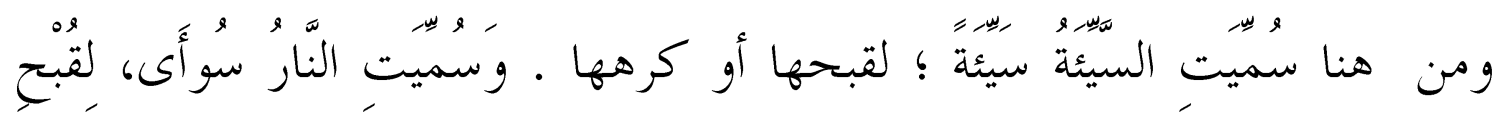

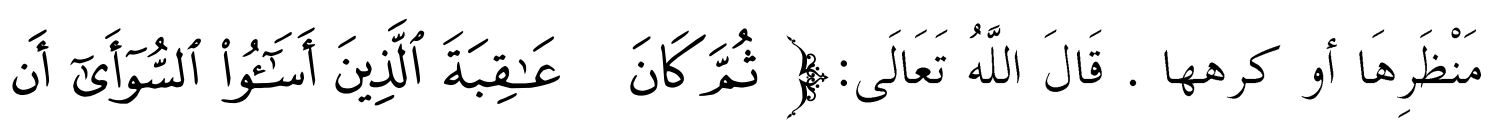

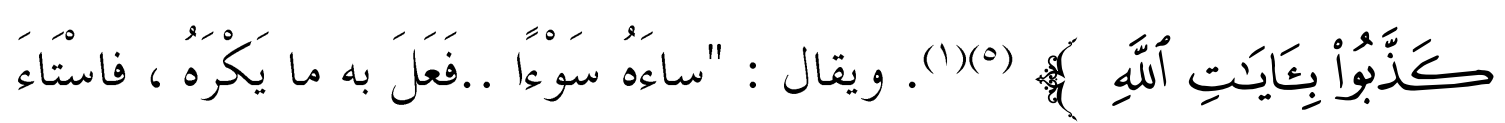

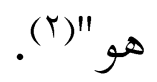

$$
\begin{aligned}
& \text { (1) (1) (آلية ايوسف. }
\end{aligned}
$$

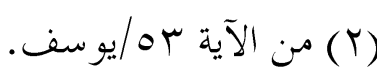

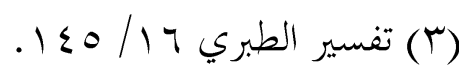

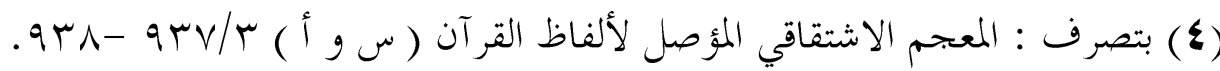

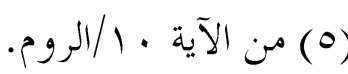


والسوء لفظُّ جامع لكل ما يُتهَمُ به الإنسان من الأمور الدنيوية و الأخروية.

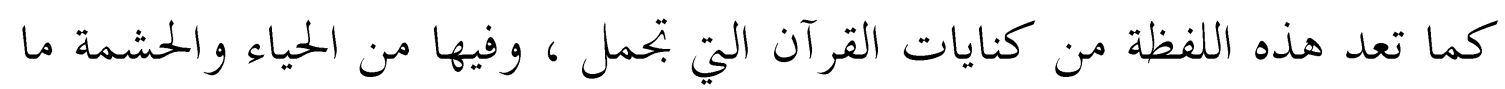
فيها هذا وقد وَذكر أهل التَّفسير أَنْ ( السوء ) جاء فِي الْقُرْآن على أحد عشر

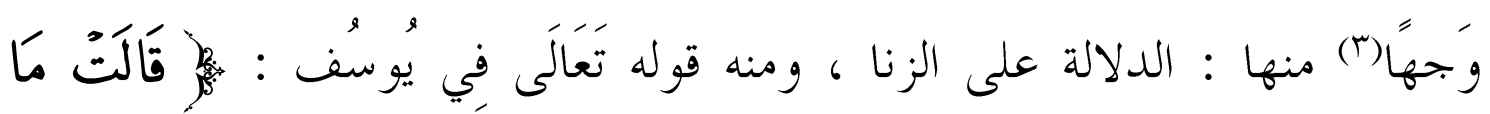

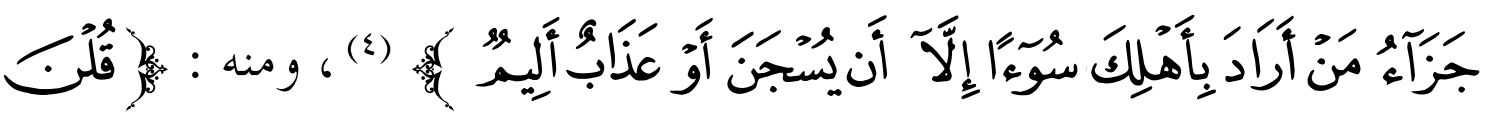

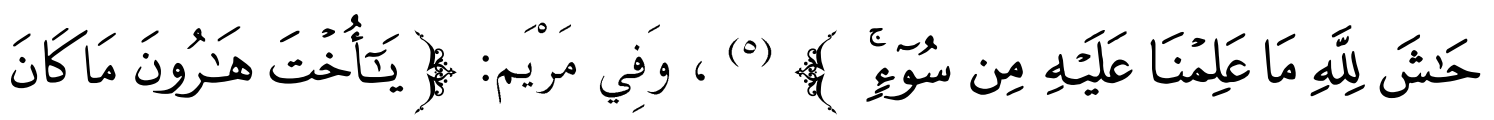

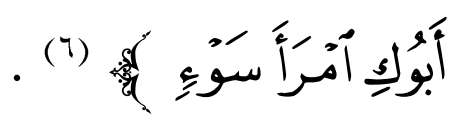
وهنا يلاحظ أنّ الملمح الدلالي المميز للفظ السوء في دلالته على الزنا ، هو

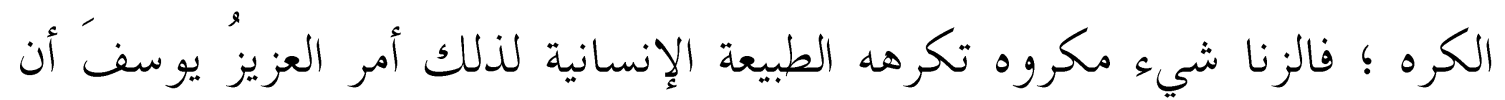

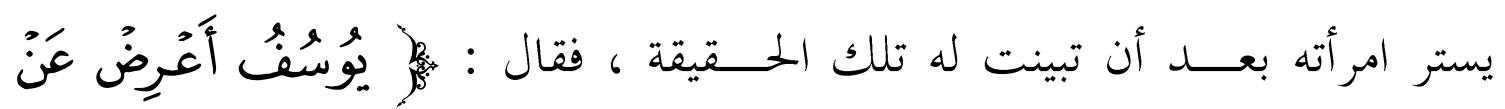

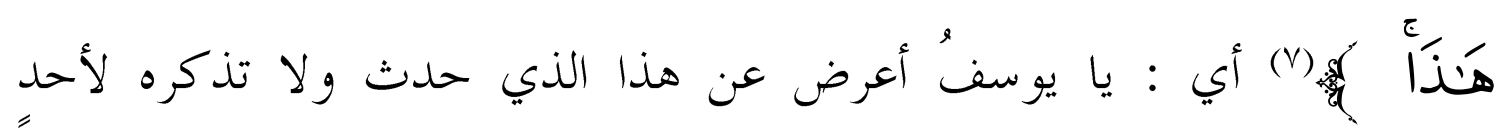

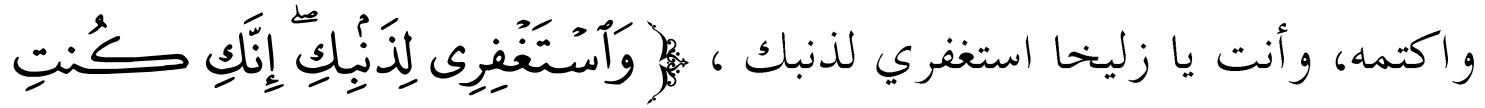

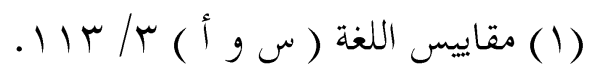

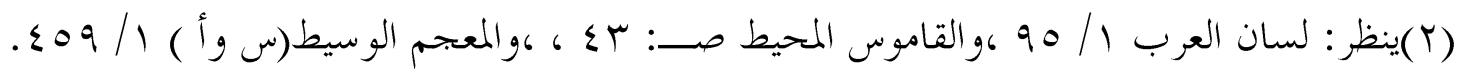

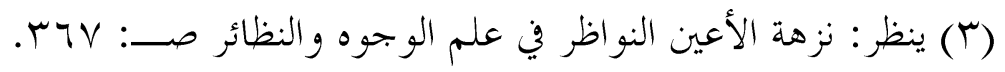

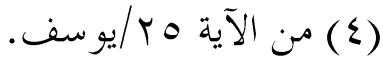

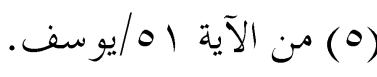

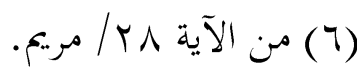

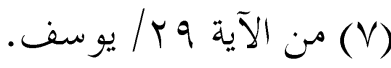




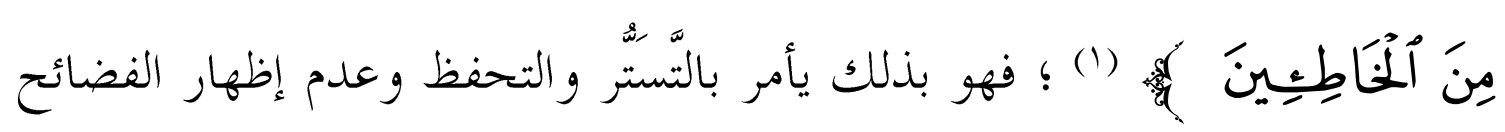

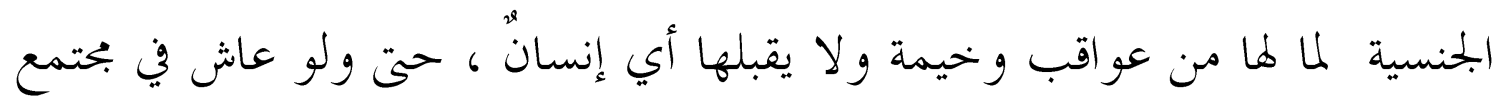
جاهلي. وبالنظر في السياق القرآني الذي وردت فيه هذه الكلمة دالة على الزنا - في

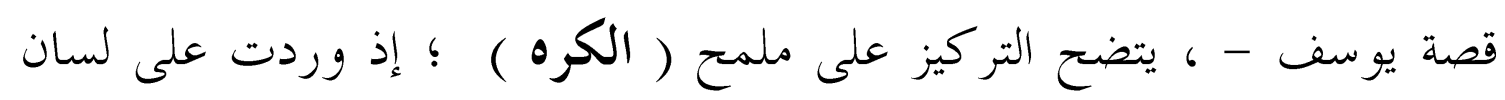

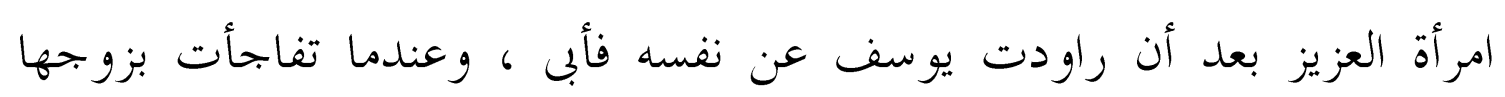

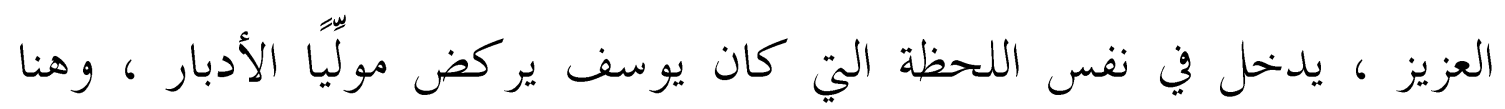

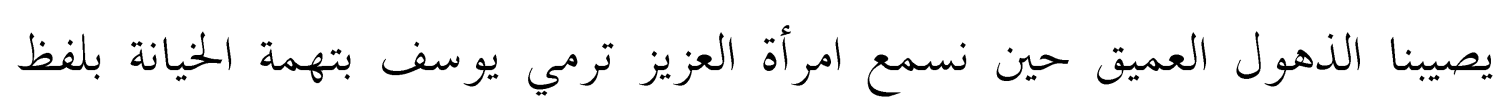

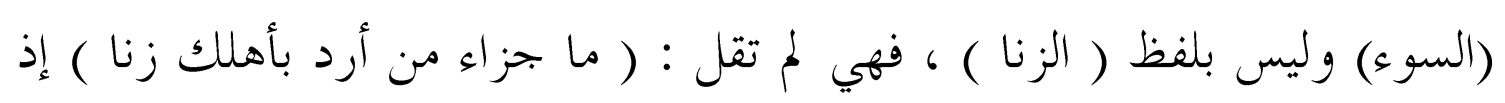

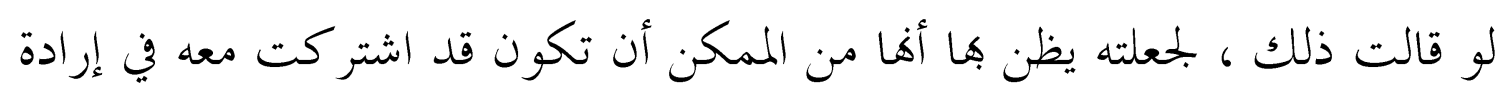

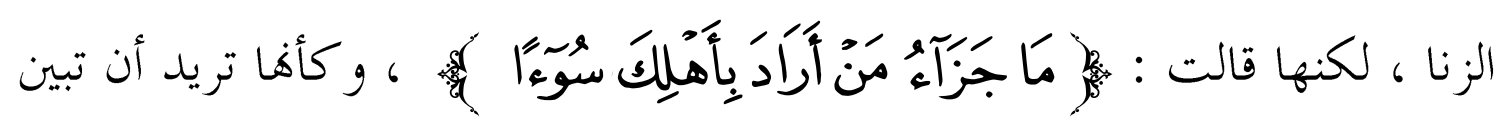

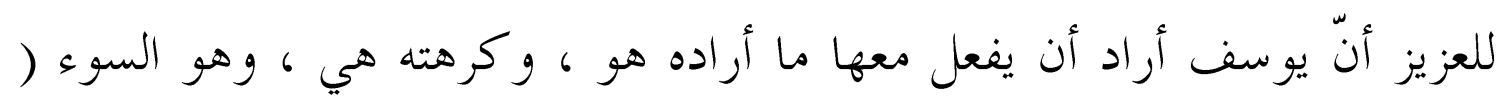

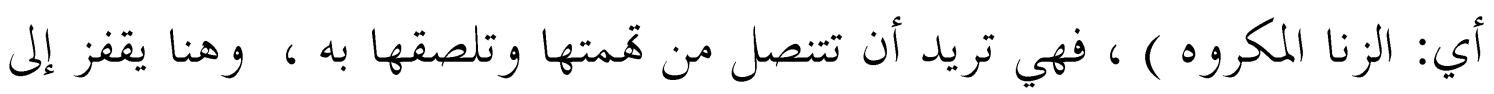

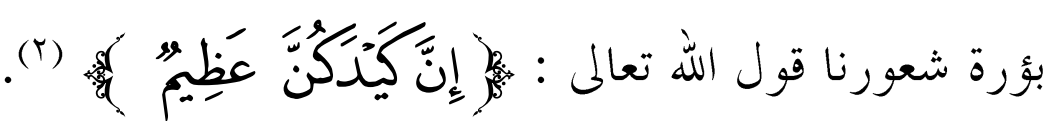

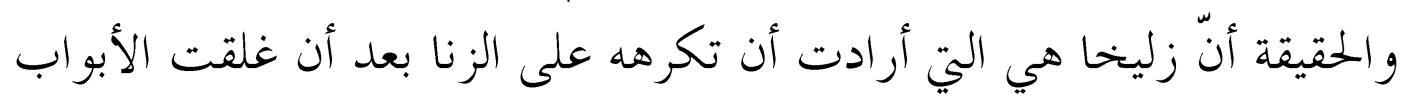

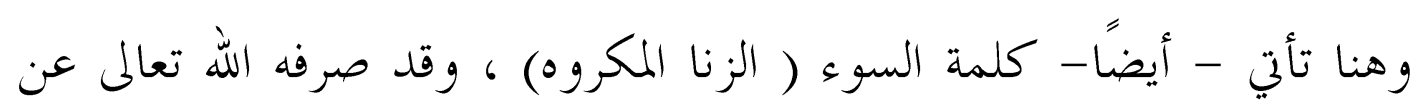

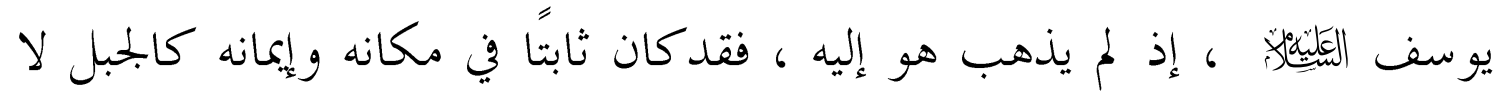

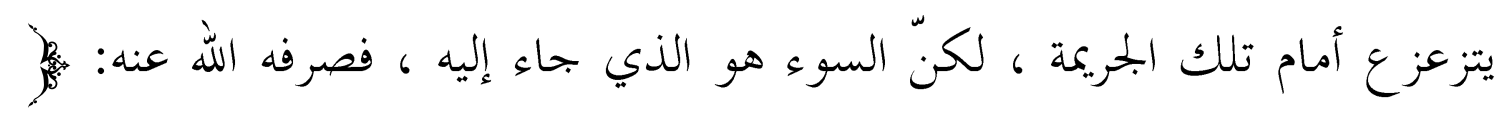




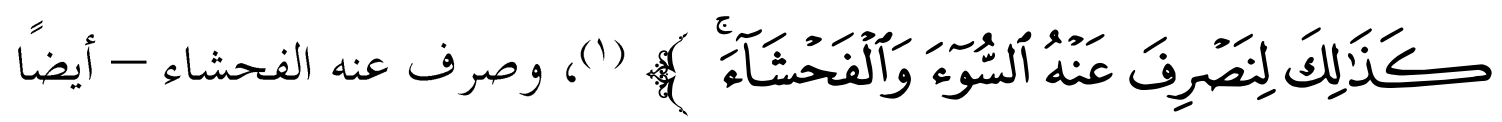

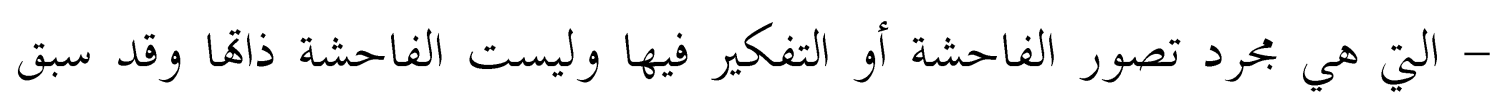
بيان ذلك.

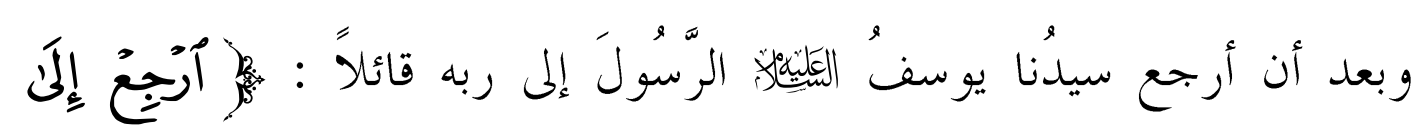

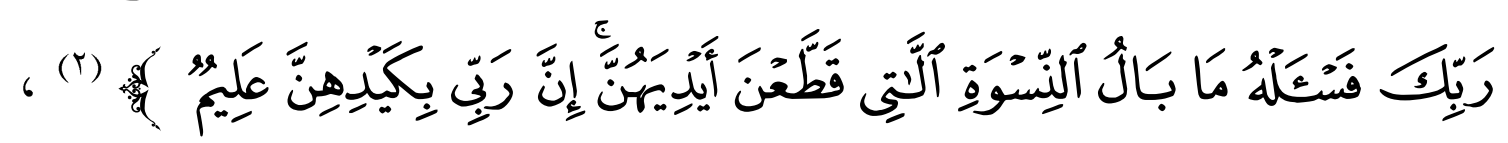

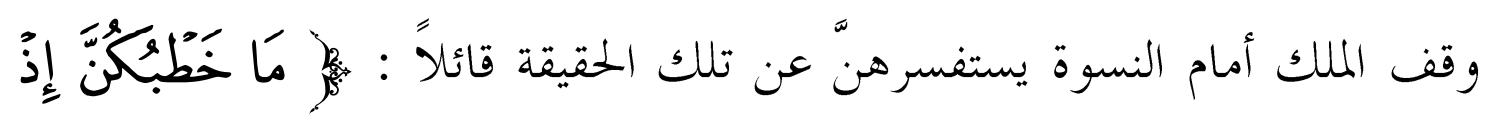

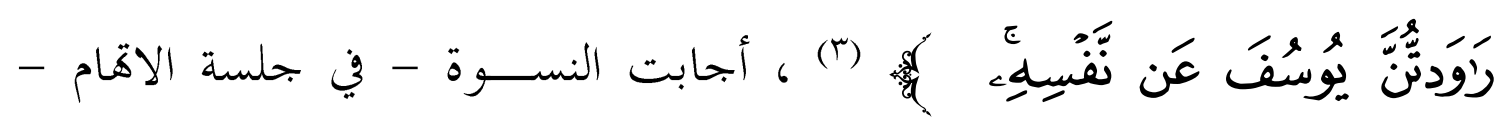

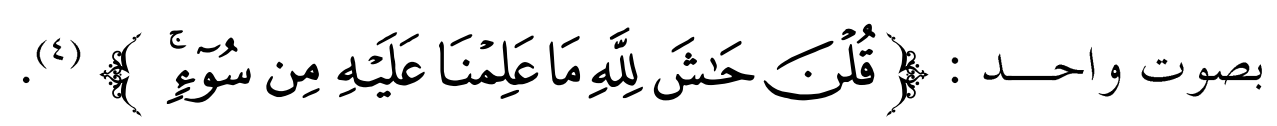

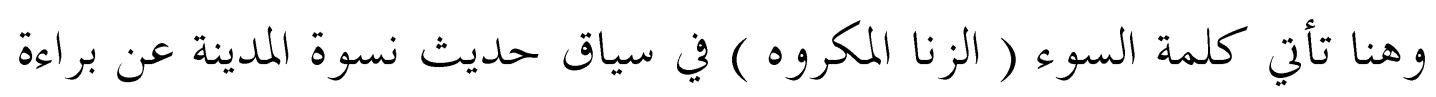

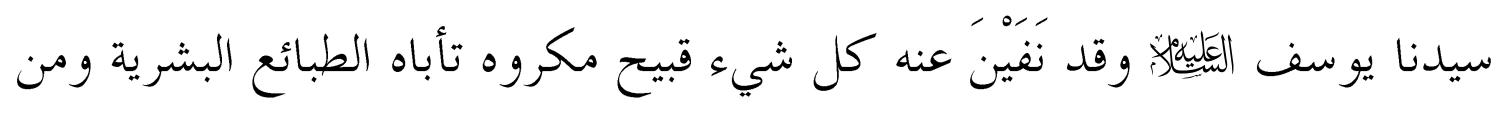

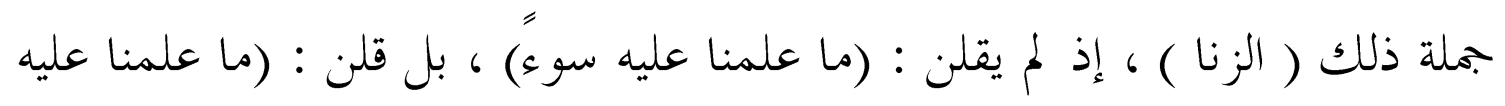

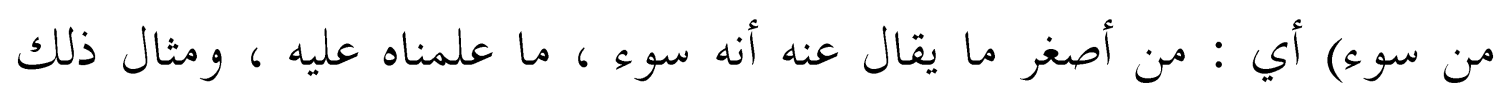

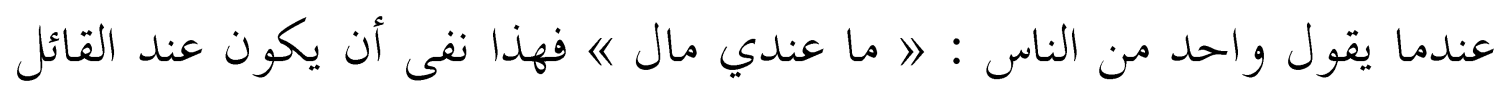

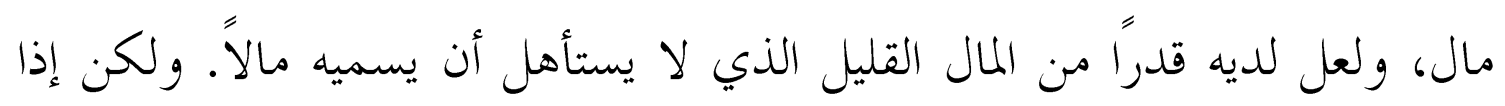

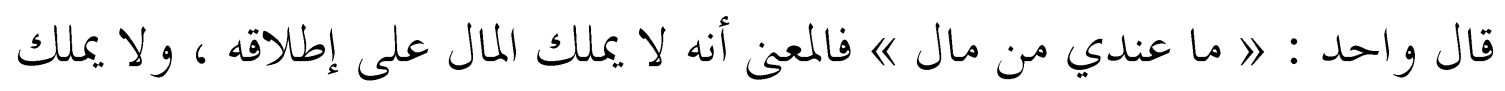

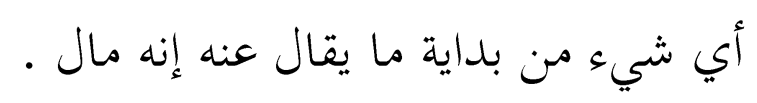

$$
\begin{aligned}
& \text { (1) من الآية ك ك/يوسف. }
\end{aligned}
$$

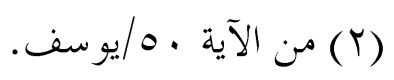

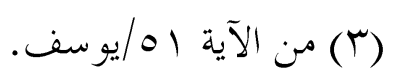

$$
\begin{aligned}
& \text { (乏) من الآية اله/يوسف. }
\end{aligned}
$$


وبعد اعتر اف هؤلاء النسوة ، تقدمت امرأة العزيز مطأطئةً رأسها بخجل وحياء،

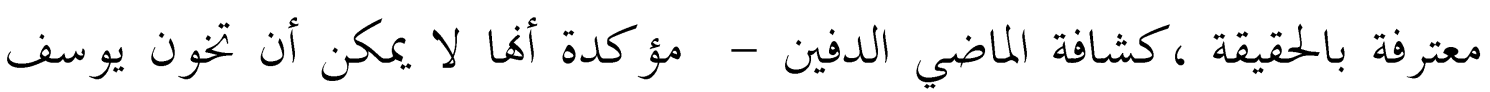
بالغيب - بأن تتهمه كما اتهمته من قبل -، أو أها لم تخن زوجها بالغيب - قائلة :

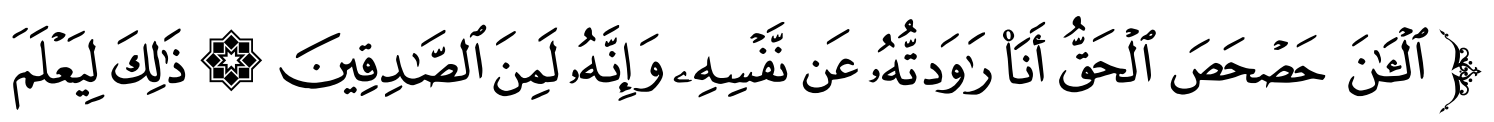

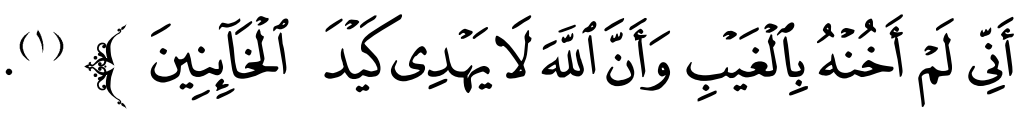

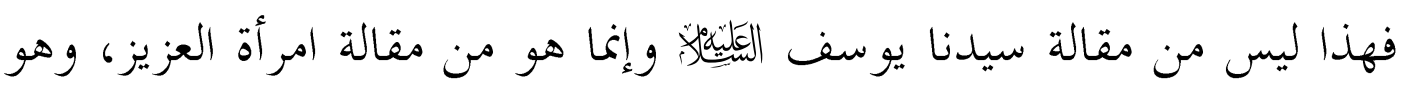

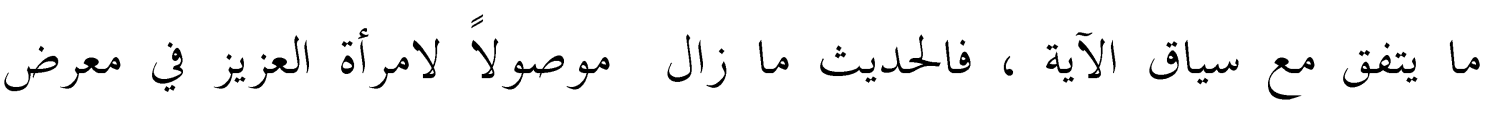

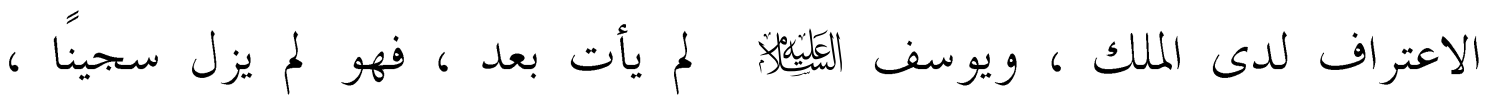

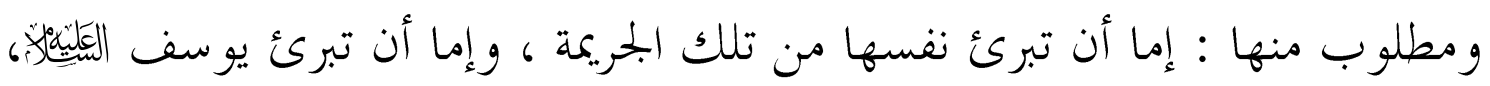

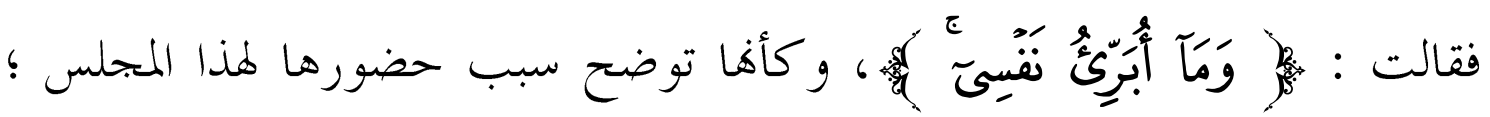
فهي لم تحضر لتبرىء نفسها.

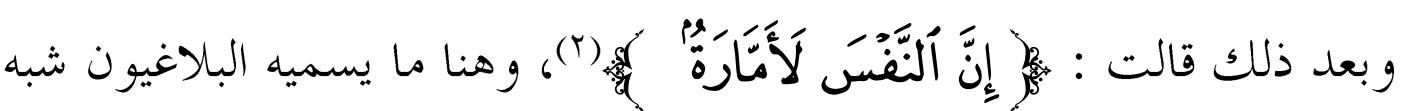
كمال الاتصال ، وهو: أن تكون الجملة الثانية جوابًا عن سؤال يفهم من الجملة

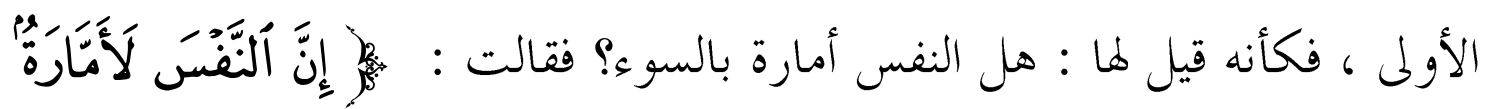

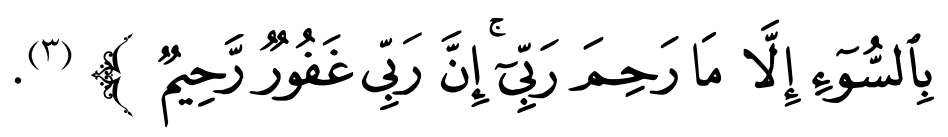

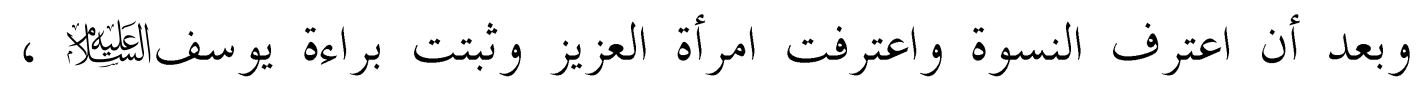
وعرف الملك الحقيقة كاملة، وتأكد مما ألحقه بيوسف من ظلم ، وما قاساه من 


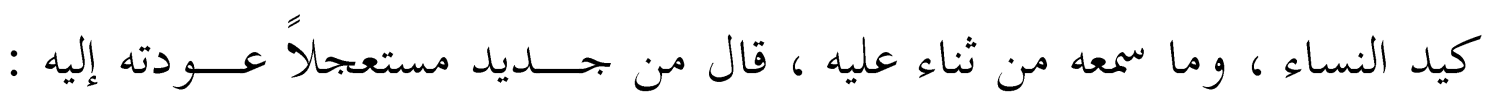

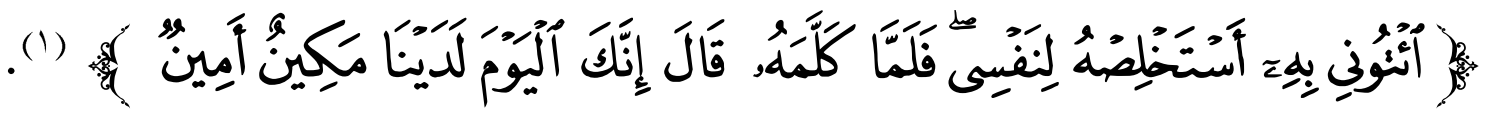

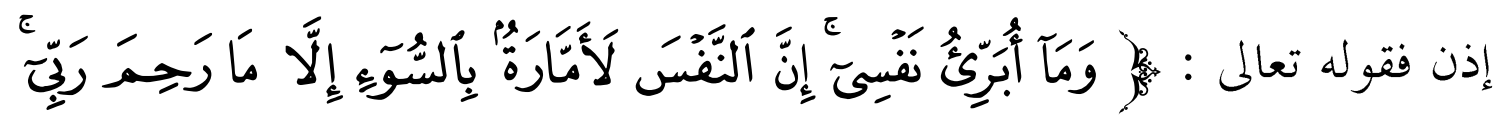

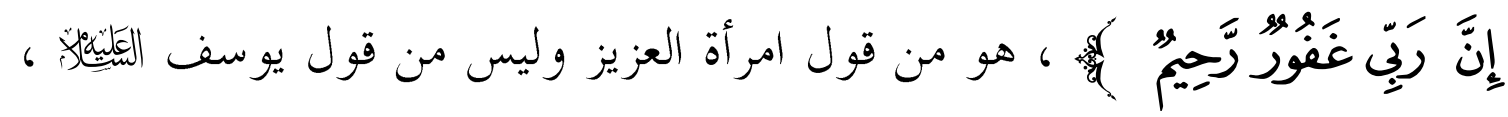
وهذا هو الأنسب بسياق القصة ومعاني الكام.

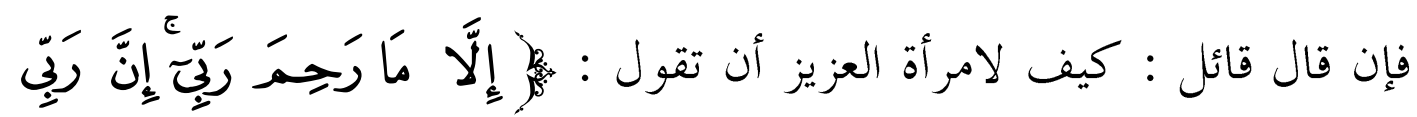

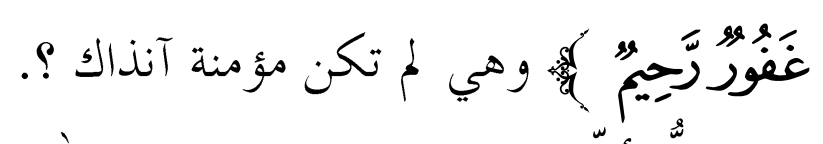

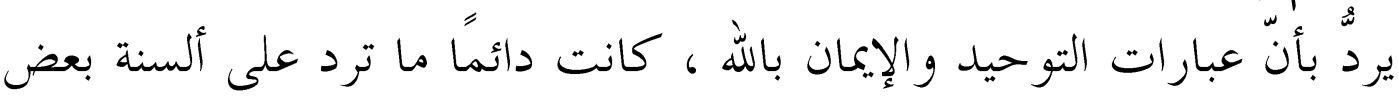
المسئولين في مصر ، وقد كان ذلك بتأثير سيدنا إبراهيم وذريته على المصريين ،

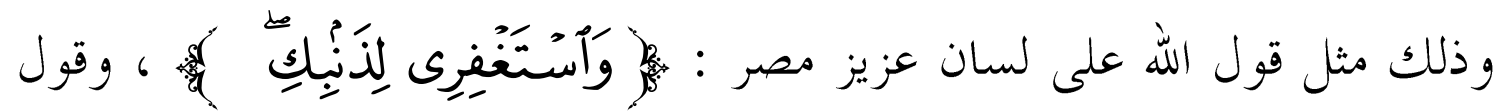

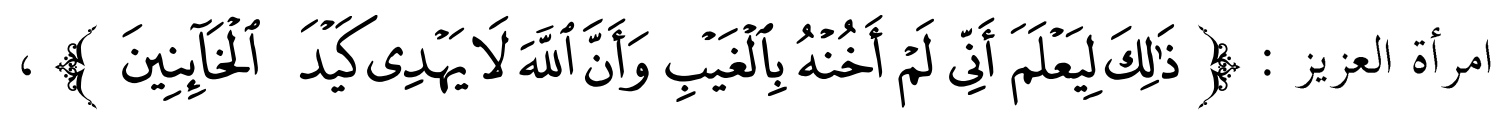

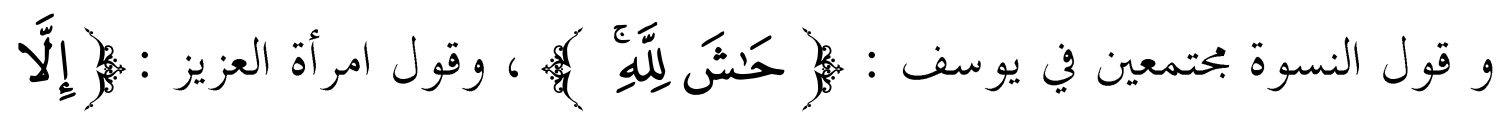

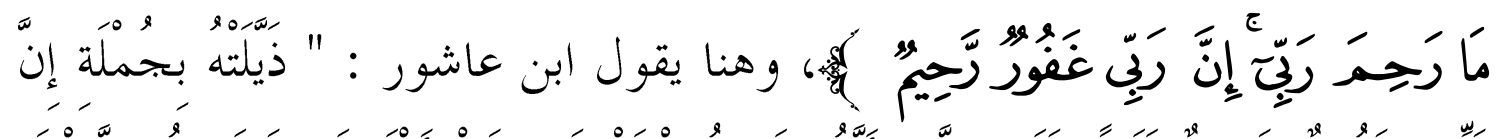

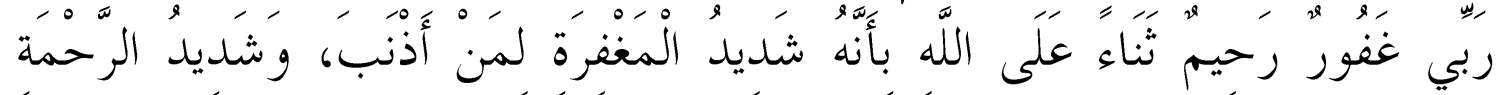

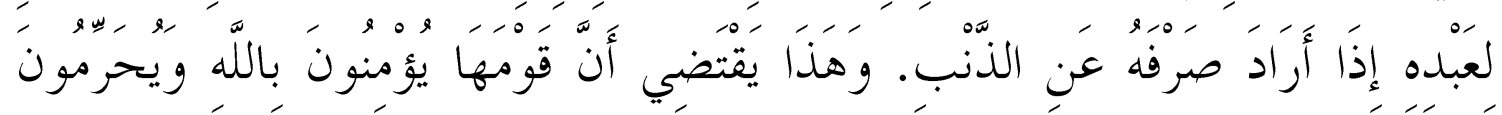

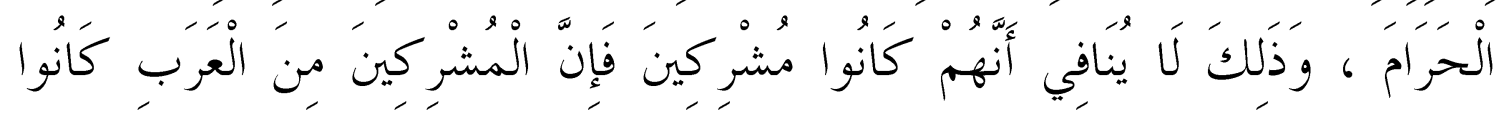




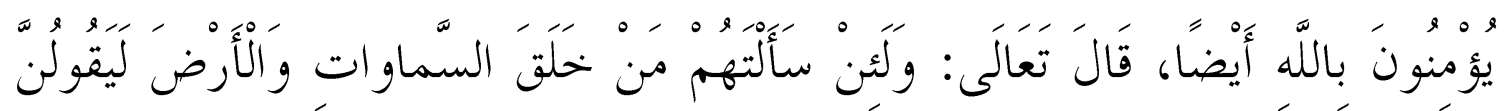

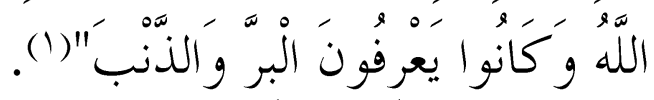

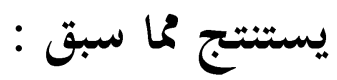

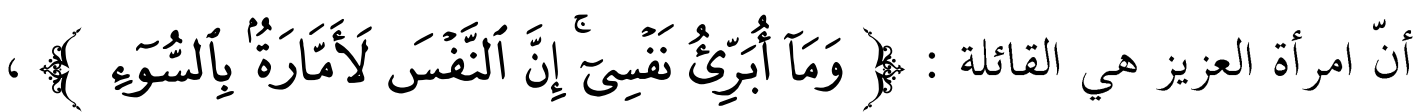

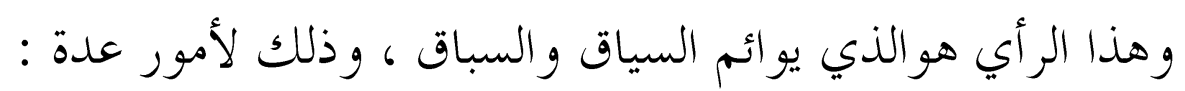

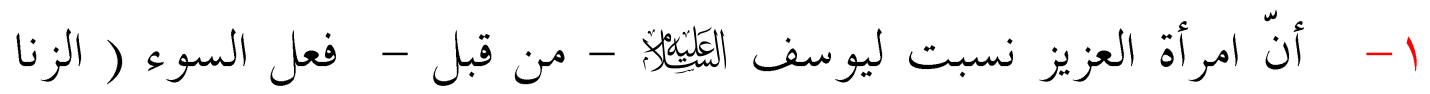

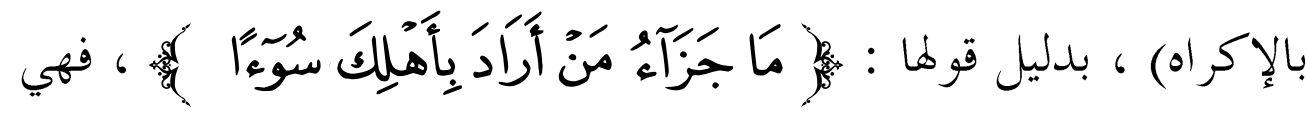

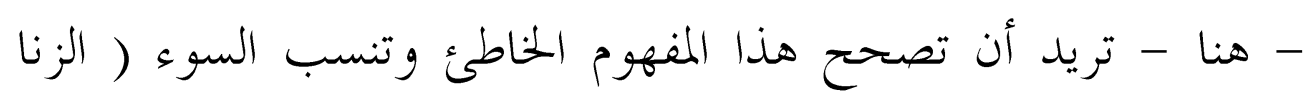

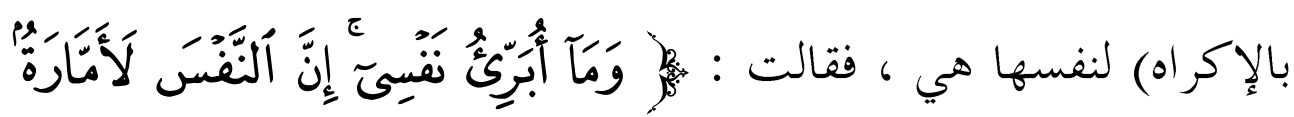

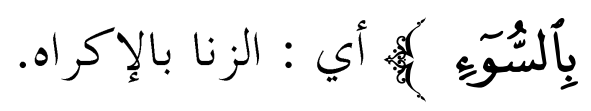

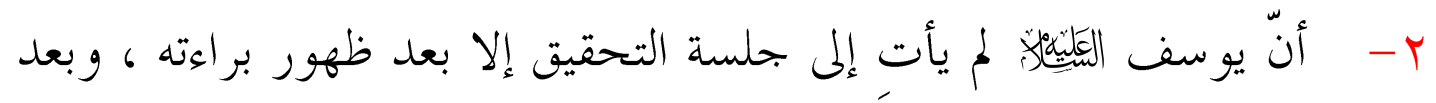

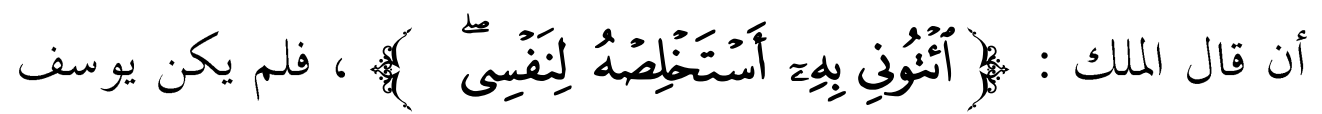

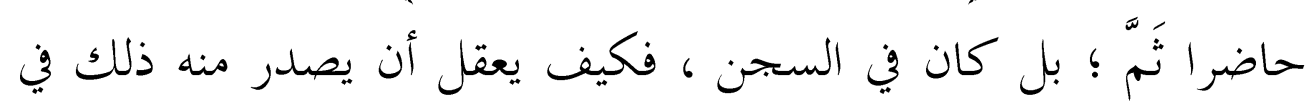

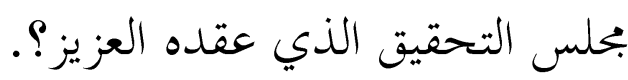

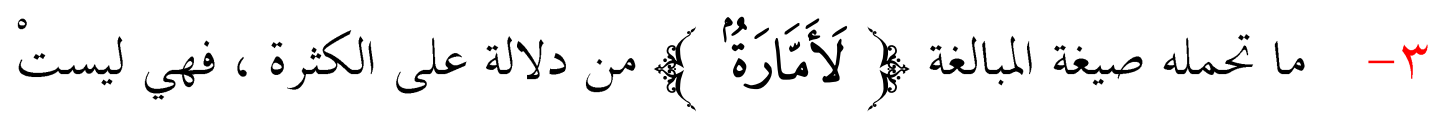

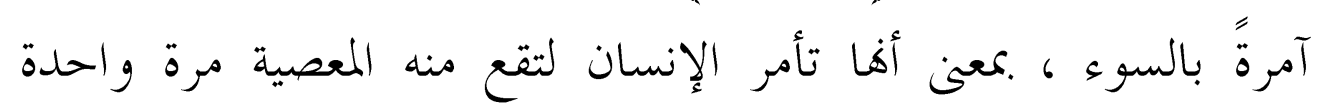

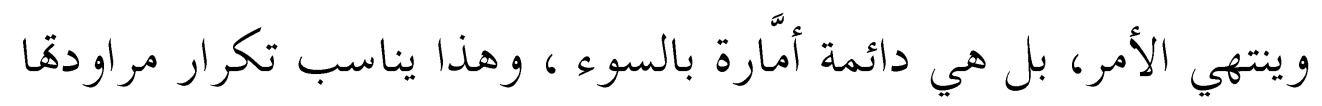




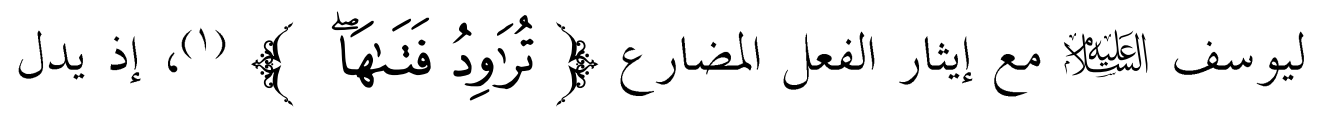

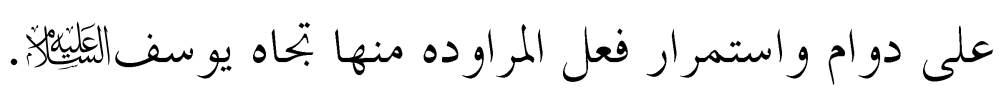
ع - بجيء كلمة (( النفس )) في سياق الآية مرتين ، إذ لم تقل: (وما أبرىئ نفسي إذا لأمارة بالسوء) ، بل قالت : (وما أبرىئ إنّ النفس لأمارة بالسوء) ، لئلا يتوهم تخصيص ذلك بنفسها فقط، و كأها تريد أن تشرك

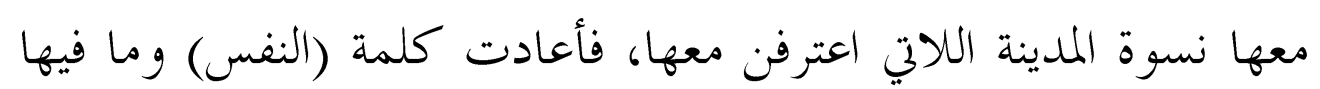

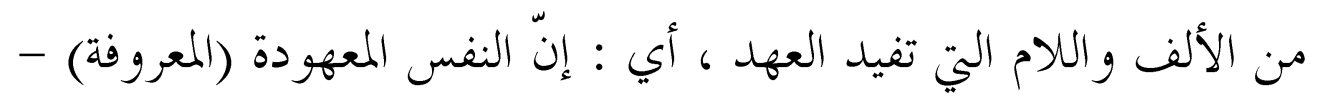

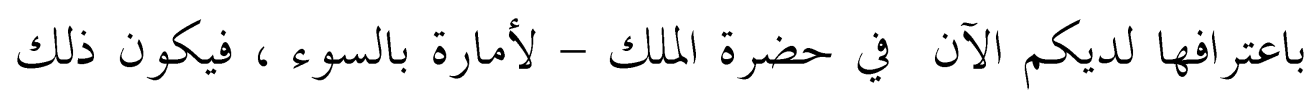

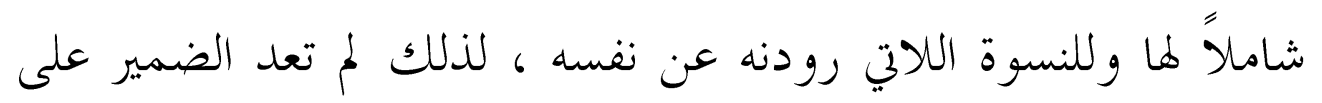
نفسها فتط. ه - بحيء أدوات التأكيد (إنّ - لأمارة) ، ومن المعلوم أنّ أدوات التأكيد لا لأل

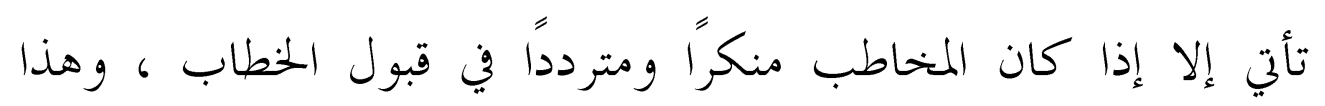
يوحي بأنّ الملك ومن حوله - في جلسة الاعتراف- كانوا منكرين

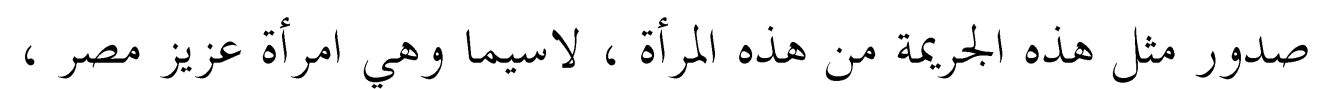
فأكدت لهم بقولها : (إنّ النفس لأمارة) لترجيح كفة الإثبات.

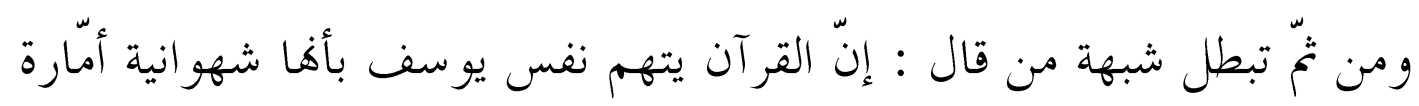

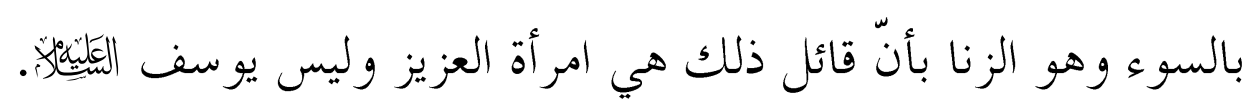

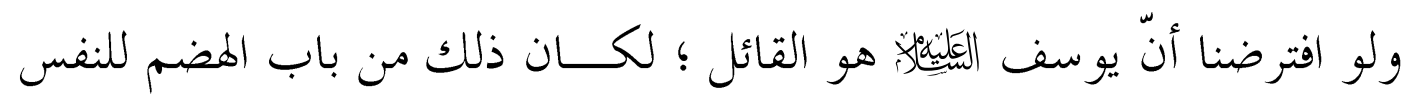

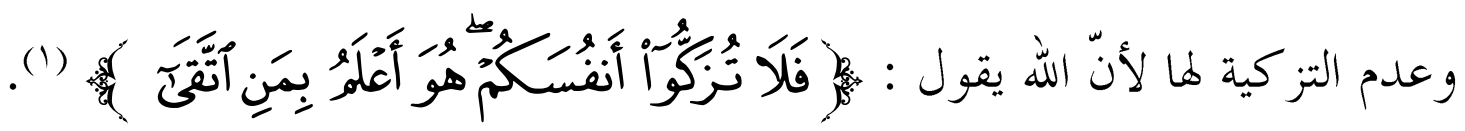


أما استدلال أعداء الإسلام .بما ذكره الطبري في تفسيره(r) من أنّ يوسف لما

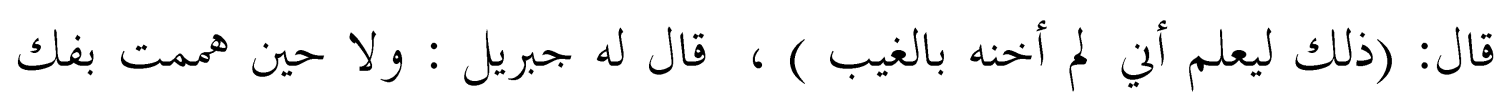
سر او يلك ؟ فعند ذلك قال يوسف : (وما أبرئ نفسي إنّ النفس لأمارة بالسوء).

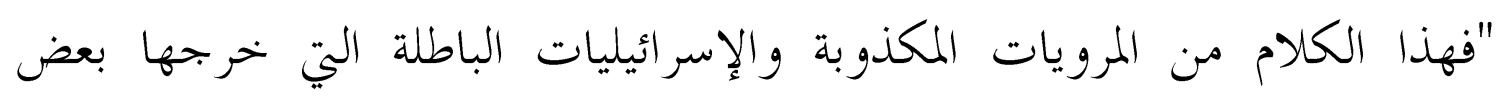

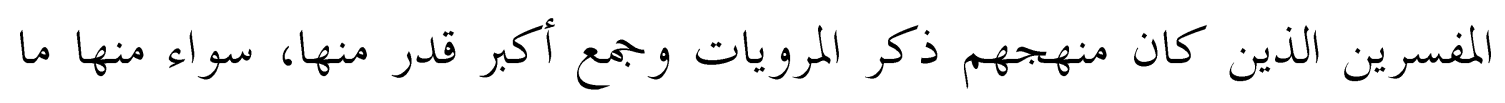

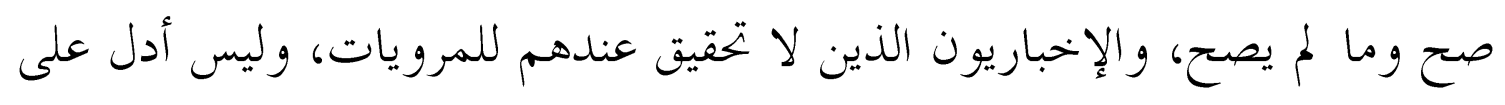

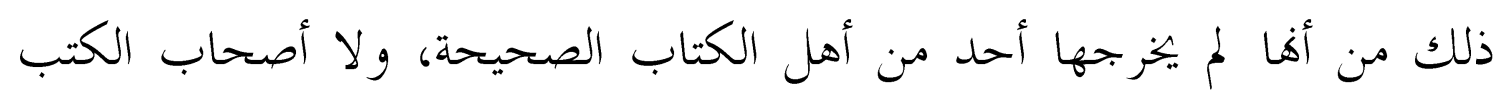

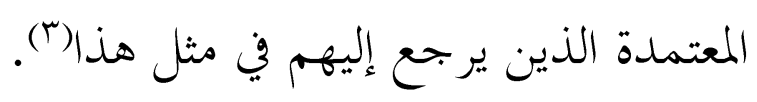

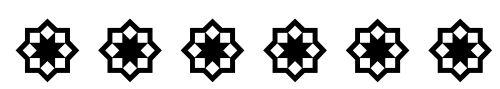

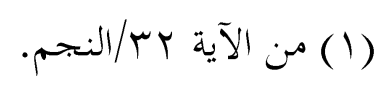

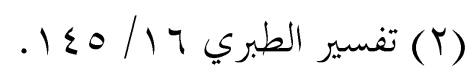

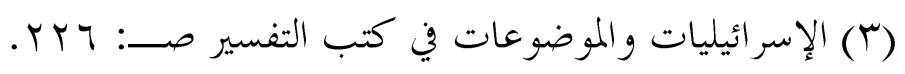




\section{المبحث السادسر : في دلالة لفظة : ( الزنا ) :}

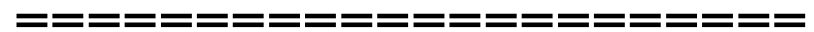

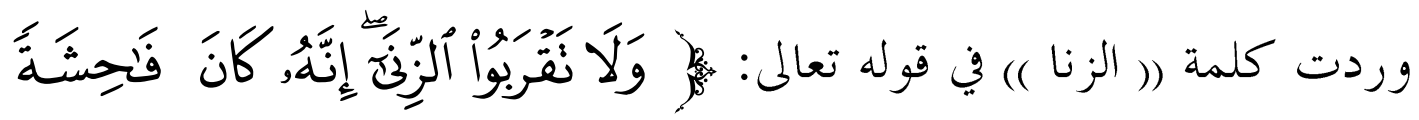

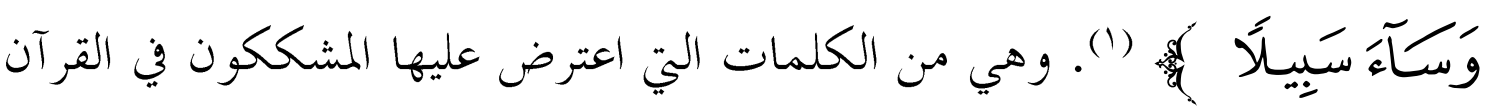

وقالو ا: أنى لمثل هذه الكلمة أن ترد في كتابكم، فهي كلمة خادشة لثوب الحياء؟ .

و هؤلاء لم يفهموا الدلالة اللغوية للكلمة، وما ذلك إلا لجهلهم باللغة العربية

و اشتقاق ألفاظها ، إذ أنّ كلمة ((زنا )) من الناحية الاشتقاقية قد تبين أنها مأخوذة

من (( الزناء )) وأصل الزناء : الضيق ، وزنا الموضع يزنو : ضاق لغة في يزنأُ (؟).

و بالرجوع إلى الدلالة الأصلية للفظ (( الزنا )) تبين أها تطلق على معنيين :

الأول: الضيق 6 و منه قيل للحاقن (( زناء )) 6 لأنه يضيق ببوله ، و منه أيضًا

يقال : زنأ في الجبل يزنأ إذا صعد لأنه يضيق بذلك نفسه ، ووي الحلديث : (رأنه

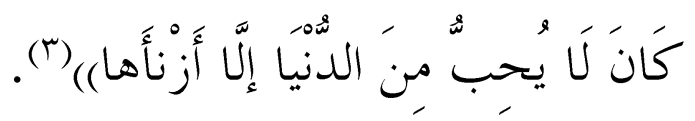

الثاين: الزنا .كعنى : وطء المرأة من غير عقد زواج .

وبالربط بين المعنيين من الناحية الدلالية تبين أنّ كلمة (زنا) تحمل ملمحًا دلاليًا ميزًا و هو (( الضيق )) ، و وكأن الزاني و الزانية يصبان بالضيق النفسي من أثر

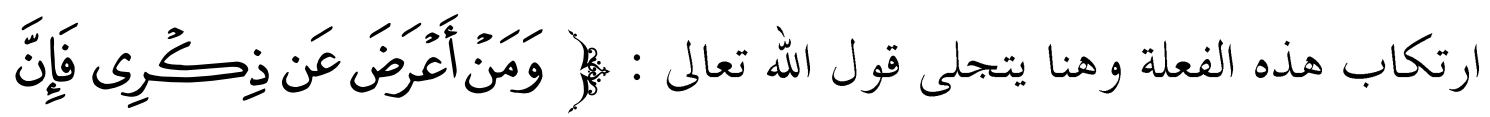

$$
\begin{aligned}
& \text { (1) من الآية بr/الإسراء }
\end{aligned}
$$

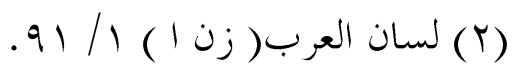

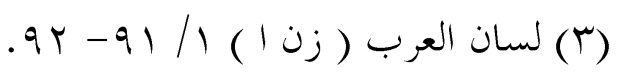




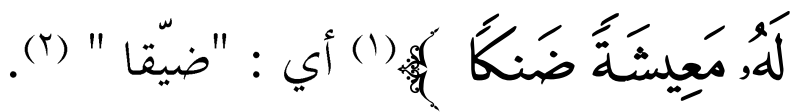

وهذا الملحظ الدلالى للفظة (( الزنا )) - بدلالته على الضيق - يؤكده علم

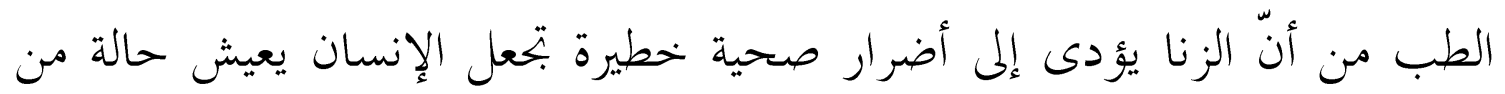

الضيق و القلق، إذ مددد البشرية بالأمراض الخبيثة ، التي يصعب علاجها ـ من تلك:

- السيلان : وهو من الأمراض التي حار في علاجها الأطباء ، وهو ترك

المصاب في حالة من الألم .. وسببه ميكروب السمه (( جونوكوك ) ) ..

وهو ميكروب كلوى الشكل ، يتراص في أزواج .. وينتقل ذلك

الوباء بالاتصال الجنسي ، أو استعمال الأدوات الخاصة بالمصاب به ، 6

وينتقل المرض عادة من الأنثى المصابة إلى الذكر أثناء المعاشرة ،

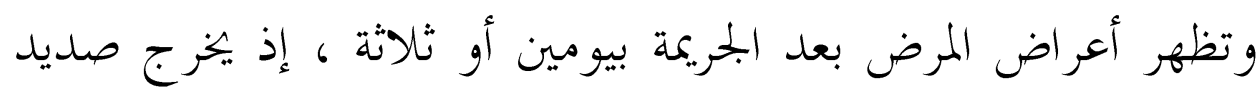

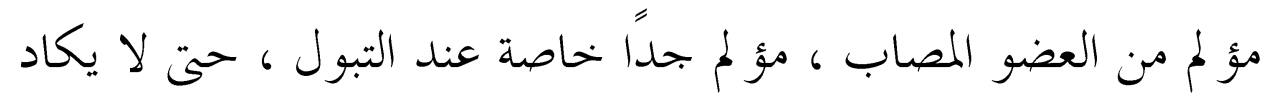

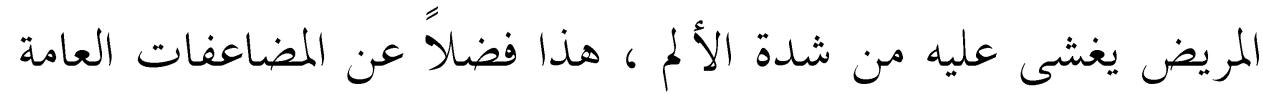
من التهابات المفاصل ، و التهاب قزحية العين. أما بالنسبة للإناث فمرض السيلان يؤدى إلى التهاب غدة بارثولين ، و التهابات عنق الرحم ، وقنوات فالوب ، فضلاً عن الآلام الشديدة

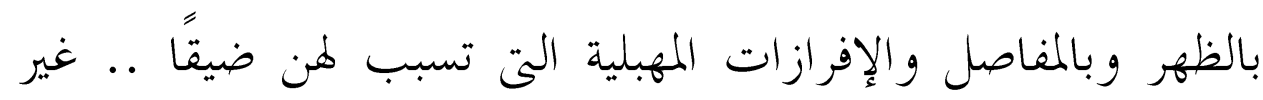

$$
\text { الإصابة بالعقم في كثير من الأحيان. }
$$

- السفلس أو الزهرى : وهذا المرض تتجلى فيه عقوبة الله تعالى ، فالمريض بعد أيام أو أسابيع من جريمته ، يصاب ببثرة غير مؤلمة مكان

$$
\begin{aligned}
& \text { (1) من الآية ع با /طه. }
\end{aligned}
$$

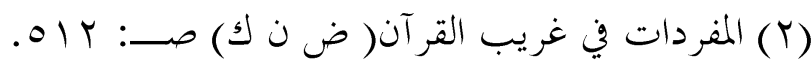


الجريمة ، وتزول هذه البثرة بعد أيام قلائل لتحل الجرثومة في الدم ، وبعد سنة أو سنتين تخرج عليه بقع حمر اء نحاسية تنتشر في بعض أنحاء جسمه ... و يغفل المريض عن مراجعة الطبيب ليستمر المرض وتستمر الجرثومة في دم المريض تعيش فيه وتظهر في قلبه أو في كبده وأحشائه.. الغريب أن تلك الجرثومة تلحقه إلى عقبه ، فالجنين يموت

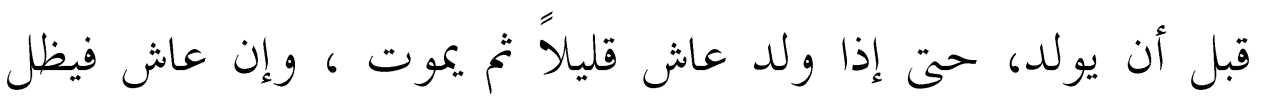

$$
\text { مريضًا" (') مئر }
$$

هذا ، ويسبب الزنا غير ذلك ما يسمى بالقرحة الرخوة أو اللينة ، وهى مؤلمة جداً يكثر ظهورها في جسم القضيب أو الصفن أو العانة.. أما في الإناث فيكثر و جودها في الشفرتين وقرب فتحة الشرج و الفخذين ، وهى قابلة للتعدد. ما يسمى

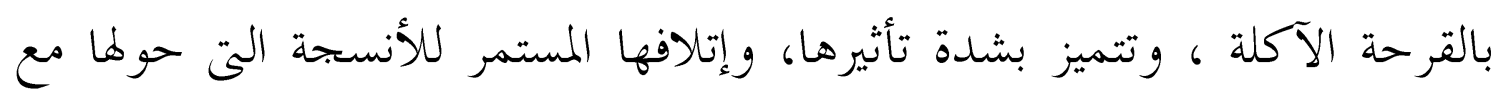

$$
\text { عدم رضوخها للعلاج }
$$

أنّ كلمة (( زنا )) في أصل وضعها تدل على الضيق عامة ، ثم خُصِّص معناها وأصبحت مصطلحاً دينيا يصف العلاقة الجنسية المحرمة بين الرجل و المرأة (أي التي خارج نطاق الزواج الشرعي ) وذلك لما في الزنا من الضيق النفسى الناتج عن الأمراض العضوية ، لذلك يعتبر الزنا من الكبائر ومن أعظم الخطايا التى هى الله عنها .

(1) الفاحشة والأمر اض : د. وجيه زين العابدين (بحث منشور بمجلة الوعى الإسلامى عدد أغسطس

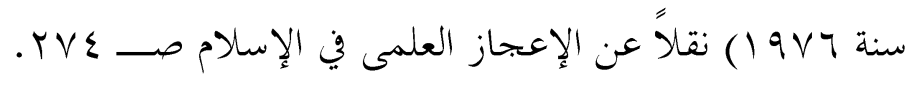

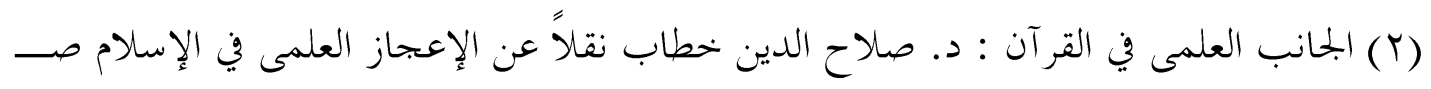


وقد وردت كلمة ((زنا)) في القرآن الكريم تسع مرات في سياقات كلها تدل

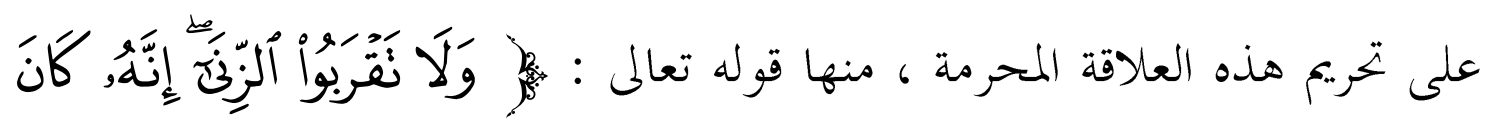

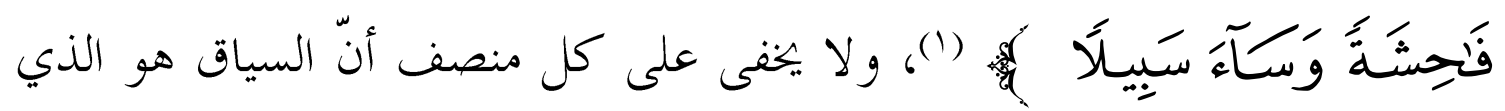
يهكم على الكلمة من حيث قبحها وحسنها. والحق أنّ هؤلاء المشككين الذين اعترضوا على ورود كلمة (زنا) يناقضون

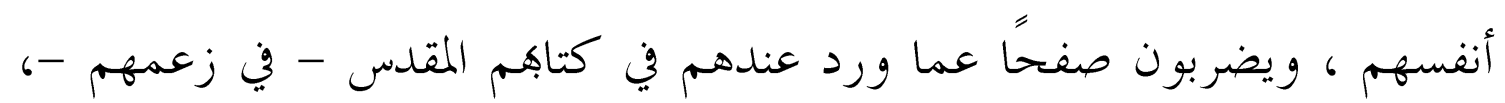
فقد وردت عندهم هذه الكلمة نفسها في سياق يثير الغرائز مما يتنافى مع الأدب

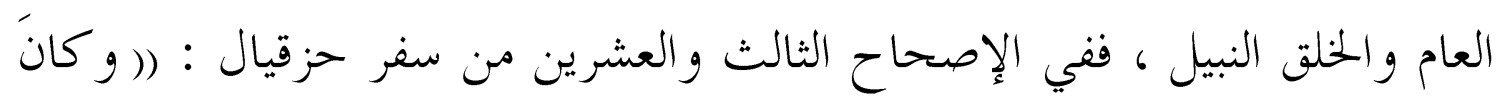

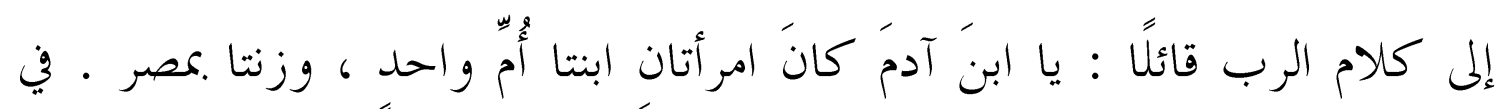

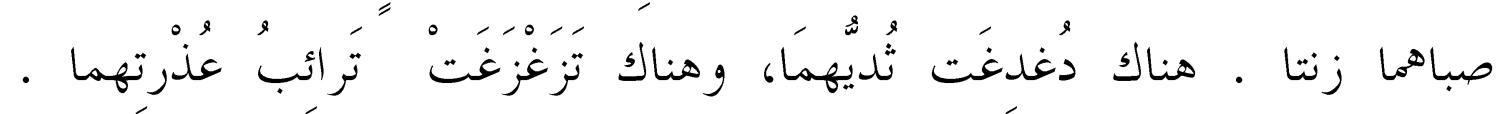

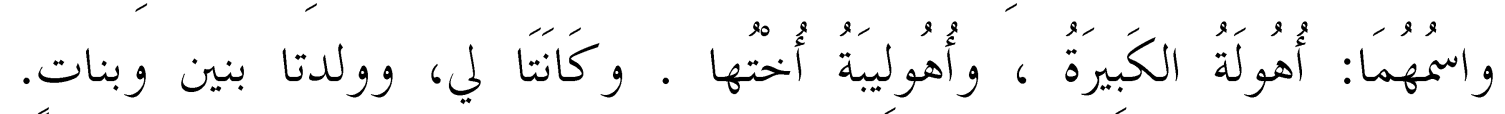

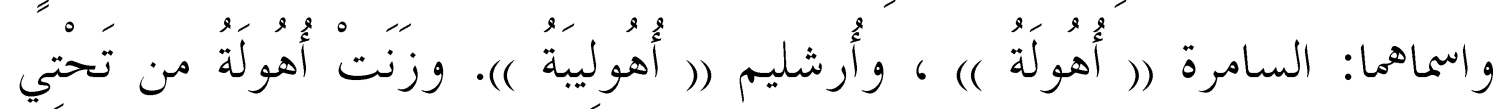

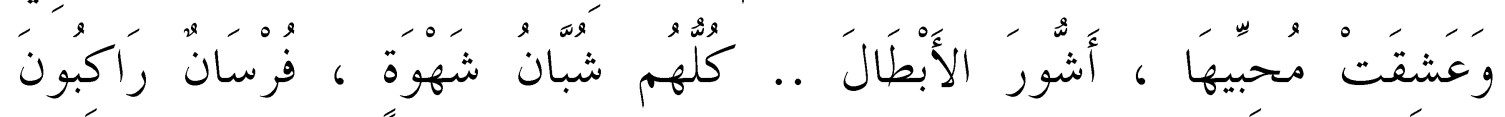

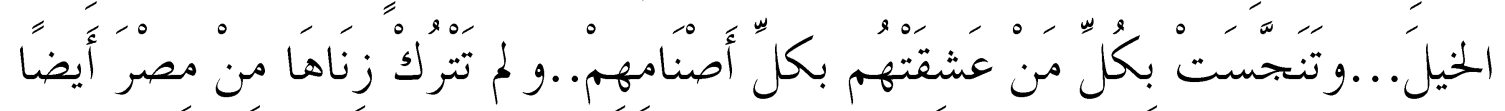

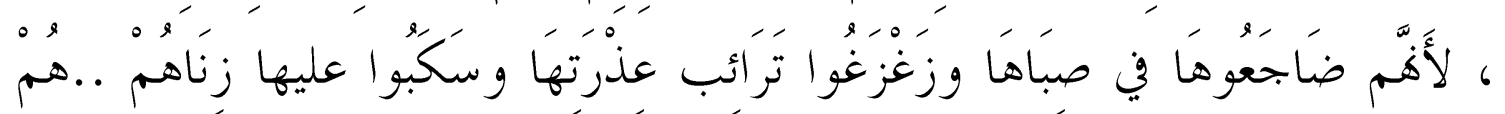

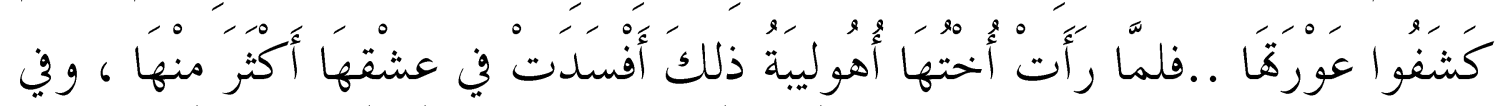

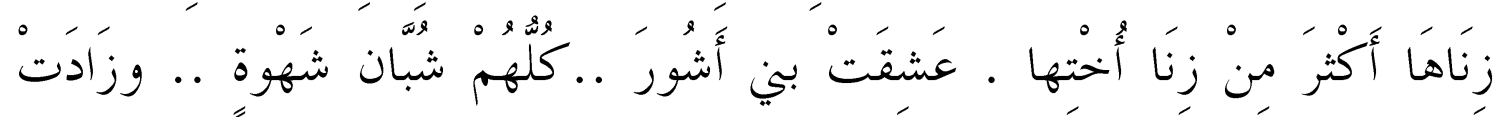

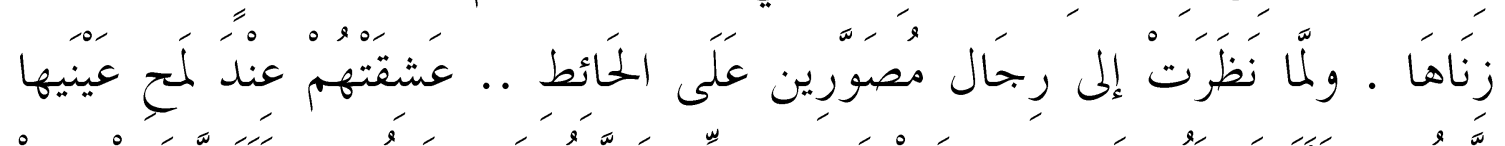

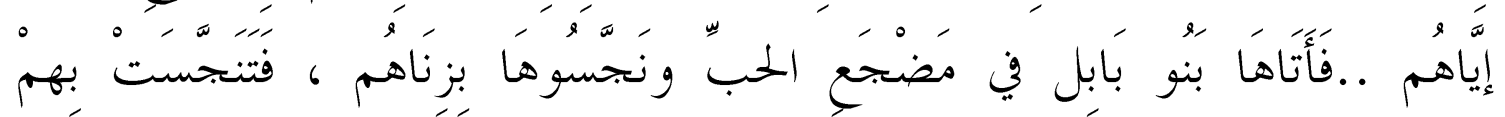

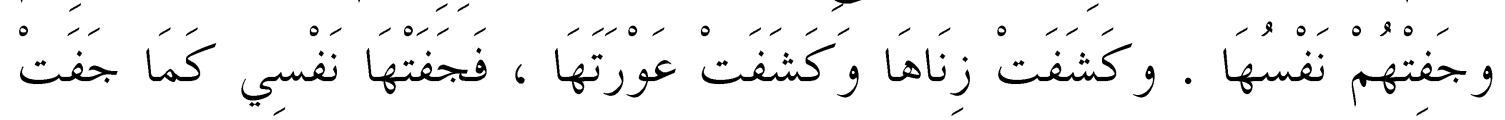


الدلالة اللغوية بين رقي القرآن وشبهات المستشرقين وجهلهم بإعجاز اللفظ القرآني.

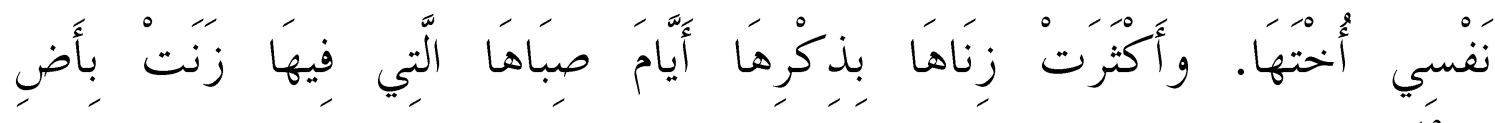

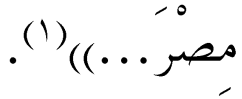

وهنا بند صرخة الحياء مدوية منما في هذا السياق من دلالة على الفضائح

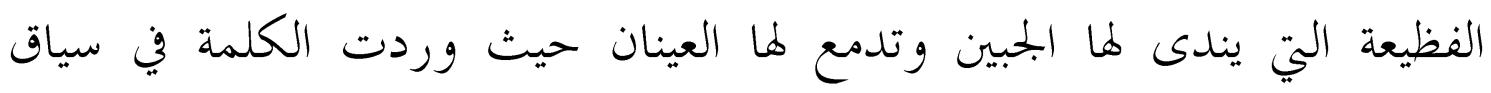

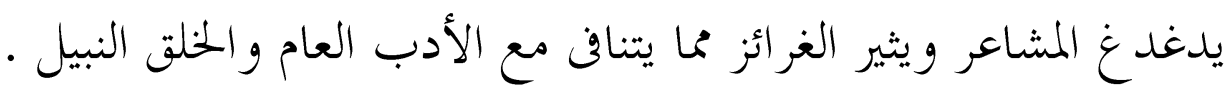

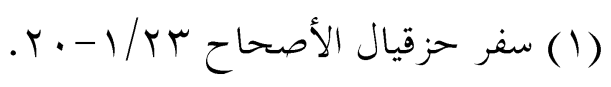




\section{المبـهث السابـر : في دلالة لفظة : (البغاء) :}

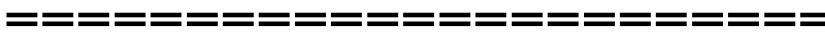

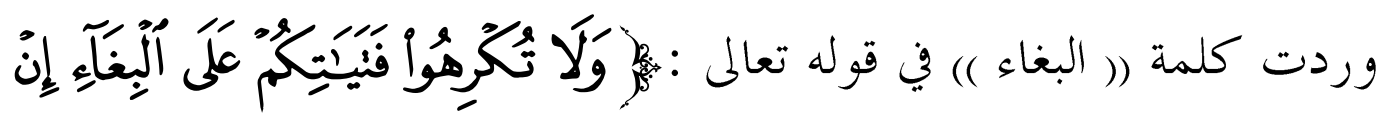

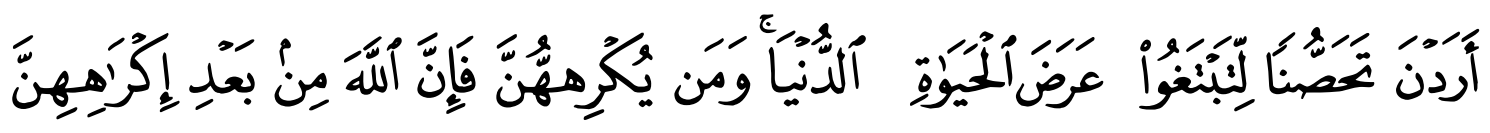

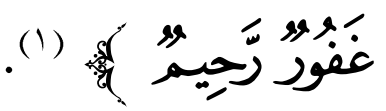

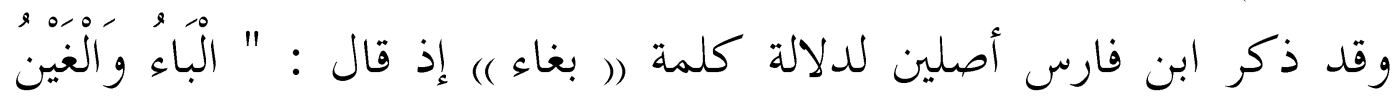

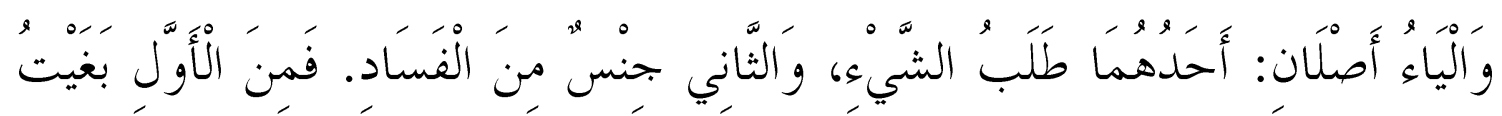

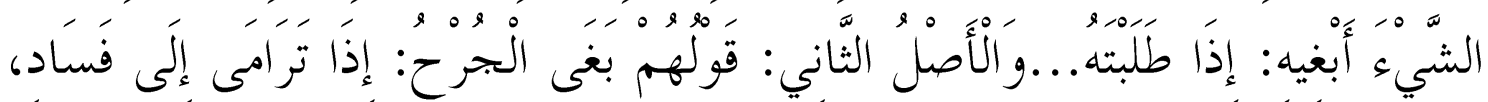

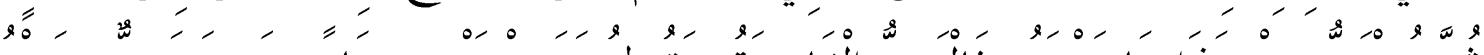

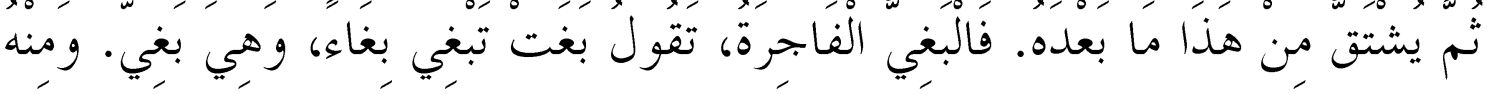

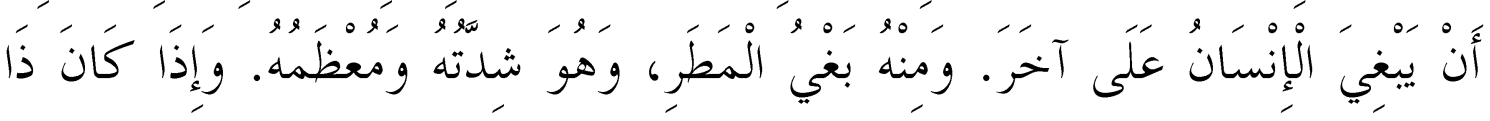

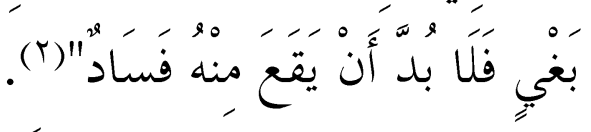

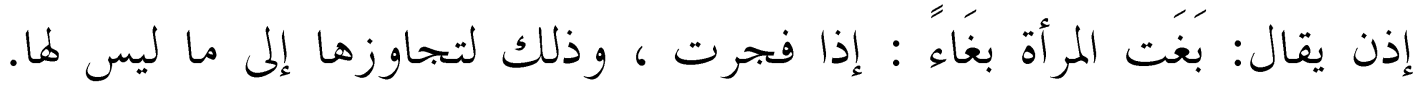
ويقال: باغت الجحارية إذا تعاطت الزنا بالأجر حرفة لما، فالبغاء الزنا بأجره. ويتميز لفظ (( البغاء )) في دلالته على الزن بملامح عدة هي :

$$
\text { (1) من الآية كس/النور. }
$$


- - تبحاوز الحد في الزنا لدرجة المجاهرة ، إذ اللفظ مأخوذ من"بغت المرأة

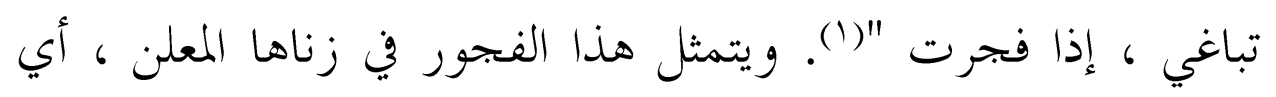

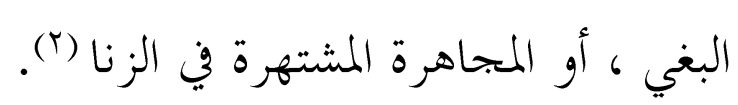

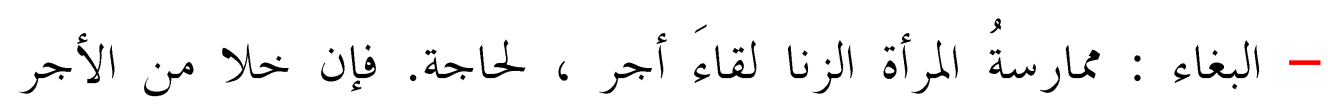

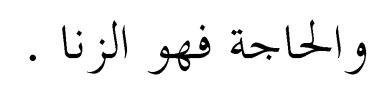

- البغاء غختص بزنى النساء فلا يقال للرجل إذها .

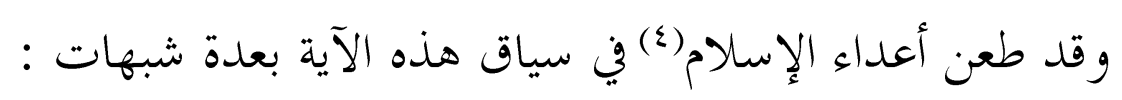

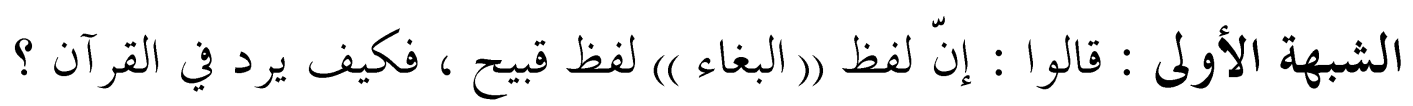

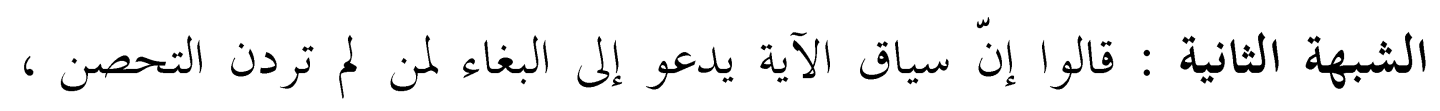

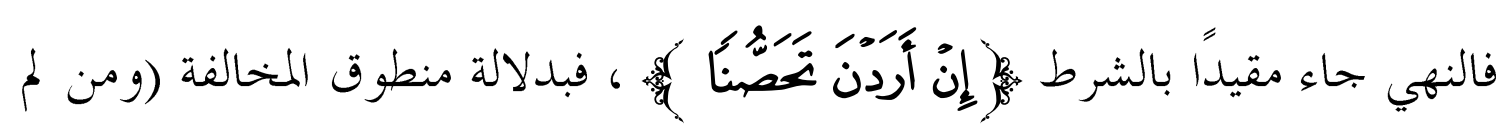
تردن التحصن فلها أن تبغي) .

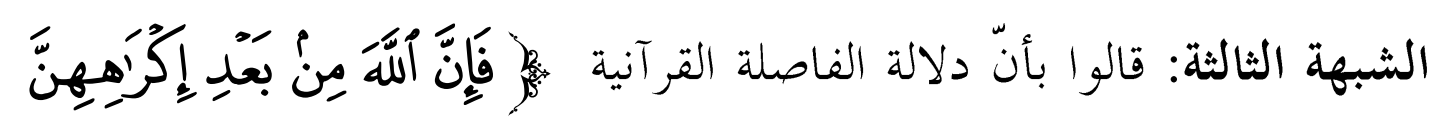

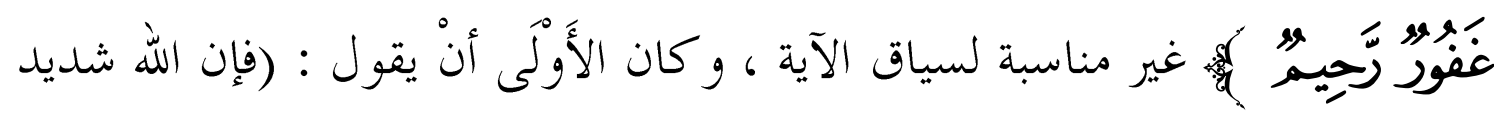
العقاب) بإسلوب العقاب والتهديد.

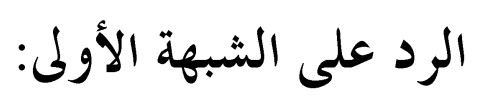

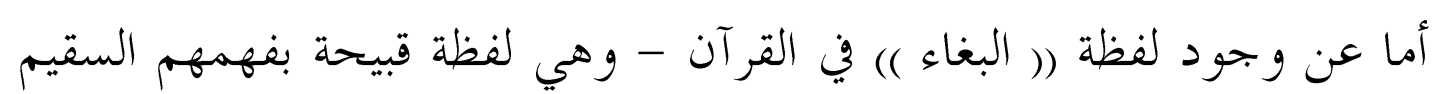

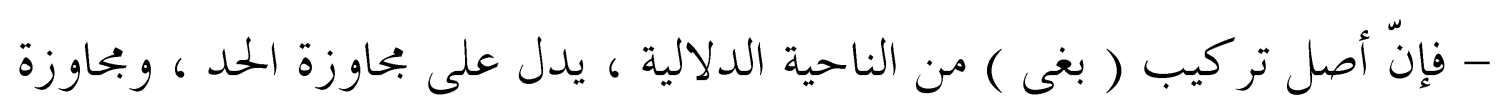

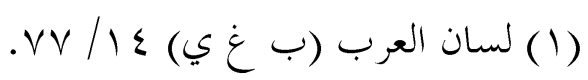

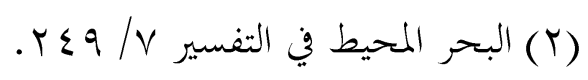

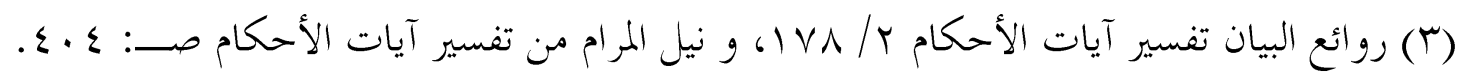
(ع) ومن هؤلاء القسيس عبدالله الفادي في كتابه (لا عصمة للقرآنان). 
الحد منه ما هو محمود ، كتجاوز العدل إلى الإحسان. ومن البغي المحمود قوله

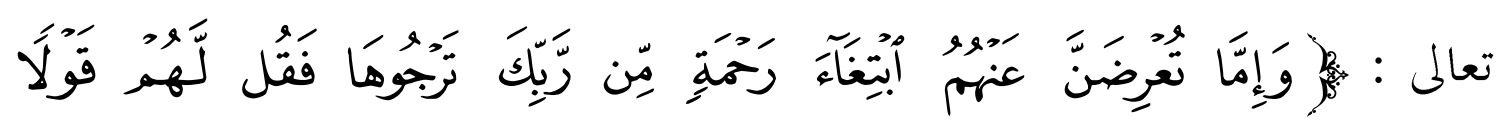

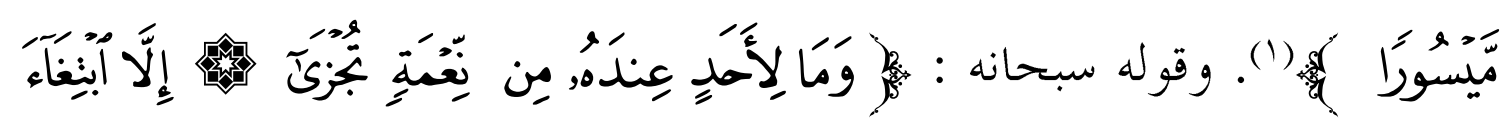

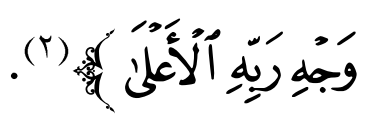

ومنه ما هو مذموم،وهو تبحاوز الحق إلى الباطل، ومنه البغاء.معنى (( الزنا ))(").".

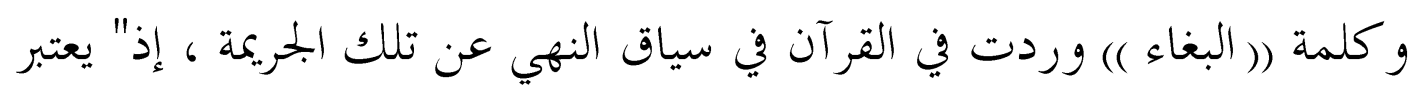

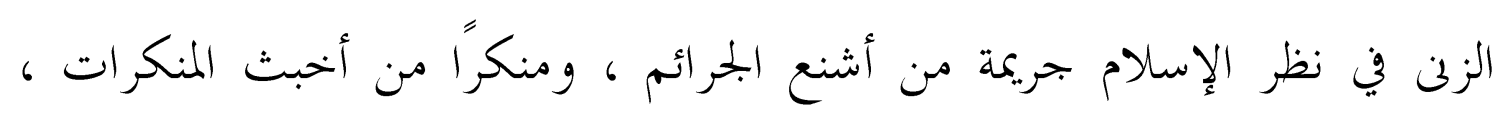

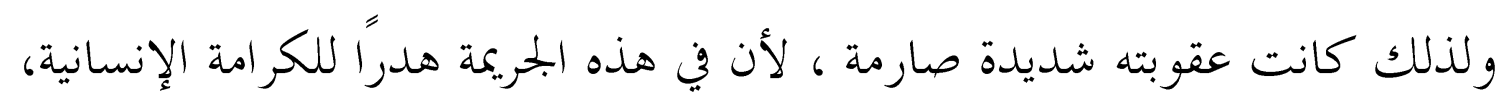

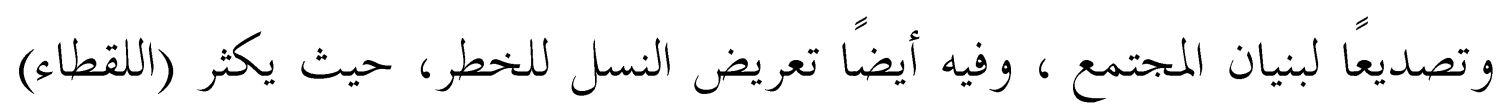

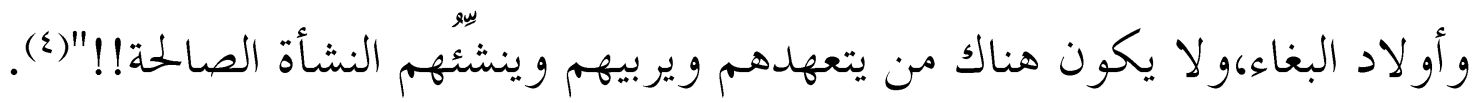

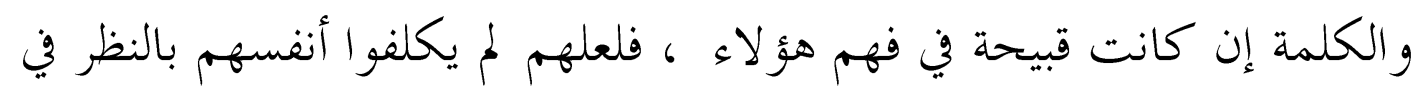

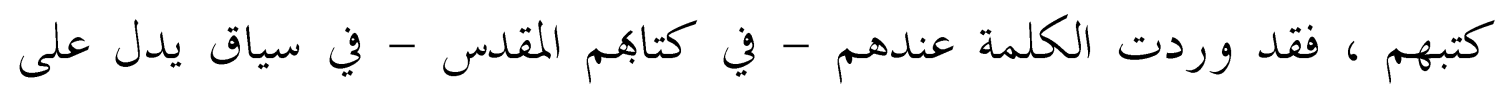

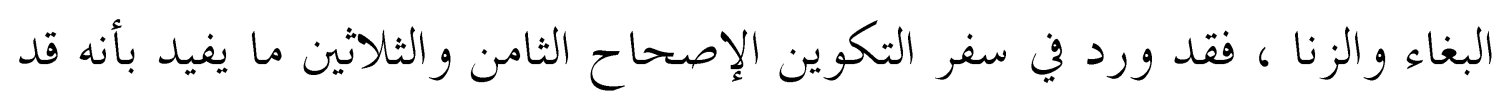

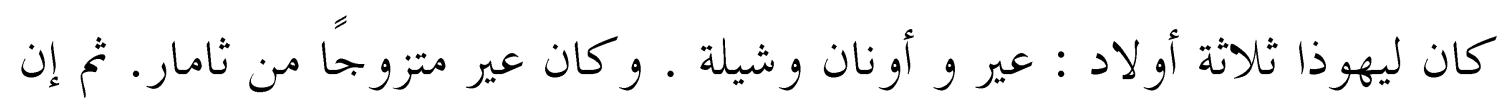

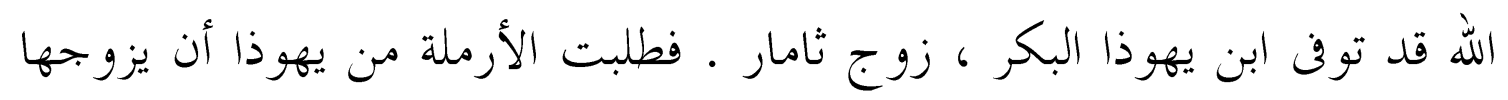

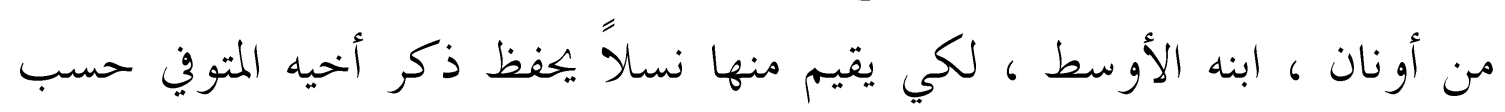

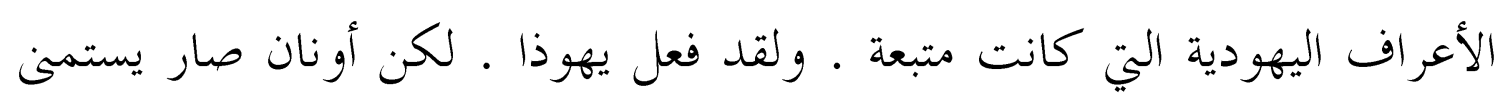

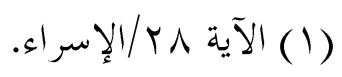

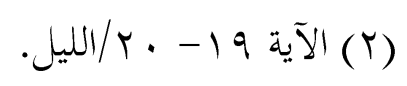

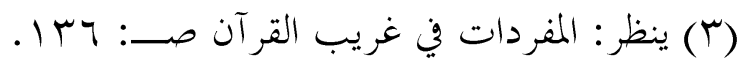

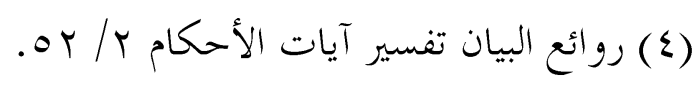


على الأرض ؛ لكي لا يقيم لأخيه نسالًا . فأماته الربٌّ جزاء ما فعل. وعندما

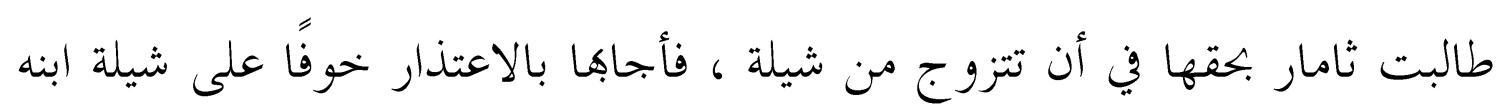
الأصغر من أن يموت كما مات أخوه. وطلب منها أن تقر في بيت أبيها حتى يكبر شيلة . غير إن هذا الانتظار قد طال أمده ـ و وفي أحد الأيام علمت ثامار أن يهوذا سيذهب إلى جز” غنمه ، (( فخلعت ثياب إرمالها من عليها وتغطت بالخمار واحتجبت به وجلست في مدخل العينين على طريق تمنة ، لأها رأت أن شيلة قد ولد كبر و لم تزوج به ـ فرآها يهوذا فحسبها باغيا، لأها كانت مغطية وجهرها ـ فمال إليها إلى الطريق وقال : هلم أدخل عليك ، لأنه لم يعلم أها كنته ـ فقالت له :

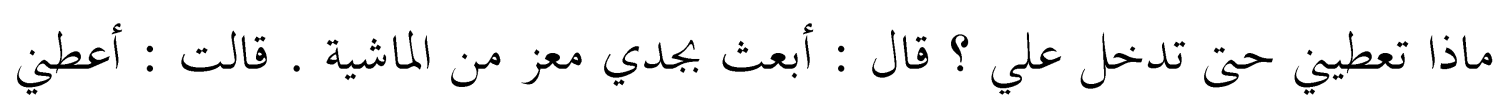
رهنًا إلى أن تبعث. قال ما الرهن الذي أعطيكه؟ قالت : خحاتمك وعقالك وعصاك التي بيدك ـ فأعطاها ودخل عليها ، فحبلت منه ـ ثم قانت فمضت ونزعت خمارها من عليها ولبست ثياب إرماها ـ و وبعث يهوذا بجدي ماعز مع صاحبه العدلامي

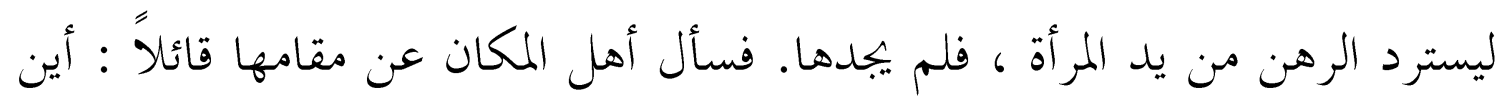
البغي التي كانت عند العينين على الطريق؟ قالو ا: ما كانت هاهنا قط بغي)(")

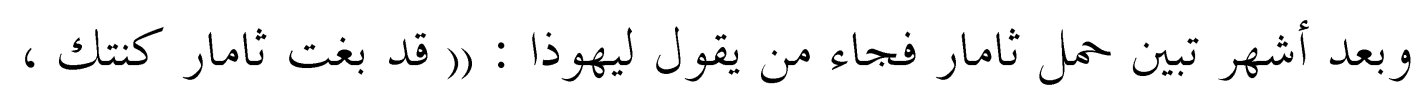
وها هي حامل من البغاء. فقال يهوذا : أخرجوها فتحرق . فبينما هي غخرجة بعثت إلى حميها قائلة: من الرجل الذي هذه الأشياء له أنا حامل. وقالت

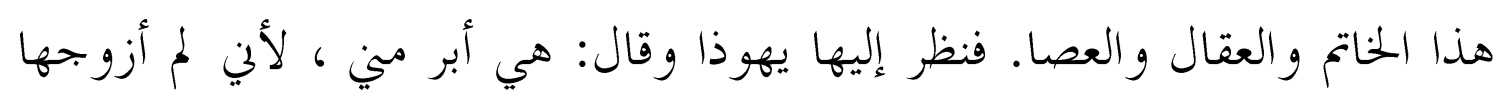
لشيلة ابني ()(r) (ب)

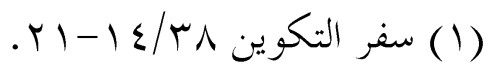

$$
\begin{aligned}
& \text { (Y) نفسه م/r }
\end{aligned}
$$


ولعلَّ ممارسات البغايا من بقايا تلك الممارسات التي كانت لها علاقة على ما يبدو بظاهرة البغاء المقدس في المعابد القديمة من بينها الكعبة. و كان البغاءُ موجوداً عند معظم الشعوب القديمة والمتحضرة ، حتى إنّ بعض الدول كانت تنظم شؤون

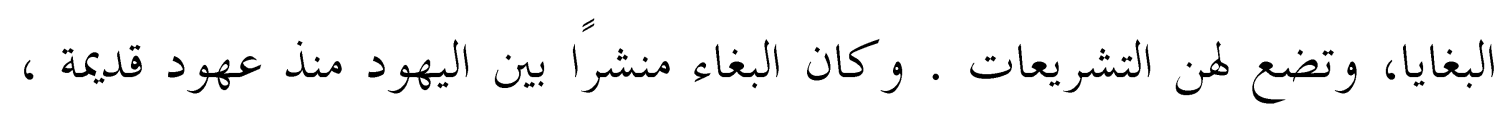
كما يوحي به هذ النص : (( لا تدنس ابتك بتعريضها للزفن )(").

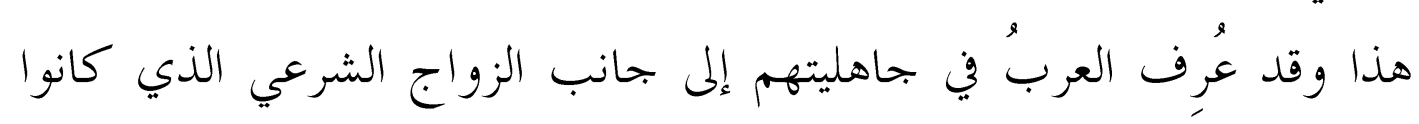

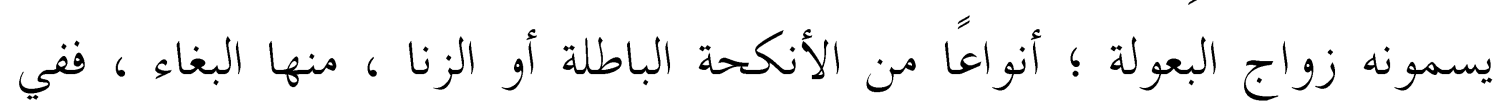

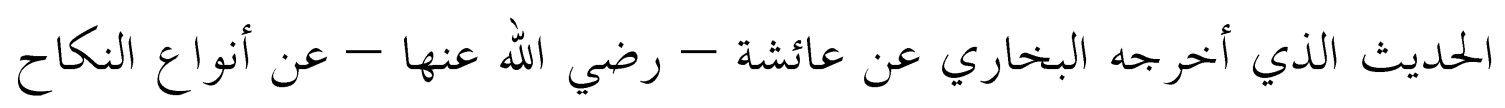

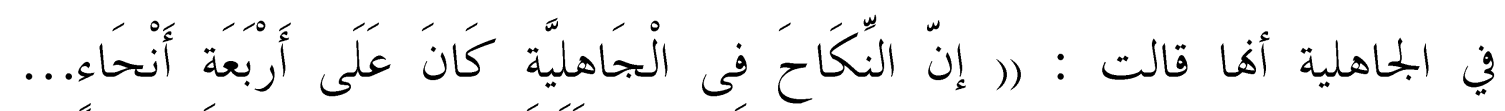

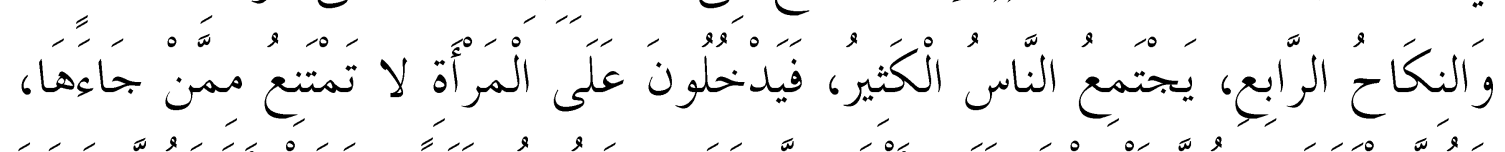

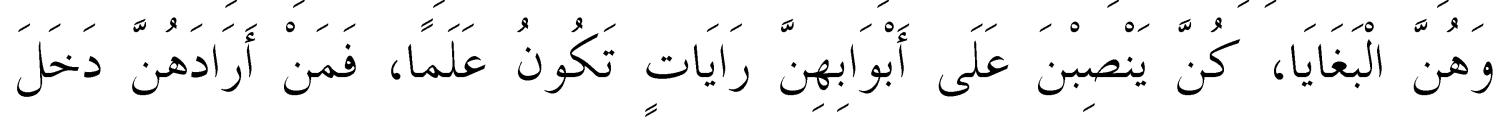

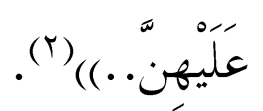

وظلَّ البغاءُ عند مشركي العرب حتى بعد ظهور الإسلام ، كان لعبدالله بن أبي

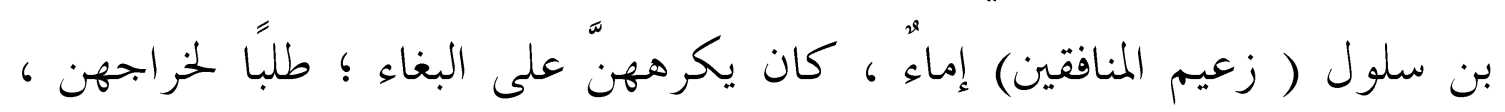
فأنزل الله تعالى هذه الآية .

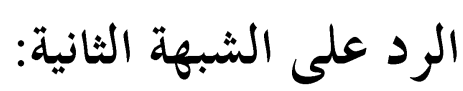

قالوا : إنّ سياق الآية يدعو إلى البغاء لمن لم تردن التحصن بدلالة منطوق اليه المخالفة (ومن لم تردن التحصن فلها أن تبغي) .

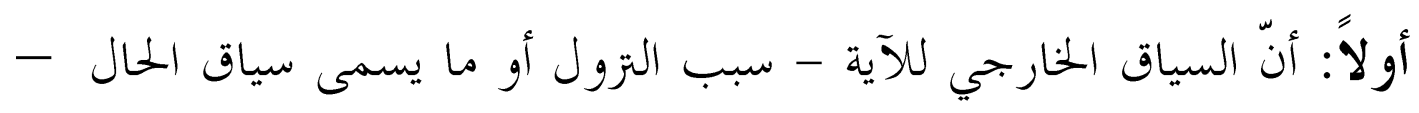

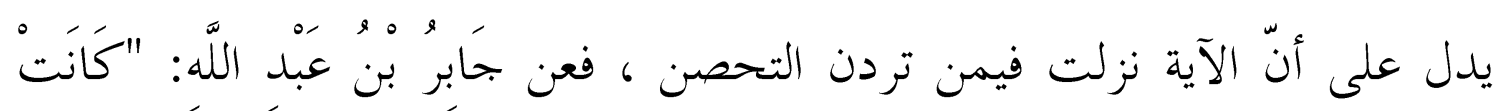

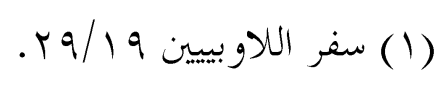

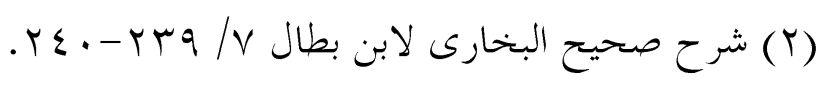




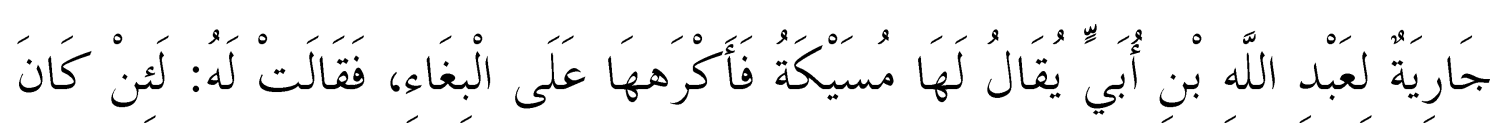

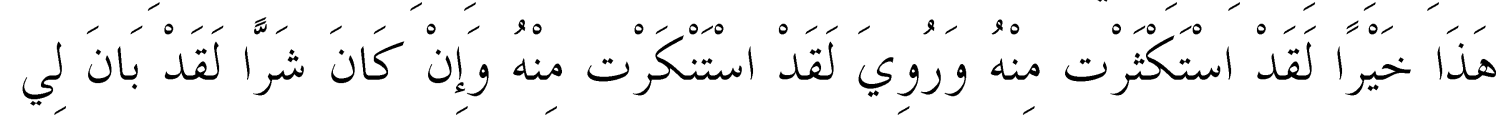

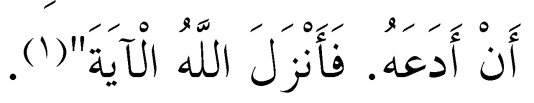

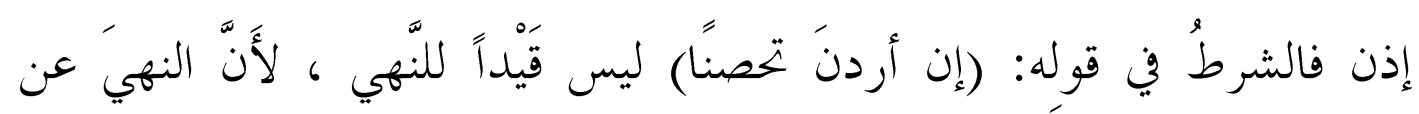

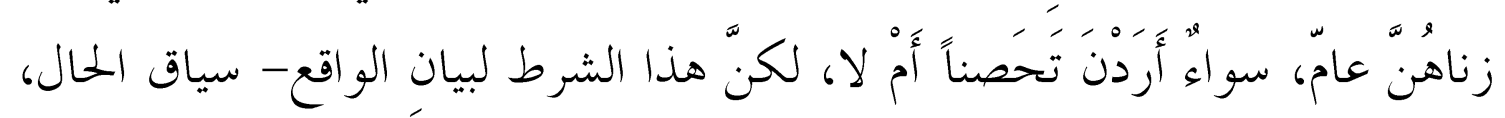

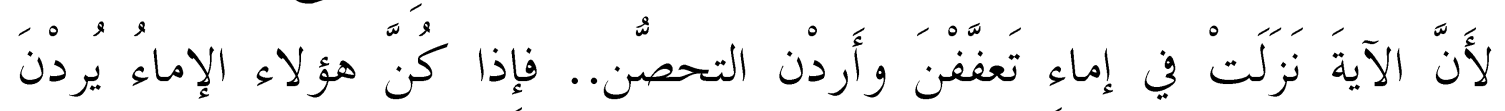

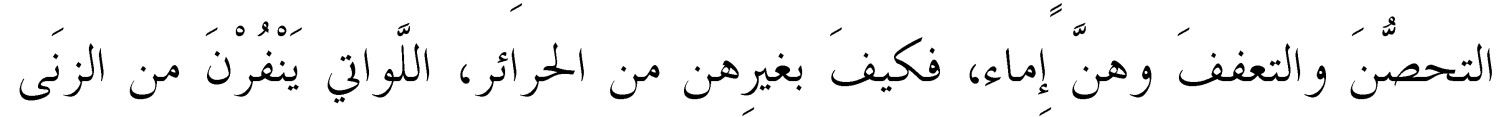
أساساً؟!. فالآية خاصة في التزول عامة في الحكم. وهذا يعنى أن البغاء مع عدم الإكراه

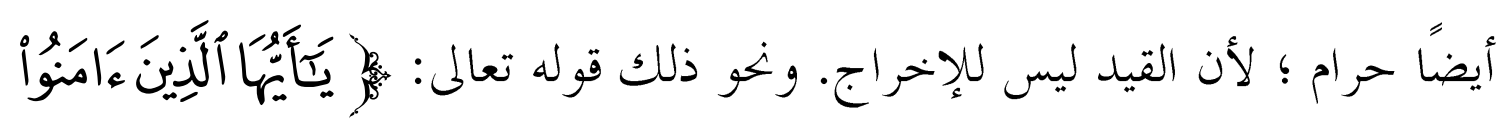

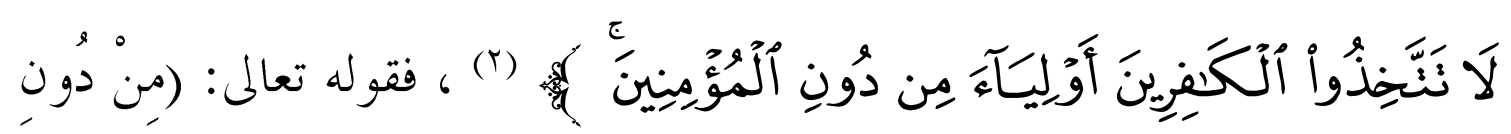

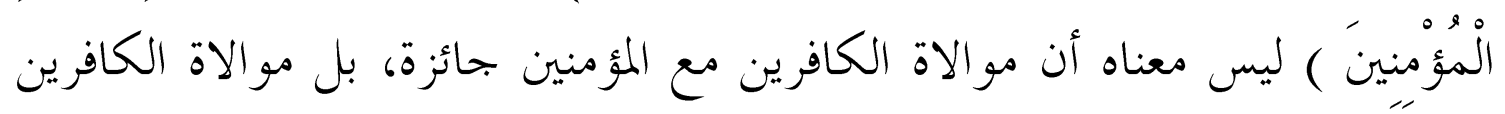
على كل حال حرام.

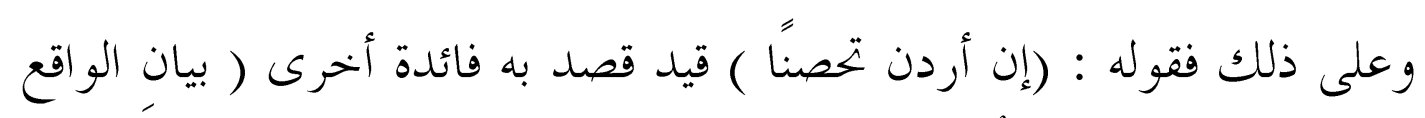

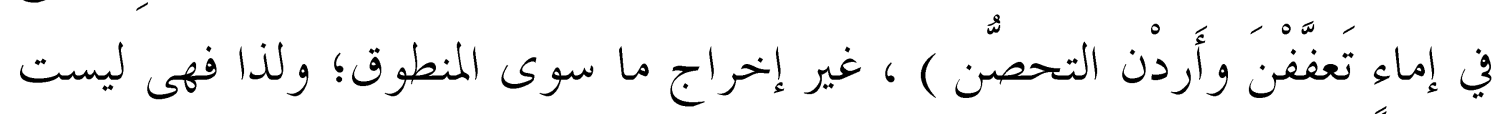
لها مفهوم مخالفة. ثانياً: أنّ وجود (( الإكراه )) - في سياق الآية - يدل على أنه لا يتأتى الإكراه

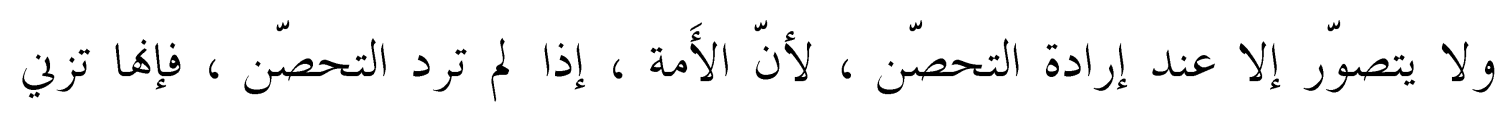

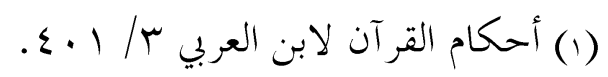

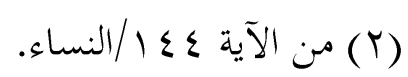




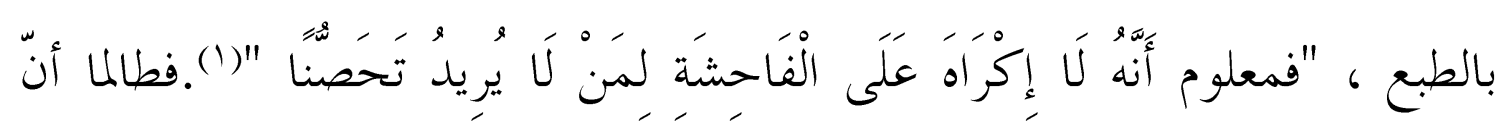
هناك إكراهًا ، فلابد أن يكون هناك إر ادة تحصن.

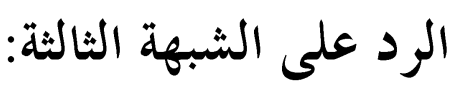

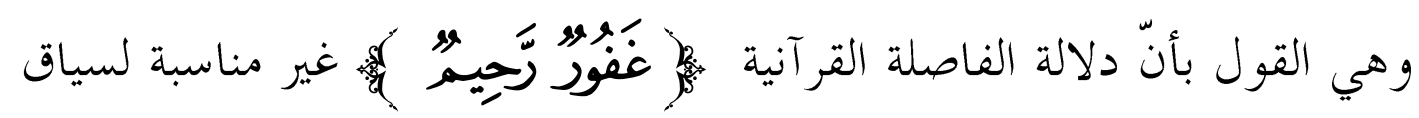
الآية ، و كان الأَوْلى أنْ يقول: (فإن الله شديد العقاب) بأسلوب العقاب و التهديد. وهؤلاء أعماهم التعصب عن إبصار الحق المبين ؛ لإن الفاصلة القر آنية (غفور

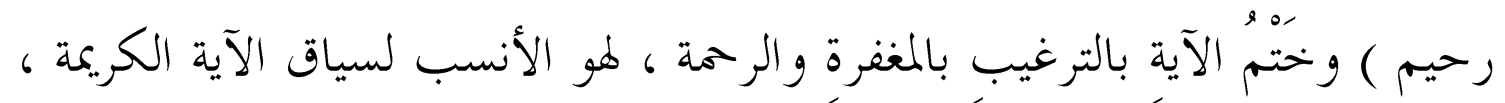
ففي الآية (بحاز بالحذف) أي غفور لهن رحيم هن. ومما يؤيد ذلك قوله تعالى: (من

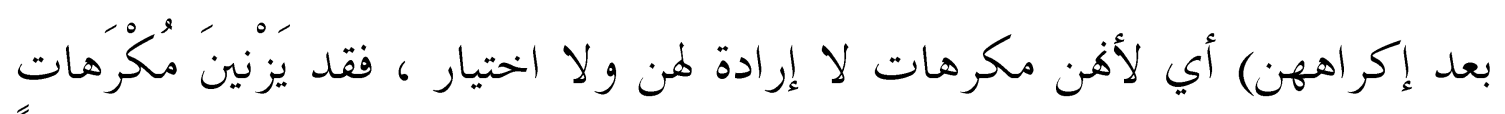

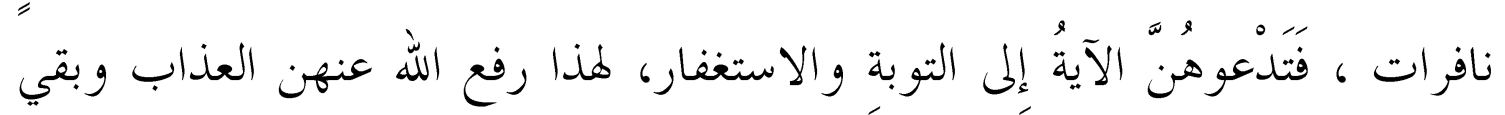

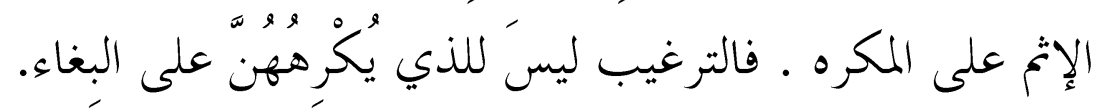

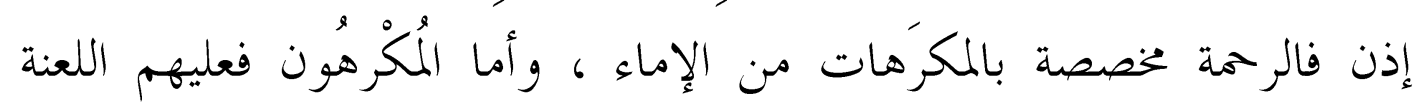

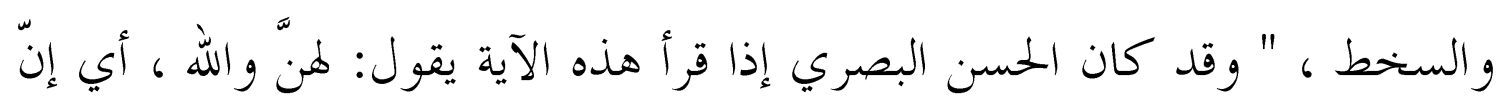
الله غفور لهن ، لا لأولئك المجرمين الذين أكرهوا النساء على البغاء"(؟).

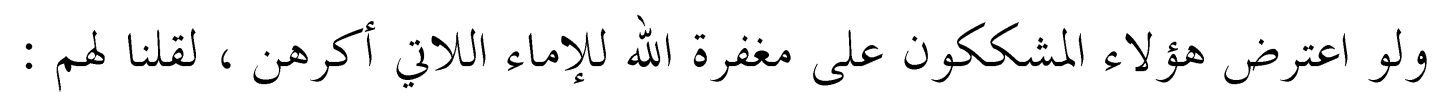
إنّ المغفرة على مذهب الكتاب المقدس مكفولة لكل الذنوب إلا التجديف (الإهانة والشتم) في حق الروح القدس ، مما يدخل إجبار الإماء على الزنا من باب الذنوب

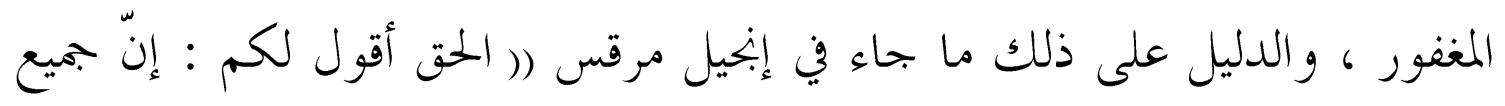


الدلالة اللغوية بين رقي القرآن وشبهات المستشرقين وجهلهم بإعجاز اللفظ القرآني.

الخطايا تغفر لبني البشر و التَّجاديف التي يجدفوها..وركن من جدّف على الروح

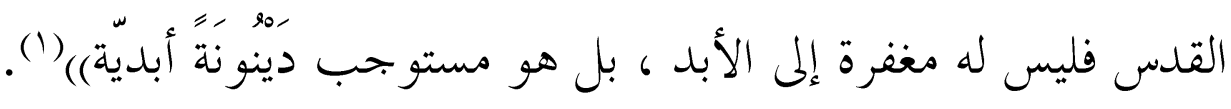

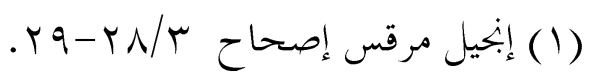




\section{المبحث الثامز : في دلالة لفظة : (البهتان):}

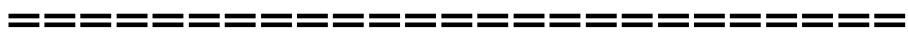

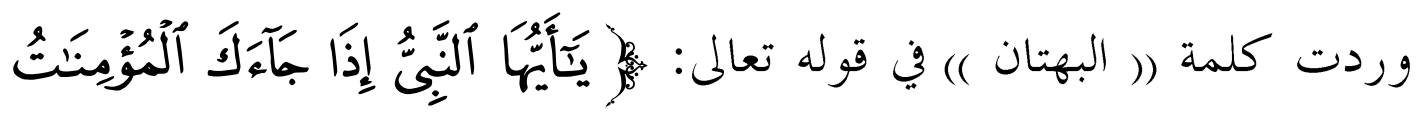

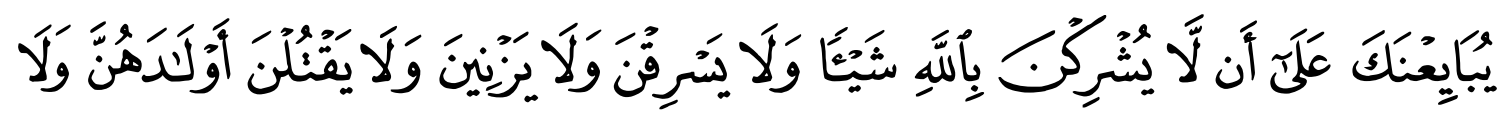

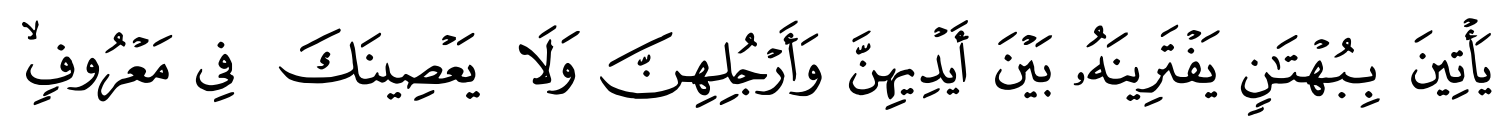

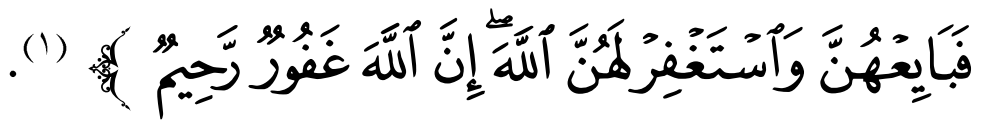
وقد اعترض أعداء الإسلام على تفسير لفظ البهتان بالزنا ، مستدلين بقول الراغب : البهتان "كناية عن الزنا"(r)، قائلين : كيف يأتي لفظ (( البهتان )) و ويراد به الزنا ، وقد تقدم عليه قوله : (و لا يزنين) ، و الشيء لا يعطف على نفسه؟. و الحق أنّ هؤلاء قد غاب عنهم المعنى الدلالي الأصلي للفظة (( البهتان )) وربطه بالسياق الوارد فيه . فالبهتان : اسم من البهت ، ووهو مأخوذ من مادة (ب هــ ت) التي يدور معناها حول الدهش و الحيرة ، وتتصل فروعها بهذا الأصل وتتقارب ، يقول ابن

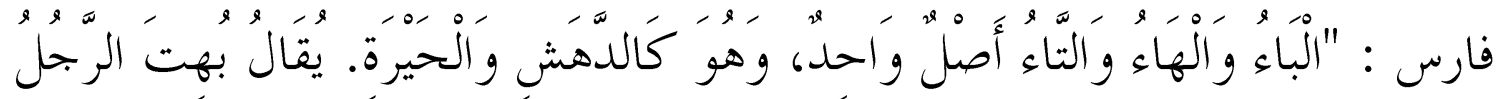

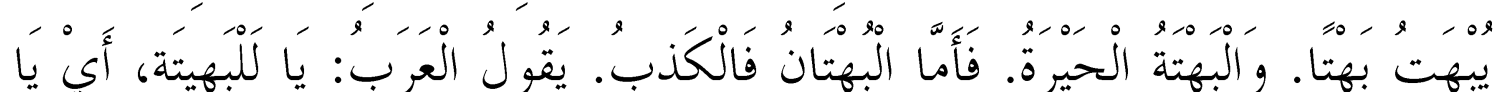

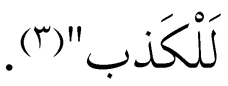

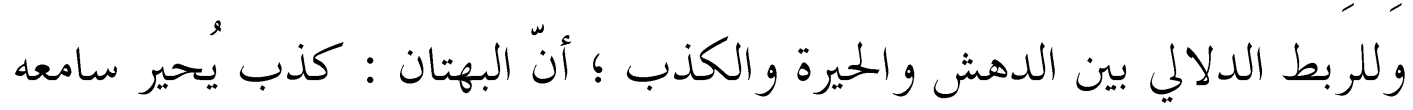


لفظاعته و كذلك "الافتراء الباطل الذي يتحَير من بطلانه لزيادة الفُحش فيه"(1)"،

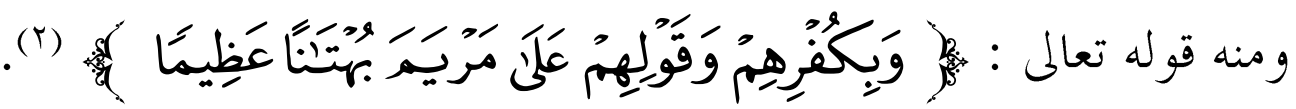

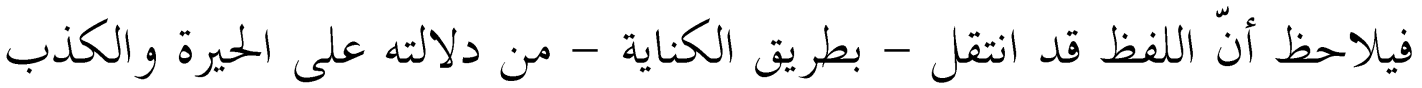
وأصبح يدل في سياق الأية - محل البحث - على ما كان يحدث في الجاهلية من

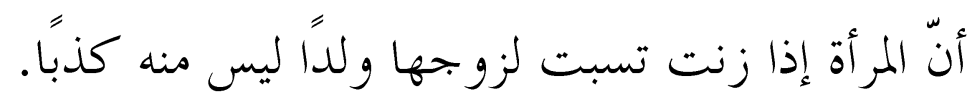
إذن فالبهتان في سياق الأية ليس المقصود به الزنا - كما تصور هؤلاء - ، كرون لكنه كناية عما نتج من الزنا وهو الولد ، وليس كناية عن الزنا نفسه ؛ لأنّ المرأة الزانية من الممكن أن تزبي و لم تنجب من الزنى فاحتاط القرآن فذكر الزنا و البهتان . L ومما يدل على أنّ المراد بالبهتان أنه نتاج الزنا (الولد الكذب) وليس الزنا نفسه، دلالة معطيات السياق من مفردات تدل على ذلك . فقد جاء في السياق كلمة ( بين - أيديهن - أرجلهن ) ، وهذه الكلمات تتعلق بــ(( يأتين )) ، كما أنّ البهتان مصدر ، ومن الممكن أن أن يطلق المصدر ويراد به اسم المفعول فيقال : (( مبهوت ()(معنى : (( مكذوب )) ، مثل : (ر خلق .كعىن

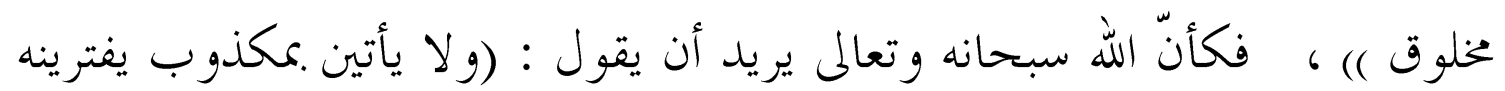

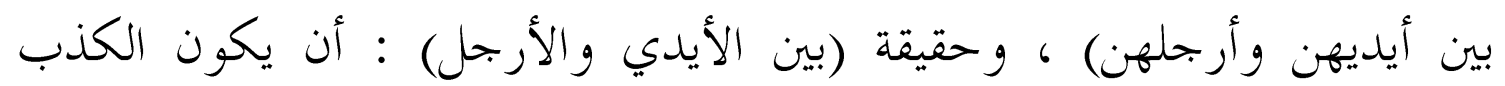

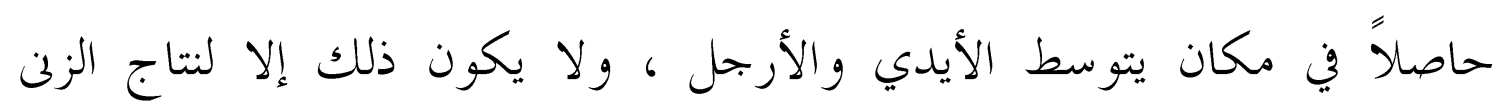

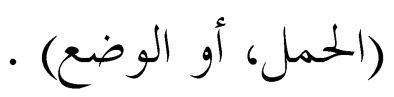


فيكون القرآن قد " كنّى بالبهتان المفترى بين يديها ورجليها عن الولد الذي

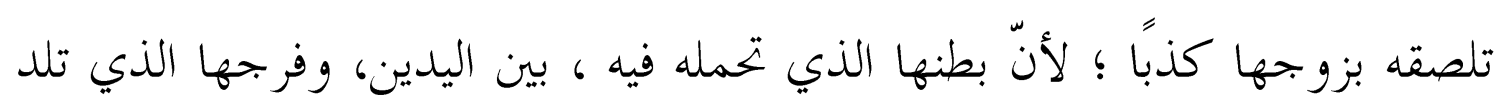

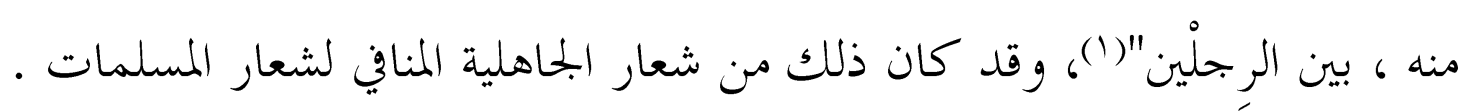
الأسرار الدلالية في اختيار لفظة (( البهتان )) لسياق الأية الكريمة:

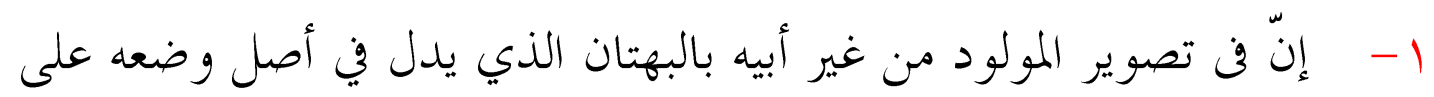
الحيرة و الدهشة ، دلالة على حيرة الزوج ودهشته عند سماعه لهذا الافتراء

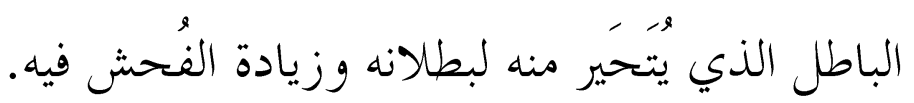

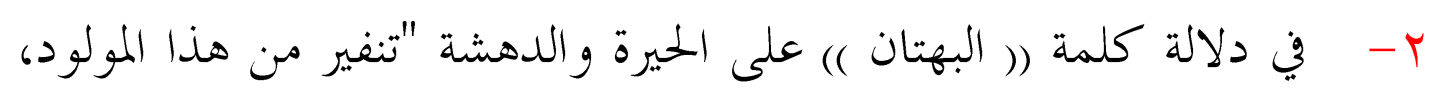

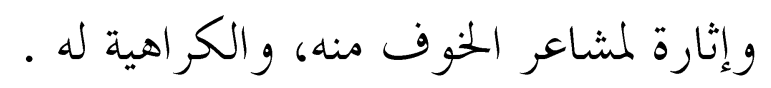

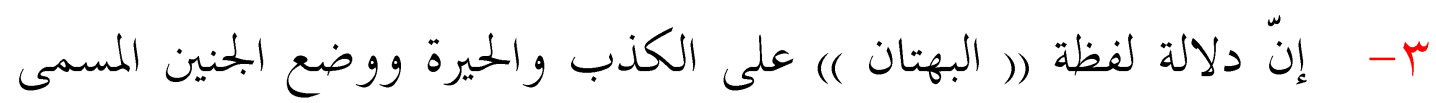

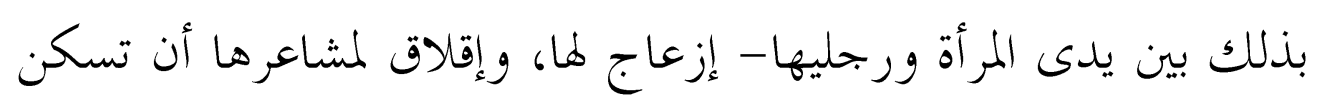
إلى هذه الجريمة البشعة التي تعيش معها، كما يعيش القتيل بين يدى بـى قاتله.. ع- - إنّ كون هذا البهتان بين يدى المرأة ورجليها، يعيش في بطنها تسعة

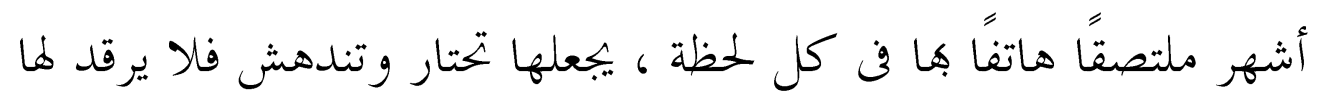
جفن و لا يهدأ لما بال. ه- - إذا علمت المرأة أنّ ما في بطنها بهتان - لا يد ع لها لحظة من الاستقرار و السكون، في يقظة أو منام، الأمر الذي يدعوها إلى التفكير الطويل قبل

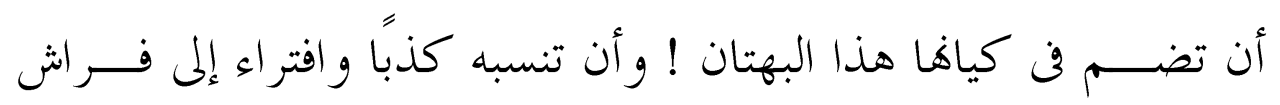

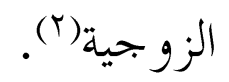

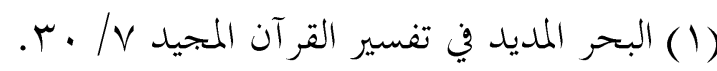

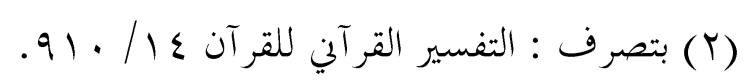




\section{الخاتنهة}

وبعد ، فهذه رحلة امتزجت فيها حلاوة العلم بنور القرآن في الوقوف على

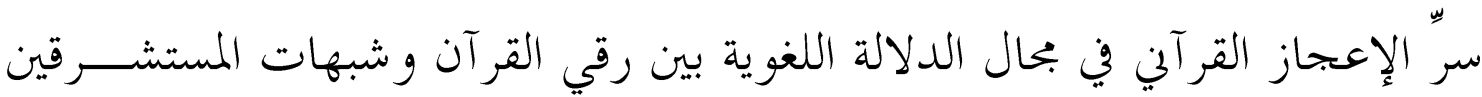
حول ألفاظ العلاقات الجنسية المحرمة .

ولاشك أنّ الباحث في علم كعلم إعجاز القرآن يكون أكثر العباد إيمانًا

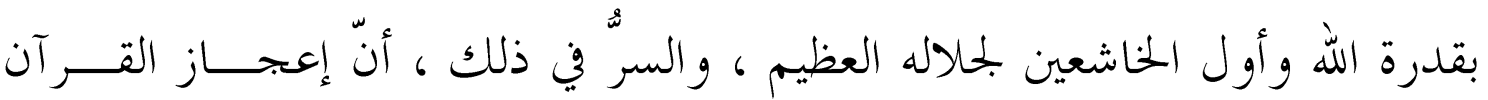
الكريم المتمثل في ألفاظه وأساليبه ومعانيه يأسر العقول ويدفعها إلى التفكير فيسـه ،

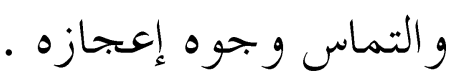

هذا وقد وصل الباحث إلى الكثير مــن النتــائج موزعــة في صــفحات الأطروحة، ومن أهم هذه النتائج ما يأتي:-

1- إبرز البحث أوجه الإعجاز القر آني في التناســب الــــلالي لألفـــاظ

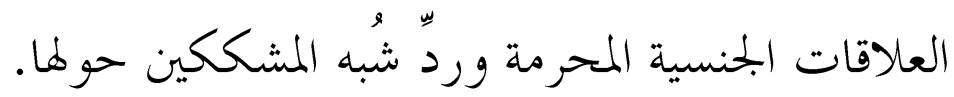

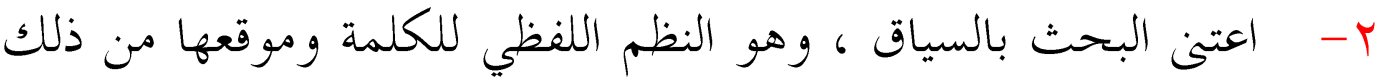

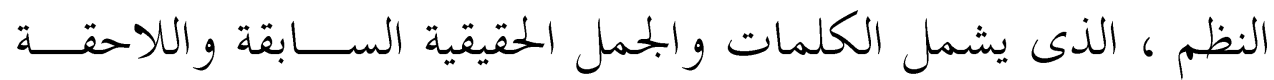

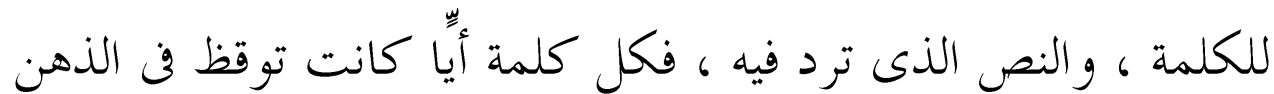
صورة ما ، حسنة أو قبيحة ، هيجة أوحزينة ، راضية أوكريهة ، فهو

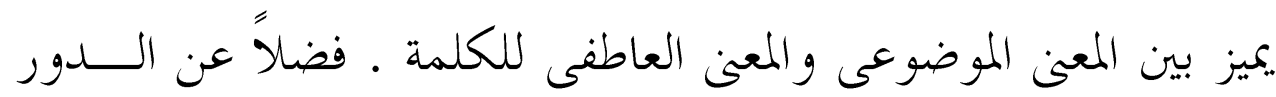

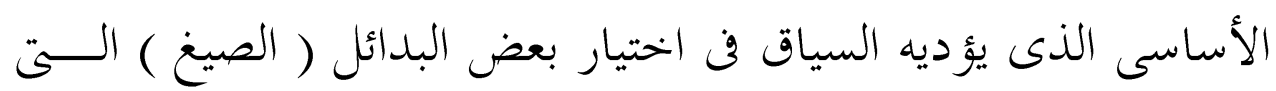
تعطي ملامح دلالية في السياق الواردة فيها. r- - وقف البحث على كثير من أسرار الإعجاز اللغوي المتمثلة في اللفظة

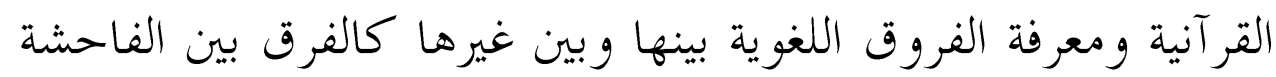

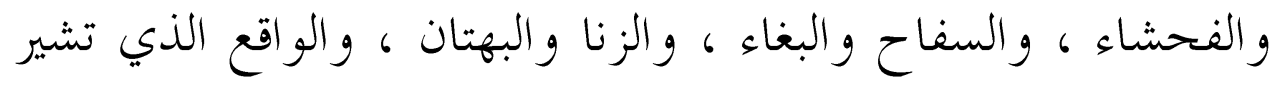


إليه هذه الكلمات، ولا يمكن الوقوف على هذه الأسرار إلا عن

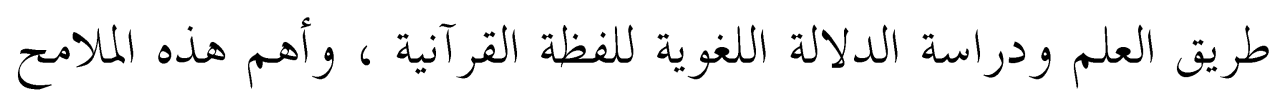

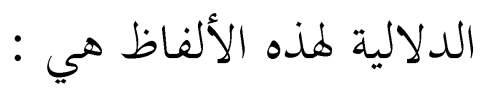
- كلمة (( الفاحشة )) تركز على ملح القبح الشديد في عملية الزنا

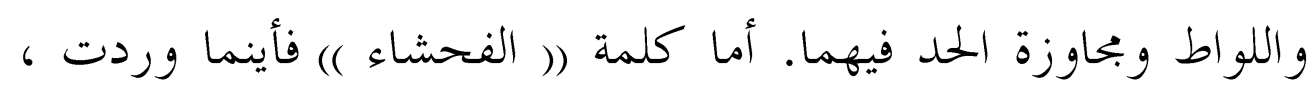

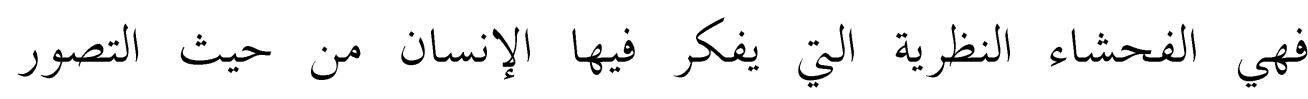

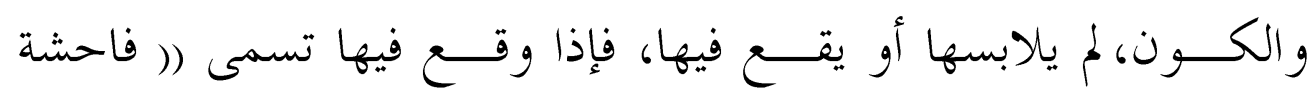

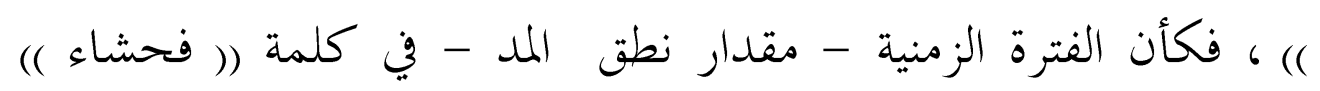

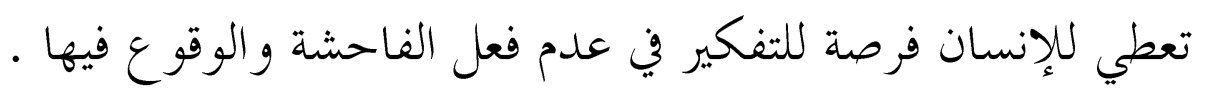

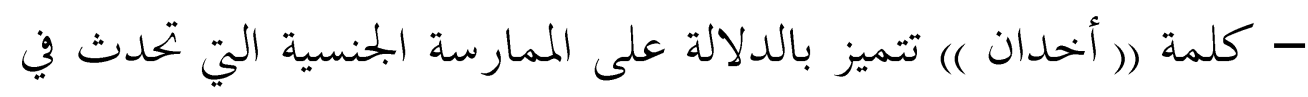

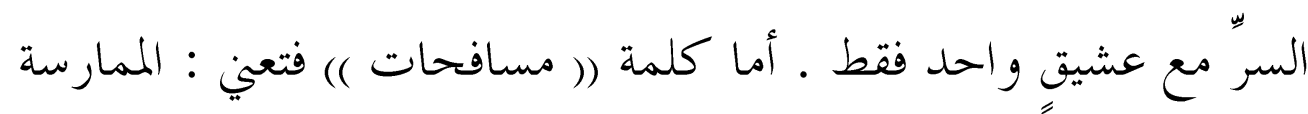

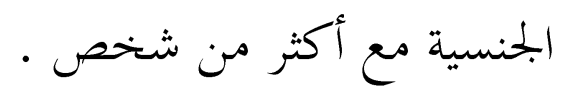
- تركيب (( ظاهر الإثم )) يتميز بملمح الإعــانلان والجهر بعملية الزنا.

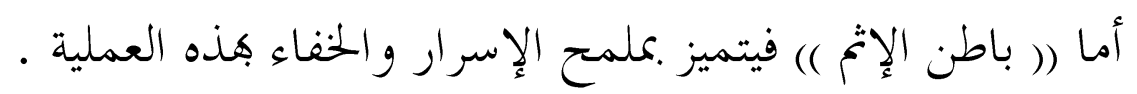

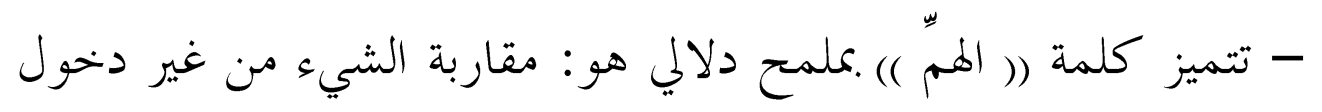

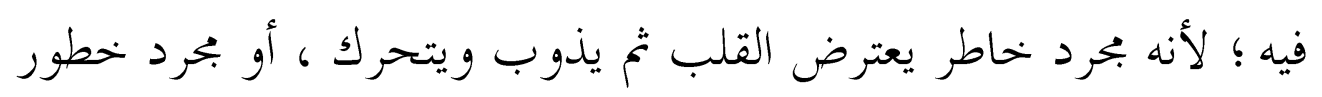
الشىء في البال ، و إن لم يقع العزم عليه.

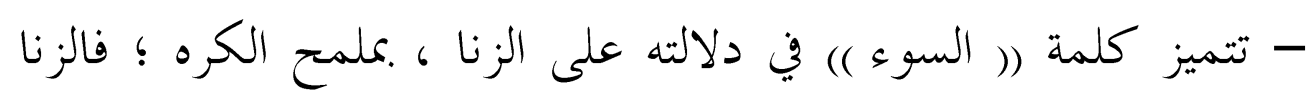
شيء مكروه تكرهه الطبيعة . - كلمة (( زنا )) تحمل ملمحًا دلاليًا ميزًا ا وهو (( الضيق )) ، و كأن الز الني

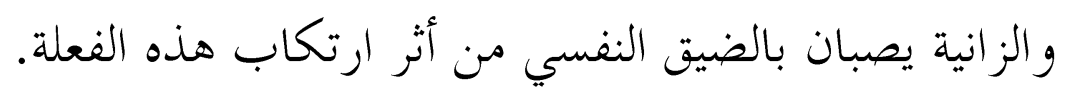


- يتميز لفظ (( البغاء )) في دلالته على الزنا بملامح هي : أنّ البغاء :

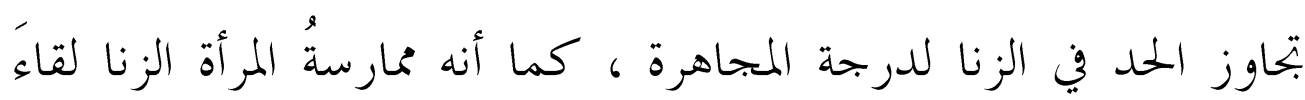

أجر، فإن خلا من الأجر والحاجة فهو الزنا ، كما يختص بزنا النساء فلا

$$
\text { يقال للرجل إذازنا : إنه بغى. }
$$

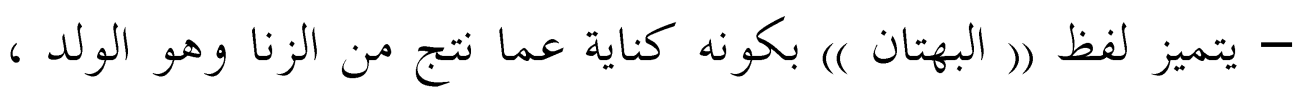

$$
\text { وليس كناية عن الزنا نفسه . }
$$

ع - أثبت البحث أنّ السياق هو الموجه الأساسي في اختيار اللفظة القرآنية

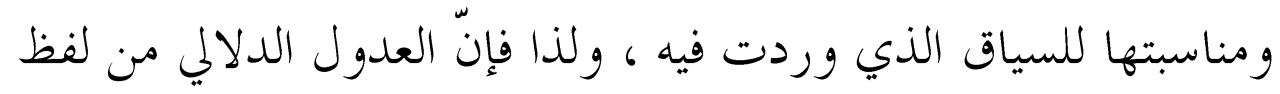

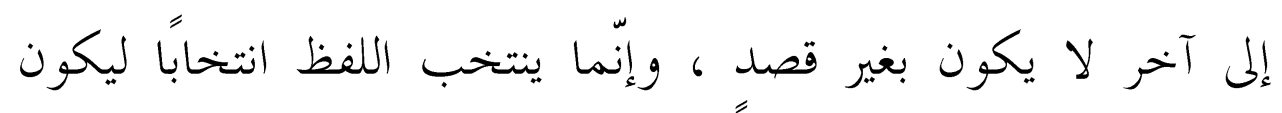

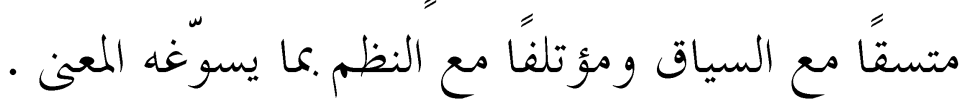

\section{وبعد}

فعسى أن يكون في النصوص التي جمعتها وذكرت مصــادرها ، وشـــرحتها

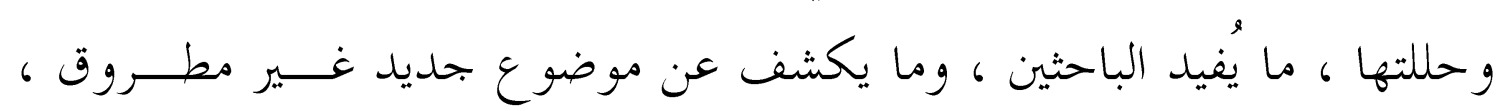

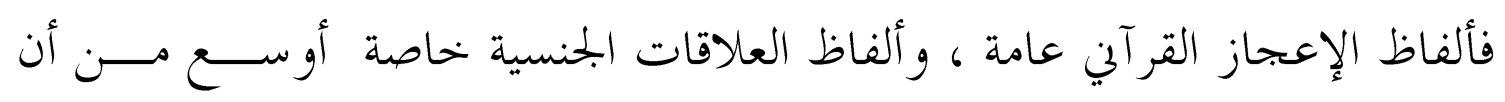
تحيط بها در اسة عابرة . ولا أدعي أني بهذا البحث قد بلغت درجة الكمال ، فالكمال للّه وحده ـ فإن إن

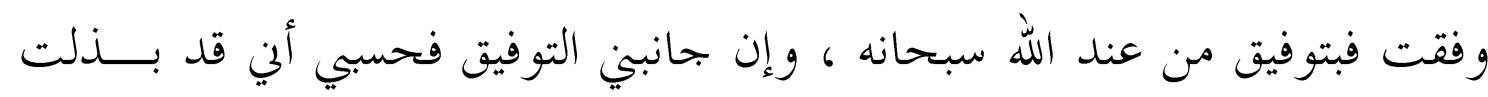

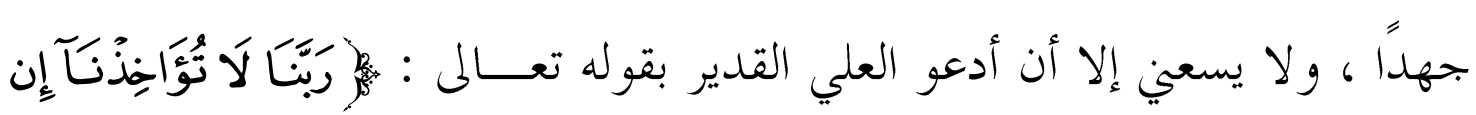

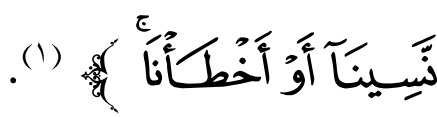
و الحمد لله أولاً و آخراً وصلى الله على سيدنا محمد وعلى آله وصحبه وسلم. 


\section{ثنبت المصادر والمراجم}

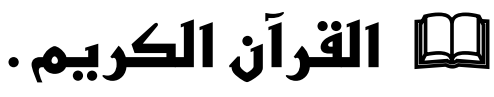 الكتب العلمبة}

1- أحكام القرآن لابن العربي ، المؤلف: القاضي محمد بن عبد الله أبو بكر

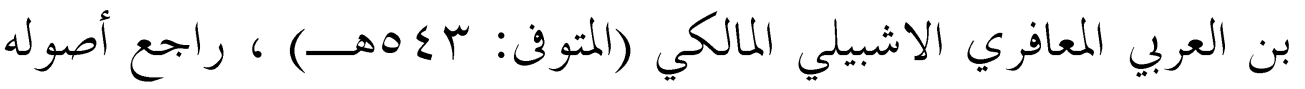

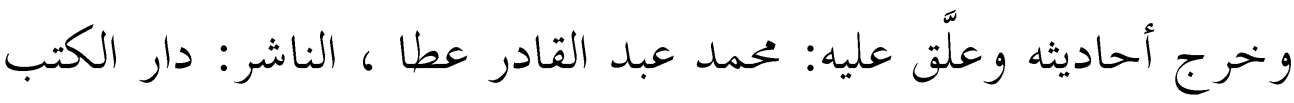

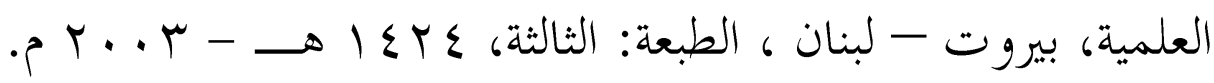

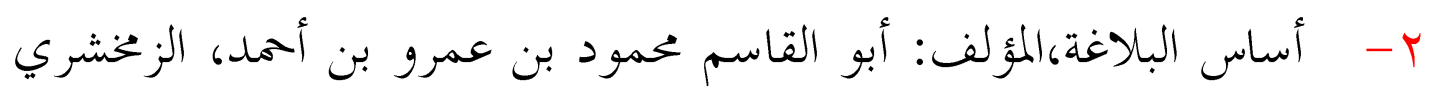
جار الله (المتوفي: مبههـ)،تحقيق: محمد باسل عيون السود ، الناشر:

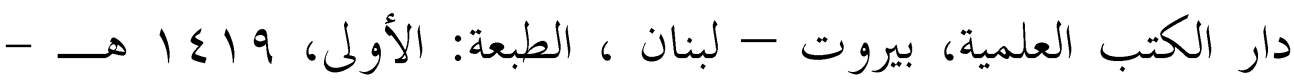
.01991 r- الإسرائيلات والموضوعات في كتب التفسير، المؤلف: محمد بن محمد بن

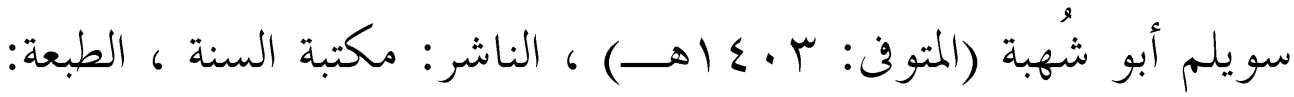

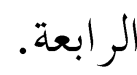

ع- الإعجاز العلمي في الإسلام ، المؤلف : محمد كامل عبد الصمد ، الدار

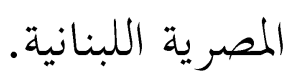

ه- إعراب القرآن للأصبهاني ، المؤلف: إسماعيل بن محمد بن الفضل بن علي

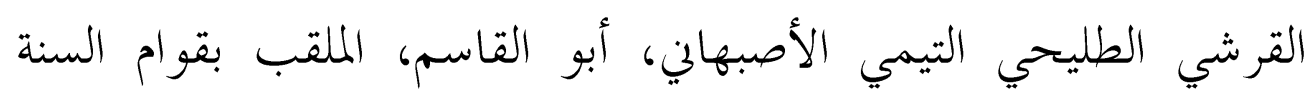
(المتوفن: 0بههـ) ، قدمت له ووثقت نصوصه: الدكتورة فائزة بنت عمر المؤيد ، الناشر: غير معروف (فهرسة مكتبة الملك فهد الوطنية -

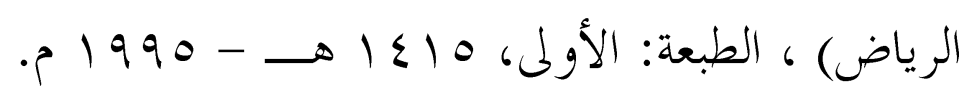

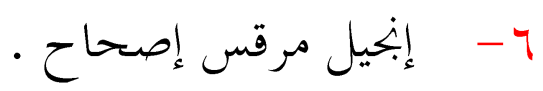


- V

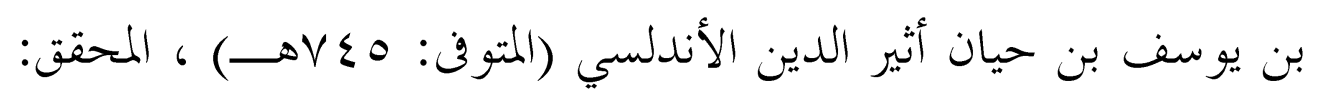

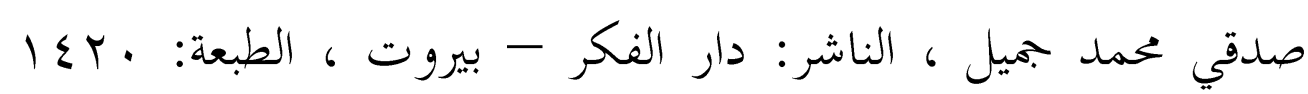

人- - البحر المديد في تفسير القرآن المجيد ، المؤلف: أبو العباس أحمد بن محمد بن المهدي بن عجيبة الحسين الأبخري الفاسي الصوفي (المتوفى:

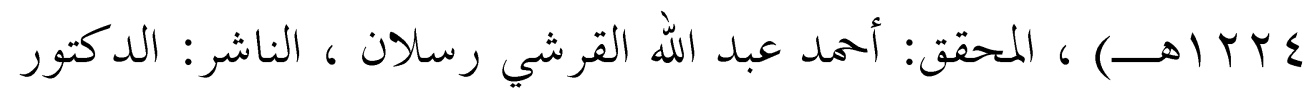

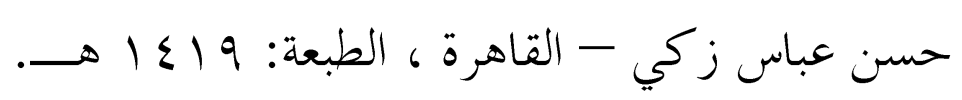
9- - البرهان في علوم القرآن المؤلف: أبو عبد الله بدر الدين محمد بن عبد الله

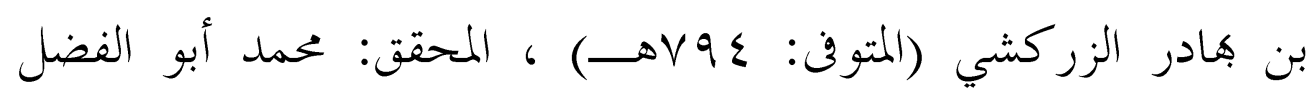

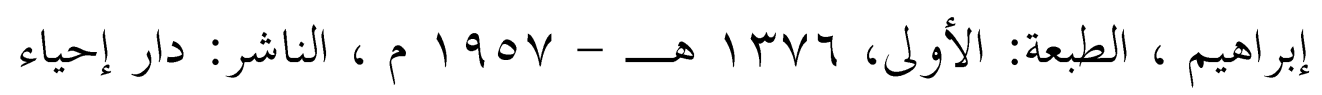
الكتب العربية عيسى البابى الحلبي وشر كائه.

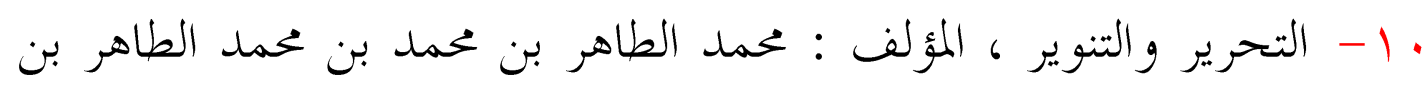
عاشور التونسي (المتوفى : بو ץ اهــ) ، الناشر : الدار التونسية للنشر

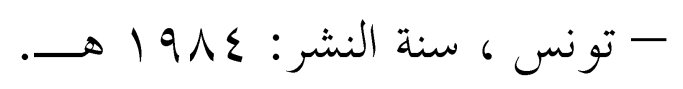
1 - إتفسير البغوي ، المؤلف : محيي السنة ، أبو محمد الحسين بن مسعود بن

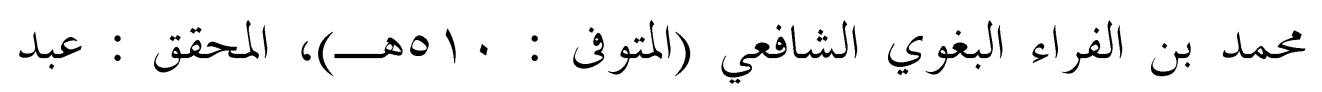
الرزاق المهدي ، الناشر : دار إحياء التراث العربي - سبيروت ، الطبعة :

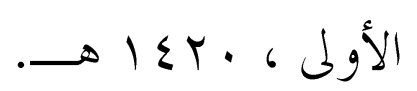
r ا - تفسير البيضاوي ، المؤلف: ناصر الدين أبو سعيد عبد الله بن عمر بن

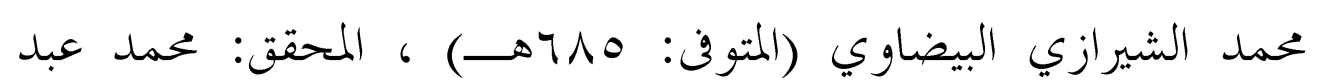


الرحمن المرعشلي ، الناشر: دار إحياء التراث العربي - بيروت ، الطبعة:

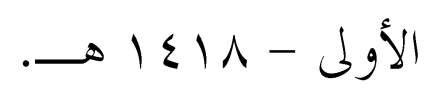

rا - تفسير الثعبي ، المؤلف: أحمد بن محمد بن إبراهيم الثعبي، أبو إسحاق (المتوفى: SYV وتدقيق: الأستاذ نظير الساعدي ، الناشر: دار إحياء التراث العربي،

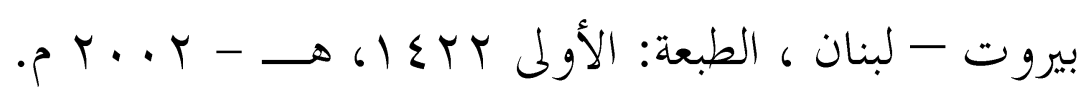
ع ا- تفسير الخازن لباب التأويل في معاني التنزيل ، المؤلف: علاء الدين علي بن محمد بن إبراهيم بن عمر الشيحي أبو الحسن، المعروف بالخازن

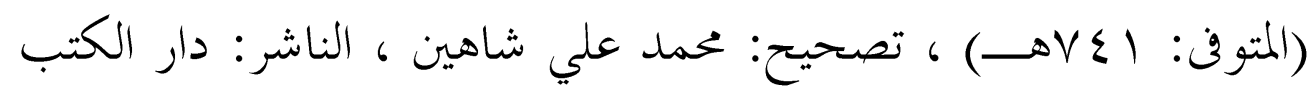

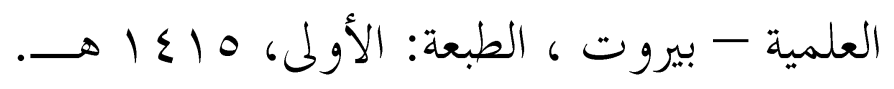

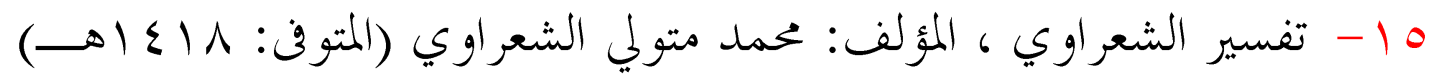
6 الناشر: مطابع أخبار اليوم. توبرير. 17

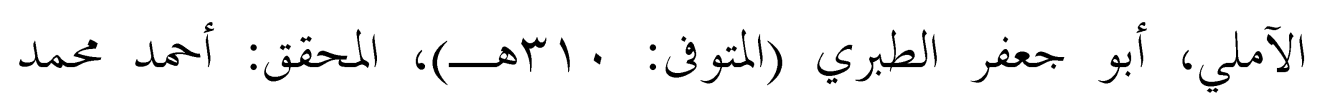

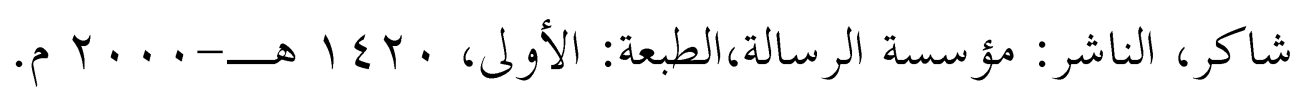
V ا - التفسير القرآي للقرآن ، المؤلف: عبد الكريم يونس الخطيب (المتوفى: بعد · وب (هــ)، الناشر: دار الفكر العربي - القاهرة. 11 - تفسير الماوردي ، المؤلف: أبو الحسن علي بن محمد بن محمد بن حبيب

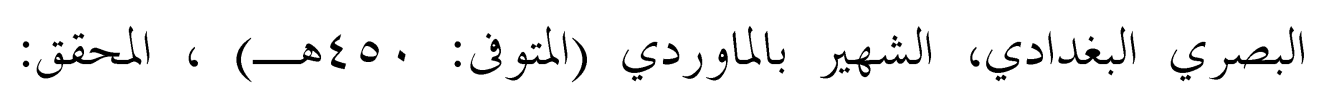
السيد ابن عبد المقصود بن عبد الرحيم ، الناشر: دار الكتب العلمية -

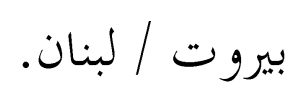


9 1 - التفسير المنير للزحيلي ، المؤلف : د وهبة بن مصطفى الزحيلي ، الناشر :

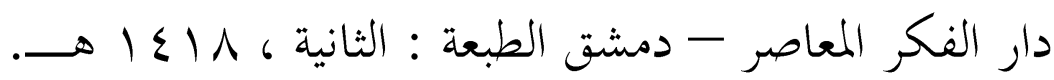
• ץ- تفسير آيات الأحكام للسايس ، المؤلف: محمد علي السايس الأستاذ بالأزهر الشريف ، المحقق: ناجي سويدان ، الناشر: المكتبة العصرية للطباعة و النشر . اץ - هذيب اللغة ، المؤلف: محمد بن أحمد بن الأزهري الهروي، أبو منصور (المتوفى: • • r.هـ) ، المحقق: محمد عوض مرعب ، الناشر: دار إحياء

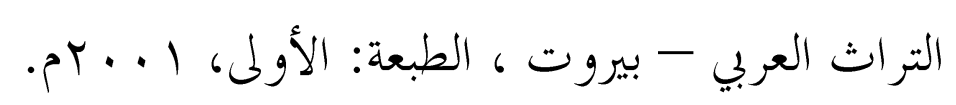
Y Y - التوقيف على مهمات التعاريف، المؤلف: زين الدين محمد المدعو بعبد الرؤوف بن تاج العارفين بن علي بن زين العابدين الحدادي ثم المناوي القاهري (المتوف: اسب (اهـ) ، الناشر: عالم الكتب مب عبد الخالق

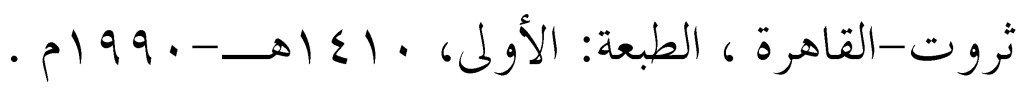

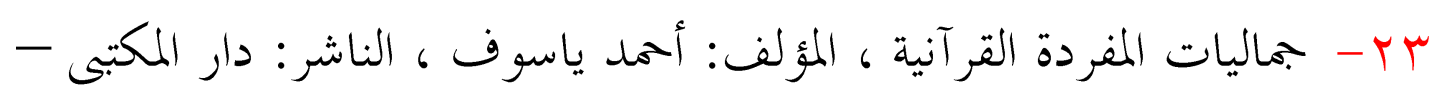

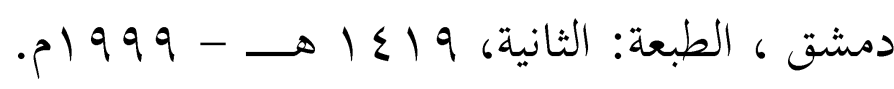
ع - - دلائل الإعجاز ، المؤلف: أبو بكر عبد القاهر بن عبد الرحمن بن محمد

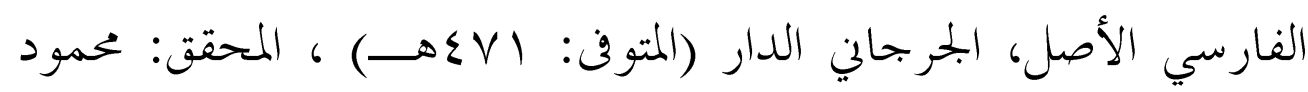
محمد شاكر أبو فهر ، الناشر: مطبعة المدني بالقاهرة - دار المدلي بجدة ، 6

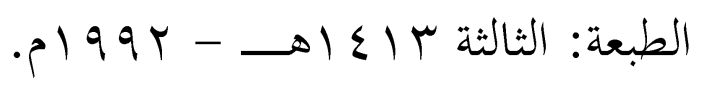
هץ - روائع البيان تفسير آيات الأحكام ، المؤلف: محمد علي الصابوبن ، طبع على نفقة: حسن عباس الشربتلي ، الناشر: مكتبة الغزالي - دمشق، مؤسسة مناهل العرفان - بيروت ، الطبعة: الثالثة، . . عـ هـ - 
ج ب- زهرة التفاسير ، المؤلف: محمد بن أحمد بن مصطفى بن أحمد المعروف بأبي زهرة (المتوفى: ع وباهــ) ، دار النشر: دار الفكر العربي.

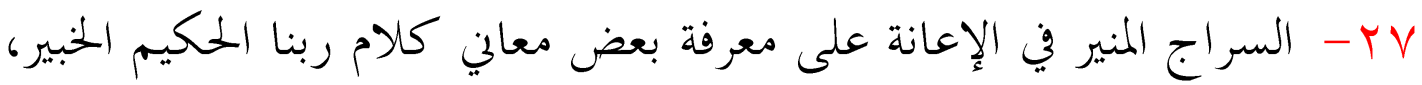
المؤلف: شمس الدين، محمد بن أحمد الخطيب الشربيني الشافعي (المتوفى:

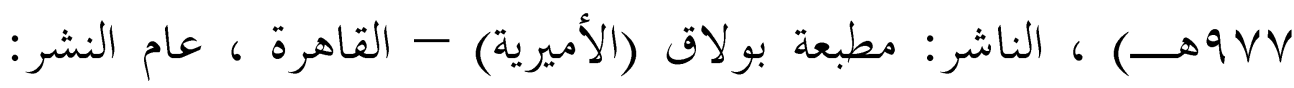

$$
\begin{aligned}
& \rightarrow 1 \text { Iro } \\
& \text { م ץ - سفر التكوين } \\
& \text { q - سفر اللاوبيين . } \\
& \text { • س- سفر حزقيال . }
\end{aligned}
$$

اب- السنن الكبرى للبيهقي ، المؤلف: أحمد بن الحسين بن علي بن موسى

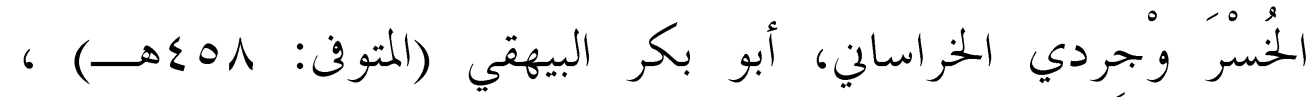
المحقق: محمد عبد القادر عطا ، الناشر: دار الكتب العلمية، بيروت -

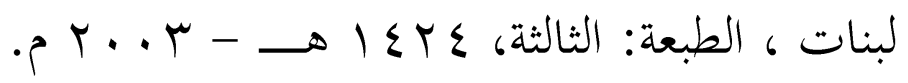
rr- شرح صحيح البخارى لابن بطال ، المؤلف: ابن بطال أبو الحسن علي بن خلف بن عبد الملك (المتوفى: 9؟§هــ)، تحقيق: أبو تميم ياسر بن إبراهيم ، دار النشر: مكتبة الرشد - السعودية، الرياض ، الطبعة:

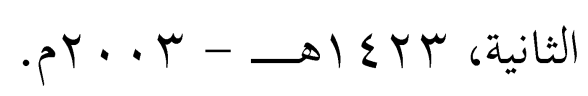

بr- صحيح مسلم،المؤلف: مسلم بن الحجاج أبو الحسن القشيري النيسابوري (المتوفى: آب هــ)،المحقق: محمد فؤاد عبد الباقي ، الناشر:

$$
\text { دار إحياء التراث العربي - بيروت. }
$$

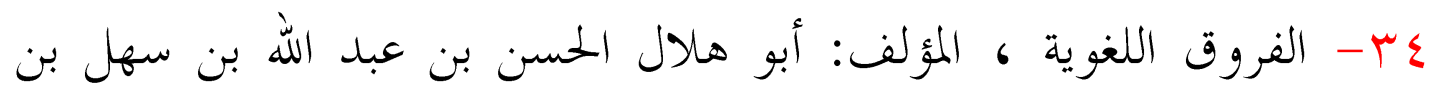

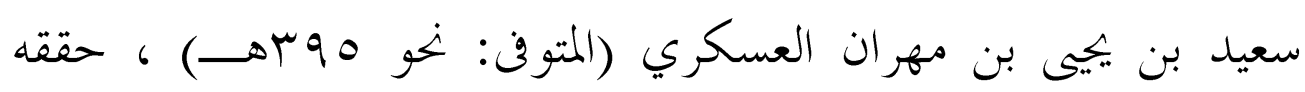


وعلق عليه: محمد إبراهيم سليم ، الناشر: دار العلم والثقافة للنشر

$$
\text { و التوزيع، القاهرة - مصر. }
$$

هـ- في ظلال القرآن ، المؤلف: سيد قطب إبراهيم حسين الشاربي (المتوفى:

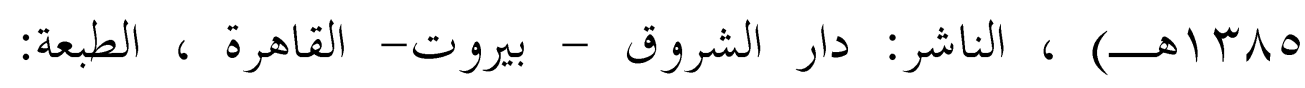

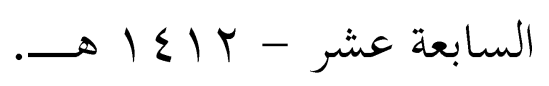

ب - القاموس المحيط ، المؤلف: بحد الدين أبو طاهر محمد بن يعقوب

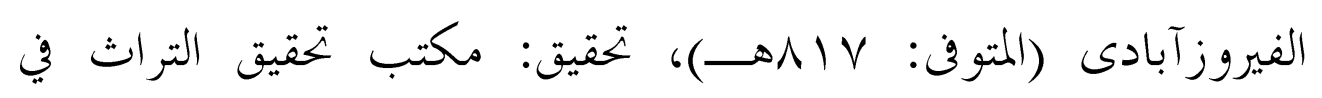

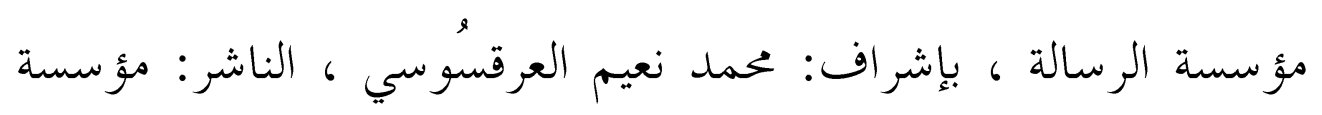
الرسالة للطباعة والنشر و التوزيع، بيروت - لبنان ، الطبعة: الثامنة،

$$
\text { . }
$$

TV - لسان العرب ، المؤلف: محمد بن مكرم بن على، أبو الفضل، جمال الدين

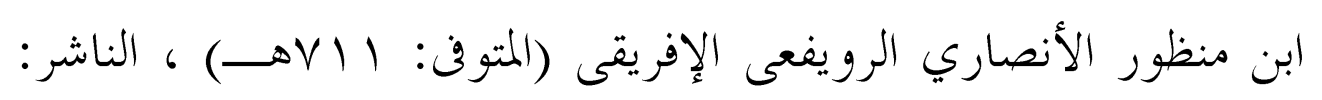

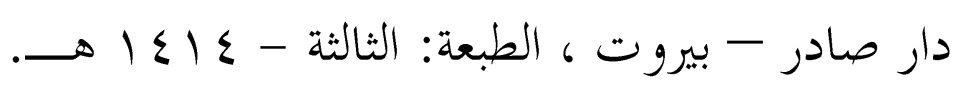
مץ-- المشترك اللفظي في الحقل القرآي ، المؤلف : عبد العال سالم مكرم

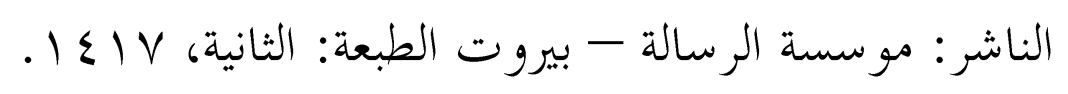

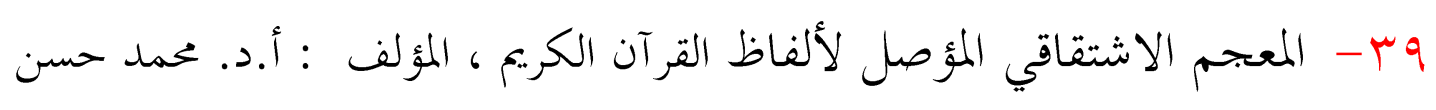
جبل ، مكتب الآداب ، الطبعة الثانية.

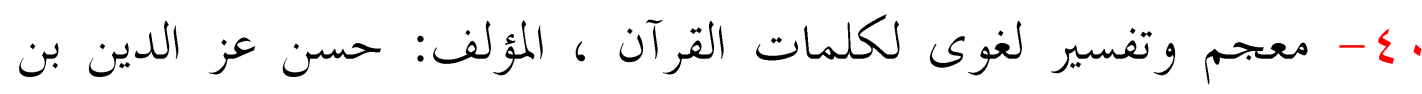

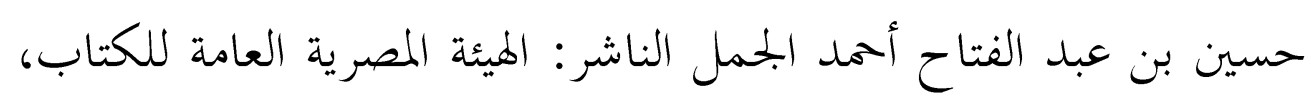

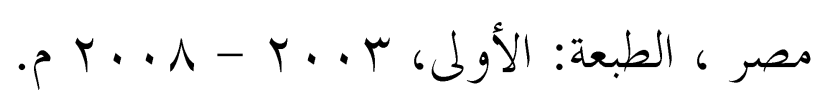

اع- المفردات في غريب القرآن ، المؤلف: أبو القاسم الحسين بن محمد

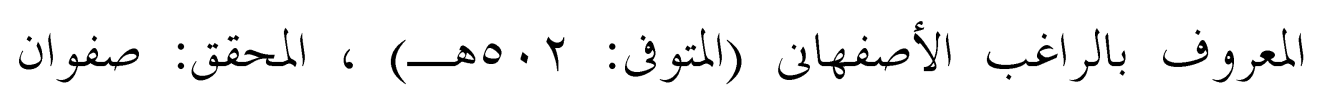


عدنان الداودي ، الناشر: دار القلم، الدار الشامية - دمشق بيروت ،

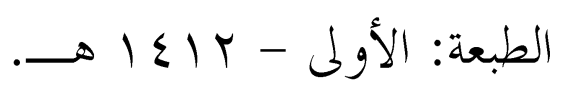
rع - مقاييس اللغة ، المؤلف: أحمد بن فارس بن زكرياء القزويني الرازي، أبو الحسين (المتوفى: 9 بهــ)، المحقق: عبد السلام محمد هارون ، الناشر:

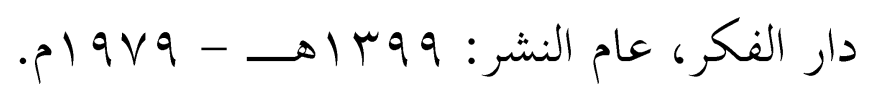

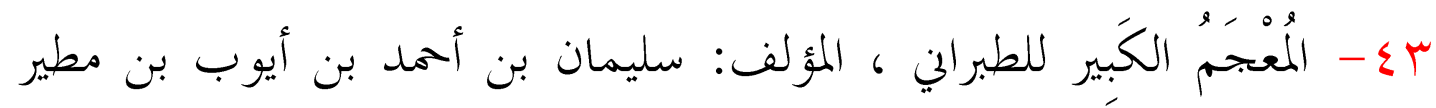

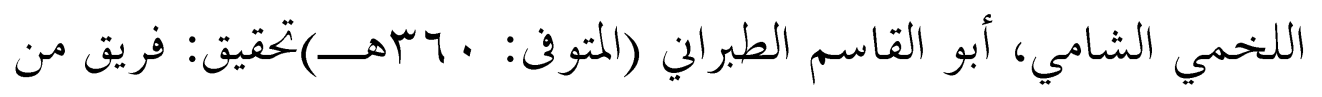

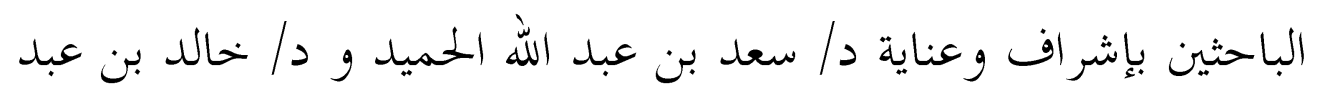
الرحمن الجريسي. ؟ع - مقدمة حول الاستشراق والمسشرقين ، موقف المدرسة العقلية من السنة النبوية.

0ـ - المعجم الوسيط ، المؤلف: بحمع اللغة العربية بالقاهرة (إبراهيم مصطفى / أحمد الزيات / حامد عبد القادر / محمد النجار) الناشر: دار الدعوة.

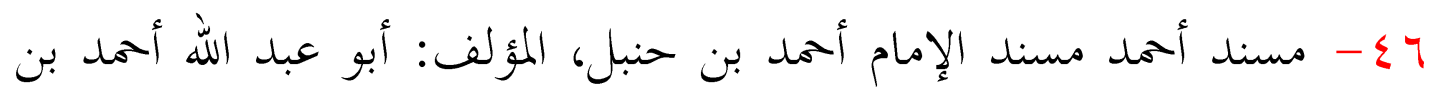
محمد بن حنبل بن هلال بن أسد الشيباني (المتوفى: إع بهـ)،المحقق:

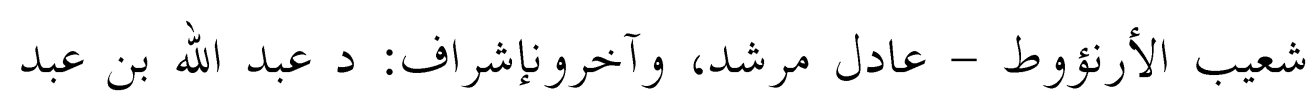

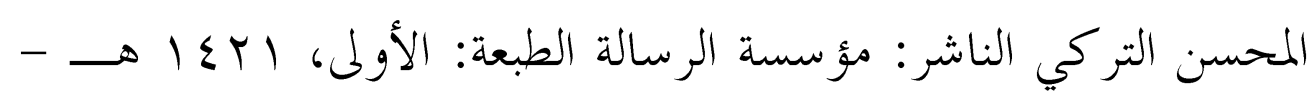
. $r$ r. ع V

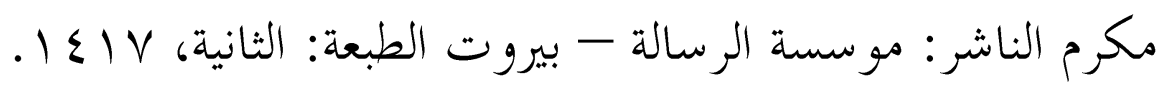


الدلالة اللغوية بين رقي القرآن وشبهات المستشرقين وجهلهم بإعجاز اللفظ القرآي.

^ی - المصباح المنير في غريب الشرح الكبير،المؤلف: أحمد بن محمد بن علي

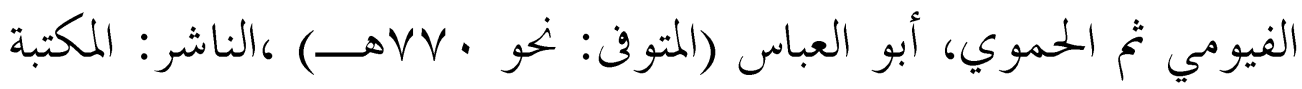

العلمية - بيروت.

ج) - نزهة الأعين النواظر في علم الوجوه و النظائر،المؤلف: جمال الدين أبو

الفرج عبد الرحمن بن علي بن محمد الجوزي (المتوف:

9 V Vهـ)، المحقق: محمد عبد الكريم كاظم الراضيكالناشر: مؤسسة

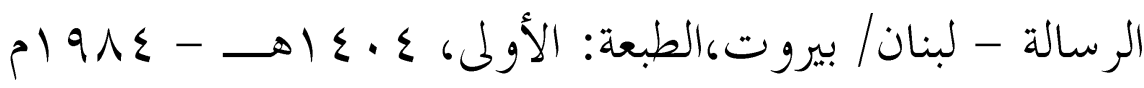

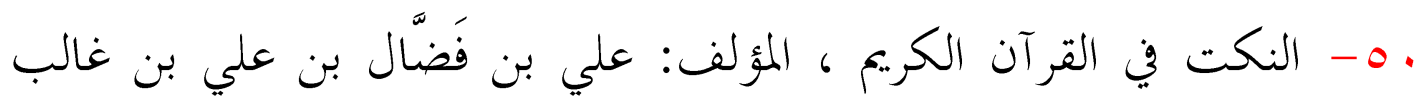

المُجَاشعي القيرواني، أبو الحسن (المتوفى: V9 Vهــ) ، دراسة و تحقيق: د.

عبد اللّ عبد القادر الطويل ، دار النشر: دار الكتب العلمية - بيروت ،

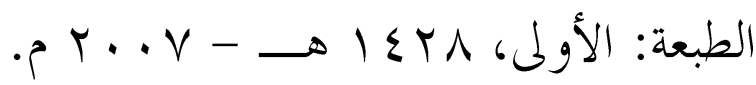

ا ه - الوجوه والنظائر لأبي هلال العسكري ، المؤلف: أبو هلال الحسن بن

عبد الله بن سهل بن سعيد بن ״يیى بن مهر ان العسكري (المتوفن: ثخو

هوبهـ) ، حققه وعلق عليه: محمد عثمان 6 الناشر: مكتبة الثقافة

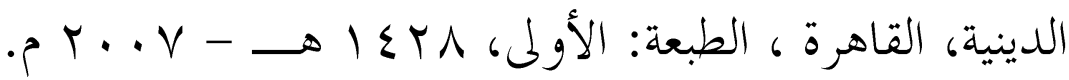

